Supporting Information for the Paper Entitled:

\title{
Synthesis of Silyl Aluminum Reagents: Relevance Towards Atomic Layer Deposition of Metal Silicides and the Serendipitous Synthesis of a Novel Al-Hydride Cluster
}

\author{
Roman Bashkurov, ${ }^{\mathrm{a}}$ Yosi Kratish, ${ }^{\mathrm{a}}$ Charles C. Mokhtarzadeh, ${ }^{*} \mathrm{~b}$ Natalia Fridman, ${ }^{\mathrm{a}}$ \\ Dmitry Bravo-Zhivotovskii, ${ }^{a}$ Patricio E. Romero, ${ }^{\text {bc }}$ Scott B. Clendenning, ${ }^{\text {b }}$ and Yitzhak \\ Apeloig* a \\ ${ }^{\text {a }}$ Schulich Faculty of Chemistry, Technion-Israel Institute of Technology, Haifa 32000 \\ Israel. \\ ${ }^{\mathrm{b}}$ Intel Corporation, 2501 NE Century Blvd., Hillsboro, Oregon, USA 97124. \\ ${ }^{\mathrm{c}}$ Current Address: Pontificia Universidad Católica de Chile, Escula de Ingenieria, Vicuna \\ Mackenna 4860, Macul Santiago, Chile.
}

Email: charles.mokhtarzadeh@intel.com; apeloig@technion.ac.il

\section{Contents}

1. Experimental - General Conditions.............................................................. 2

2. General Synthetic Procedure for $\left(\mathbf{R}_{3} \mathbf{S i}\right)_{2} \mathbf{H g}$ and $\mathbf{R}_{3} \mathrm{SiLi}$ Reagents ......................... 2

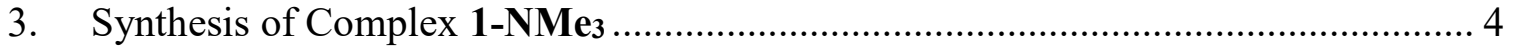

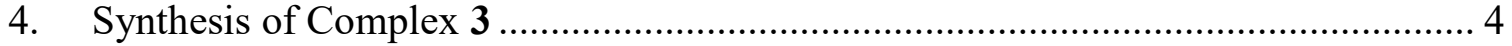

5. General Synthetic Procedure for Complexes 4-Cl, 5-Br and 6-Br ......................... 5

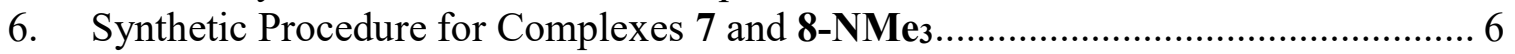

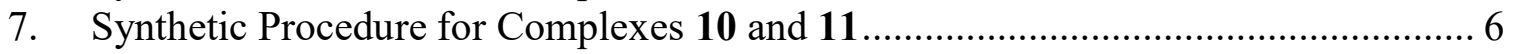

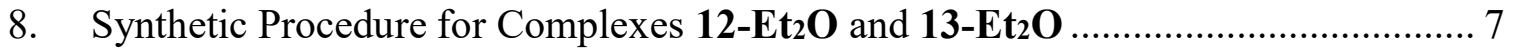

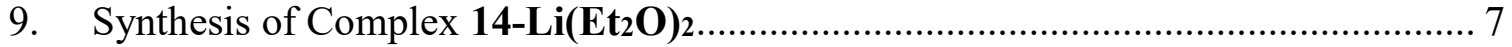

10. General Synthetic Procedure for Amine Coordinated Complexes 2-NMe3, 15-NMe3, 16-NMe, 1 17-NMe

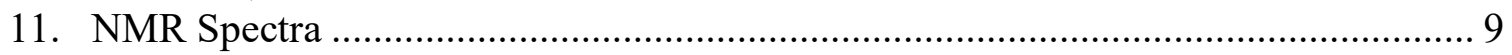

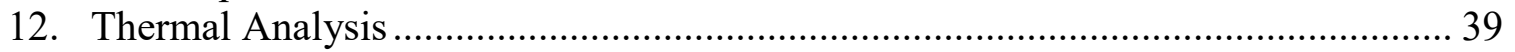

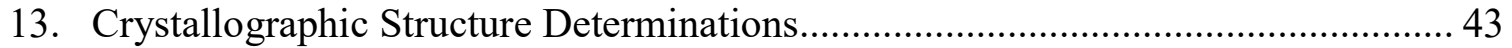

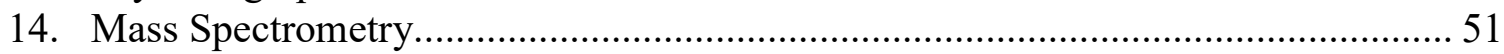

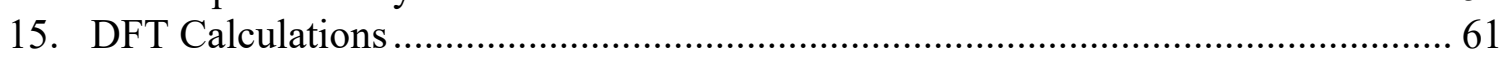

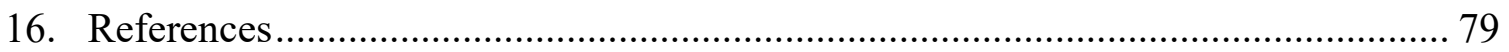




\section{Experimental - General Conditions}

All manipulations were carried out under an inert atmosphere of dry dinitrogen or argon using standard Schlenk techniques. Solvents were dried and kept over anhydrous $\mathrm{CaCl}_{2}$, filtered, degassed, stored over ${ }^{\mathrm{t}} \mathrm{BuLi}\left(\mathrm{Et}_{2} \mathrm{O}\right.$ was stored over $\mathrm{Ph}_{3} \mathrm{CLi}$ ) under vacuum and distilled prior to use. Liquid reagents were degassed according to standard procedures. ${ }^{1}$ Unless otherwise stated all materials were obtained from commercial vendors and used as received or purified by standard procedures. ${ }^{1}$ All NMR experiments were recorded in room temperature solutions of benzene $\left(\mathrm{C}_{6} \mathrm{H}_{6}\right)$, toluene $\left(\mathrm{C}_{7} \mathrm{H}_{8}\right)$, hexane $\left(\mathrm{C}_{6} \mathrm{H}_{14}\right)$ or diethyl ether $\left(\mathrm{Et}_{2} \mathrm{O}\right)$ in a resealable Young's vacuum NMR tubes equipped with DMSO- $d_{6}$ capillary as an external standard.

Solution ${ }^{1} \mathrm{H},{ }^{13} \mathrm{C}\left\{{ }^{1} \mathrm{H}\right\},{ }^{29} \mathrm{Si}\left\{{ }^{1} \mathrm{H}\right\}$ spectra were recorded using a Bruker Advance 500 or Bruker Advance 600 spectrometers. ${ }^{1} \mathrm{H}$ and ${ }^{13} \mathrm{C}$ chemical shifts are reported in ppm relative to $\mathrm{SiMe}_{4}\left({ }^{1} \mathrm{H}\right.$ and $\left.{ }^{13} \mathrm{C} \delta=0.0 \mathrm{ppm}\right)$ with reference to residual DMSO solvent resonance of $2.50 \mathrm{ppm}\left({ }^{1} \mathrm{H}\right)$ and $39.52 \mathrm{ppm}\left({ }^{13} \mathrm{C}\right) \cdot{ }^{2}{ }^{29} \mathrm{Si}$ chemical shifts were externally referenced to dilute TMS in $\mathrm{CDCl}_{3}$ at $0.0 \mathrm{ppm} .{ }^{3}$ The INEPT pulse sequence was used to enhance ${ }^{29} \mathrm{Si}$ NMR signals. ${ }^{4,5}$ If not stated otherwise, the NMR experiments were carried out ${ }^{1} \mathrm{H}$ decoupled.

Note: The ${ }^{27}$ Al NMR spectra were not measured for the silyl aluminum compounds. ${ }^{27} \mathrm{Al}$ has a spin 5/2 nucleus and is a quadrupolar resulting in broad ${ }^{27} \mathrm{Al} N \mathrm{NR}$ chemical shift signals which are not indicative. ${ }^{6,7}$ The ${ }^{29}$ Si NMR spectra were not measured as well. The quadrupole nature of the Al nuclei causes difficulties in ${ }^{29} \mathrm{Si} N \mathrm{MR}$ measurements (in contrast to its analogs like gallium). The ${ }^{29} \mathrm{Si}$ NMR signals are significantly broader than usual and require in most cases longer measurement times. Due to the broad ${ }^{29} \mathrm{Si} N \mathrm{NR}$ chemical shift signals, they are not indicative. Therefore, usually ${ }^{13} \mathrm{C}$ and ${ }^{1} \mathrm{H} N \mathrm{MR}$ are used for characterization of organosilicon aluminum compounds.

High resolution mass spectrometry (HRMS) measurements were performed on a Bruker Maxis Impact mass spectrometer using APCI (Atmospheric Pressure Chemical Ionization) technique in either positive or negative ion mode. ${ }^{8}$ Nitrogen was used as both nebulizer $(0.16 \mathrm{MPa})$ and drying $\left(4.0 \mathrm{~L} \mathrm{~min}^{-1}\right)$ gases. The temperature of the APCI heater was $250{ }^{\circ} \mathrm{C}$ of the drying heater. The corona discharge current was $2 \mu \mathrm{A}$. Note: With the APCI technique $[\mathrm{M}+\mathrm{H}]^{+}$peaks are often observed instead of $\mathrm{M}^{+} .8 \mathrm{~b}$

\section{General Synthetic Procedure for $\left(\mathrm{R}_{3} \mathrm{Si}\right)_{2} \mathrm{Hg}$ and $\mathrm{R}_{3} \mathrm{SiLi}$ Reagents}

A $250 \mathrm{ml}$ Schlenk flask was charged with $50 \mathrm{~g}(0.159 \mathrm{~mol})$ of ${ }^{\mathrm{t}} \mathrm{Bu}_{2} \mathrm{Hg}^{9}$ dissolved in 5 equivalents of a silane $(0.795 \mathrm{~mol})$ and was heated for 1 week at $120{ }^{\circ} \mathrm{C}$ affording $\mathrm{Hg}\left(\mathrm{SiR}_{3}\right)_{2}$ in yields averaging $50 \%$. The remaining silane was removed from the reaction mixture by vacuum transfer distillation $\left(0.2\right.$ Torr, $\left.40{ }^{\circ} \mathrm{C}\right)$ and is pure enough for reuse in subsequent $\mathrm{Hg}\left(\mathrm{SiR}_{3}\right)_{2}$ syntheses. The purified $\left(\mathrm{R}_{3} \mathrm{Si}\right)_{2} \mathrm{Hg}$ was dissolved in hexane $(200 \mathrm{ml})$ 
and transferred to a Schlenk flask containing $4.5 \mathrm{~g}$ of metallic ground lithium $\left(\mathrm{Li}^{\circ}\right)$. It is important to use finally dispersed $\mathrm{Li}^{\circ}$ metal and so small chips were prepared by grinding a lithium stick with a file under an argon atmosphere.

Note: The quality of the lithium metal can affect the lithiation rate; highly pure Li does not react at room temperature and requires sonication and heating at $100^{\circ} \mathrm{C}$ for $1 \mathrm{~h}$ in order to obtain $\mathrm{R}_{3} \mathrm{SiLi}$ in $95 \%$ yield, however, this also leads to the formation of a very dispersed $L i^{\circ}$ metal particles which are difficult to separate. $\mathrm{Li}^{\circ}$ containing $1 \%$ of $\mathrm{Na}{ }^{\circ}$ reacts at room temperature overnight yielding a clear solution of $R_{3} \mathrm{SiLi}$ in $\geq 95 \%$ yield. The hexane mixture, containing the silyl lithium, was separated from the Li metal chips by decantation. To verify the formation of $\mathrm{R}_{3} \mathrm{SiLi}$, addition of $\mathrm{D}_{2} \mathrm{O}$ to a small aliquot of the reaction mixture and analysis by ${ }^{1} \mathrm{H}$ NMR indicated quantitative conversation to $\mathrm{R}_{3} \mathrm{SiD}$, validating the presence of silyl lithium.

Safety note: Alkyl and silyl mercury compounds are generally toxic. Dermal contact and inhalation must be avoided. Proper disposal procedures as hazardous waste must be followed. ${ }^{10}$ However, it should be emphasized that the general hazard of working with mercury compounds is probably reduced significantly with our silyl compounds, due to their low volatility. In addition, the silyl mercury compounds used in this paper are quickly oxidized in air, yielding $\mathrm{Hg}(0)$ and non-toxic organosilanols and/or siloxanes.

NMR of ( $\left.{ }^{\mathrm{t}} \mathrm{BuMe} 2 \mathrm{Si}\right)_{2} \mathrm{Hg}$ (in benzene with a DMSO- $d_{6}$ capillary, $25^{\circ} \mathrm{C}, 600 \mathrm{MHz}$ ), $\delta$ in ppm:

${ }^{1} \mathrm{H}: \delta=0.24$ (s, 12H, MeSi), 1.04 (s, 18H, $\left.{ }^{\mathrm{t}} \mathrm{BuSi}\right) ;{ }^{13} \mathrm{C}: \delta=0.67$ (MeSi), 28.12 ('BuSi);

${ }^{29} \mathrm{Si}: \delta=75.7(\mathrm{Si}-\mathrm{Hg})$.

HRMS (APCI positive ion; n-hexane): $\mathrm{m} / \mathrm{z}$ calc. for $\mathrm{C}_{12} \mathrm{H}_{30} \mathrm{HgSi}_{2}$ : 432.1586. Found: $432.1649[\mathrm{M}]^{+}$.

NMR of $\left(\mathbf{E t}_{3} \mathrm{Si}\right){ }_{2} \mathbf{H g}$ (in benzene with a DMSO- $d_{6}$ capillary, $\left.25^{\circ} \mathrm{C}, 600 \mathrm{MHz}\right), \delta$ in ppm: ${ }^{1} \mathrm{H}: \delta=0.93\left(\mathrm{q}, 12 \mathrm{H}, 7.69 \mathrm{~Hz}, \mathrm{CH}_{2}\right), 1.12\left(\mathrm{t}, 18 \mathrm{H}, 7.69 \mathrm{~Hz}, \mathrm{CH}_{3}\right) ;{ }^{13} \mathrm{C}: \delta=8.99\left(\mathbf{C H}_{2}\right)$, $10.51\left(\mathrm{CH}_{3}\right) ;{ }^{29} \mathrm{Si}: \delta=79.1(\mathrm{Si}-\mathrm{Hg})$.

HRMS (APCI positive ion; n-hexane): m/z calc. for $\mathrm{C}_{12} \mathrm{H}_{30} \mathrm{HgSi}_{2}+\mathrm{H}$ : 433.1664. Found: 433.2784 $[\mathrm{M}+\mathrm{H}]^{+}$.

NMR of ${ }^{\mathrm{t}} \mathrm{BuMe} 2 \mathrm{SiLi}$ (in benzene with a DMSO- $d_{6}$ capillary, $25^{\circ} \mathrm{C}, 600 \mathrm{MHz}$ ), $\delta$ in ppm: ${ }^{1} \mathrm{H}: \delta=0.15(\mathrm{~s}, 6 \mathrm{H}, \mathrm{MeSi}), 1.00\left(\mathrm{~s}, 9 \mathrm{H},{ }^{\mathrm{t}} \mathrm{BuSi}\right) ;{ }^{13} \mathrm{C}: \delta=-0.25(\mathrm{MeSi}), 28.168\left({ }^{\mathrm{t}} \mathrm{BuSi}\right){ }^{29} \mathrm{Si}:$ $\delta=-23.0(\mathbf{S i}-\mathrm{Li})$.

HRMS (APCI positive ion; n-hexane): An ion peak of ${ }^{\mathbf{t}} \mathbf{B u M e 2 S i L i}$ interacting with nebulizer $\mathrm{N}_{2}$ was detected; $\mathrm{m} / \mathrm{z}$ calc. for $\mathrm{C}_{6} \mathrm{H}_{15} \mathrm{LiSi}-\mathrm{H}+\mathrm{N}_{2}$ : 149.1081. Found: 149.0463 $\left[\mathrm{M}-\mathrm{H}+\mathrm{N}_{2}\right]^{+}$.

NMR of Et 3 SiLi (in hexane with a DMSO- $d_{6}$ capillary, $25^{\circ} \mathrm{C}, 600 \mathrm{MHz}$ ), $\delta$ in ppm: 
${ }^{1} \mathrm{H}: \delta=0.64\left(\mathrm{q}, 12 \mathrm{H}, 7.69 \mathrm{~Hz}, \mathrm{CH}_{2}\right), 1.02\left(\mathrm{t}, 18 \mathrm{H}, 7.69 \mathrm{~Hz}, \mathrm{CH}_{3}\right) ;{ }^{13} \mathrm{C}: \delta=8.19\left(\mathbf{C H}_{2}\right), 9.80$ $\left(\mathrm{CH}_{3}\right) ;{ }^{29} \mathrm{Si}: \delta=-12.7(\mathbf{S i}-\mathrm{Hg})$.

HRMS (APCI positive ion; n-hexane): An ion peak of a dimer of $\mathbf{E t}_{3} \mathbf{S i L i}$ was detected; $\mathrm{m} / \mathrm{z}$ calc. for $\left(\mathrm{C}_{6} \mathrm{H}_{15} \mathrm{LiSi}\right)_{2}+\mathrm{H}: 245.2279$. Found: $245.1864\left[\mathrm{M}_{2}+\mathrm{H}\right]^{+}$.

NMR of ${ }^{\mathrm{t}} \mathrm{BuMe} \mathrm{e}_{2} \mathrm{SiD}$ (in benzene with a DMSO- $d_{6}$ capillary, $25^{\circ} \mathrm{C}, 600 \mathrm{MHz}$ ), $\delta$ in ppm: ${ }^{1} \mathrm{H}: \delta=-0.01(\mathrm{~s}, 6 \mathrm{H}, \mathrm{MeSi}) ; 0.91\left(\mathrm{~s}, 9 \mathrm{H},{ }^{\mathrm{t}} \mathrm{BuSi}\right) ;{ }^{13} \mathrm{C}: \delta=-7.71(\mathrm{MeSi}), 26.00\left({ }^{\mathrm{t}} \mathrm{BuSi}\right) ;{ }^{29} \mathrm{Si}$ : $\delta=-2.51(\mathrm{t}, 27.63 \mathrm{~Hz}, \mathrm{Si}-\mathrm{D})$.

HRMS (APCI positive ion; $n$-hexane): $\mathrm{m} / \mathrm{z}$ calc. for $\mathrm{C}_{6} \mathrm{H}_{15} \mathrm{DSi}$ : 117.1079. Found: $117.0846[\mathrm{M}]^{+}$.

NMR of Et $\mathbf{E t}_{3} \mathrm{SiD}$ (in hexane with a DMSO- $d_{6}$ capillary, $25^{\circ} \mathrm{C}, 600 \mathrm{MHz}$ ), $\delta$ in ppm:

${ }^{1} \mathrm{H}: \delta=0.56\left(\mathrm{q}, 6 \mathrm{H}, 8.05 \mathrm{~Hz}, \mathrm{CH}_{2}\right), 0.95(\mathrm{t}, 9 \mathrm{H}, 8.05 \mathrm{~Hz}, \mathrm{CH}) ;{ }^{13} \mathrm{C}: \delta=2.13\left(\mathbf{C H}_{2}\right), 7.45$ $\left(\mathrm{CH}_{3}\right) ;{ }^{29} \mathrm{Si}: \delta=-0.64(\mathrm{t}, 27.92 \mathrm{~Hz}, \mathrm{Si}-\mathrm{D})$.

HRMS (APCI positive ion; $n$-hexane): $\mathrm{m} / \mathrm{z}$ calc. for $\mathrm{C}_{6} \mathrm{H}_{15} \mathrm{DSi}$ : 117.1079. Found: $117.0766[\mathrm{M}]^{+}$.

\section{Synthesis of Complex 1-NMe3}

To an $\mathrm{Et}_{2} \mathrm{O}$ solution $(30 \mathrm{ml})$ of $\mathrm{AlCl}_{3}(0.66 \mathrm{gr}, 5 \mathrm{mmol})$ at $-78^{\circ} \mathrm{C}{ }^{\mathrm{t}} \mathrm{BuMe}{ }_{2} \mathrm{SiLi}(1.83 \mathrm{gr}, 15$ $\mathrm{mmol})$ in $\mathrm{Et}_{2} \mathrm{O}(15 \mathrm{~mL})$ was added stepwise in 2 portions. After each addition, the temperature was raised to room temperature and the reaction was stirred for 30 mins. Addition of excess $\mathrm{NMe}_{3}$ ( $\sim 10$ equivalents) to the reaction mixture followed by removal of all volatiles under reduced pressure ( 0.2 Torr $)$ at room temperature led to a mixture of 1$\mathrm{NMe}_{3}$ and 2-NMe 3 in approximately 1:1 ratio as assayed by ${ }^{1} \mathrm{H}$ NMR spectroscopy. 1NMe 3 was separated from the reaction mixture by sublimation at $100^{\circ} \mathrm{C}(0.2$ Torr $)$ or by crystallization at room temperature from hexane $(0.47 \mathrm{gr}, 35 \%)$.

NMR of 1-NMe 3 (in $\mathrm{Et}_{2} \mathrm{O}$ with a DMSO- $d_{6}$ capillary, $25^{\circ} \mathrm{C}, 600 \mathrm{MHz}$ ), $\delta$ in ppm: ${ }^{1} \mathrm{H}: \delta=0.05$ (s, 6H, MeSi), 1.03 (s, 9H, $\left.{ }^{\mathrm{t}} \mathrm{BuSi}\right), 2.69\left(\mathrm{~s}, 9 \mathrm{H}, \mathrm{Me}_{3} \mathrm{~N}\right) ;{ }^{13} \mathrm{C}: \delta=-4.35(\mathrm{MeSi})$, 27.99 ('BuSi), $46.10\left(\mathbf{M e}_{3} \mathrm{~N}\right)$.

HRMS (APCI positive ion; n-hexane): m/z calc. for $\mathrm{C}_{9} \mathrm{H}_{24} \mathrm{AlCl}_{2} \mathrm{NSi}+\mathrm{H}: 272.0943$. Found: $272.2412[\mathrm{M}+\mathrm{H}]^{+}$.

\section{Synthesis of Complex 3}

An $\mathrm{Et}_{2} \mathrm{O}$ solution $(10 \mathrm{ml})$ of $\mathrm{Me}_{2} \mathrm{~N}\left(\mathrm{CH}_{2}\right)_{3}\left(\mathrm{tBuMe}_{2} \mathrm{Si}_{2} \mathrm{SiLi}^{11}(0.66 \mathrm{gr}, 1.88 \mathrm{mmol})\right.$ was added to an $\mathrm{Et}_{2} \mathrm{O}$ solution $(10 \mathrm{ml})$ of $\mathrm{AlCl}_{3}(0.20 \mathrm{gr}, 1.5 \mathrm{mmol})$ at $0{ }^{\circ} \mathrm{C}$. The temperature was raised to room temperature and the reaction was stirred for $30 \mathrm{mins}$. All the volatiles 
were removed under reduced pressure $(0.2$ Torr) at room temperature followed by the addition of fresh hexane $(30 \mathrm{ml})$. To separate the solution from the precipitated salt, the mixture was decanted. Concentration of the hexane solution yielded colorless crystals $(0.25$ gr, $38 \%)$ of 3 .

NMR of 3 (in benzene with a DMSO- $d_{6}$ capillary, $25^{\circ} \mathrm{C}, 600 \mathrm{MHz}$ ), $\delta$ in ppm:

${ }^{1} \mathrm{H}: \delta=0.58,0.62(\mathrm{~s}, 12 \mathrm{H}, \mathbf{M e S i}), 1.32\left(\mathrm{~s}, 18 \mathrm{H},{ }^{\mathrm{t}} \mathrm{BuSi}\right), 0.77\left(\mathrm{~m}, 2 \mathrm{H}, \mathrm{CH}_{2}\right), 2.10(\mathrm{~m}, 2 \mathrm{H}$, $\left.\mathrm{CH}_{2}\right), 2.51\left(\mathrm{~m}, 2 \mathrm{H}, \mathrm{CH}_{2}\right), 2.51\left(\mathrm{~s}, 6 \mathrm{H}, \mathbf{M e}_{2} \mathrm{~N}\right) \cdot{ }^{13} \mathrm{C}: \delta=-2.33,-1.97(\mathrm{MeSi}), 28.05$ ( $\left.{ }^{\mathrm{t}} \mathrm{BuSi}\right), 6.01\left(\mathrm{CH}_{2}\right), 18.80\left(\mathrm{CH}_{2}\right), 30.03\left(\mathbf{C H}_{2}\right), 42.14\left(\mathbf{M e}_{2} \mathrm{~N}\right) .{ }^{29} \mathrm{Si}: \delta=0.96\left({ }^{\mathrm{t}} \mathrm{BuMe}_{2} \mathbf{S i}\right)$. HRMS: we did not observe an ion peak for 3; probably due to its low thermal stability.

\section{General Synthetic Procedure for Complexes 4-Cl, 5-Br and 6-Br}

To an $\mathrm{Et}_{2} \mathrm{O}$ solution $(30 \mathrm{ml})$ of $\mathrm{AlX}_{3}(\mathrm{X}=\mathrm{Cl}, \mathrm{Br})(5 \mathrm{mmol})$ at $-78^{\circ} \mathrm{C}$ was added a hexane solution of $\mathrm{R}_{3} \mathrm{SiLi}\left(\mathrm{R}_{3} \mathrm{Si}=\mathrm{tBuMe}_{2} \mathrm{Si}_{2} \mathrm{Et}_{3} \mathrm{Si}\right)(10 \mathrm{mmol}, 10 \mathrm{ml})$ stepwise in 2 portions. After each addition the temperature was raised to r.t and the reaction was stirred for $30 \mathrm{~min}$. Upon completion and stirring at room temperature, all volatiles were removed under reduced pressure $(0.2$ Torr) at room temperature followed by the addition of fresh hexane $(60 \mathrm{ml})$. To separate the solution from the precipitated salt, the mixture was decanted. Removal of all volatiles under reduced pressure $(0.2$ Torr $)$ with heating to $100^{\circ} \mathrm{C}$ yielded colorless crystals of 4-Cl (1.19 gr, 76\%) and 5-Br (1.31 gr, 73\%) and semi-crystalline oil for $6-\mathrm{Br}(1.03 \mathrm{gr}, 69 \%)$.

NMR of 4-Cl (in toluene with a DMSO- $d_{6}$ capillary, $25^{\circ} \mathrm{C}, 600 \mathrm{MHz}$ ), $\delta$ in ppm:

${ }^{1} \mathrm{H}: \delta=0.49$ (s, 24H, MeSi), 1.28 (s, 36H, $\left.{ }^{\mathrm{t}} \mathrm{BuSi}\right) ;{ }^{13} \mathrm{C}: \delta=-3.95(\mathrm{MeSi}) ; 27.81\left({ }^{\mathrm{t}} \mathrm{BuSi}\right)$.

HRMS (APCI positive ion; n-hexane): $\mathrm{m} / \mathrm{z}$ calc. for $\mathrm{C}_{12} \mathrm{H}_{30} \mathrm{AlClSi}_{2}-\mathrm{H}: 291.1306$. Found: $291.1590[\mathrm{M}-\mathrm{H}]^{+}$.

NMR of 5-Br (in $\mathrm{Et}_{2} \mathrm{O}$ with a DMSO- $d_{6}$ capillary, $25^{\circ} \mathrm{C}, 600 \mathrm{MHz}$ ), $\delta$ in ppm:

${ }^{1} \mathrm{H}: \delta=0.18$ (s, 24H, MeSi), 1.1 (s, 36H, $\left.{ }^{\mathrm{t}} \mathrm{BuSi}\right) ;{ }^{13} \mathrm{C}: \delta=-3.67(\mathrm{MeSi}), 28.05\left({ }^{\mathrm{t}} \mathrm{BuSi}\right)$.

HRMS (APCI negative ion; $n$-hexane): $\mathrm{m} / \mathrm{z}$ calc. for $\mathrm{C}_{12} \mathrm{H}_{30} \mathrm{AlBrSi}_{2}: 337.0781$. Found: $336.8572[\mathrm{M}]^{-}$.

NMR of 6-Br (in Et $2 \mathrm{O} /$ hexane with a DMSO- $d_{6}$ capillary, $25^{\circ} \mathrm{C}, 600 \mathrm{MHz}$ ), $\delta$ in ppm:

${ }^{1} \mathrm{H}: \delta=0.64\left(\mathrm{q}, 12 \mathrm{H}, 7.91 \mathrm{~Hz}, \mathrm{CH}_{2}\right) ; 0.99(\mathrm{t}, 18 \mathrm{H}, 7.91 \mathrm{~Hz}, \mathrm{CH}) ;{ }^{13} \mathrm{C}: \delta=4.61\left(\mathbf{C H}_{2}\right)$, $8.48\left(\mathrm{CH}_{3}\right)$.

HRMS (APCI positive ion; n-hexane): An ion peak of a monomer of 6-Br coordinated with $\mathrm{Et}_{2} \mathrm{O}$ was detected; $\mathrm{m} / \mathrm{z}$ calc. for $\mathrm{C}_{12} \mathrm{H}_{30} \mathrm{AlBrSi}_{2}+\mathrm{Et}_{2} \mathrm{O}+\mathrm{H}$ : 411.1514. Found: $411.3996\left[\mathrm{M}+\mathrm{Et}_{2} \mathrm{O}+\mathrm{H}\right]^{+}$. 


\section{Synthetic Procedure for Complexes 7 and 8-NMe3}

To an $\mathrm{Et}_{2} \mathrm{O}$ solution $(2 \mathrm{ml})$ of $\mathbf{5 - B r}(0.47 \mathrm{gr}, 1.4 \mathrm{mmol})$ at $0^{\circ} \mathrm{C}$ was added an $\mathrm{Et}_{2} \mathrm{O}$ solution $(1.5 \mathrm{ml})$ of $\mathrm{MeLi}(0.03 \mathrm{gr}, 1.4 \mathrm{mmol})$ in 3 portions. After each addition the reaction mixture was heated in a sonication bath for $2 \mathrm{~h}$ at $60^{\circ} \mathrm{C}$. Upon completion, all volatiles were removed under reduced pressure ( 0.2 Torr) at room temperature and fresh hexane $(10 \mathrm{ml})$ was added. To separate the solution from the precipitated salt, the mixture was decanted. Removal of the volatiles under reduced pressure (0.2 Torr) yielded 7 ( $0.24 \mathrm{gr}, 51 \%)$. Addition of $\mathrm{NMe}_{3}(\sim 10$ equivalents) to 7 followed by removal of the excessive amine led to the formation of $8-\mathrm{NMe}_{3}(0.22 \mathrm{gr}, 94 \%)$.

NMR of 7 (in $\mathrm{Et}_{2} \mathrm{O}$ with a DMSO- $d_{6}$ capillary, $25^{\circ} \mathrm{C}, 500 \mathrm{MHz}$ ), $\delta$ in ppm:

${ }^{1} \mathrm{H}: \delta=-0.45$ (s, 3H, MeAl), -0.02 (s, 12H, MeSi), 0.88 (s, $\left.18 \mathrm{H},{ }^{\mathrm{t}} \mathrm{BuSi}\right) ;{ }^{13} \mathrm{C}: \delta=-5.47$ (MeAl), -2.80 (MeSi), 28.07 ('BuSi).

HRMS (APCI positive ion; n-hexane): m/z calc. for $\mathrm{C}_{13} \mathrm{H}_{33} \mathrm{AlSi}_{2}+\mathrm{H}$ : 273.2009. Found: $273.2035[\mathrm{M}+\mathrm{H}]^{+}$.

NMR of 8-NMe 3 (in hexane with a DMSO- $d_{6}$ capillary, $25^{\circ} \mathrm{C}, 500 \mathrm{MHz}$ ), $\delta$ in ppm:

${ }^{1} \mathrm{H}: \delta=-0.51$ (s, 3H, MeAl), -0.01 (s, 6H, MeSi), 0.02 (s, 6H, MeSi), 0.89 (s, 18H, 'BuSi), $2.50\left(\mathrm{~s}, 9 \mathrm{H}, \mathrm{Me}_{3} \mathrm{~N}\right) ;{ }^{13} \mathrm{C}: \delta=-1.83,-1.40(\mathrm{MeSi}), 27.96\left({ }^{\mathrm{t}} \mathrm{BuSi}\right), 49.17\left(\mathrm{Me}_{3} \mathrm{~N}\right)$.

HRMS (APCI positive ion; n-hexane): m/z calc. for $\mathrm{C}_{16} \mathrm{H}_{42} \mathrm{AlNSi}_{2}$ : 331.2666. Found: $331.2324[\mathrm{M}]^{+}$.

\section{Synthetic Procedure for Complexes 10 and 11}

To an $\mathrm{Et}_{2} \mathrm{O}(10 \mathrm{ml})$ solution of $\mathbf{5}-\mathrm{Br}(0.41 \mathrm{gr}, 0.58 \mathrm{mmol})$ at $-78^{\circ} \mathrm{C}$, an $\mathrm{Et}_{2} \mathrm{O}$ solution of $\mathrm{LiAlH}_{4}(1.20 \mathrm{mmol}, 3 \mathrm{ml}, 0.4 \mathrm{M})$ was added stepwise in 2 portions. After each addition the temperature was raised to room temperature and the reaction was stirred for $30 \mathrm{~min}$. Following, all the volatiles were removed under reduced pressure $(0.2$ Torr $)$ at room temperature and fresh hexane $(20 \mathrm{ml})$ was added. To separate the solution from the precipitated salt, the mixture was decanted. Removal of the volatiles under reduced pressure (0.2 Torr) at room temperature yielded colorless crystals of $\mathbf{1 0}(0.24 \mathrm{gr}, 73 \%)$. Addition of TMEDA ( $\sim 10$ equivalents) to $\mathbf{1 0}$ followed by removal of the excessive amine led to the formation of colorless crystals of 11 (0.053 gr, 27\%).

NMR of 10 (in hexane with a DMSO- $d_{6}$ capillary, $25^{\circ} \mathrm{C}, 600 \mathrm{MHz}$ ), $\delta$ in ppm:

${ }^{1} \mathrm{H}: \delta=0.10$ (s, 36H, MeSi), 0.16 (s, 36H, MeSi), 0.92 (s, 54H, ${ }^{\mathbf{B u S i}}$ ), 0.97 (s, 54H, 'BuSi);

${ }^{13} \mathrm{C}: \delta=-3.36,-3.17$ (MeSi), 27.72, 27.79 ('BuSi). 
HRMS (APCI positive ion; n-hexane): An ion peak of a monomer [( $\left.{ }^{\mathrm{t}} \mathrm{BuMe}{ }_{2} \mathrm{Si}\right)_{2} \mathrm{Al}(\mu-$ H) $\left.\mathrm{AlH}_{3}\right]$ of $\mathbf{1 0}$ was detected; m/z calc. for $\mathrm{C}_{12} \mathrm{H}_{34} \mathrm{Al}_{2} \mathrm{Si}_{2}+\mathrm{H}$ : 289.1903. Found: 289.2367 $[\mathrm{M}+\mathrm{H}]^{+}$.

NMR of 11 (in toluene with a DMSO- $d_{6}$ capillary, $25^{\circ} \mathrm{C}, 600 \mathrm{MHz}$ ), $\delta$ in ppm:

${ }^{1} \mathrm{H}: \delta=0.15,0.29$ (s, 24H, MeSi), 1.14 (s, 36H, $\left.{ }^{\mathrm{t}} \mathrm{BuSi}\right) ;{ }^{13} \mathrm{C}: \delta=-1.55(\mathrm{MeSi}), 27.63$ ('BuSi), $45.04\left(\mathbf{M e}_{2} \mathrm{~N}\right)$.

HRMS: we did not observe an ion peak for 11, probably due to its high polarity and low volatility.

\section{Synthetic Procedure for Complexes 12-Et $2 \mathrm{O}$ and 13-Et $2 \mathrm{O}$}

To an $\mathrm{Et}_{2} \mathrm{O}$ solution $(30 \mathrm{ml})$ of $\mathrm{AlX}_{3}(\mathrm{X}=\mathrm{Cl}, \mathrm{Br})(5 \mathrm{mmol})$ at $-78^{\circ} \mathrm{C} \mathrm{Et}_{2} \mathrm{O}$ was added a solution of $\mathrm{R}_{3} \mathrm{SiLi}\left(\mathrm{R}_{3} \mathrm{Si}={ }^{\mathrm{t}} \mathrm{BuMe} \mathrm{Si}_{2} \mathrm{Si} \mathrm{Et}_{3} \mathrm{Si}\right)(15 \mathrm{mmol}, 15 \mathrm{ml})$ stepwise in 3 portions. After each addition the temperature was raised to room temperature and the mixture was stirred for $30 \mathrm{~min}$. Following mixing at room temperature all volatiles were removed under reduced pressure ( 0.2 Torr) at room temperature followed by the addition of fresh hexane $(60 \mathrm{ml})$. To separate the solution from the precipitated salt, the mixture was decanted. Removal of the volatiles under low pressure $(0.2$ Torr) at room temperature resulted in the formation of colorless crystals of 12-Et $\mathbf{t}_{2} \mathbf{O}(1.77 \mathrm{gr}, 82 \%)$ and semi-crystalline oil for 13$\mathbf{E t}_{2} \mathbf{O}(1.68$ gr, $78 \%)$.

NMR of 12-Et $\mathbf{t}_{2} \mathrm{O}$ (in hexane with a DMSO- $d_{6}$ capillary, $25^{\circ} \mathrm{C}, 600 \mathrm{MHz}$ ), $\delta$ in ppm: ${ }^{1} \mathrm{H}: \delta=0.10$ (s, 18H, MeSi). 0.94 (s, 27H, $\left.{ }^{\mathrm{t}} \mathrm{BuSi}\right) ;{ }^{13} \mathrm{C}: \delta=-1.08$ (MeSi), 28.7 ('BuSi).

HRMS (APCI positive ion; n-hexane): An ion peak of 12-Et $\mathbf{t}_{2} \mathbf{O}$ without coordination of $\mathrm{Et}_{2} \mathrm{O}$ was detected; $\mathrm{m} / \mathrm{z}$ calc. for $\mathrm{C}_{18} \mathrm{H}_{45} \mathrm{AlSi}_{3}-\mathrm{Et}_{2} \mathrm{O}-\mathrm{H}: 371.2511$. Found: 371.3217 [M $\left.\mathrm{Et}_{2} \mathrm{O}-\mathrm{H}\right]^{+}$.

NMR of 13-Et ${ }_{2} \mathrm{O}$ (in $\mathrm{Et}_{2} \mathrm{O} /$ hexane with a DMSO- $d_{6}$ capillary, $25^{\circ} \mathrm{C}, 500 \mathrm{MHz}$ ), $\delta$ in ppm: ${ }^{1} \mathrm{H}: \delta=0.62\left(\mathrm{q}, 18 \mathrm{H}, 7.78 \mathrm{~Hz}, \mathrm{CH}_{2}\right), 0.97\left(\mathrm{t}, 27 \mathrm{H}, 7.91 \mathrm{~Hz}, \mathrm{CH}_{3}\right) ;{ }^{13} \mathrm{C}: \delta=6.29\left(\mathbf{C H}_{2}\right)$, $8.98\left(\mathrm{CH}_{3}\right)$.

HRMS (APCI positive ion; n-hexane): $\mathrm{m} / \mathrm{z}$ calc. for $\mathrm{C}_{22} \mathrm{H}_{55} \mathrm{AlOSi}_{3}$ - H: 445.3292. Found: $445.3229[\mathrm{M}-\mathrm{H}]^{+}$.

\section{Synthesis of Complex 14-Li( $\left.\operatorname{Et}_{2} O\right)_{2}$}

To an $\mathrm{Et}_{2} \mathrm{O}$ solution $(30 \mathrm{ml})$ of $\mathrm{AlX}_{3}(\mathrm{X}=\mathrm{Cl}, \mathrm{Br})(5 \mathrm{mmol})$ at $-78^{\circ} \mathrm{C}$ was added an $\mathrm{Et}_{2} \mathrm{O}$ solution $(20 \mathrm{~mL})$ of ${ }^{\mathrm{t}} \mathrm{BuMe} 2 \mathrm{SiLi}(2.44 \mathrm{gr}, 20 \mathrm{mmol})$ stepwise in 4 portions. After each addition the temperature was raised to room temperature and allowed to stir for 30 mins. Upon warming to room temperature and stirring for 30 mins. After the final addition all 
volatiles were removed under reduced pressure $(0.2$ Torr) at room temperature and fresh hexane $(60 \mathrm{ml})$ was added. To separate the solution from the precipitated salt, the mixture was decanted. Removal of the volatiles under reduced pressure $(0.2$ Torr $)$ at room temperature yielded colorless crystals of $14-\mathbf{L i}\left(\mathbf{E t}_{2} \mathbf{O}\right)_{2}(1.73 \mathrm{gr}, 54 \%)$.

NMR of 14- $\mathbf{L i}\left(\mathbf{E t}_{2} \mathbf{O}\right)_{2}$ (in $\mathrm{Et}_{2} \mathrm{O}$ with a DMSO- $d_{6}$ capillary, $25^{\circ} \mathrm{C}, 500 \mathrm{MHz}$ ), $\delta$ in ppm: ${ }^{1} \mathrm{H}: \delta=0.01$ (s, 24H, MeSi), 0.89 (s, 36H, $\left.{ }^{\mathrm{t}} \mathrm{BuSi}\right) ;{ }^{13} \mathrm{C}: \delta=1.66$ (MeSi), 29.40 ('BuSi).

HRMS (APCI negative ion; n-hexane): $\mathrm{m} / \mathrm{z}$ calc. for $\mathrm{C}_{32} \mathrm{H}_{80} \mathrm{AlLiO}_{2} \mathrm{Si}_{4}$ : 642.5206. Found: $642.4532[\mathrm{M}]^{-}$.

\section{General Synthetic Procedure for Amine Coordinated Complexes 2-NMe3, 15- $\mathrm{NMe}_{3}, 16-\mathrm{NMe}_{3}, 17-\mathrm{NMe}_{3}$}

To a hexane solution of the desired aluminum complex, excess ( $\sim 10$ equivalents) of $\mathrm{NMe}_{3}$ was added. Removal of the volatiles under reduced pressure ( 0.2 Torr $)$ at room temperature yielded colorless crystals of 2-NMe 3 (1.25 gr, 94\%), 15-NMe 3 (1.33 gr, 92\%) and 16$\mathbf{N M e}_{3}$ (1.56 gr, 91\%) and semi-crystalline oil for 17-NMe $(1.49 \mathrm{gr}, 89 \%)$.

NMR of 2-NMe 3 (in hexane with a DMSO- $d_{6}$ capillary, $25^{\circ} \mathrm{C}, 600 \mathrm{MHz}$ ), $\delta$ in ppm: ${ }^{1} \mathrm{H}: \delta=0.02$ (s, 6H, MeSi), 0.06 (s, 6H, MeSi), 0.95 (s, 18H, 'BuSi), 2.59 (s, 9H, Me $3 \mathrm{~N}$ ); ${ }^{13} \mathrm{C}: \delta=-2.71,-2.30(\mathrm{MeSi}), 27.62\left({ }^{\mathrm{t}} \mathrm{BuSi}\right), 48.12\left(\mathrm{Me}_{3} \mathrm{~N}\right)$.

HRMS (APCI negative ion; n-hexane): m/z calc. for $\mathrm{C}_{15} \mathrm{H}_{39} \mathrm{AlClNSi}_{2}-\mathrm{H}: 350.2041$. Found: $350.1654[\mathrm{M}-\mathrm{H}]^{-}$.

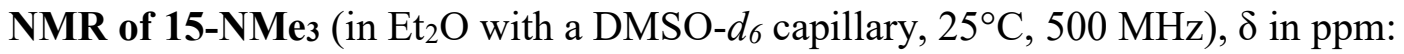

${ }^{1} \mathrm{H}: \delta=0.07$ (s, 6H, MeSi), 0.09 (s, 6H, MeSi), 0.98 (s, 18H, $\left.{ }^{t} \mathbf{B u S i}\right), 2.71\left(\mathrm{~s}, 9 \mathrm{H}, \mathbf{M e}_{3} \mathrm{~N}\right)$; ${ }^{13} \mathrm{C}: \delta=-2.52,-2.26(\mathrm{MeSi}), 28.07\left({ }^{\mathrm{t}} \mathrm{BuSi}\right), 48.76\left(\mathrm{Me}_{3} \mathrm{~N}\right)$.

HRMS (APCI positive ion; n-hexane): m/z calc. for $\mathrm{C}_{15} \mathrm{H}_{39} \mathrm{AlBrNSi}_{2}$ : 395.1614. Found: $395.2319[\mathrm{M}]^{+}$.

NMR of 16-NMe3 (in hexane with a DMSO- $d_{6}$ capillary, $25^{\circ} \mathrm{C}, 500 \mathrm{MHz}$ ), $\delta$ in ppm: ${ }^{1} \mathrm{H}: \delta=0.11(\mathrm{~s}, 18 \mathrm{H}, \mathbf{M e S i}), 0.95\left(\mathrm{~s}, 27 \mathrm{H},{ }^{\mathrm{t}} \mathrm{BuSi}\right), 2.64\left(\mathrm{~s}, 9 \mathrm{H}, \mathrm{Me}_{3} \mathrm{~N}\right) ;{ }^{13} \mathrm{C}: \delta=-0.51$ (MeSi), 28.76 ('BuSi), $52.01\left(\mathrm{Me}_{3} \mathrm{~N}\right)$.

HRMS (APCI positive ion; n-hexane): $\mathrm{m} / \mathrm{z}$ calc. for $\mathrm{C}_{21} \mathrm{H}_{54} \mathrm{AlNSi}_{3}-\mathrm{H}$ : 430.3296. Found: $430.3758[\mathrm{M}-\mathrm{H}]^{+}$.

NMR of 17-NMe 3 (in benzene with a DMSO- $d_{6}$ capillary, $25^{\circ} \mathrm{C}, 500 \mathrm{MHz}$ ), $\delta$ in ppm:

${ }^{1} \mathrm{H}: \delta=0.88(\mathrm{q}, 18 \mathrm{H}, 7.80 \mathrm{~Hz}, \mathrm{CH}), 1.21(\mathrm{t}, 27 \mathrm{H}, 7.80 \mathrm{~Hz}, \mathrm{CH} 3), 1.99\left(\mathrm{~s}, 9 \mathrm{H}, \mathbf{M e}_{3} \mathrm{~N}\right) ;{ }^{13} \mathrm{C}$ : $\delta=6.63\left(\mathrm{CH}_{2}\right), 9.01\left(\mathrm{CH}_{3}\right), 50.60\left(\mathrm{Me}_{3} \mathrm{~N}\right)$.

HRMS (APCI negative ion; n-hexane): m/z calc. for $\mathrm{C}_{21} \mathrm{H}_{54} \mathrm{AlNSi}_{3}-\mathrm{H}$ : 430.3296. Found: $430.1883[\mathrm{M}-\mathrm{H}]^{-}$. 


\section{NMR Spectra}

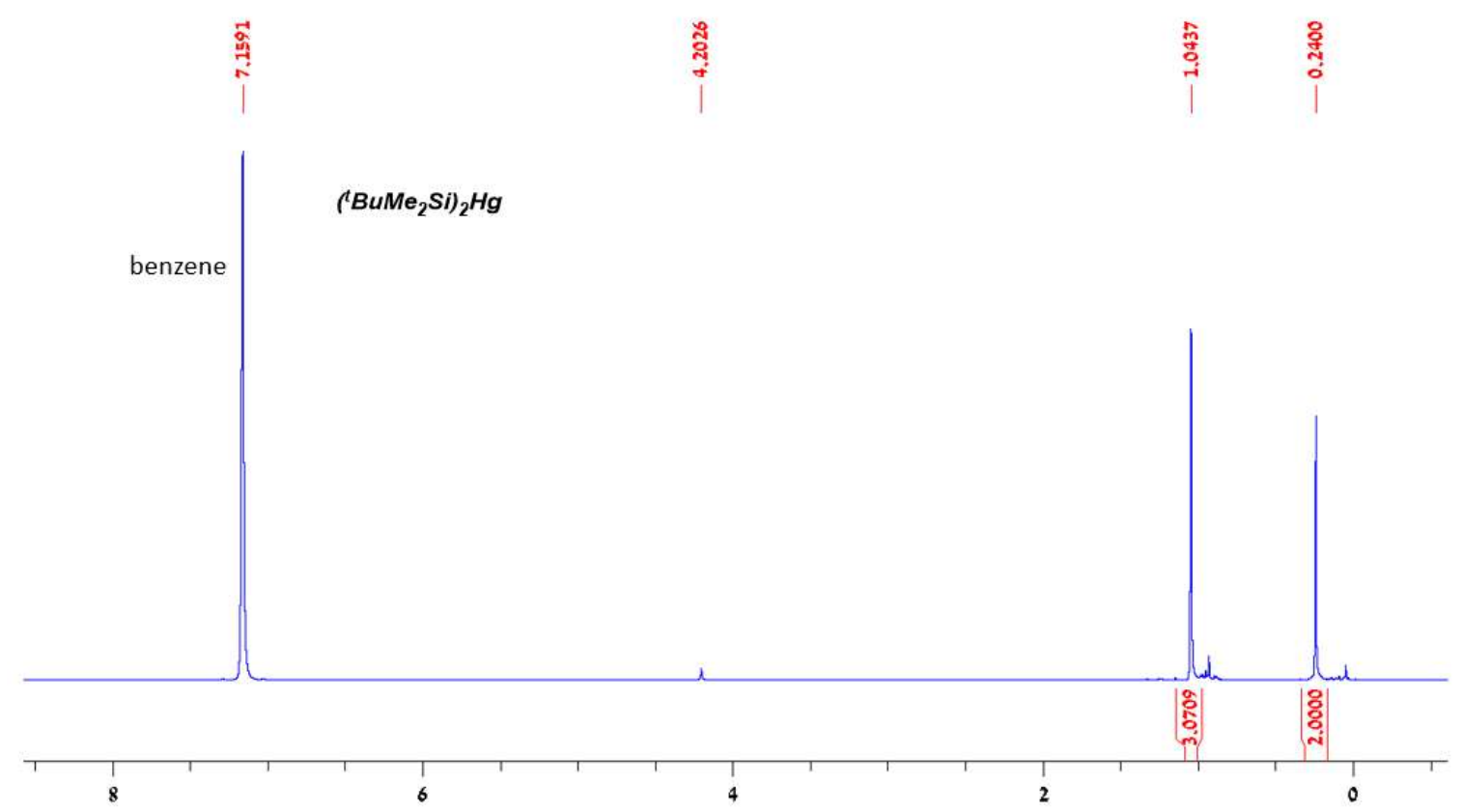

Figure S1. ${ }^{1} \mathrm{H}$ NMR of ( $\left.{ }^{\mathbf{t}} \mathbf{B u M e} \mathbf{M} \mathbf{S i}\right) 2 \mathbf{H g}$ in benzene.

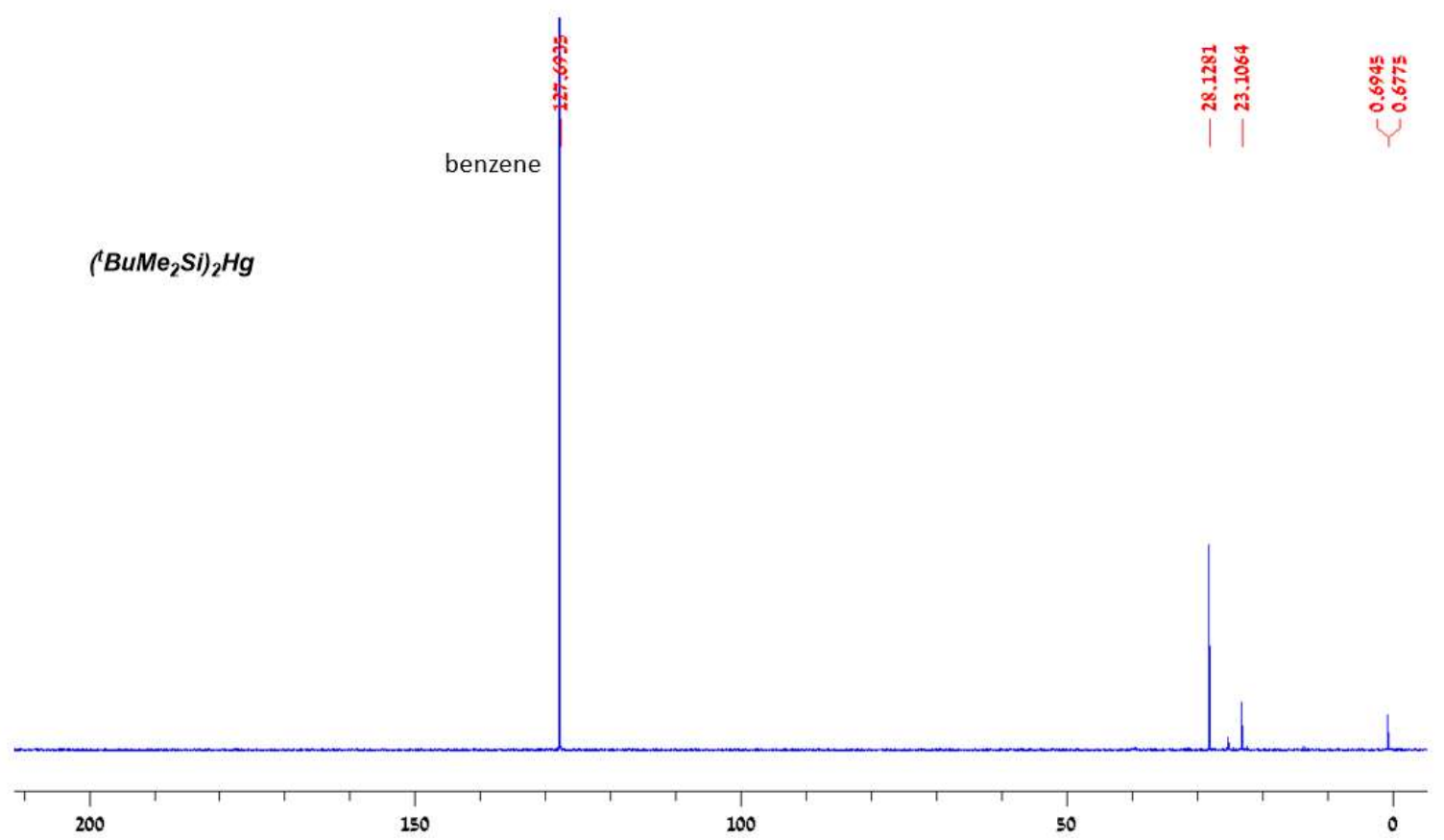

Figure S2. ${ }^{13} \mathrm{C}$ NMR of $\left({ }^{\mathrm{t}} \mathrm{BuMe} \mathbf{M i}\right)_{2} \mathbf{H g}$ in benzene. 


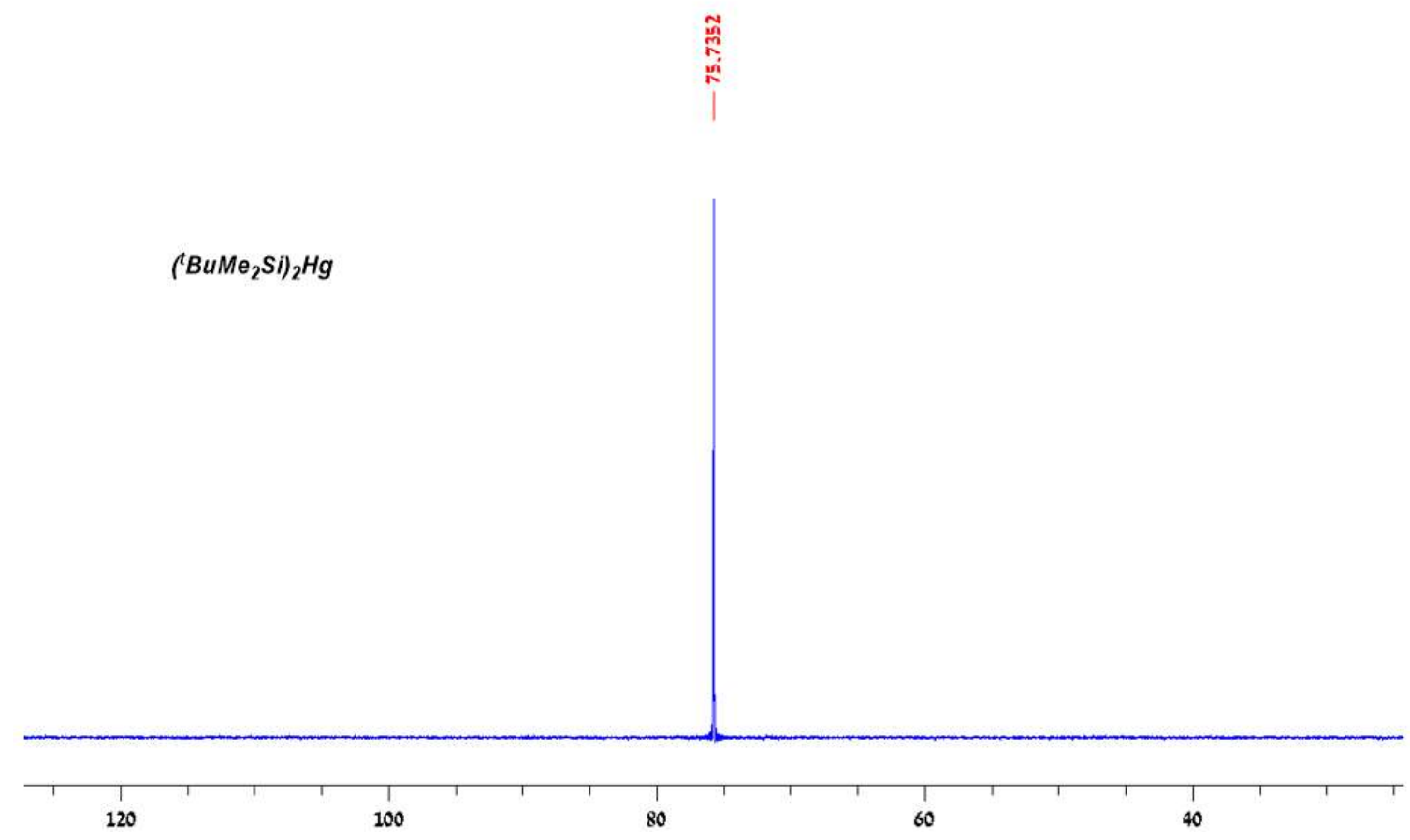

Figure S3. ${ }^{29} \mathrm{Si} \mathrm{NMR}$ of $\left({ }^{\mathrm{t}} \mathrm{BuMe} \mathbf{M} \mathbf{S i}\right)_{2} \mathbf{H g}$ in benzene.

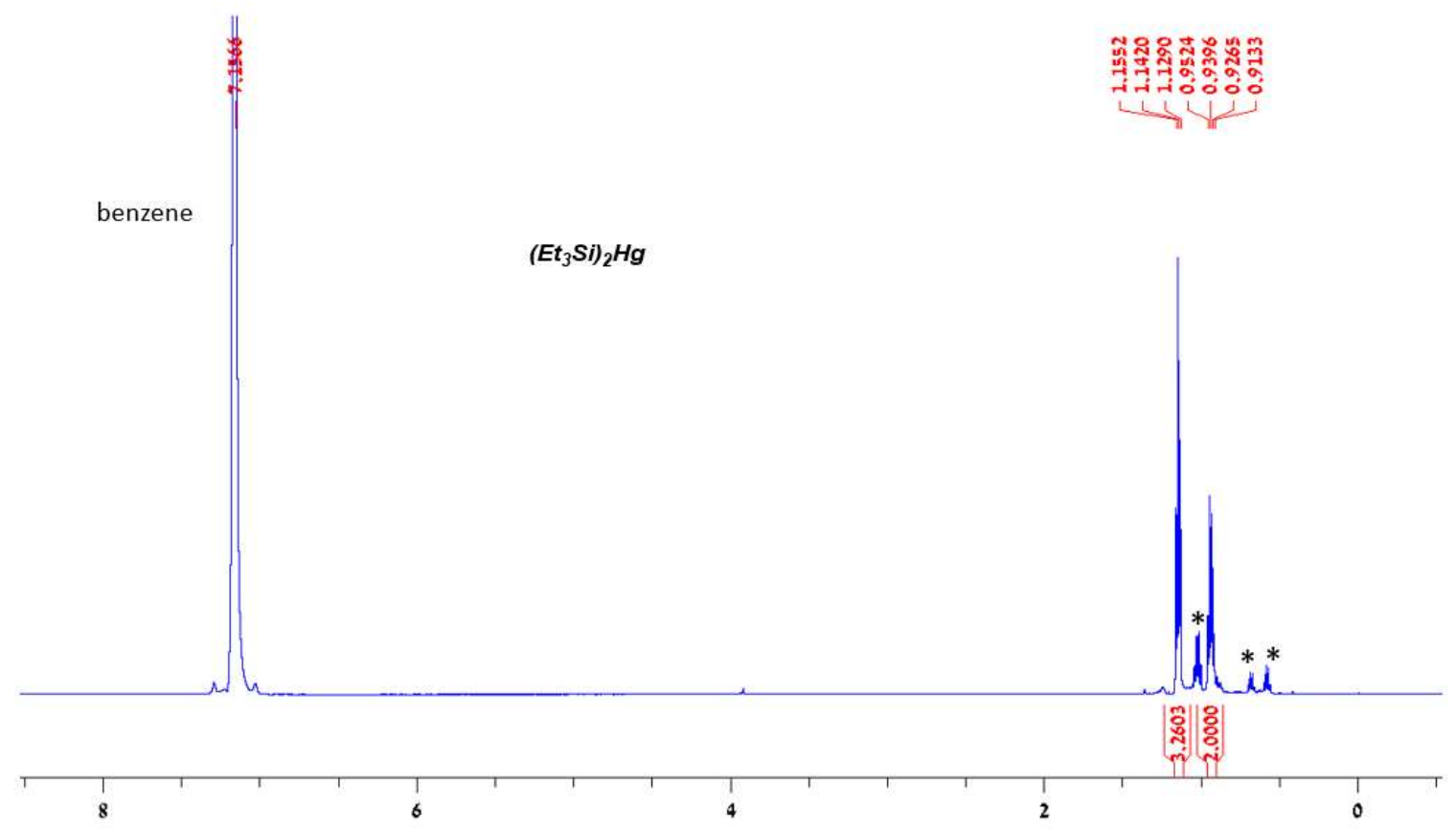

Figure S4. ${ }^{1} \mathrm{H}$ NMR of $\left(\mathbf{E t}_{3} \mathbf{S i}\right)_{2} \mathbf{H g}$ in benzene contaminated with unknown by-products containing ethyl groups (marked with *). 


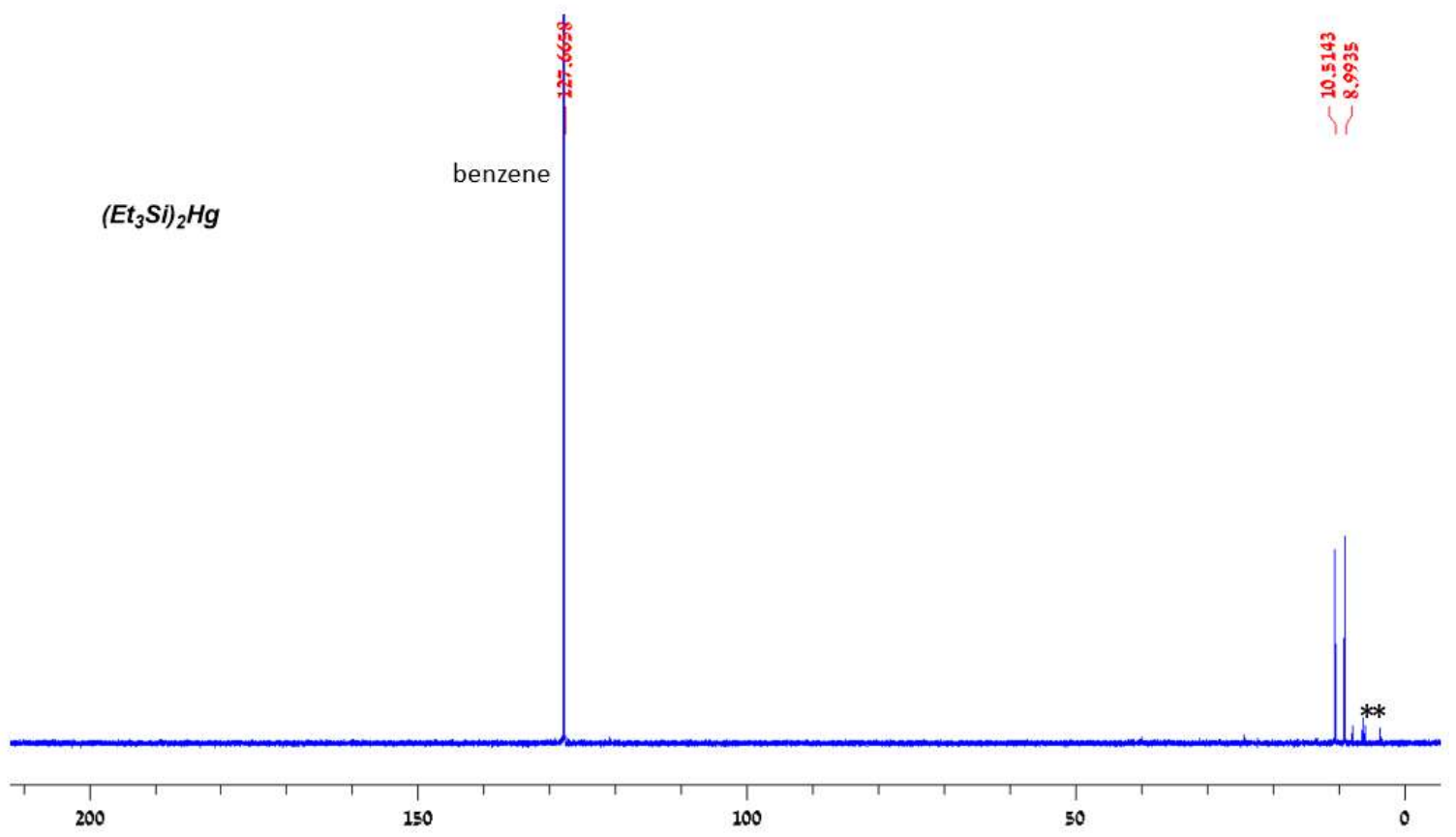

Figure S5. ${ }^{13} \mathrm{C}$ NMR of $\left(\mathbf{E t}_{3} \mathbf{S i}\right)_{2} \mathbf{H g}$ in benzene contaminated with unknown by-products containing ethyl groups (marked with*).

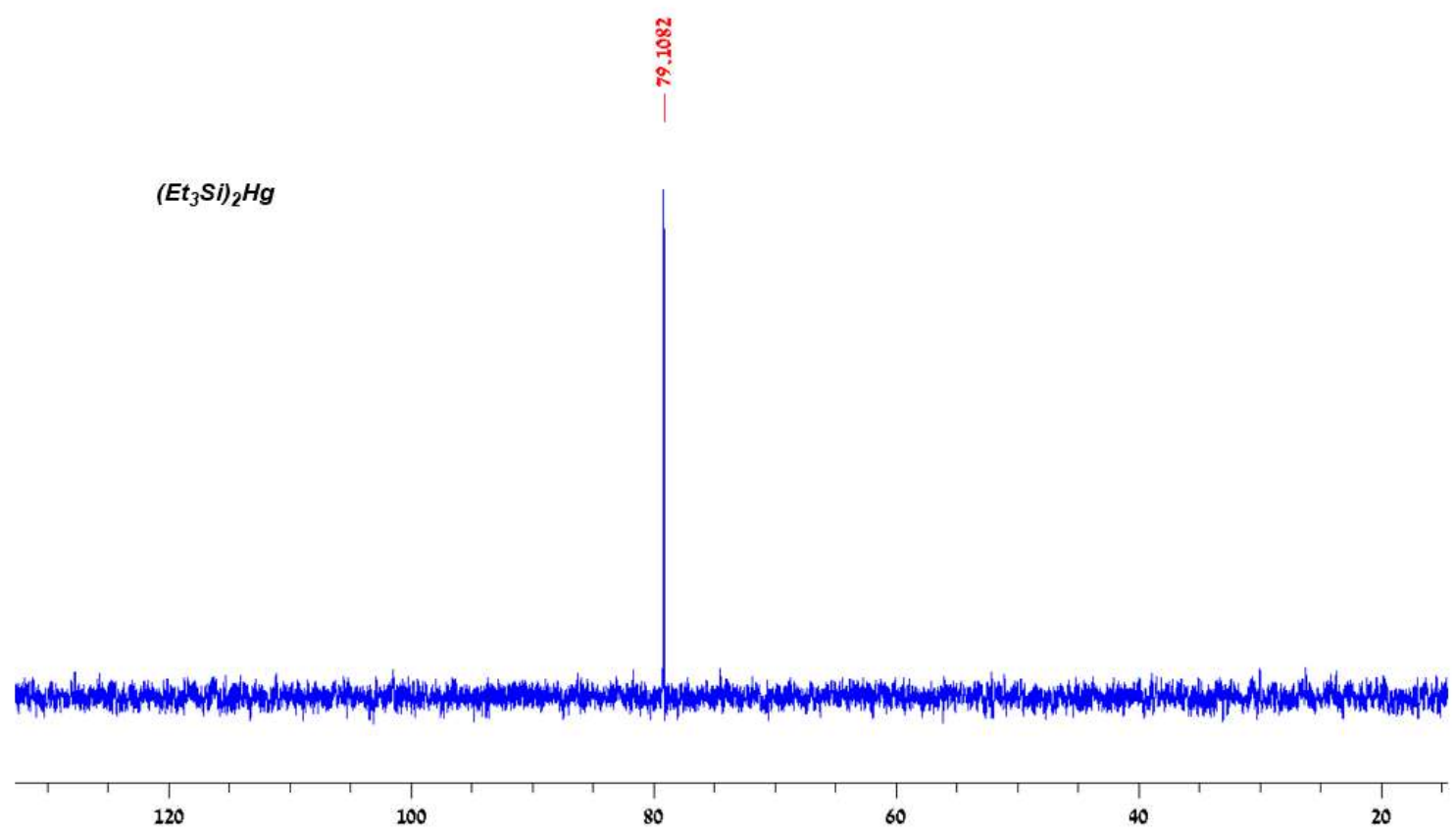

Figure S6. ${ }^{29} \mathrm{Si} \mathrm{NMR}$ of $\left(\mathbf{E t} \mathbf{t}_{3} \mathbf{S i}\right)_{2} \mathbf{H g}$ in benzene. 


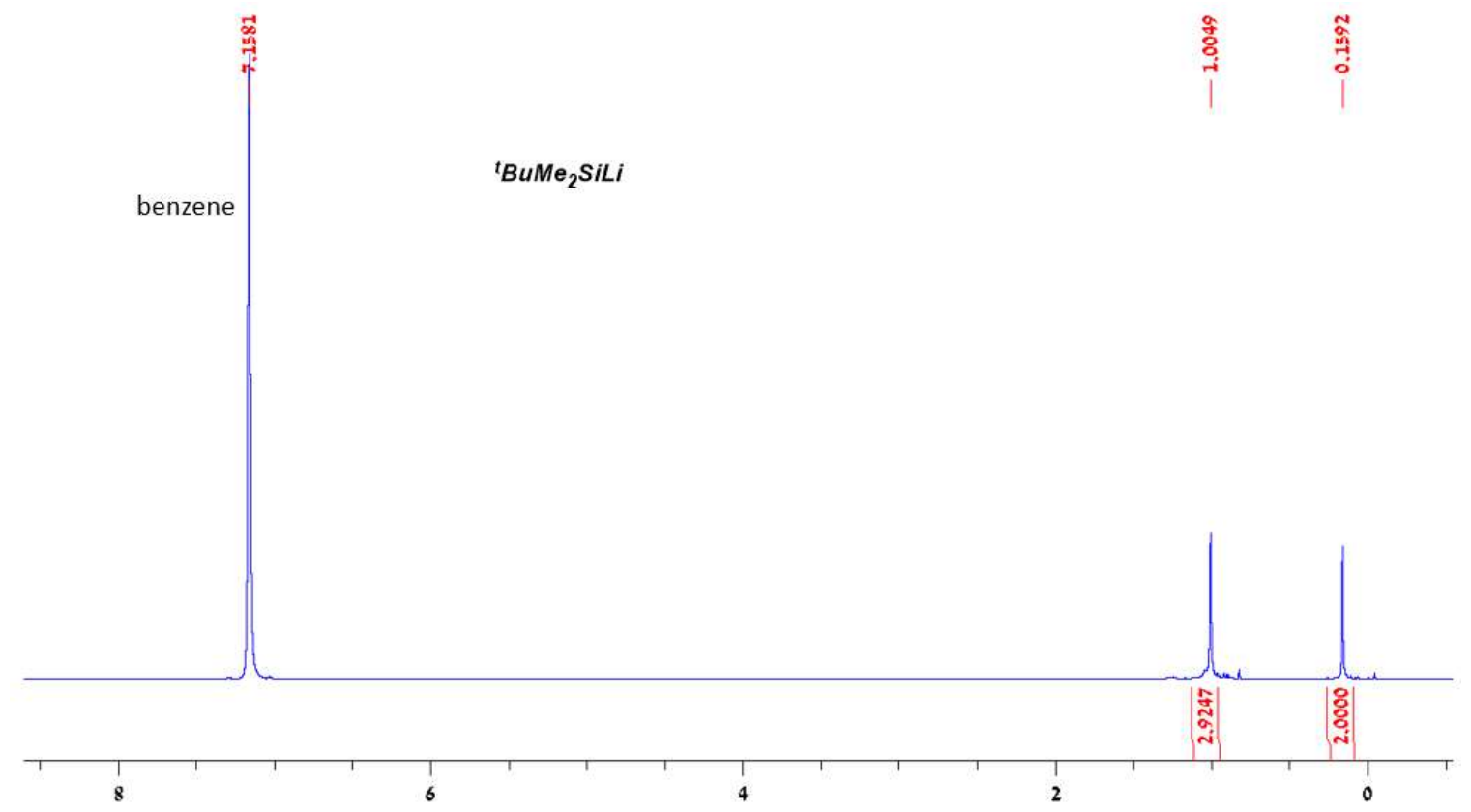

Figure S7. ${ }^{1} \mathrm{H}$ NMR of ${ }^{\mathbf{t}} \mathbf{B u M e} \mathbf{S} S i L i$ in benzene.

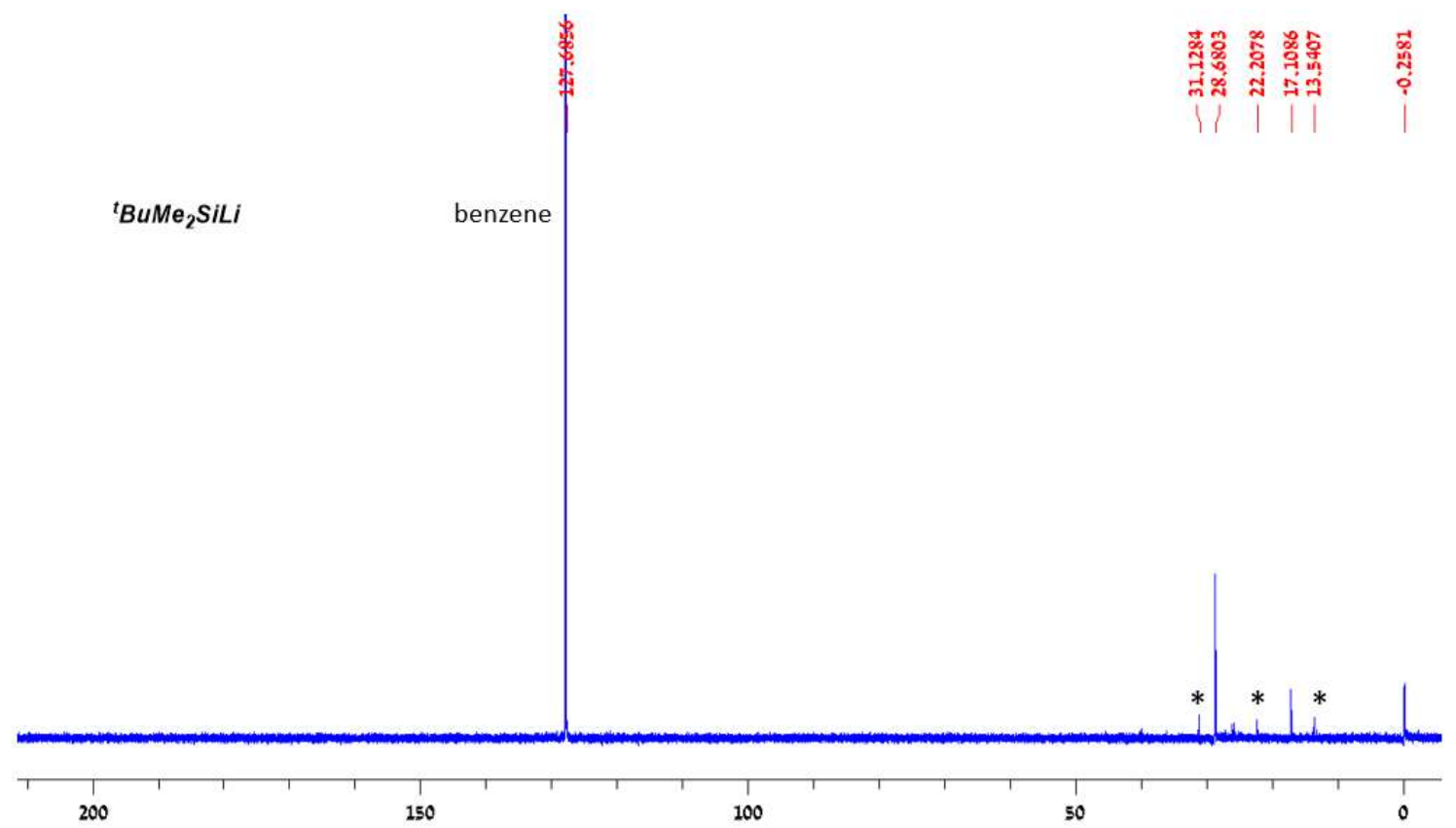

Figure S8. ${ }^{13} \mathrm{C}$ NMR of ${ }^{\mathrm{t}} \mathrm{BuMe}$ SiLi in benzene (*: hexane). 


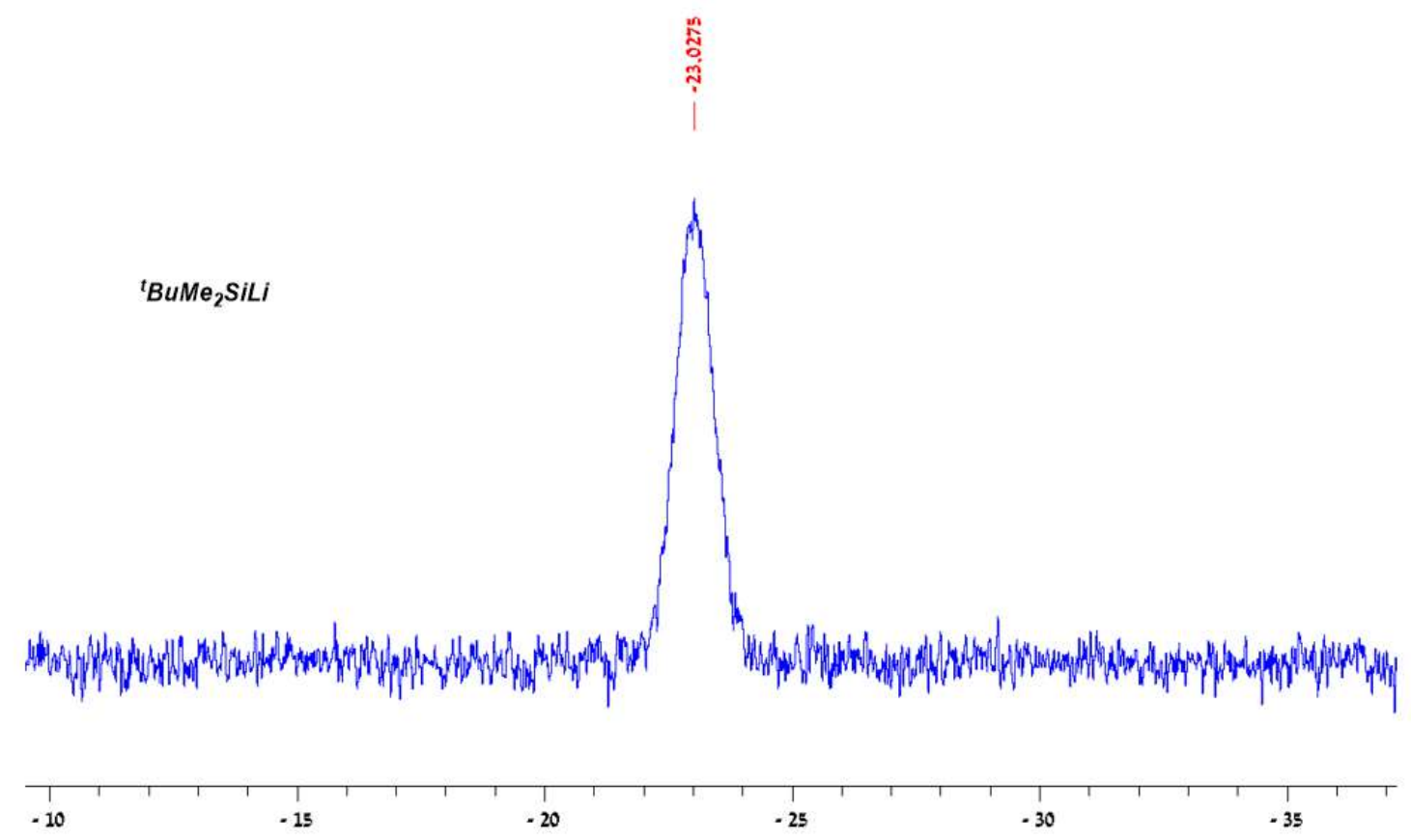

Figure S9. ${ }^{29} \mathrm{Si}$ NMR of ${ }^{\mathbf{t}} \mathbf{B u M e} \mathbf{S i L i}$ in benzene.

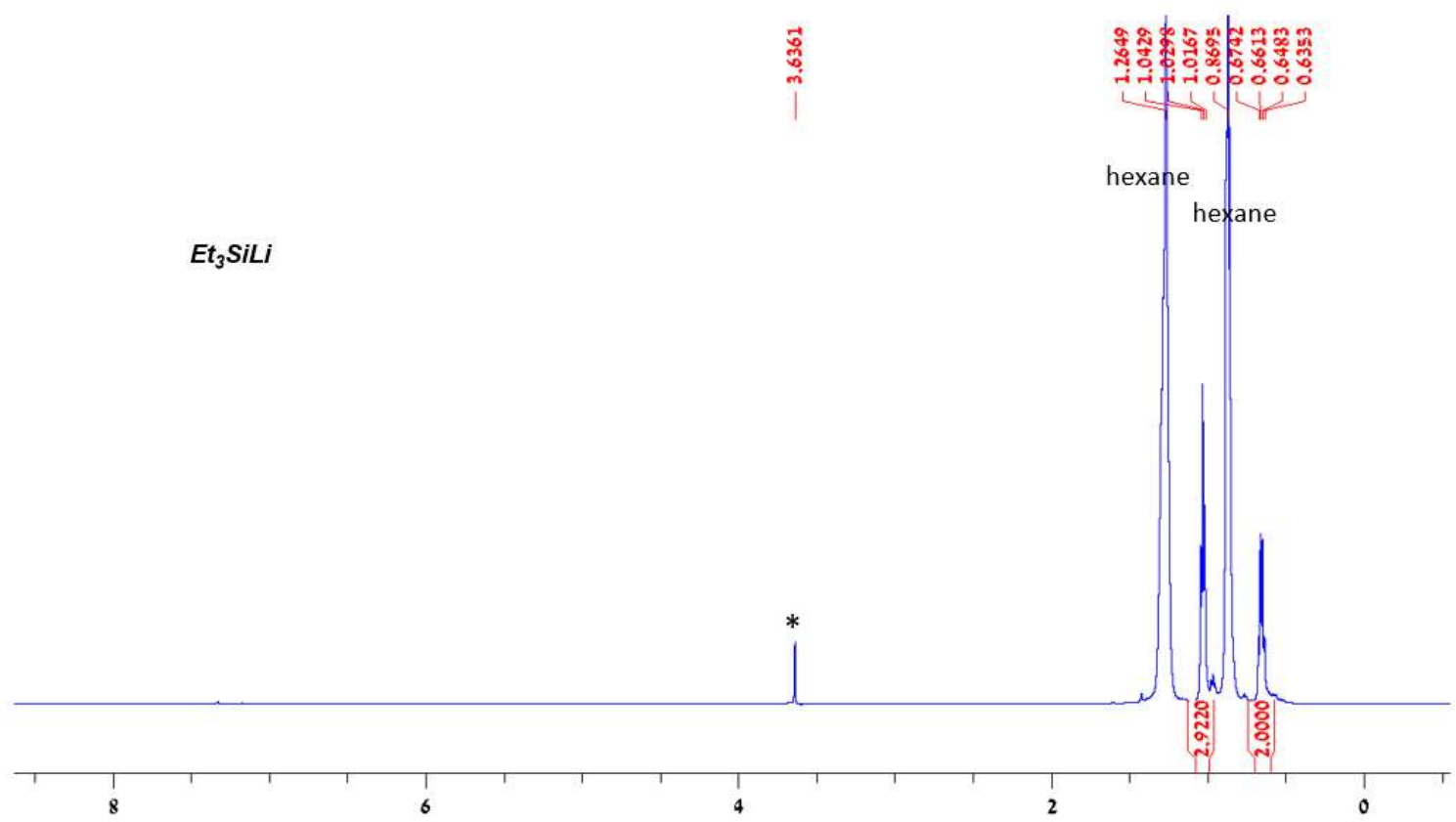

Figure S10. ${ }^{1} \mathrm{H}$ NMR of Et $\mathbf{t}_{3} \mathrm{SiLi}$ in benzene (*: traces of $\mathrm{H}_{2} \mathrm{O}$ in DMSO- $d_{6}$ capillary). 


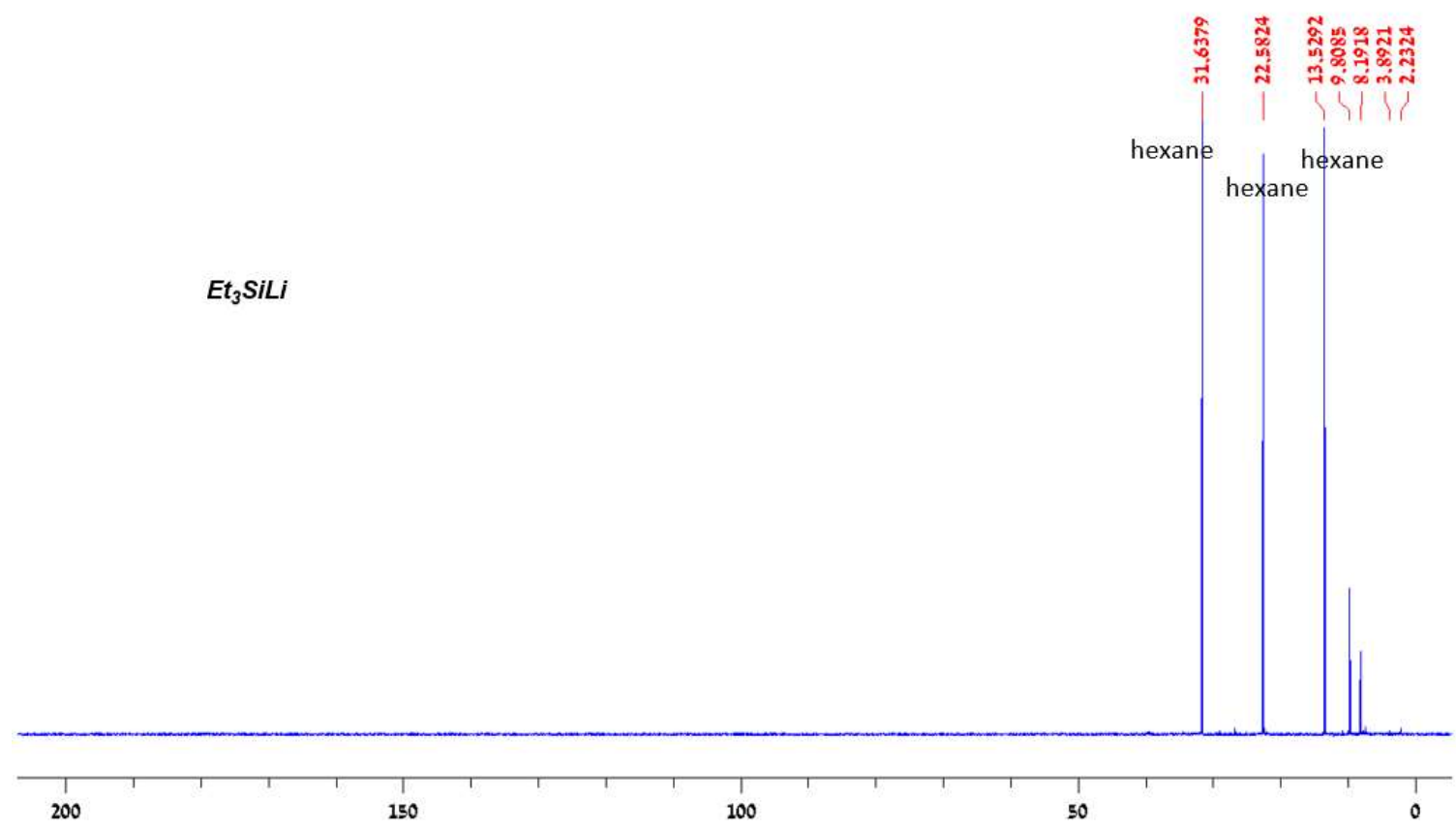

Figure S1 $1 .{ }^{13} \mathrm{C}$ NMR of Et $\mathbf{t}_{3}$ SiLi in benzene.

i

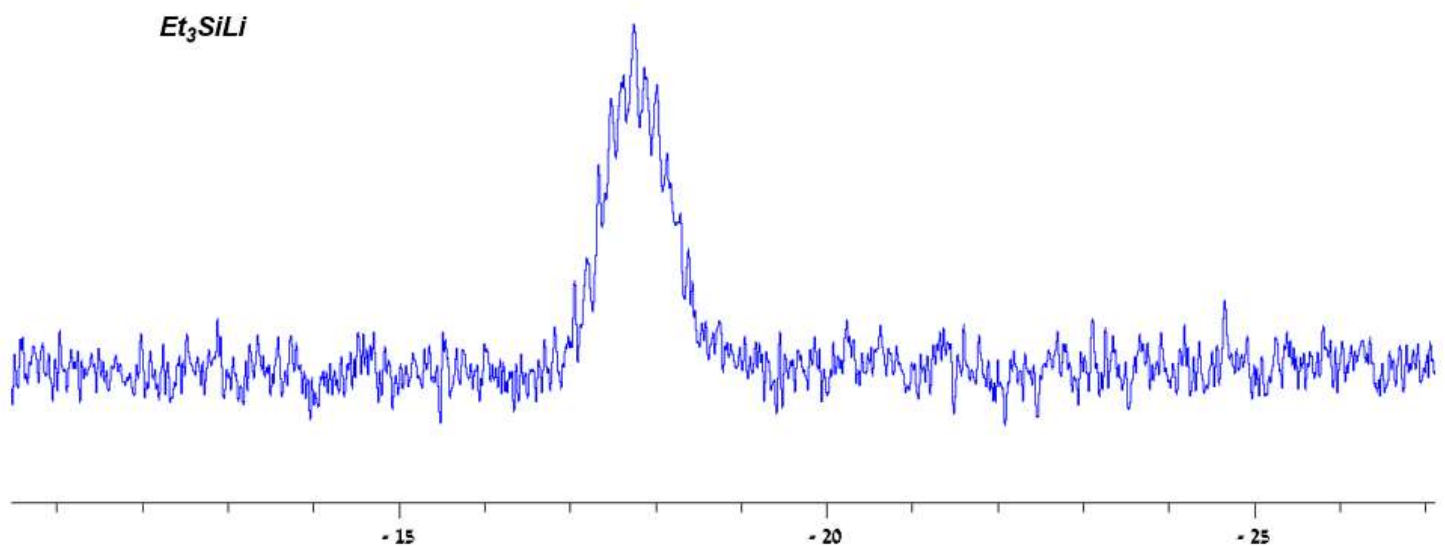

Figure S12. ${ }^{29} \mathrm{Si}$ NMR of Et $\mathbf{3}$ SiLi in benzene. 


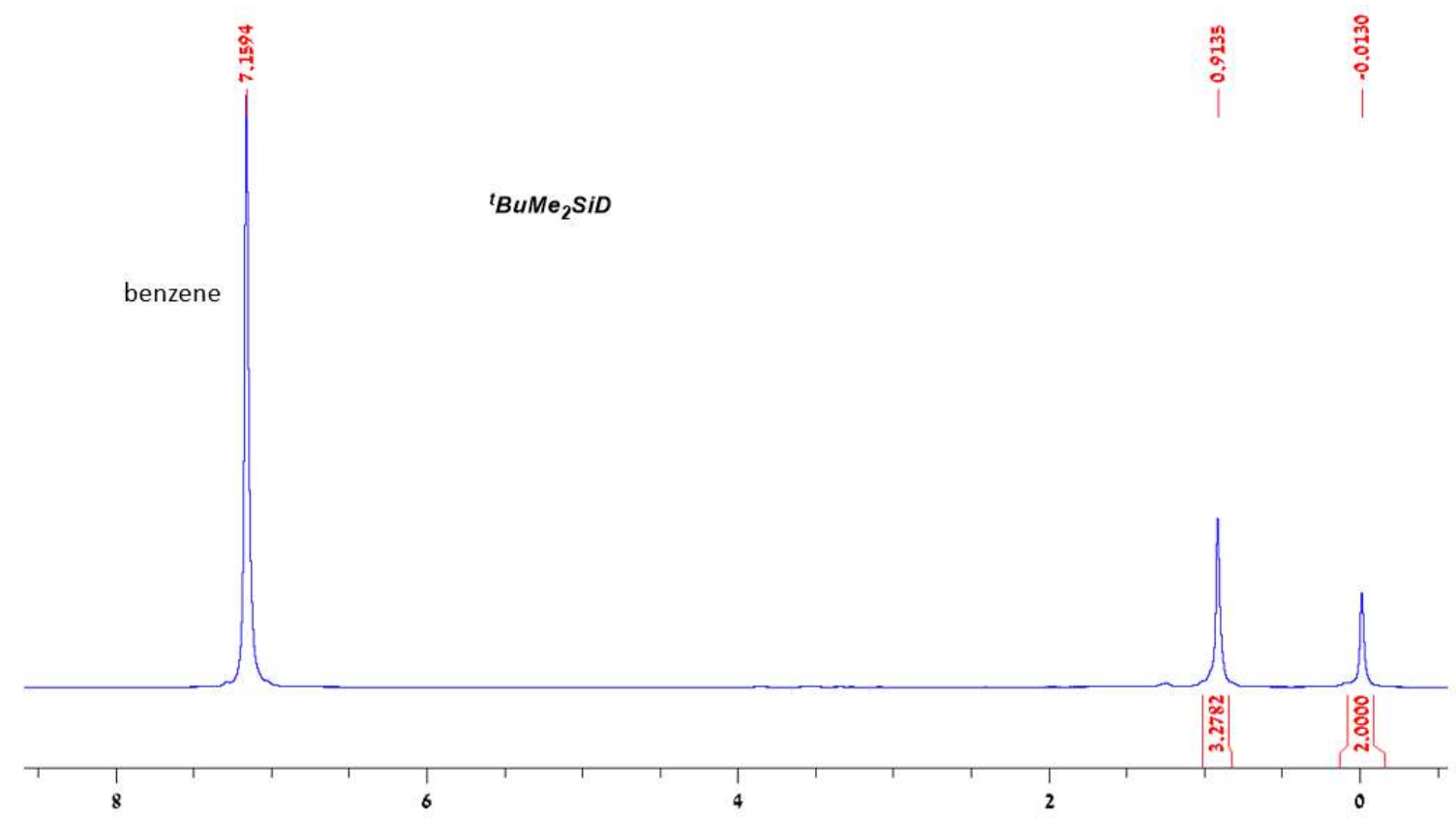

Figure S13. ${ }^{1} \mathrm{H}$ NMR of ${ }^{\mathrm{t}} \mathrm{BuMe}_{2} \mathrm{SiD}$ in benzene.

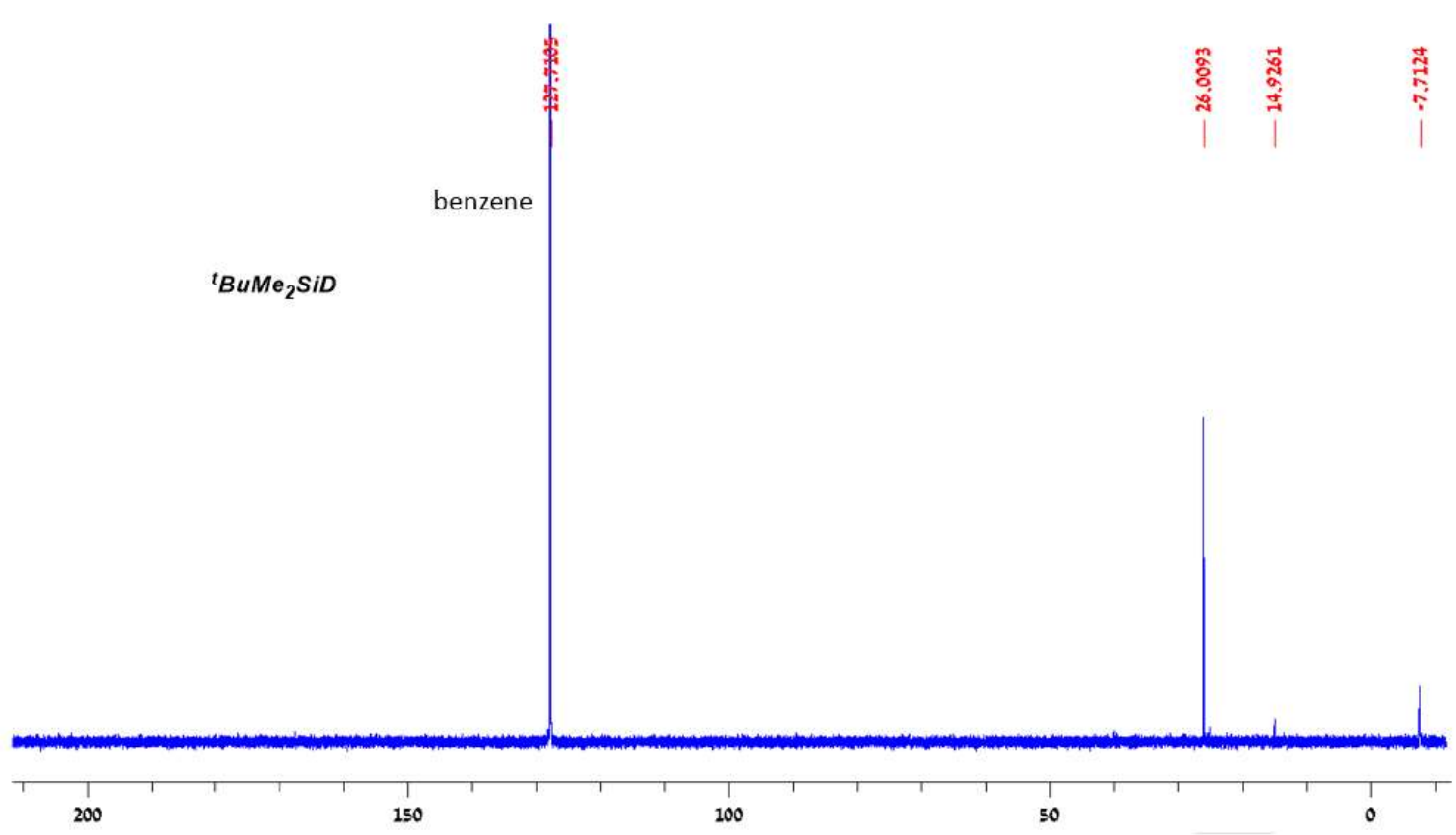

Figure S14. ${ }^{13} \mathrm{C}$ NMR of ${ }^{\mathbf{t}} \mathbf{B u M e 2 S i D}$ in benzene. 


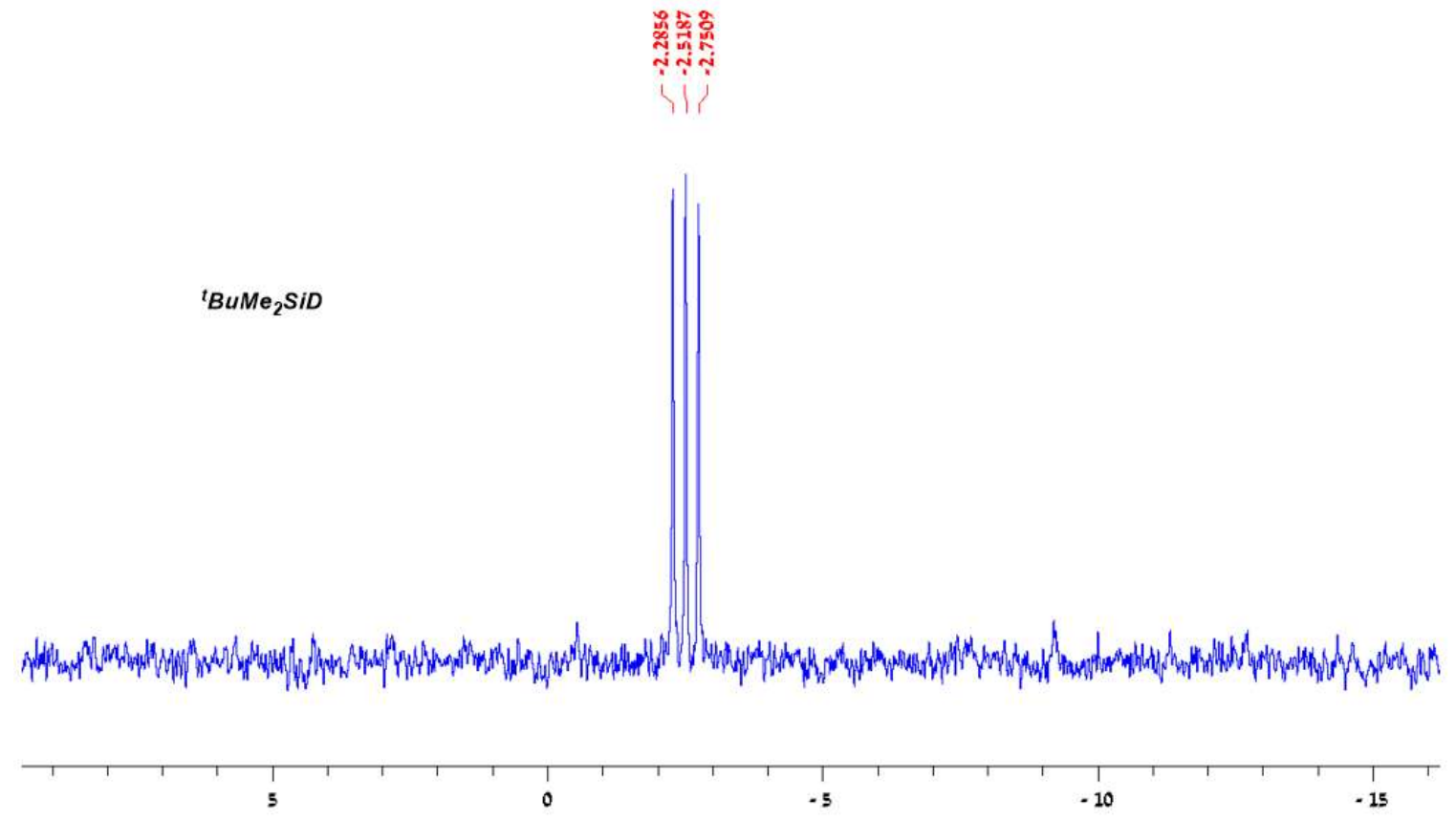

Figure S15. ${ }^{29} \mathrm{Si}$ NMR of ${ }^{\mathbf{t}} \mathbf{B u M e}$ SiD in benzene.

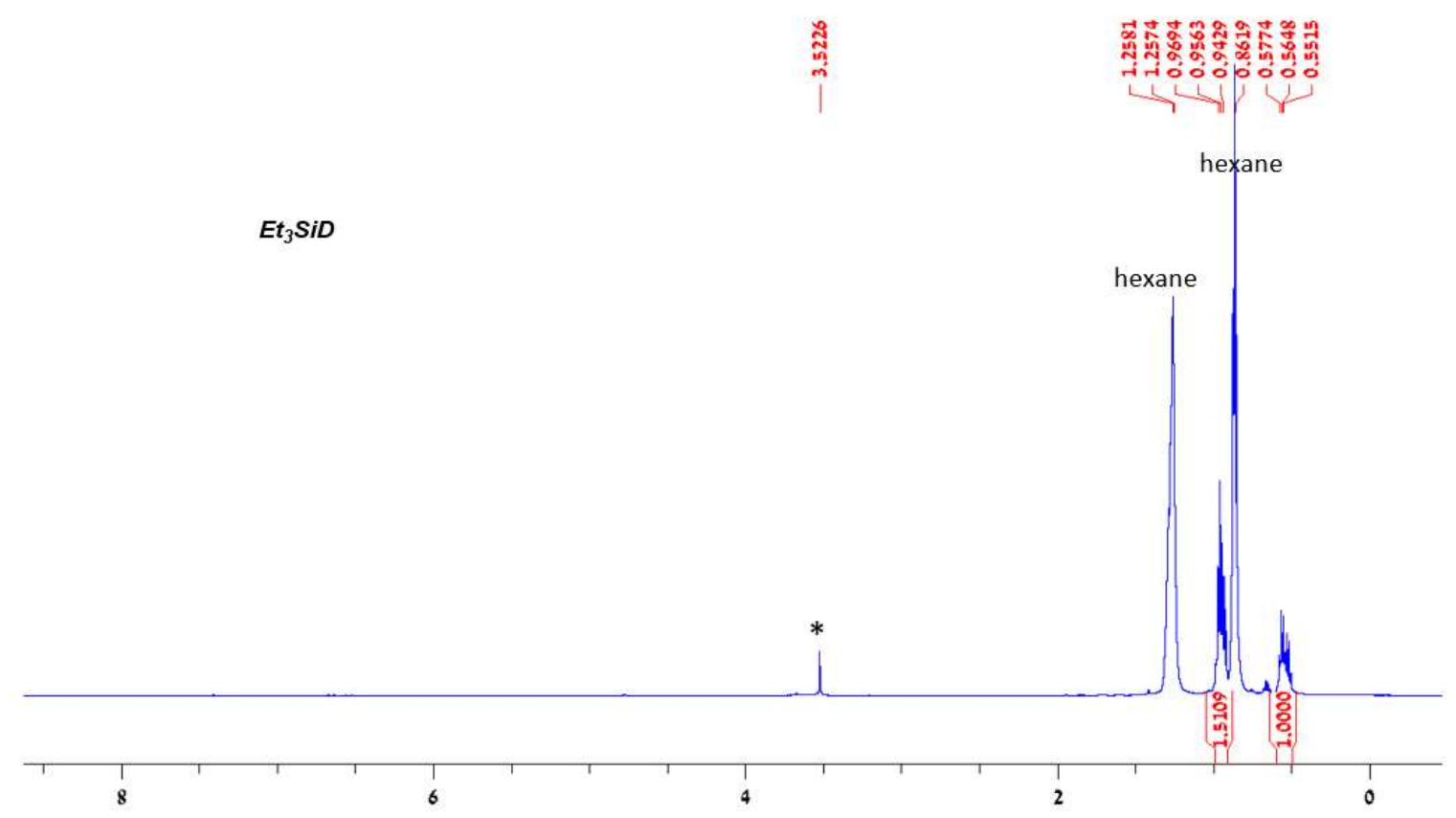

Figure S16. ${ }^{1} \mathrm{H}$ NMR of Et 3 SiD in benzene (*: traces of $\mathrm{H}_{2} \mathrm{O}$ in DMSO- $d_{6}$ capillary). 


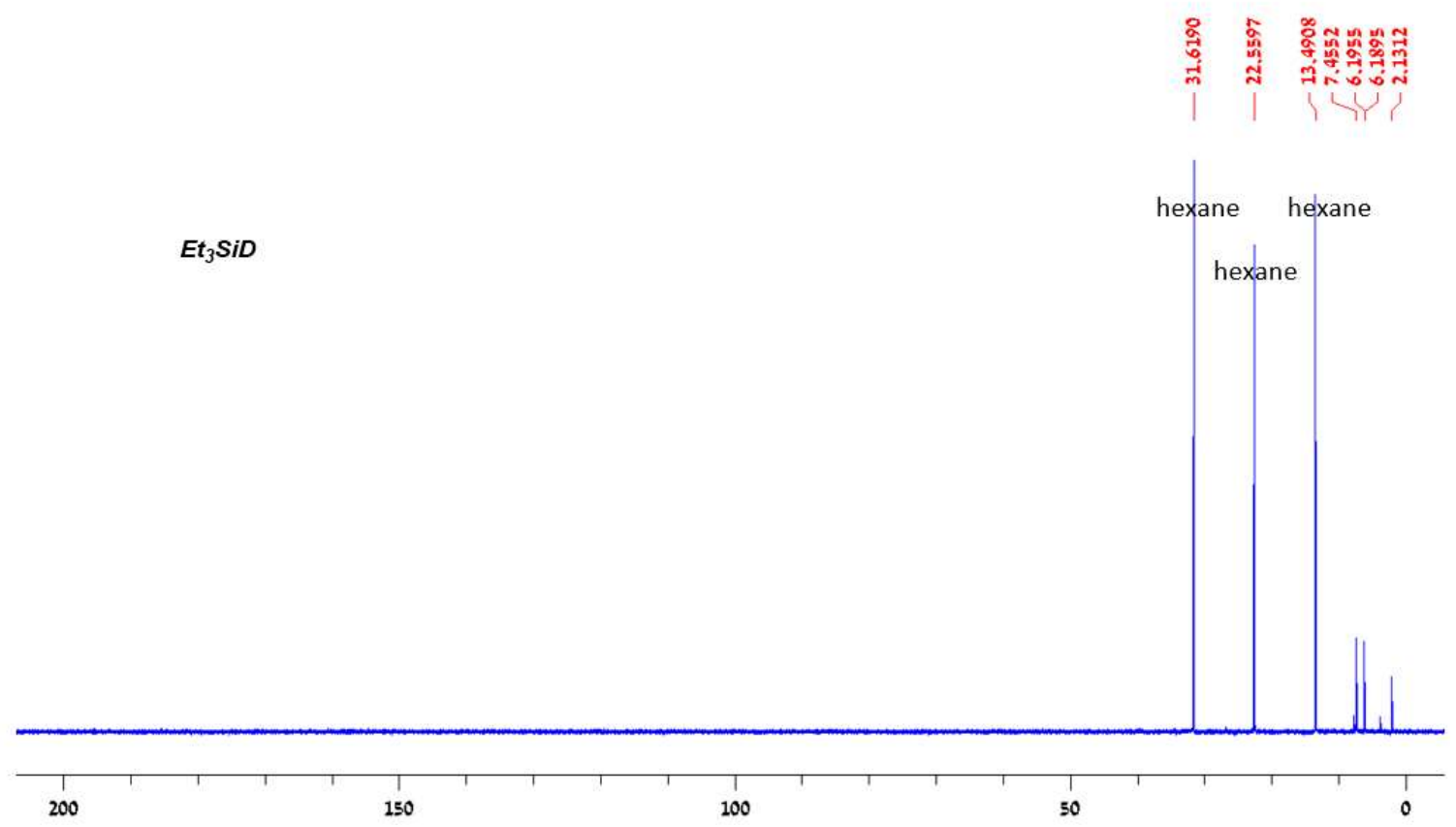

Figure S17. ${ }^{13} \mathrm{C}$ NMR of Et $\mathbf{t}_{3}$ SiD in benzene.

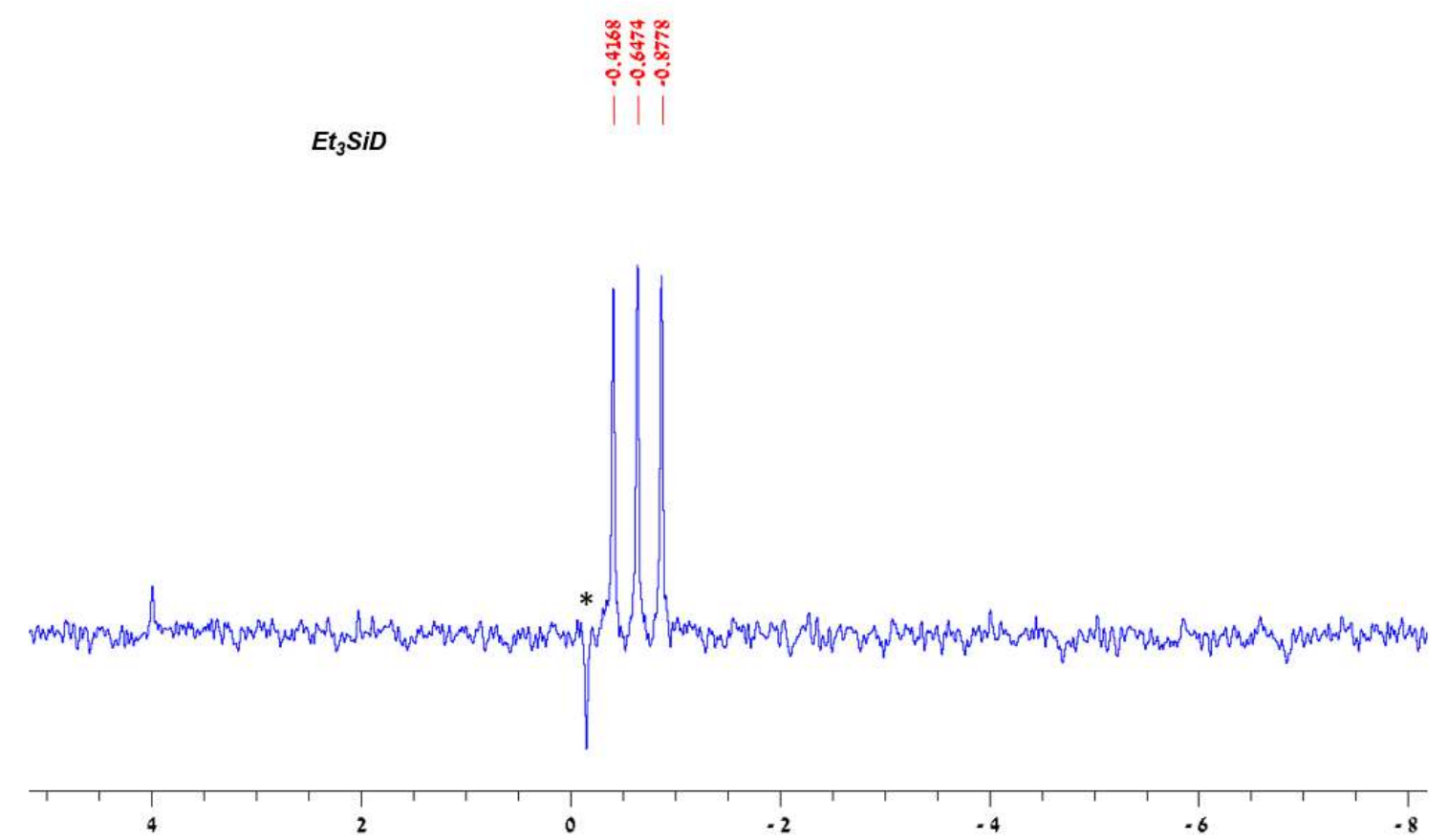

Figure S18. ${ }^{29} \mathrm{Si} \mathrm{NMR}$ of Et $\mathbf{t}_{3} \mathrm{SiD}$ in benzene (*: Et $\left.{ }_{3} \mathrm{SiH}\right)$. 


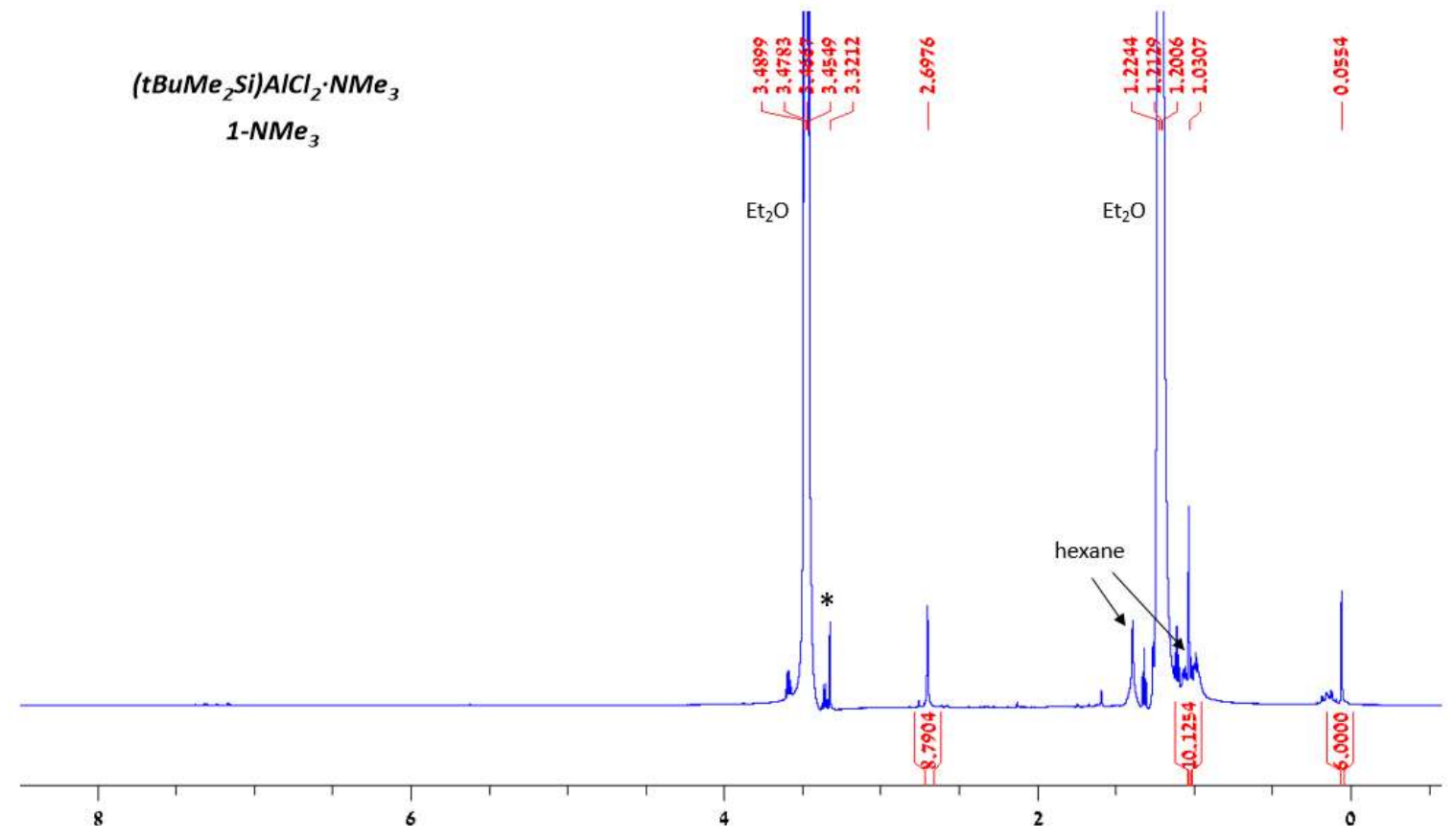

Figure S19. ${ }^{1} \mathrm{H}$ NMR of 1-NMe 3 in $\mathrm{Et}_{2} \mathrm{O}$ (*: traces of $\mathrm{H}_{2} \mathrm{O}$ in DMSO- $d_{6}$ capillary).

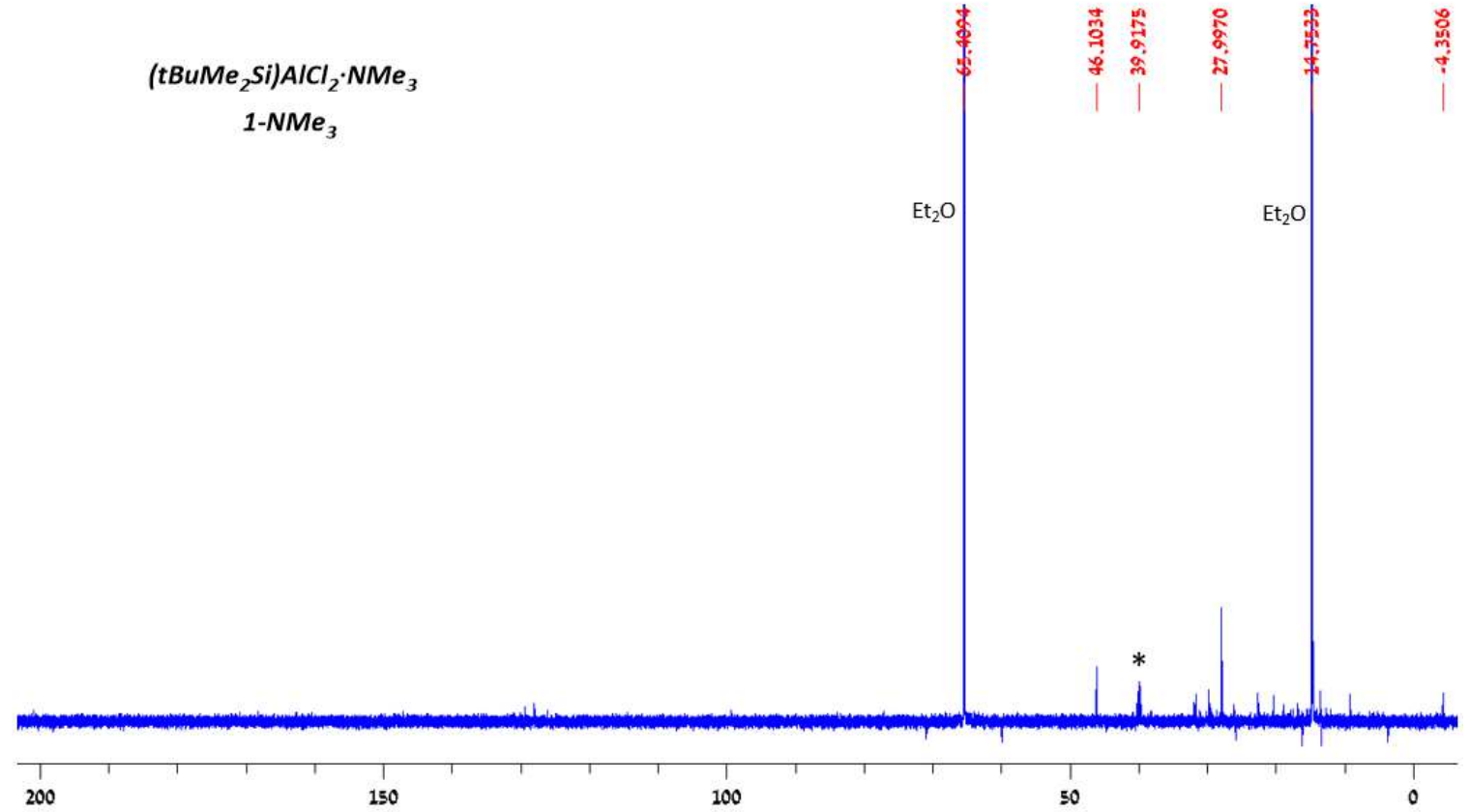

Figure S20. ${ }^{13} \mathrm{C}$ NMR of 1-NMe $\mathrm{N}_{3}$ in $\mathrm{Et}_{2} \mathrm{O}$ (*: DMSO- $d_{6}$ capillary). 


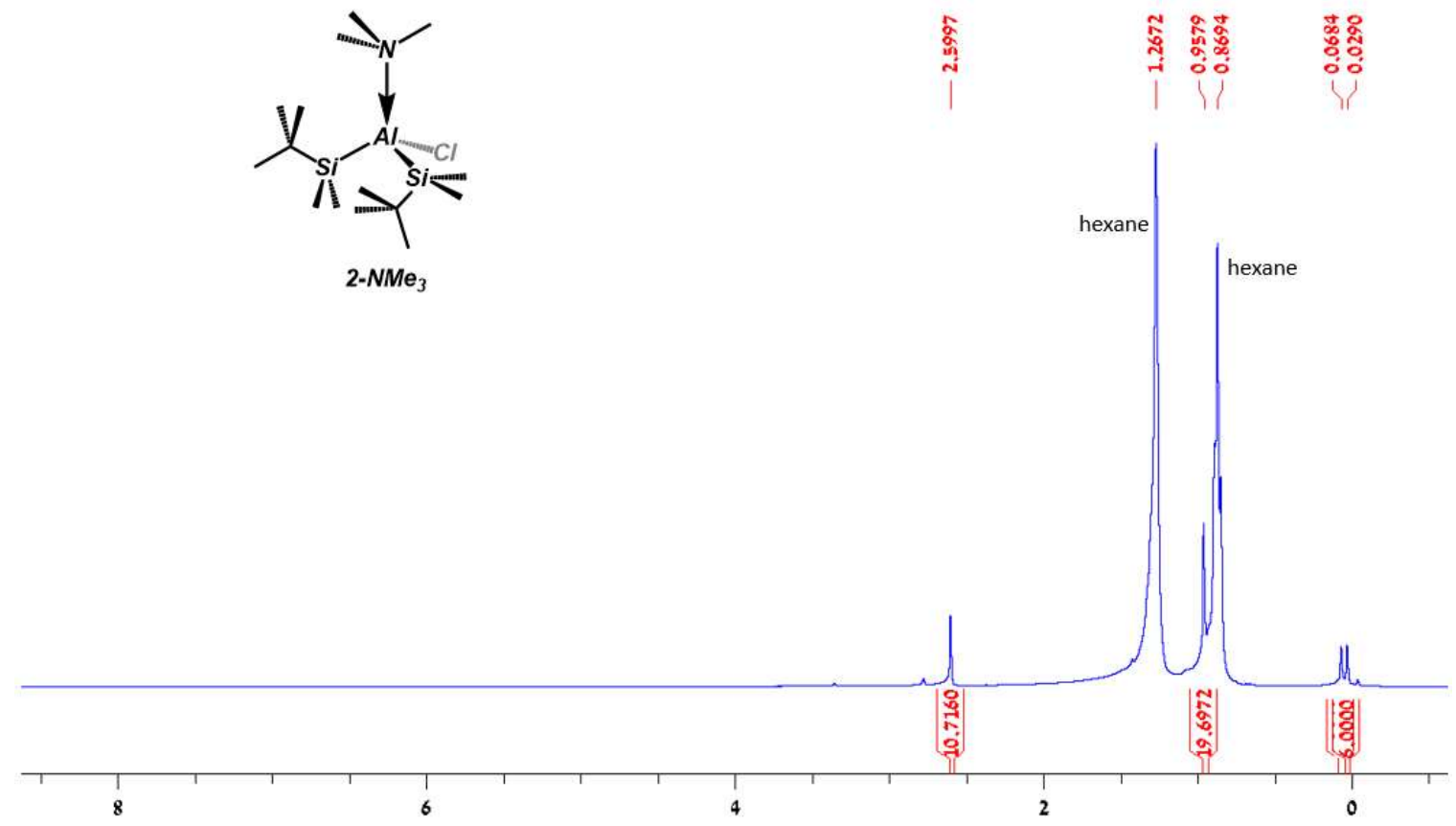

Figure S21. ${ }^{1} \mathrm{H}$ NMR of 2-NMe 3 in hexane.

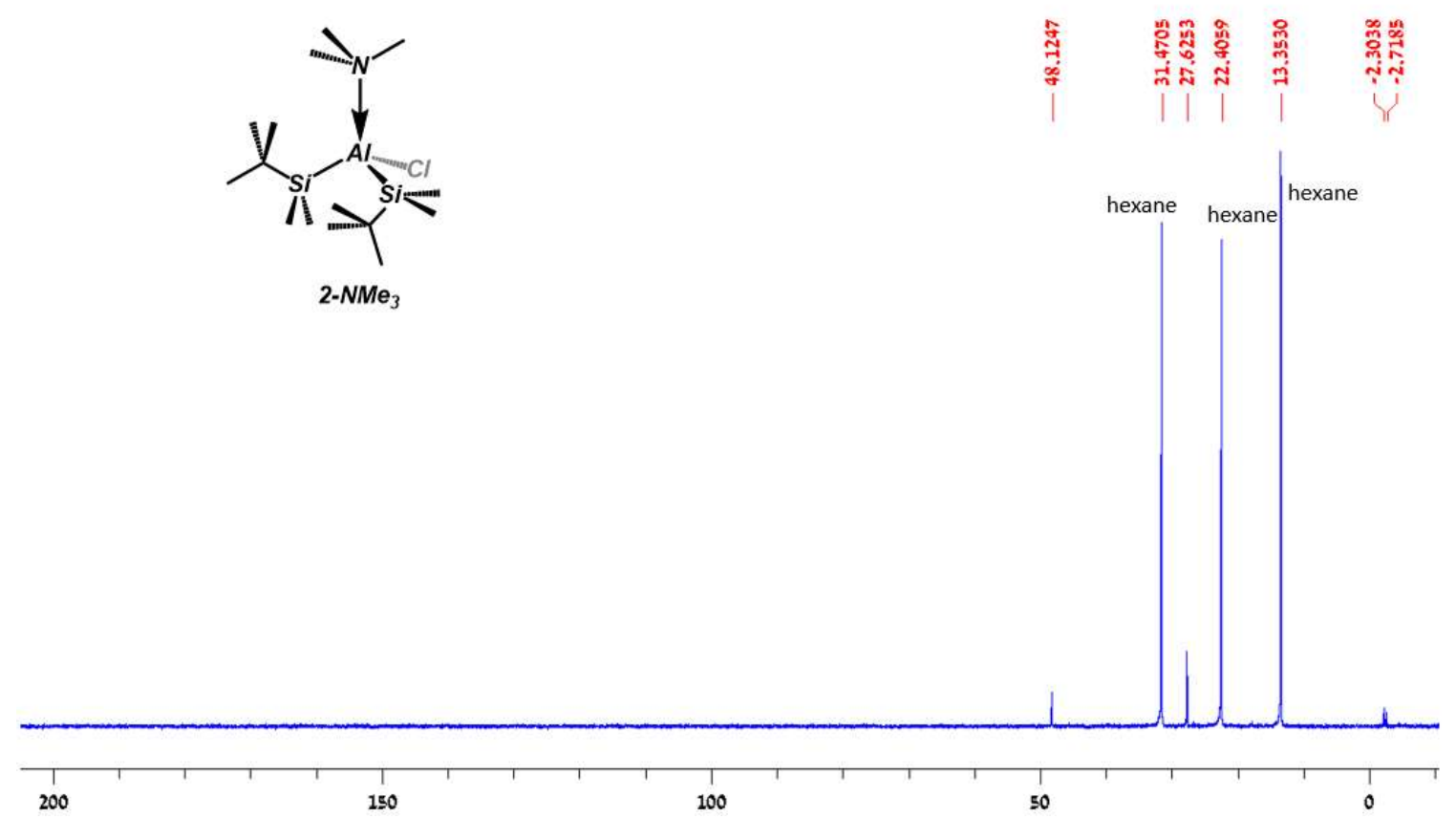

Figure S22. ${ }^{13} \mathrm{C}$ NMR of 2-NMez in hexane. 


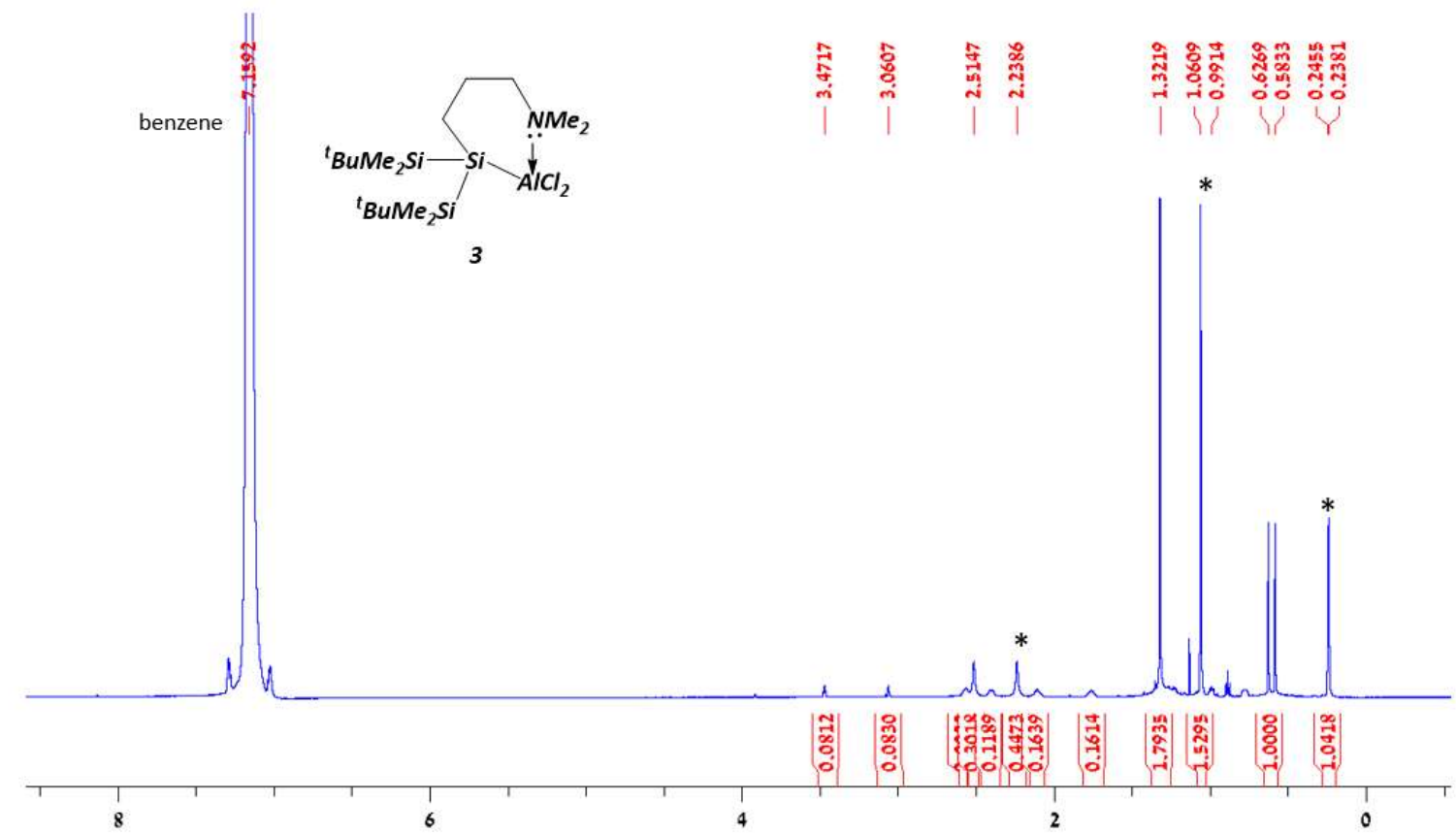

Figure S23. ${ }^{1} \mathrm{H}$ NMR of 3 in benzene with contamination of $\mathrm{Me}_{2} \mathrm{~N}\left(\mathrm{CH}_{2}\right)_{3}\left({ }^{(} \mathrm{BuMe} \mathrm{Si}_{2}\right)_{2} \mathrm{SiH}$ (marked with *).

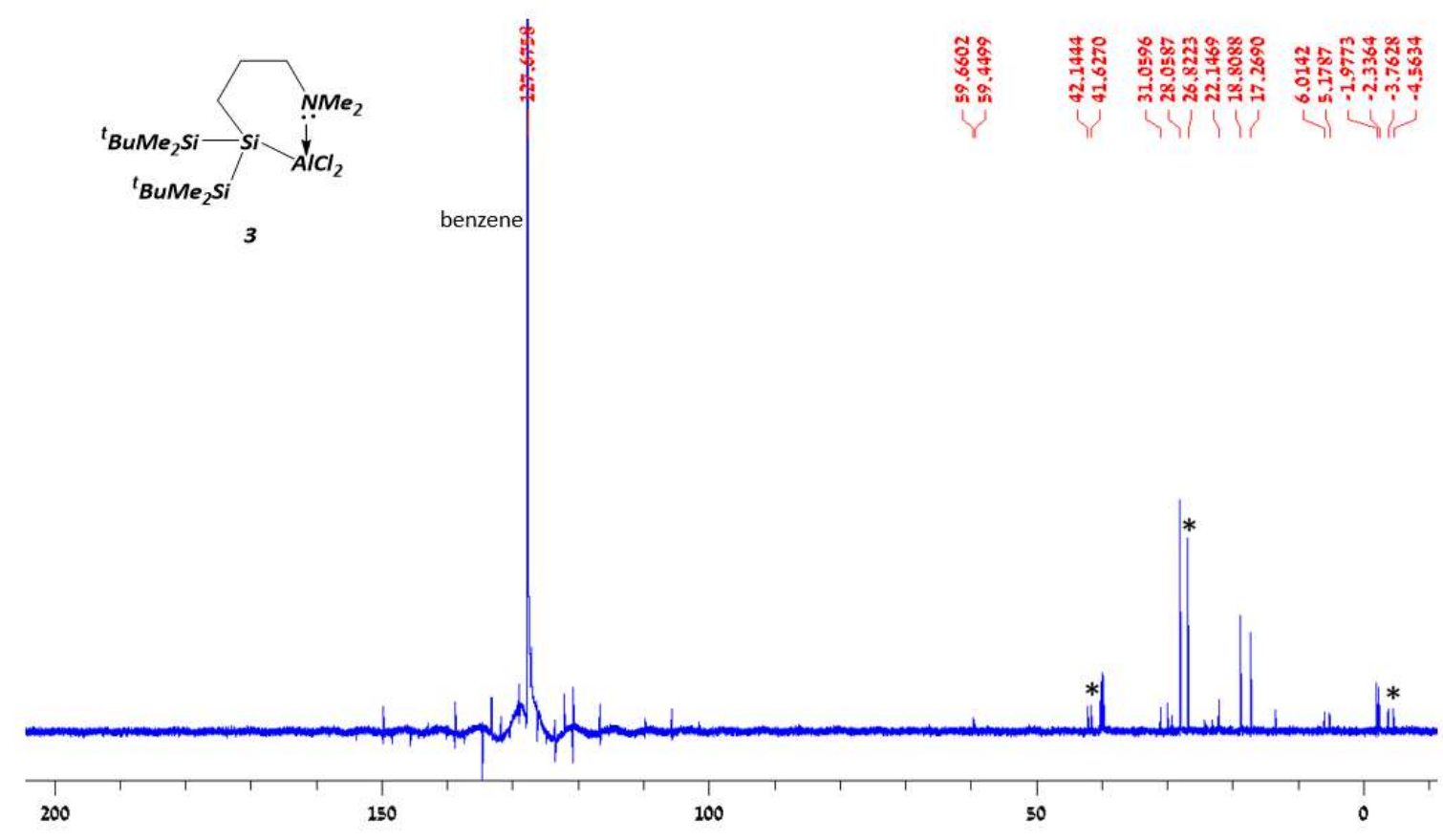

Figure S24. ${ }^{13} \mathrm{C}$ NMR of 3 in benzene with contamination of $\mathrm{Me}_{2} \mathrm{~N}\left(\mathrm{CH}_{2}\right)_{3}\left({ }^{\mathrm{t}} \mathrm{BuMe} \mathrm{Si}_{2}\right)_{2} \mathrm{SiH}$ (marked with *). 


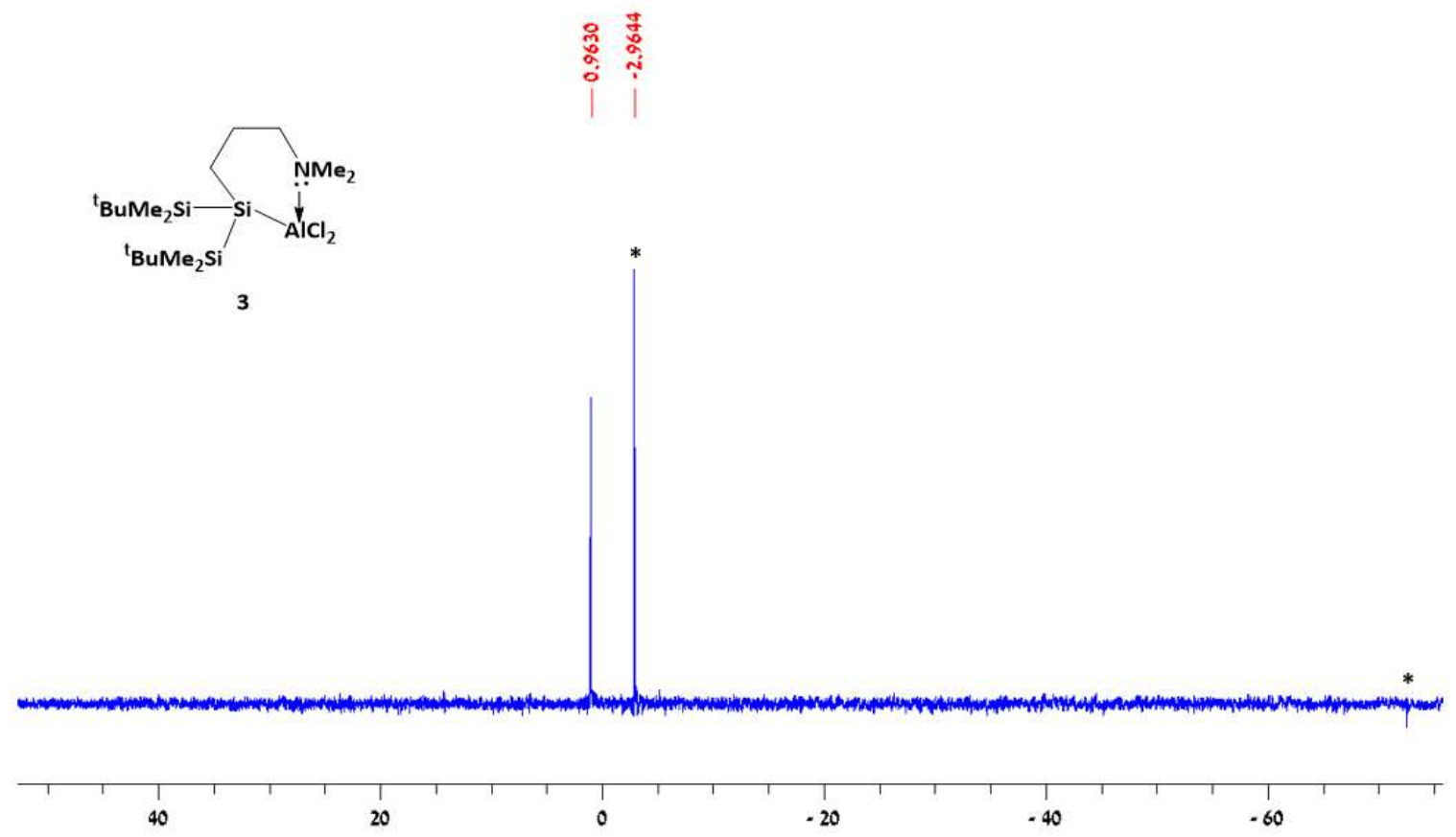

Figure S25. ${ }^{29} \mathrm{Si}$ NMR of 3 in benzene with contamination of $\mathrm{Me}_{2} \mathrm{~N}\left(\mathrm{CH}_{2}\right)_{3}\left({ }^{\mathrm{t}} \mathrm{BuMe}_{2} \mathrm{Si}\right)_{2} \mathrm{SiH}$ (marked with *).

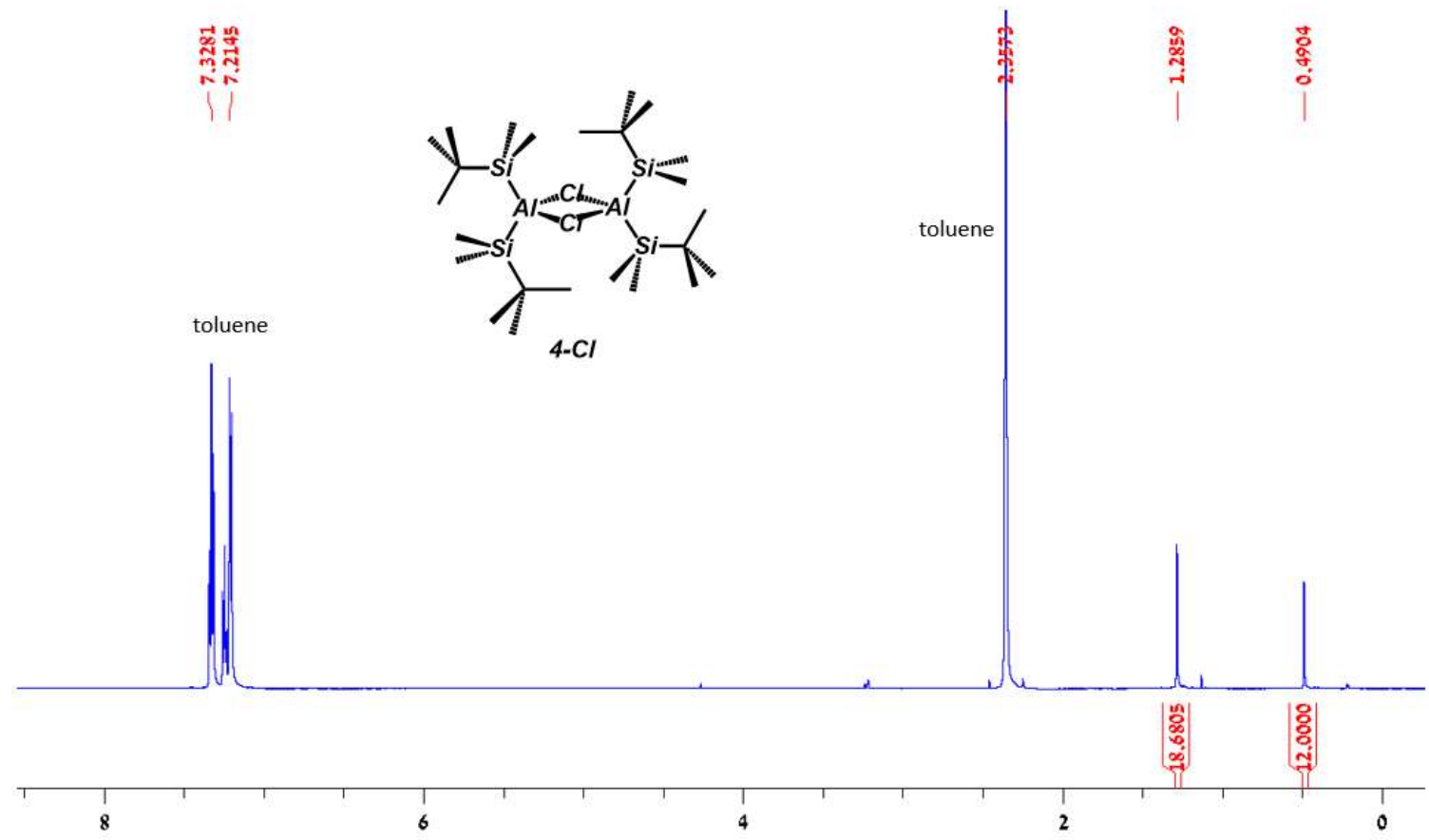

Figure S26. ${ }^{1} \mathrm{H}$ NMR of 4-Cl in toluene. 


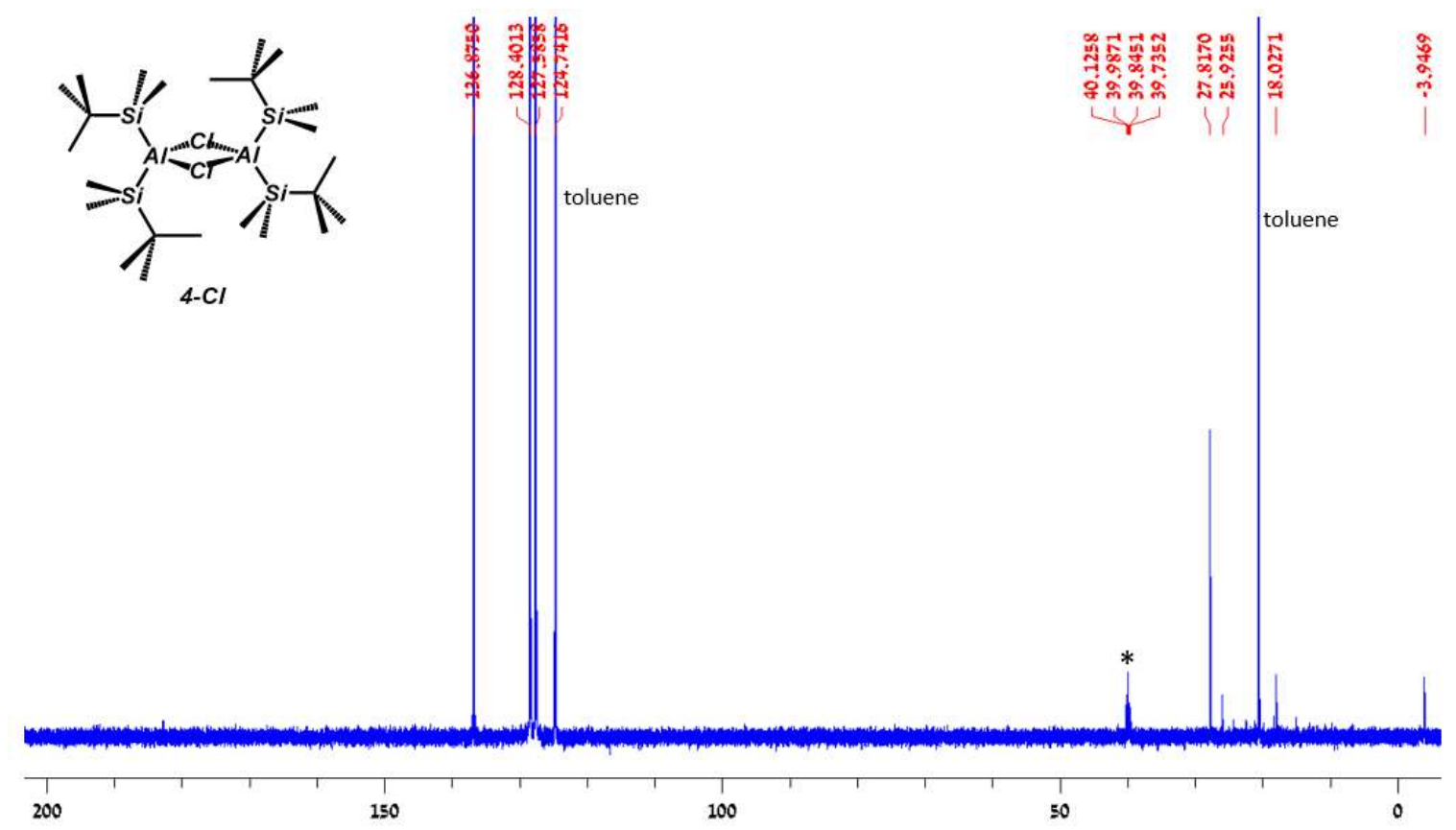

Figure S27. ${ }^{13} \mathrm{C}$ NMR of $4-\mathbf{C l}$ in toluene (*: DMSO- $d_{6}$ capillary).

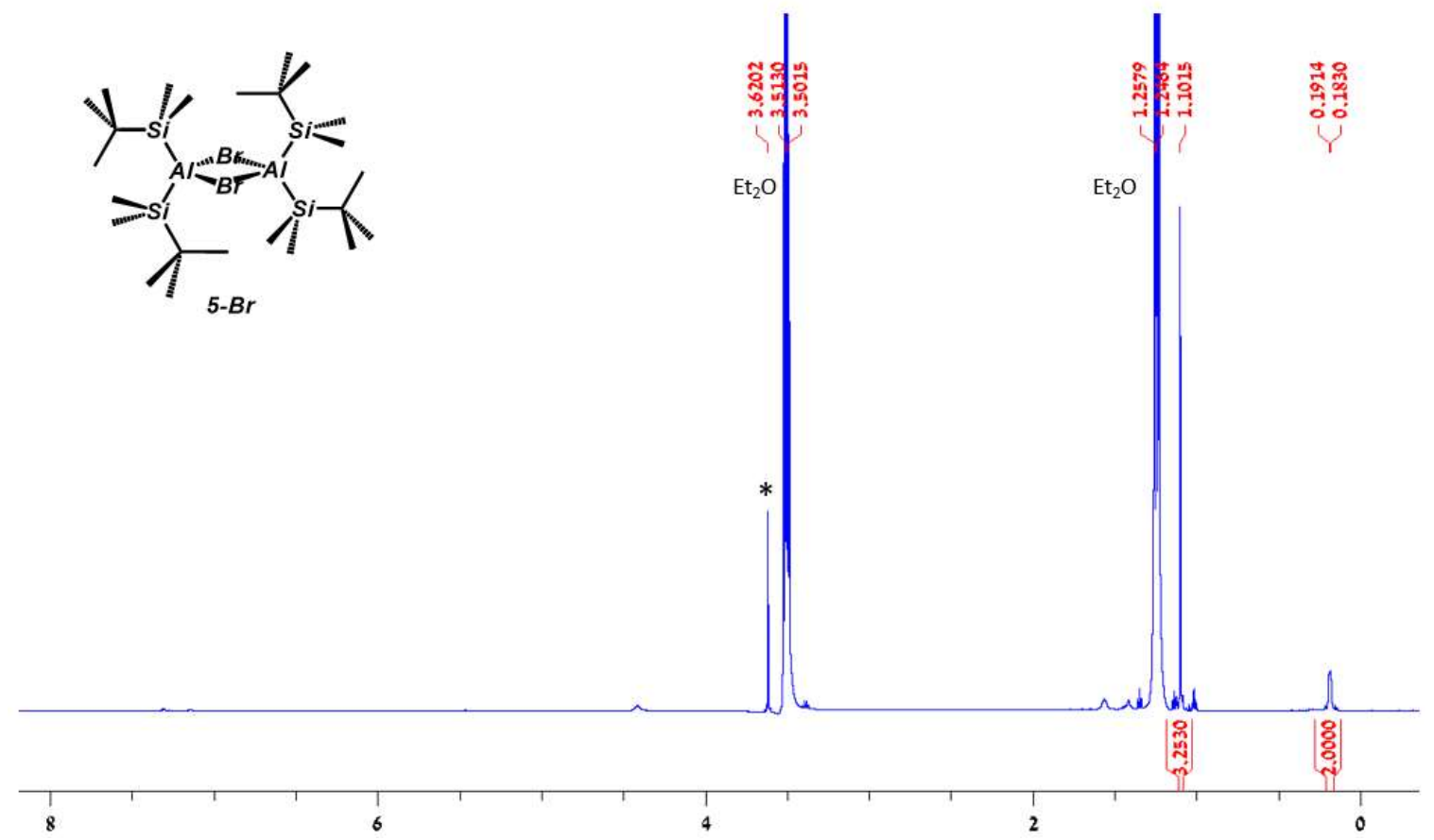

Figure S28. ${ }^{1} \mathrm{H}$ NMR of 5-Br in $\mathrm{Et}_{2} \mathrm{O}$ (*: traces of $\mathrm{H}_{2} \mathrm{O}$ in DMSO- $d_{6}$ capillary). 


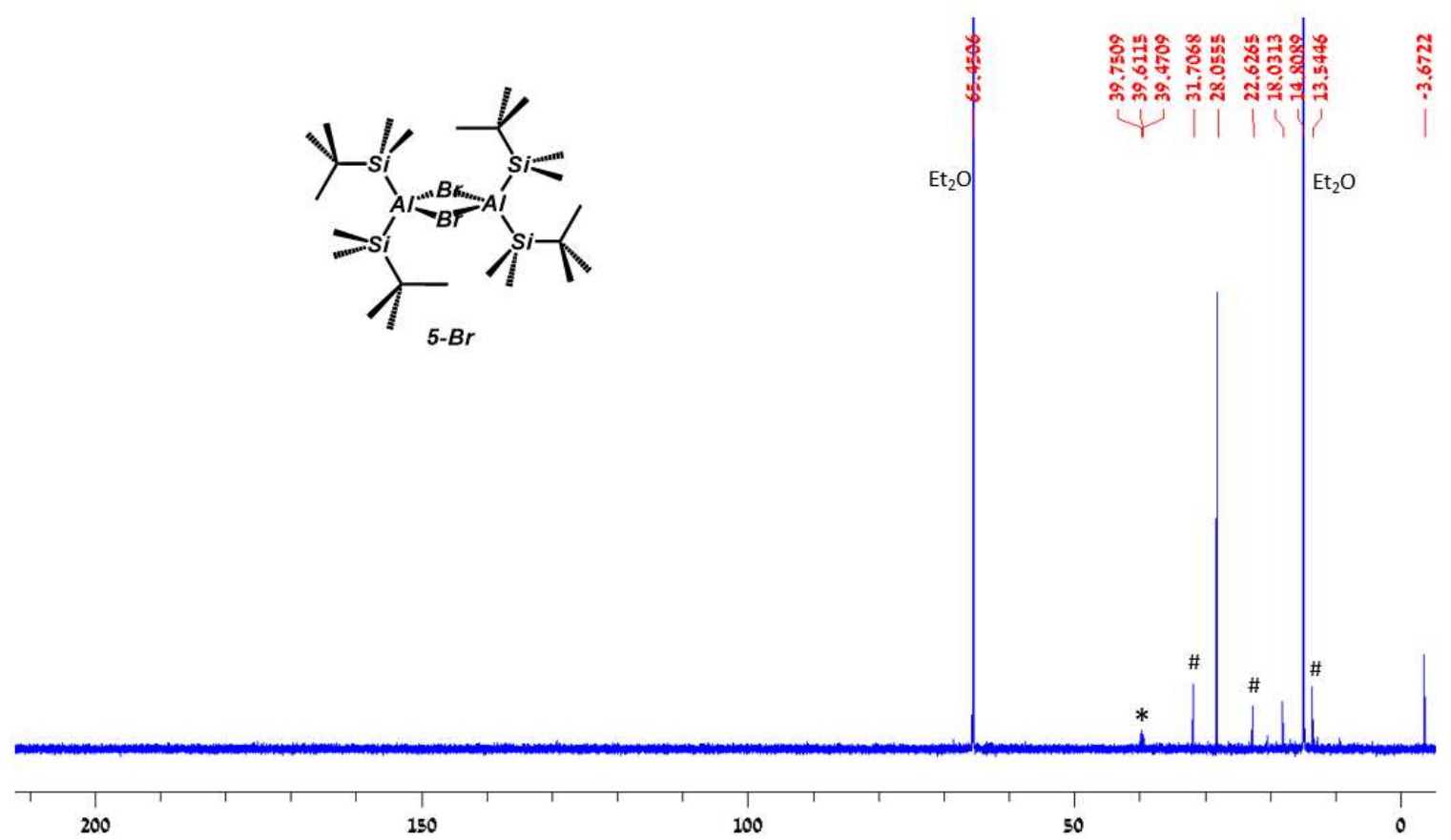

Figure S29. ${ }^{13} \mathrm{C}$ NMR of 5-Br in $\mathrm{Et}_{2} \mathrm{O}$ (\#: hexane; *: DMSO- $d_{6}$ capillary).
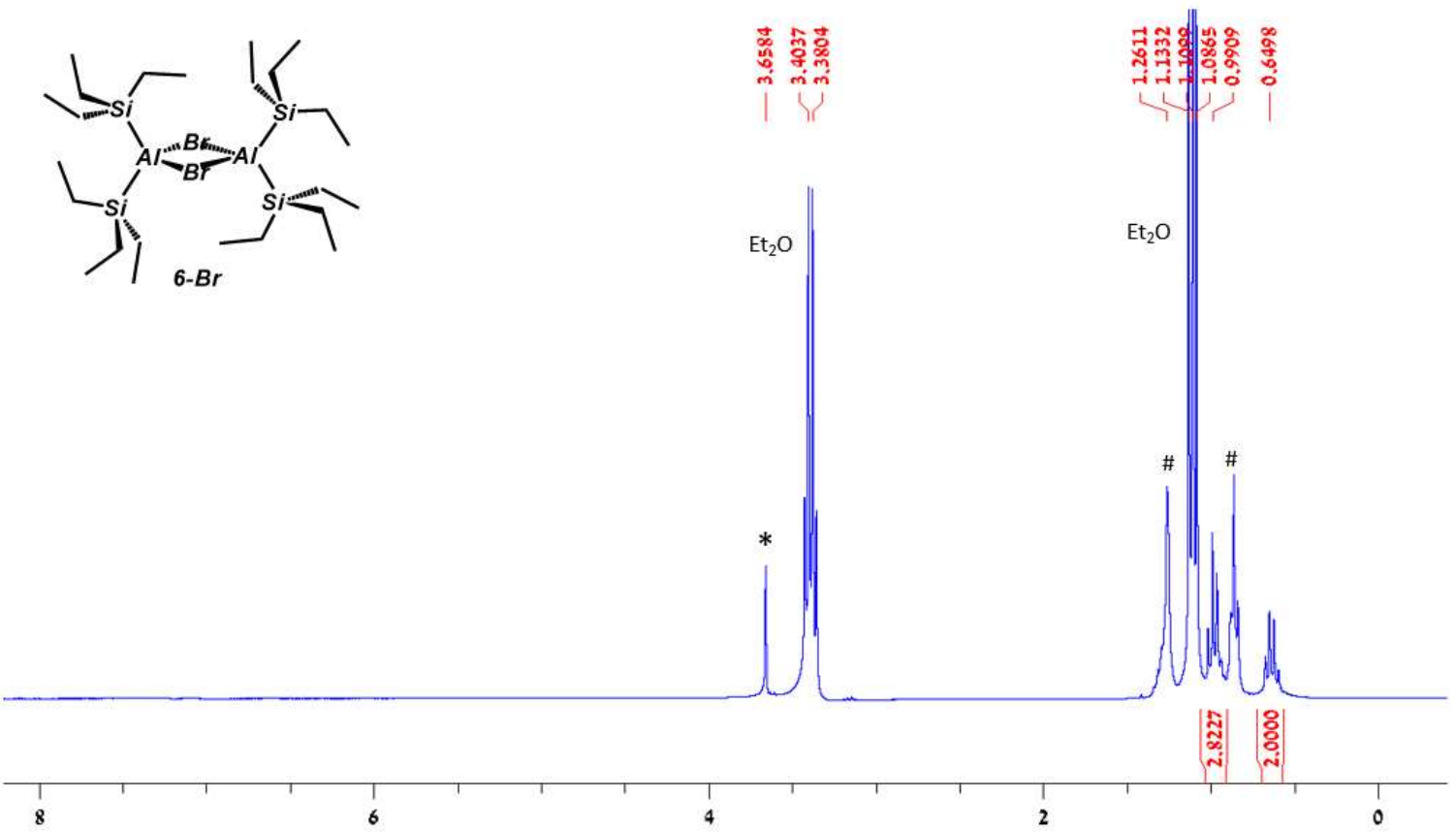

Figure S30. ${ }^{1} \mathrm{H}$ NMR of 6-Br in $\mathrm{Et}_{2} \mathrm{O} /$ hexane (\#: hexane *: traces of $\mathrm{H}_{2} \mathrm{O}$ in DMSO- $d_{6}$ capillary). 


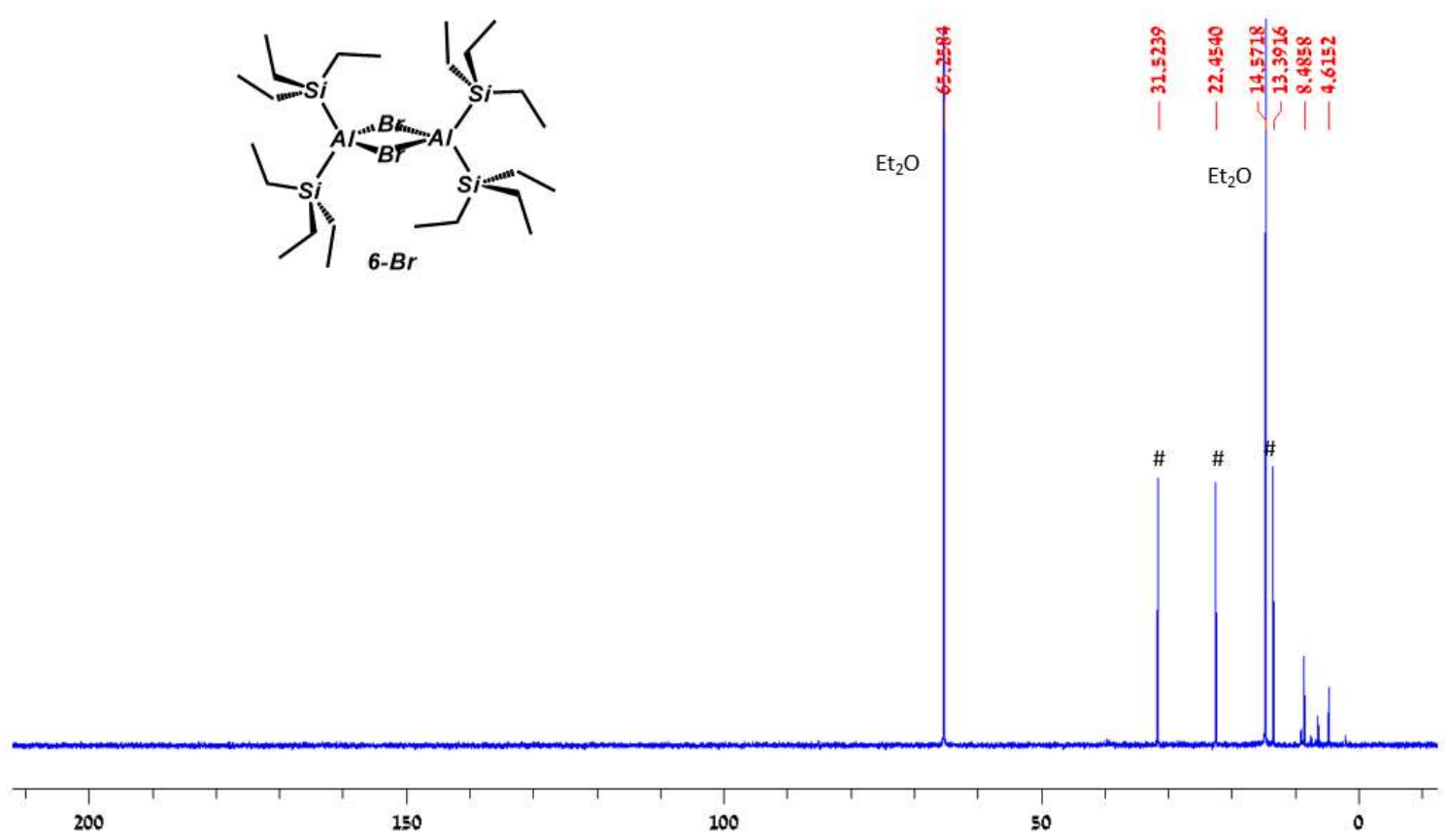

Figure $\mathrm{S} 31 .{ }^{13} \mathrm{C}$ NMR of 6-Br in $\mathrm{Et}_{2} \mathrm{O}$ (\#: hexane).

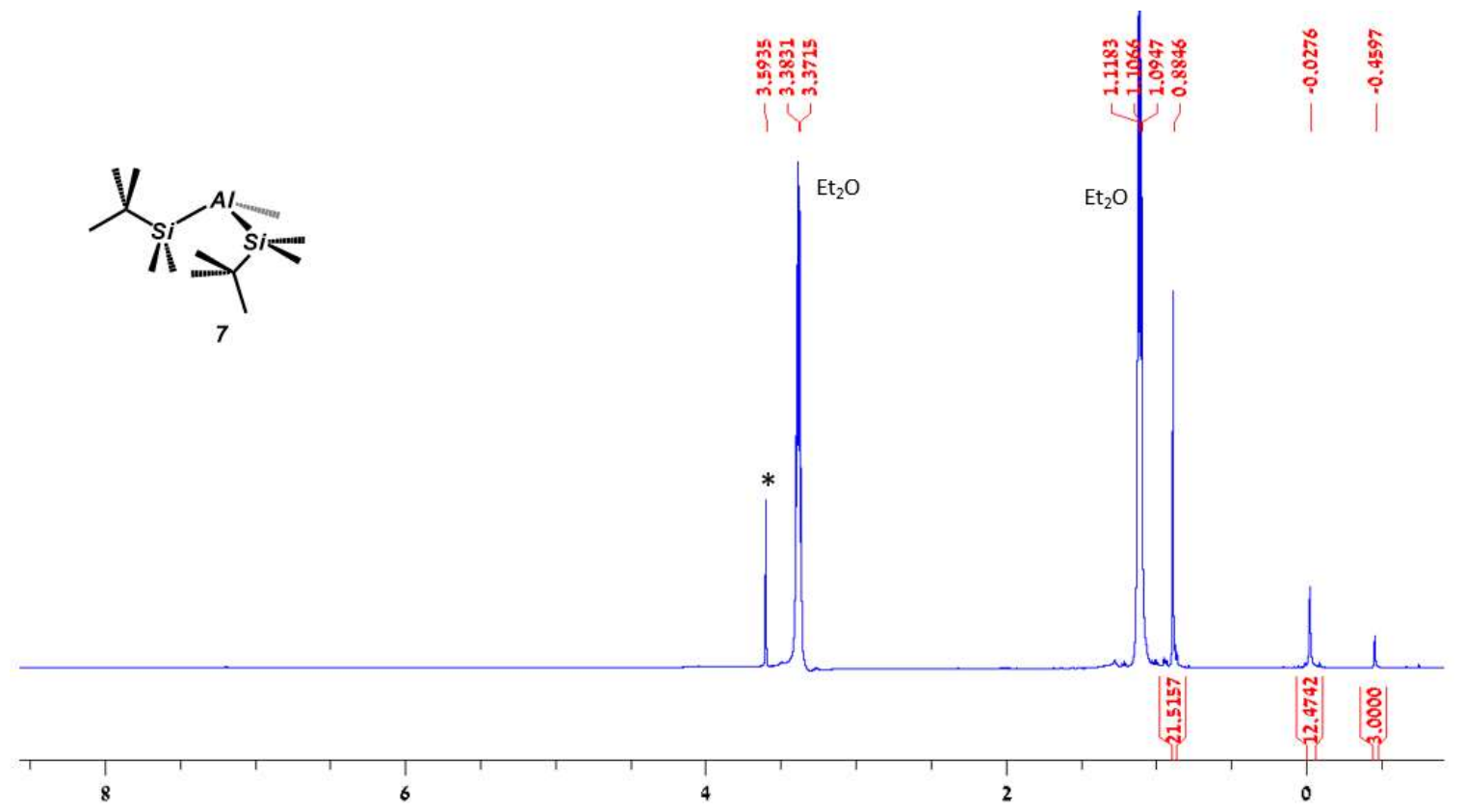

Figure S32. ${ }^{1} \mathrm{H}$ NMR of 7 in $\mathrm{Et}_{2} \mathrm{O}$ (*: traces of $\mathrm{H}_{2} \mathrm{O}$ in DMSO-d ${ }_{6}$ capillary). 


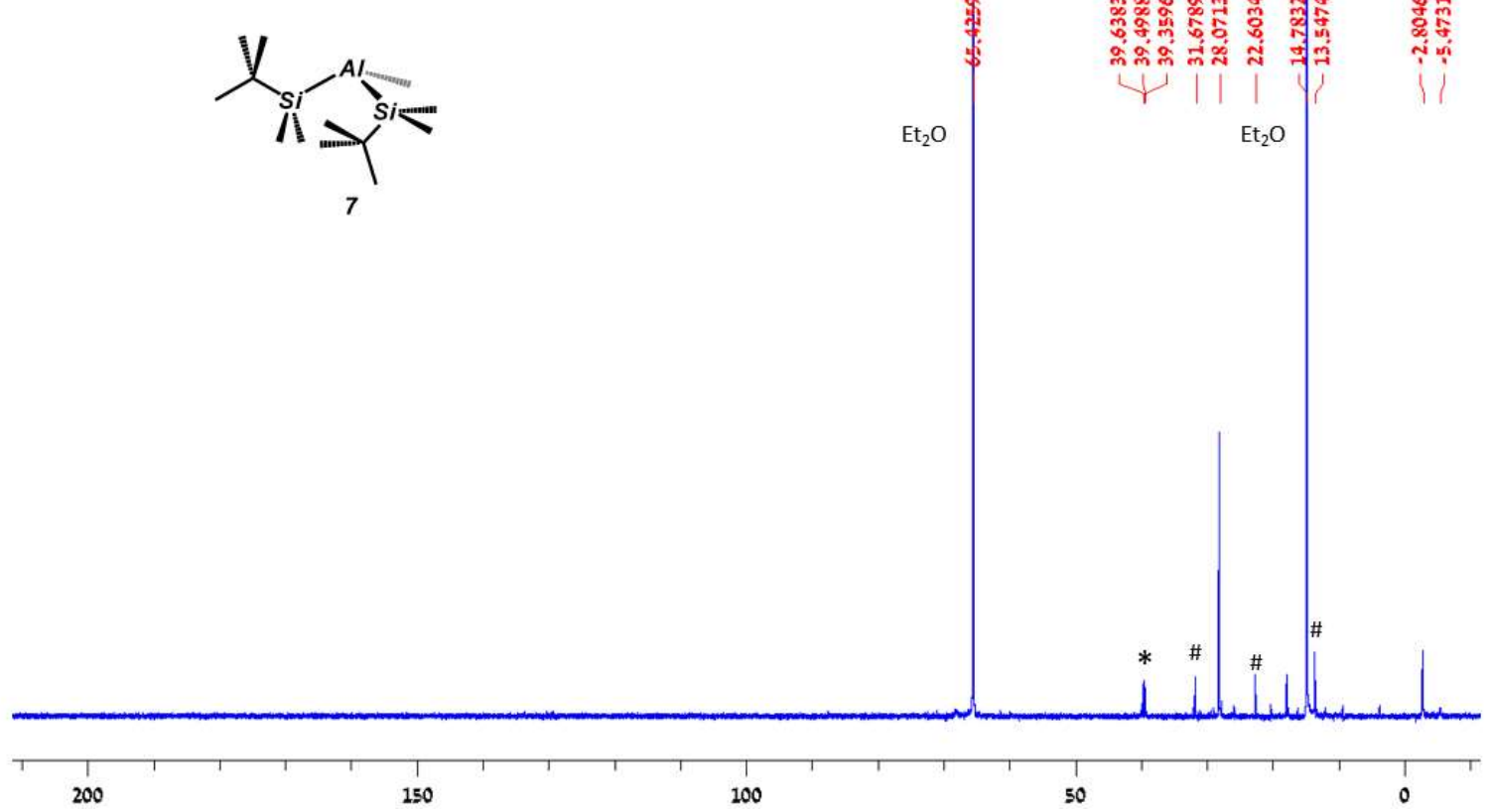

Figure S33. ${ }^{13} \mathrm{C}$ NMR of 7 in $\mathrm{Et}_{2} \mathrm{O}$ (\#: hexane; *: DMSO- $d_{6}$ capillary).

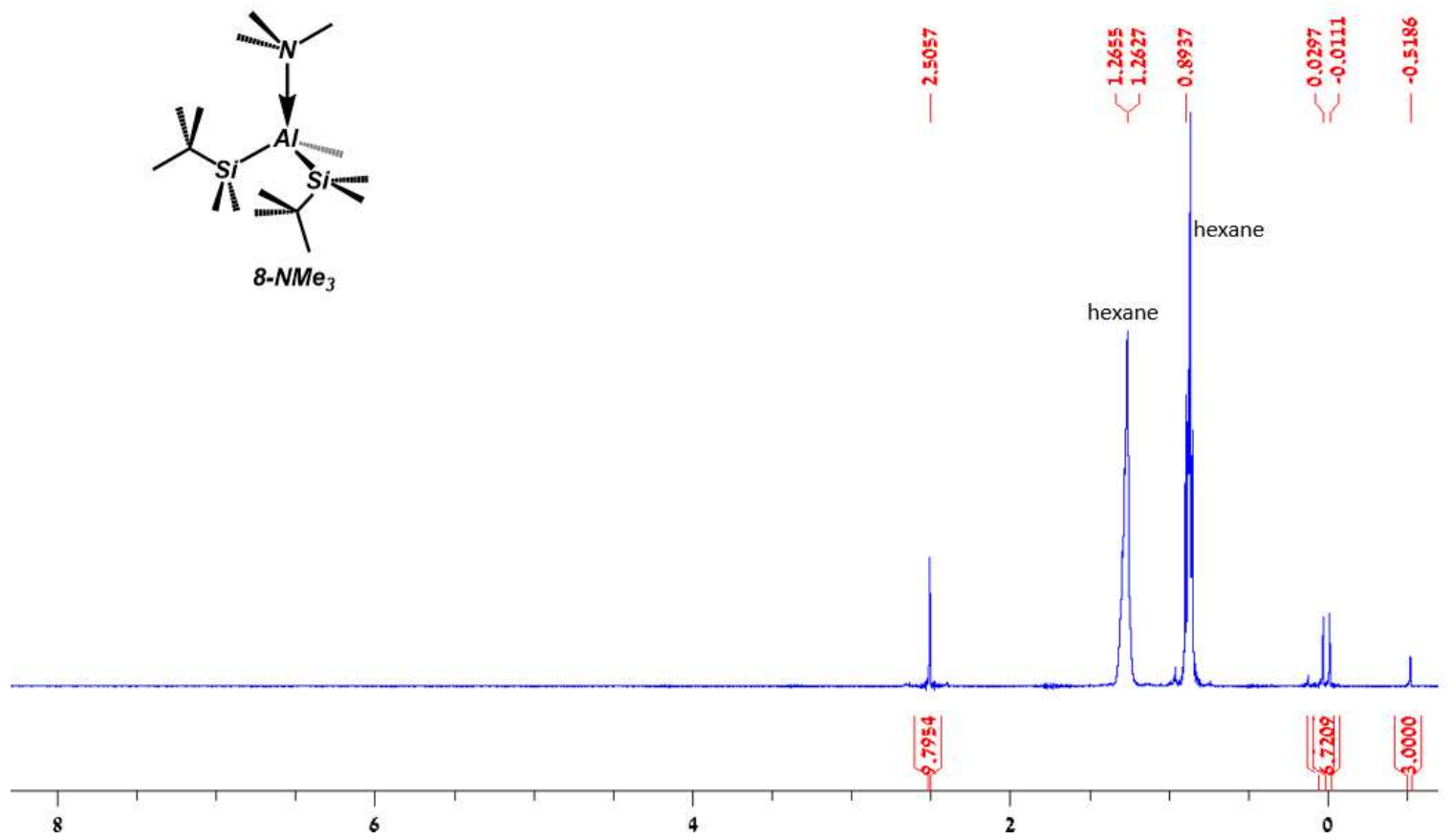

Figure S34. ${ }^{1} \mathrm{H}$ NMR of $\mathbf{8 - N M e}$ in hexane. 


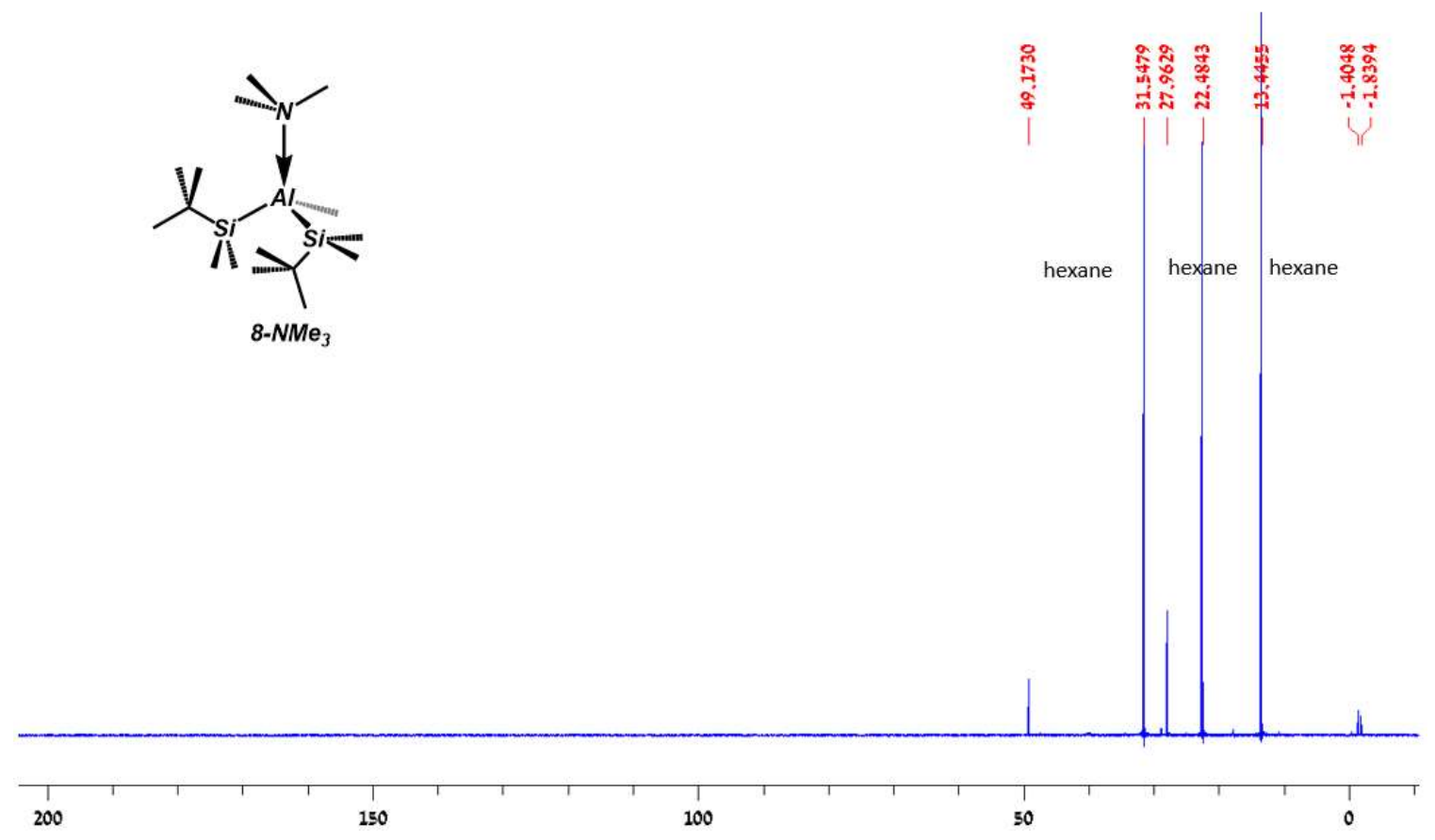

Figure S35. ${ }^{13} \mathrm{C}$ NMR of 8-NMe3 in hexane.

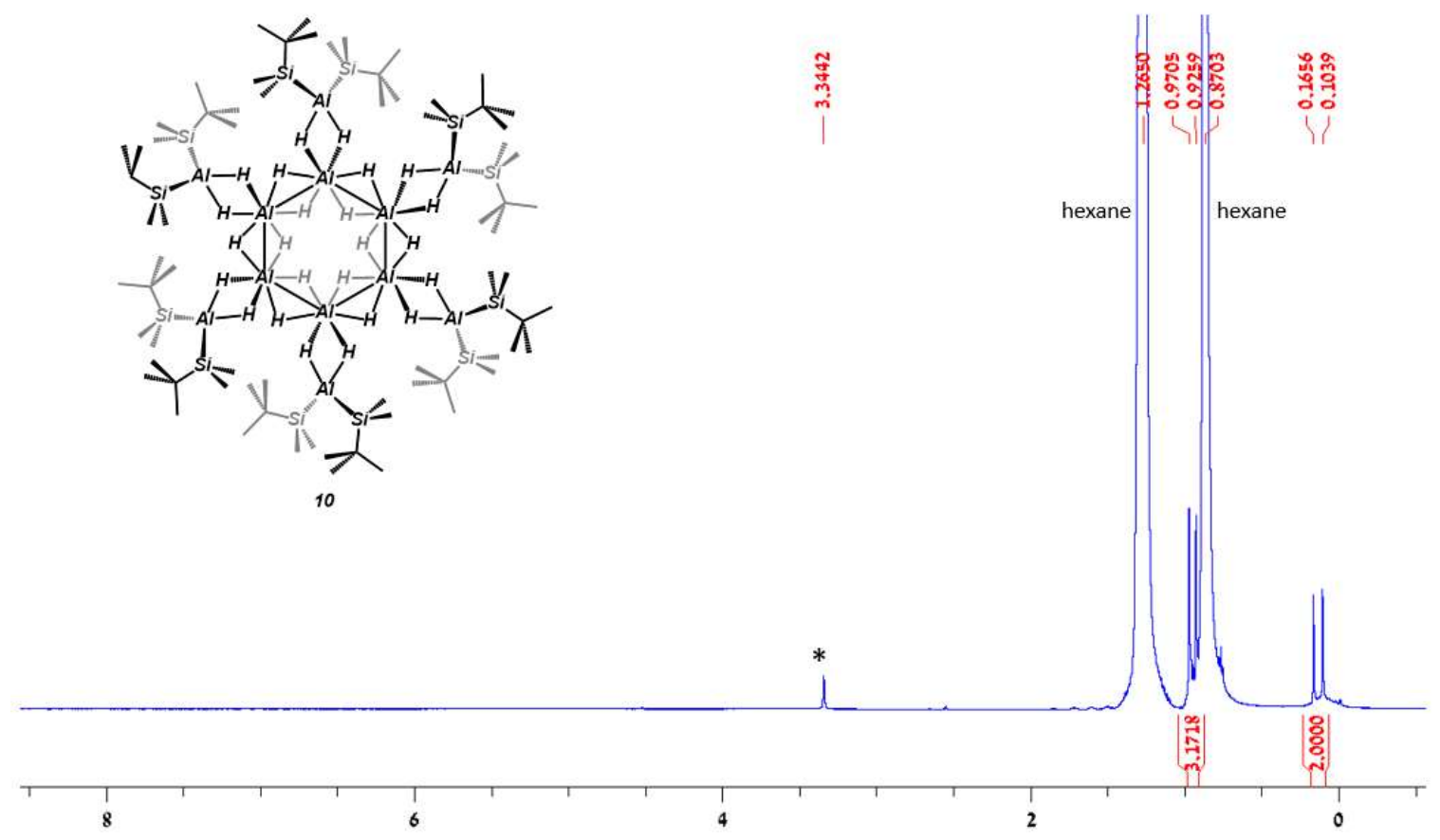

Figure S36. ${ }^{1} \mathrm{H}$ NMR of $\mathbf{1 0}$ in hexane (*: traces of $\mathrm{H}_{2} \mathrm{O}$ in DMSO- $d_{6}$ capillary). 


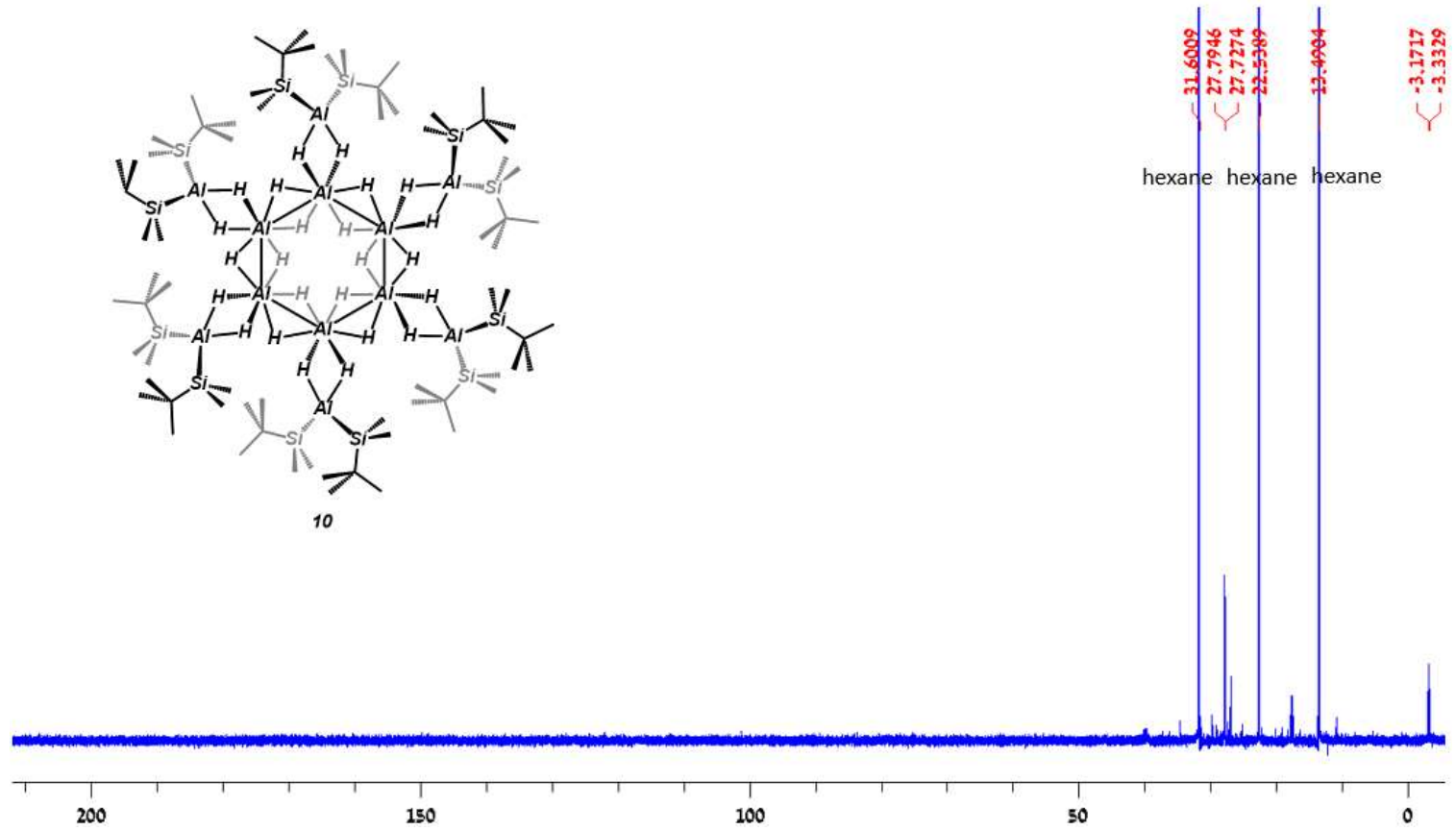

Figure S37. ${ }^{13} \mathrm{C}$ NMR of $\mathbf{1 0}$ in hexane.

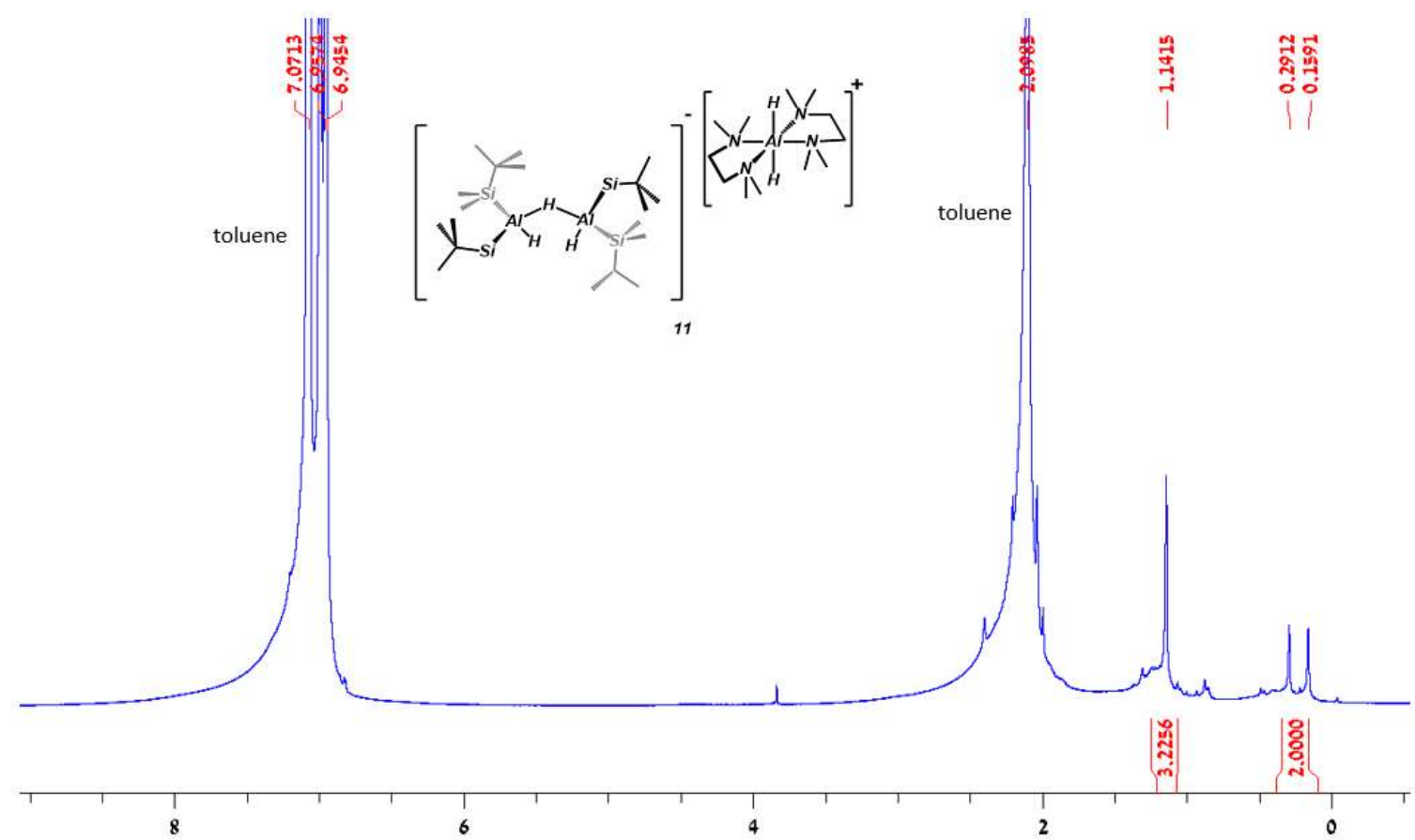

Figure S38. ${ }^{1} \mathrm{H}$ NMR of $\mathbf{1 1}$ in toluene. 


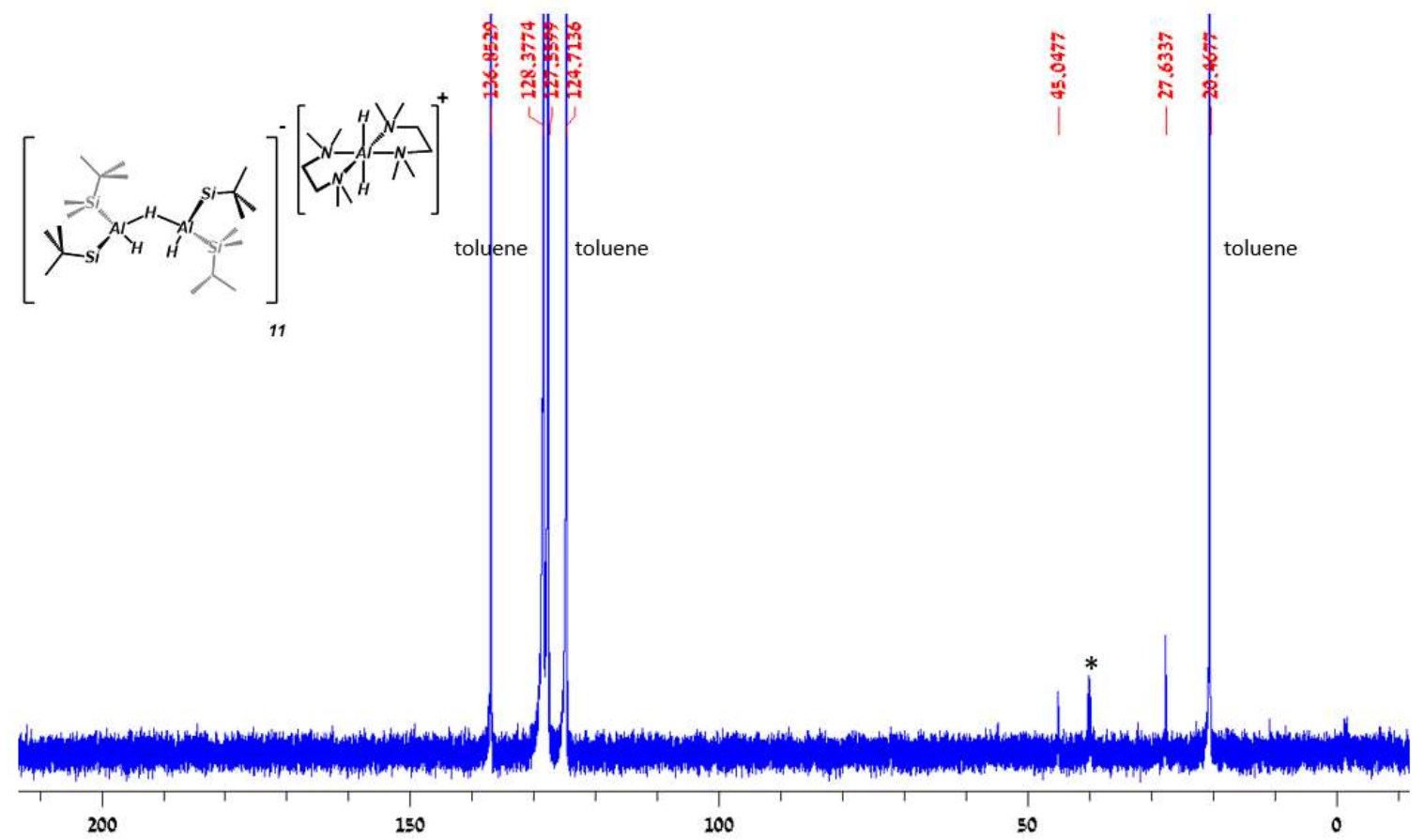

Figure S39. ${ }^{13} \mathrm{C}$ NMR of 11 in toluene (*: DMSO- $d_{6}$ capillary).

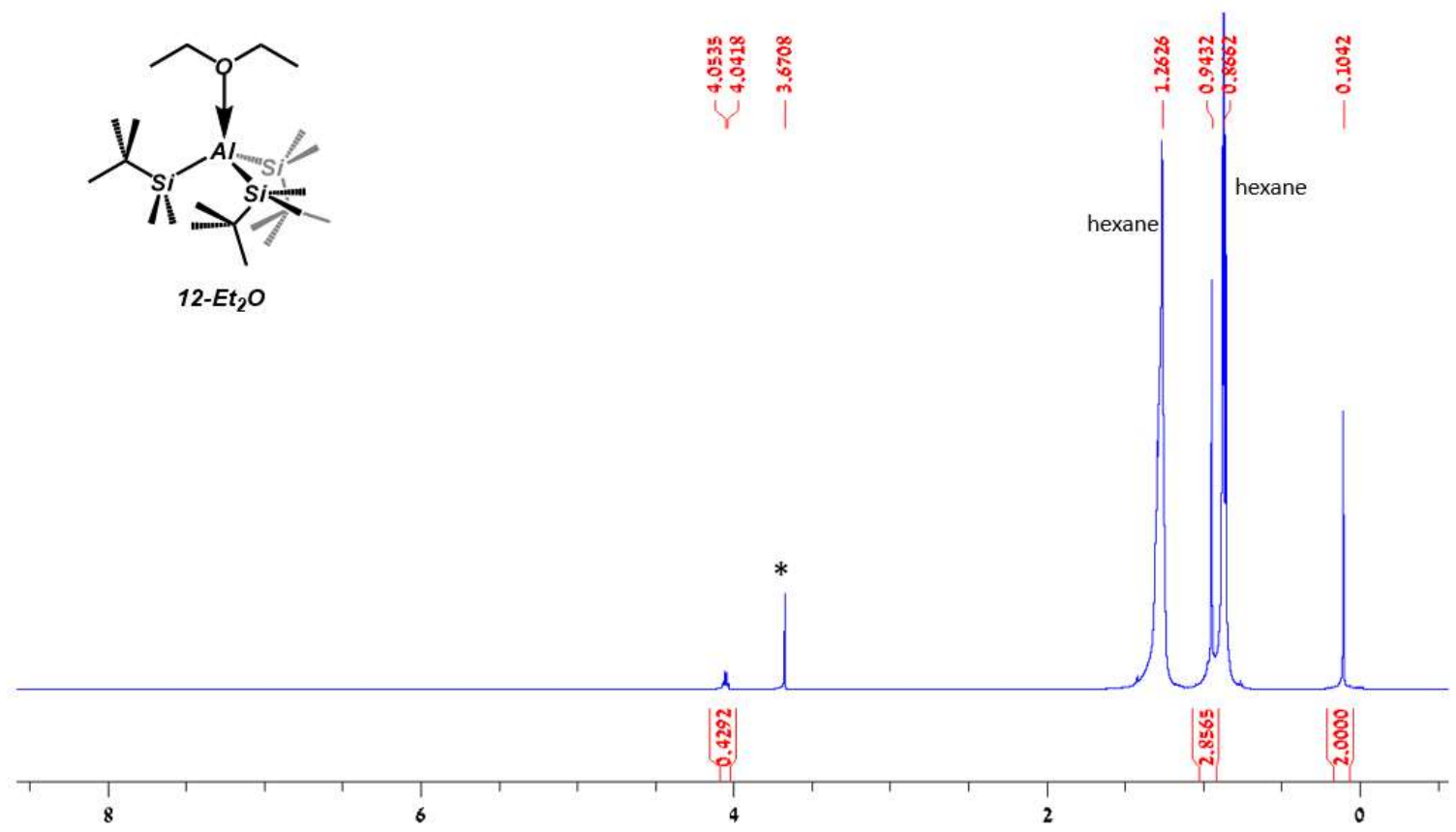

Figure S40. ${ }^{1} \mathrm{H}$ NMR of 12-Et $\mathbf{t}_{2} \mathrm{O}$ in hexane (*: traces of $\mathrm{H}_{2} \mathrm{O}$ in DMSO- $d_{6}$ capillary). 


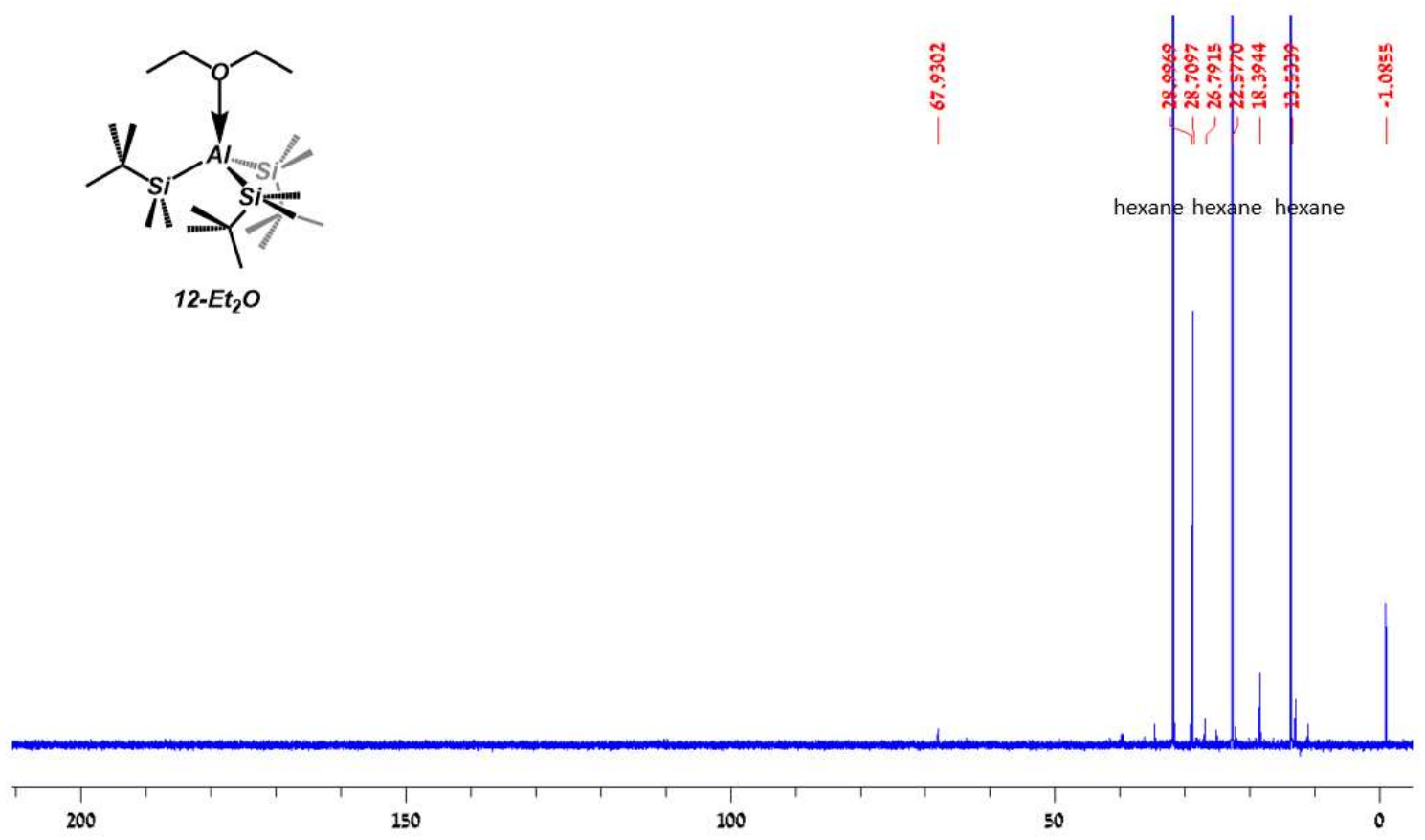

Figure S41. ${ }^{13} \mathrm{C}$ NMR of 12-Et $\mathbf{2} \mathbf{O}$ in hexane.

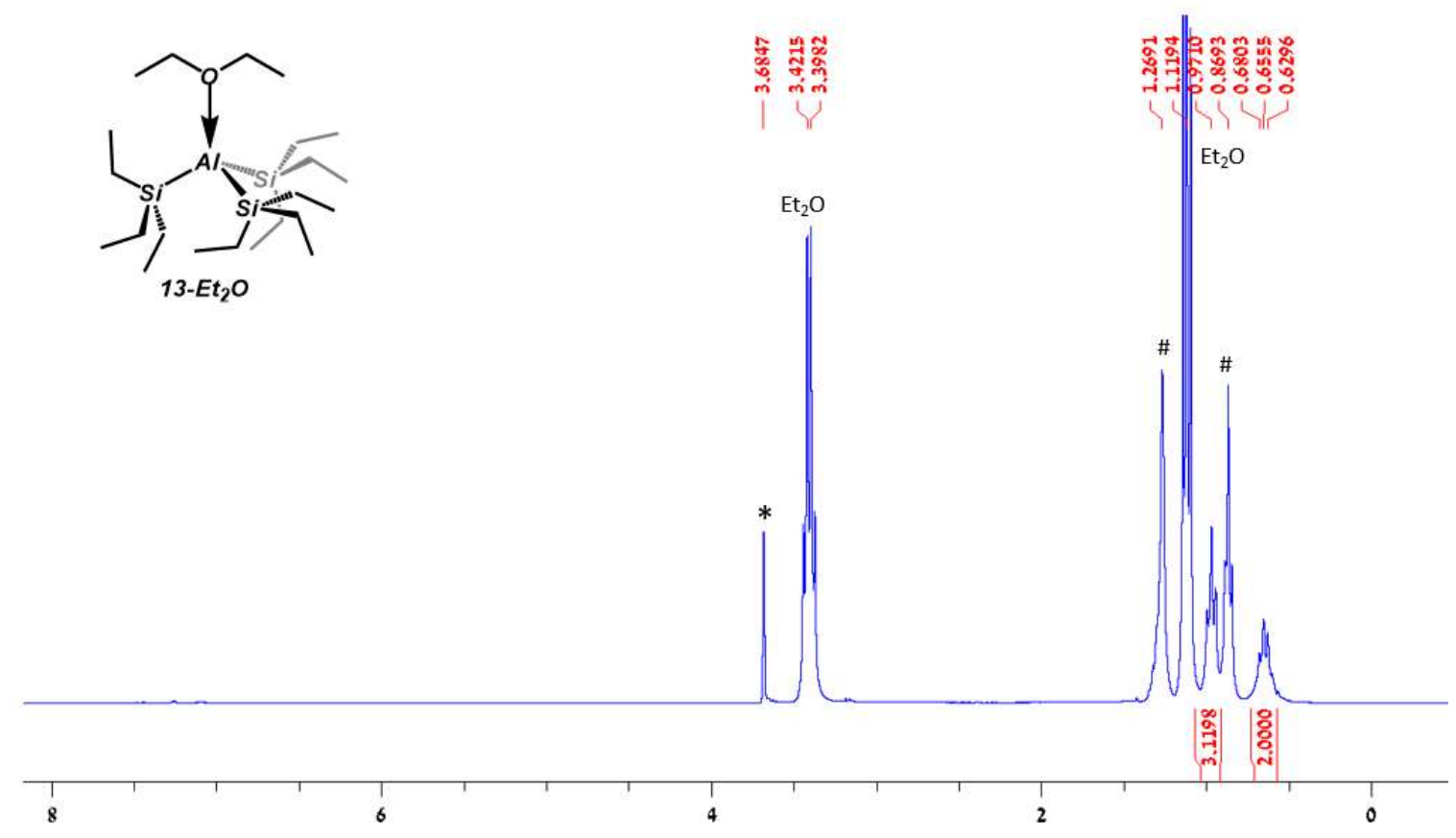

Figure S42. ${ }^{1} \mathrm{H}$ NMR of 13-Et $2 \mathrm{O}$ in $\mathrm{Et}_{2} \mathrm{O} /$ hexane (\#: hexane; *: traces of $\mathrm{H}_{2} \mathrm{O}$ in DMSO$d_{6}$ capillary). 

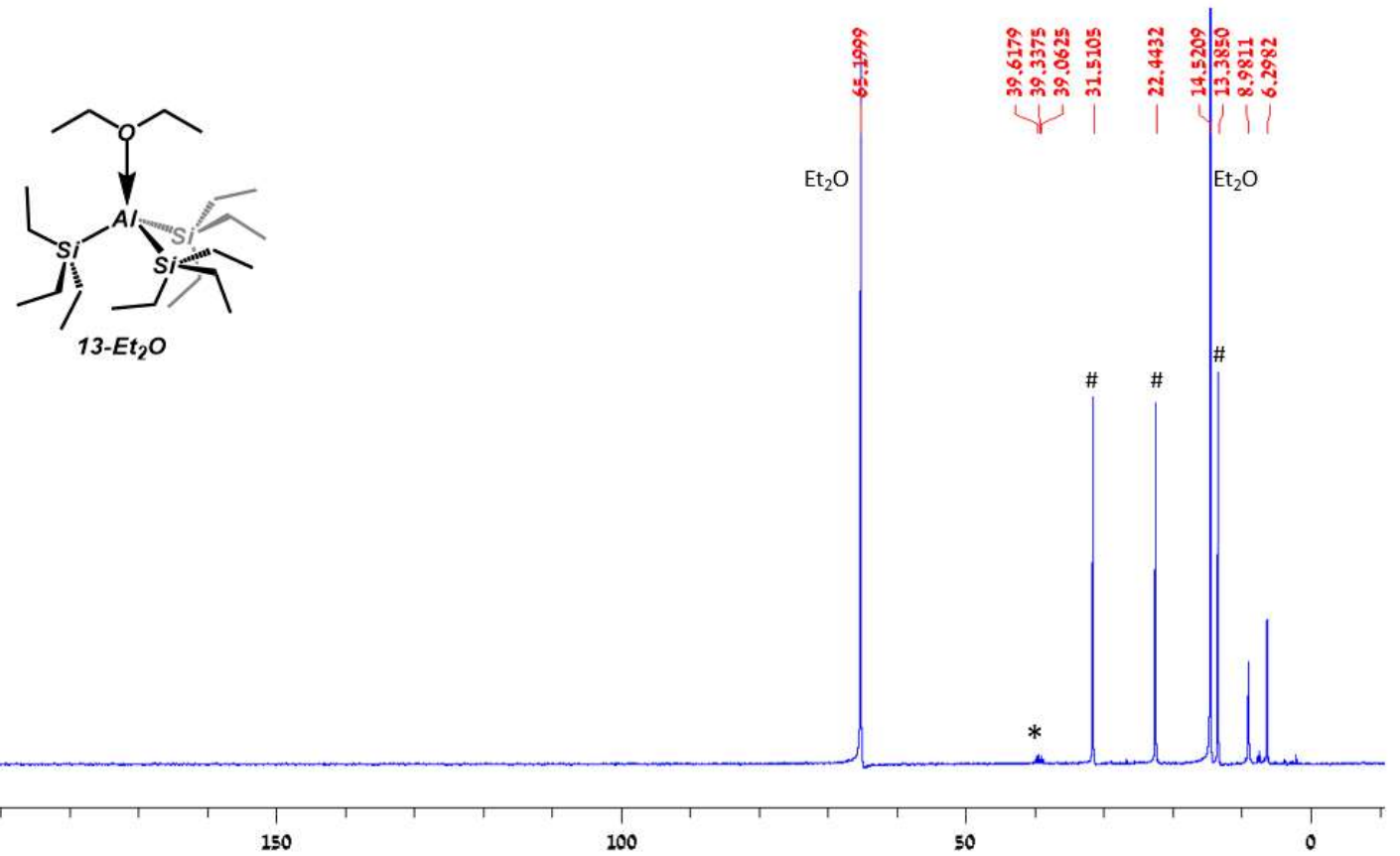

Figure S43. ${ }^{13} \mathrm{C}$ NMR of 13-Et $2 \mathrm{O}$ in $\mathrm{Et}_{2} \mathrm{O} /$ hexane (\#: hexane; *: DMSO- $d_{6}$ capillary).

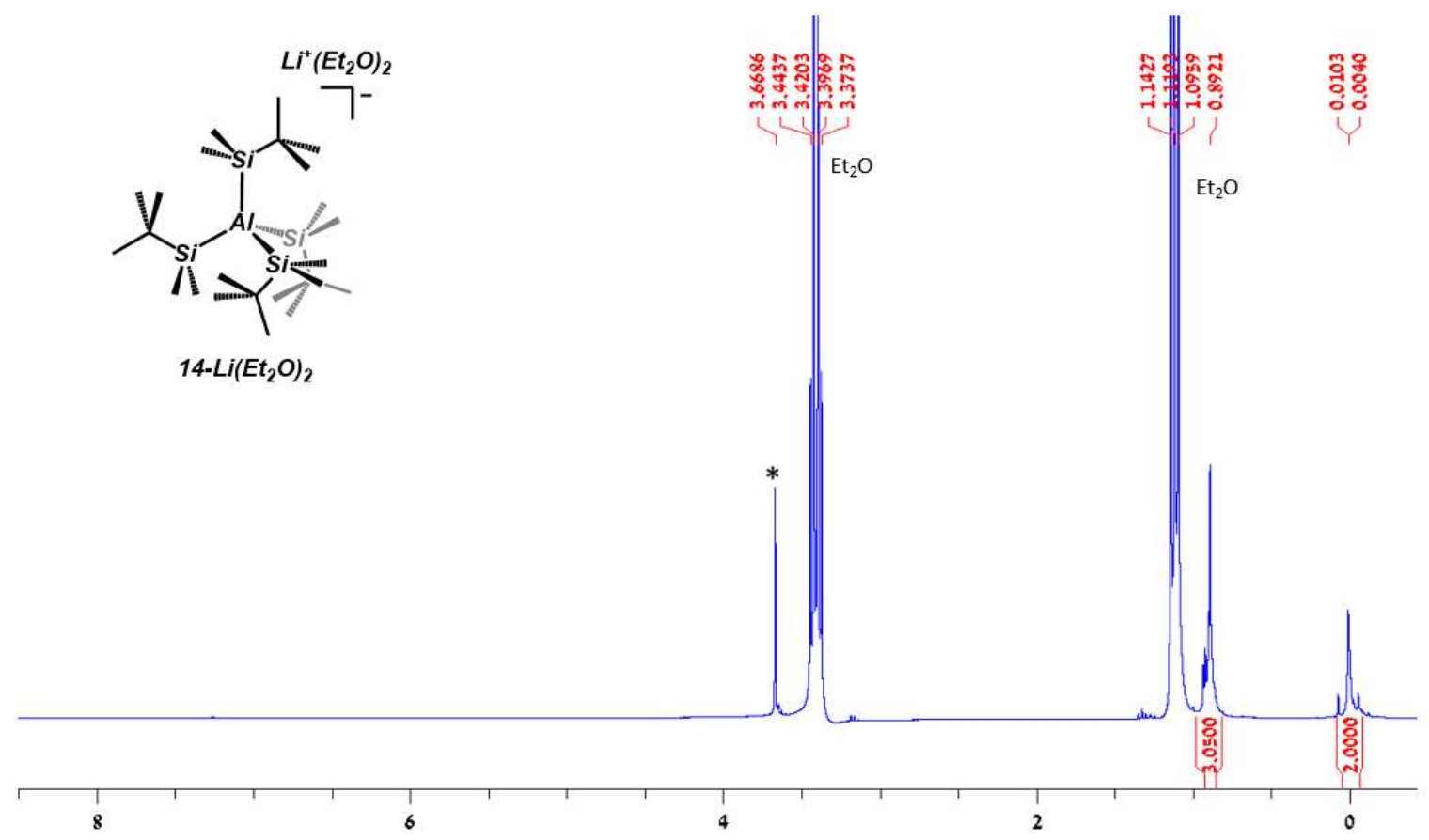

Figure S44. ${ }^{1} \mathrm{H}$ NMR of 14- $\mathbf{L i}\left(\mathbf{E t}_{2} \mathrm{O}\right)_{2}$ in $\mathrm{Et}_{2} \mathrm{O}$ (*: traces of $\mathrm{H}_{2} \mathrm{O}$ in DMSO- $d_{6}$ capillary). 


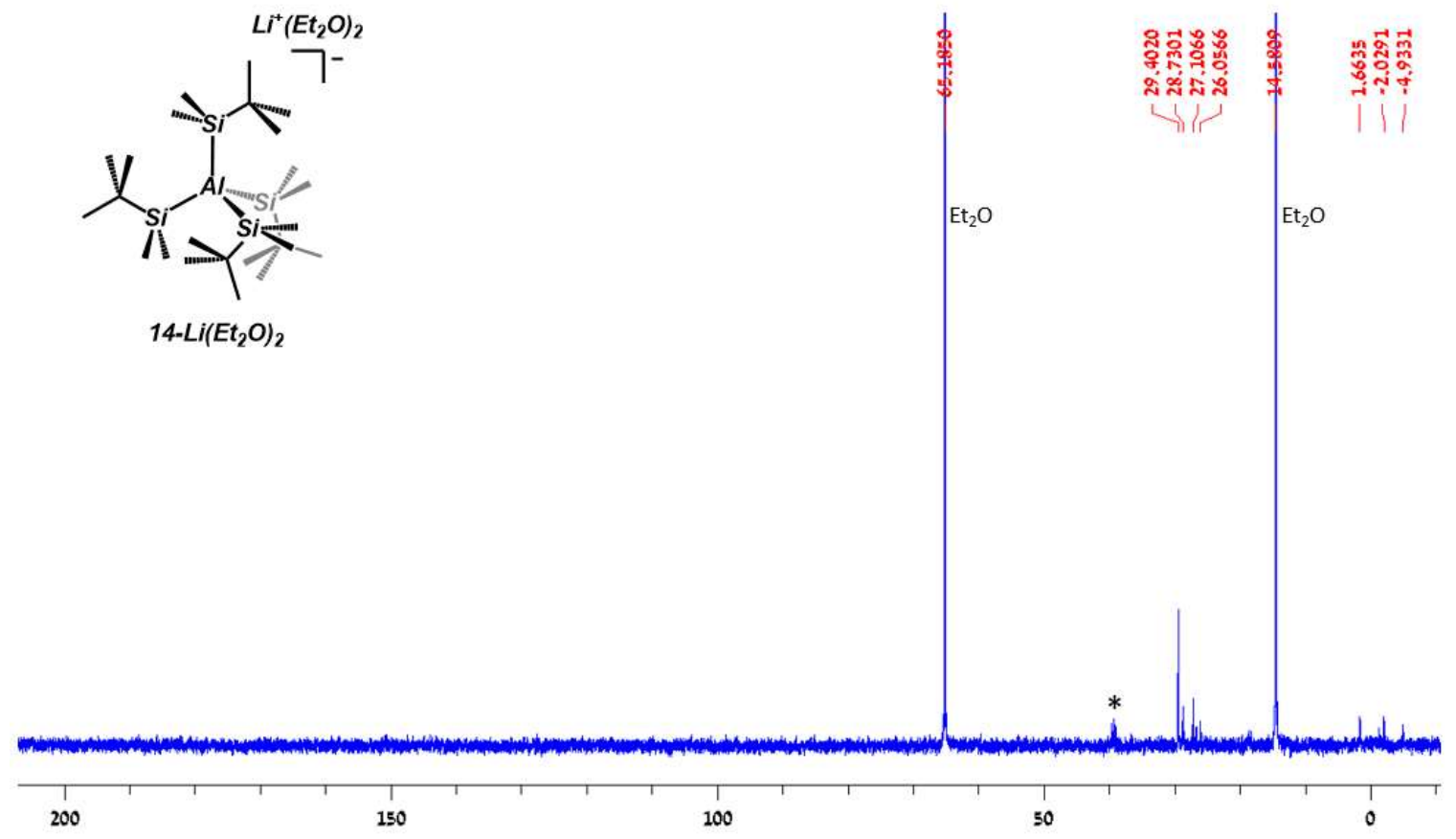

Figure S45. ${ }^{13} \mathrm{C}$ NMR of 14- $\mathbf{L i}\left(\mathbf{E t}_{2} \mathrm{O}\right)_{2}$ in $\mathrm{Et}_{2} \mathrm{O}$ (*: DMSO- $d_{6}$ capillary).

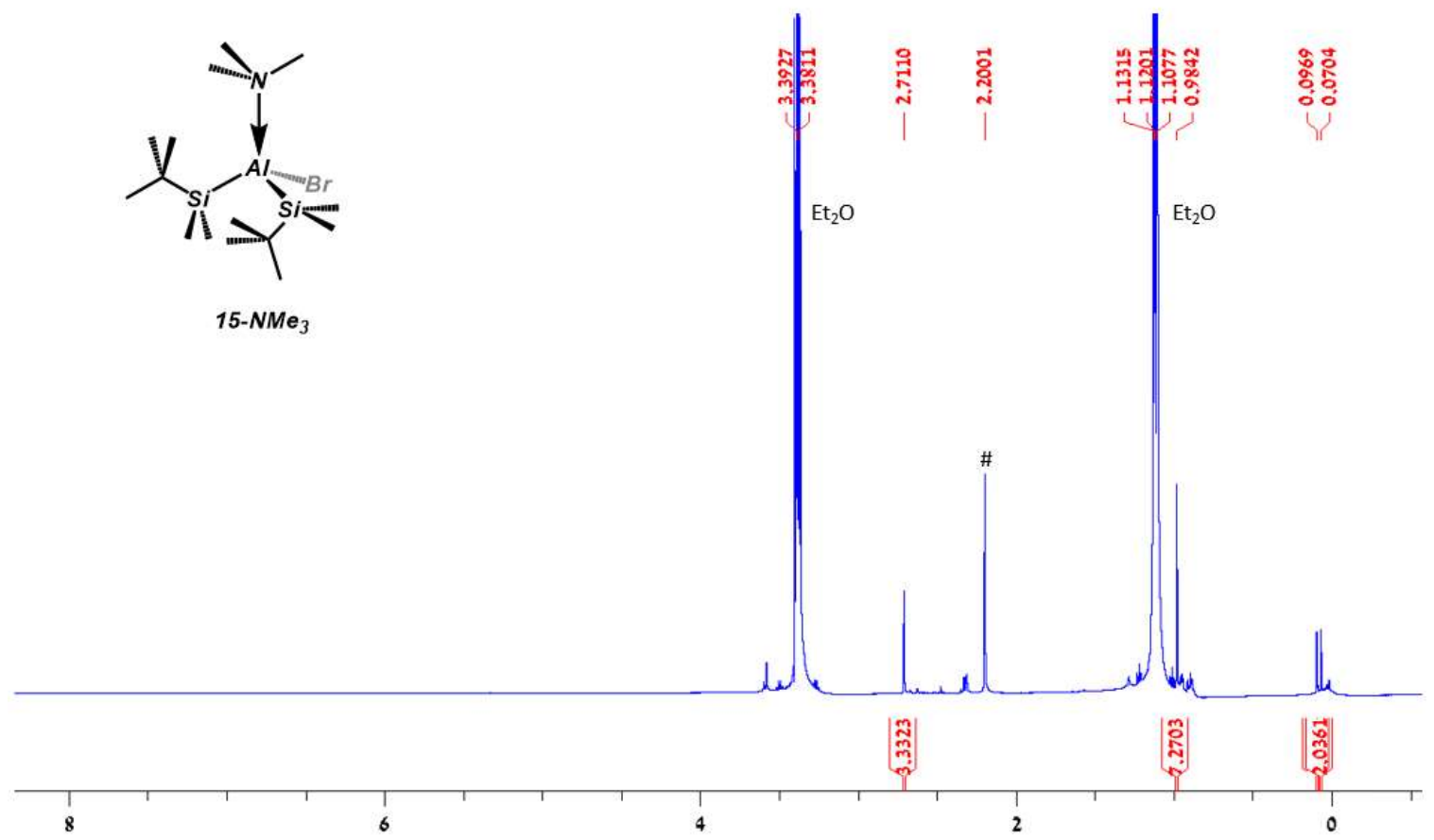

Figure S46. ${ }^{1} \mathrm{H}$ NMR of 15-NMe3 in $\mathrm{Et}_{2} \mathrm{O}$ (\#: traces of $\mathrm{NMe}_{3}$ ). 


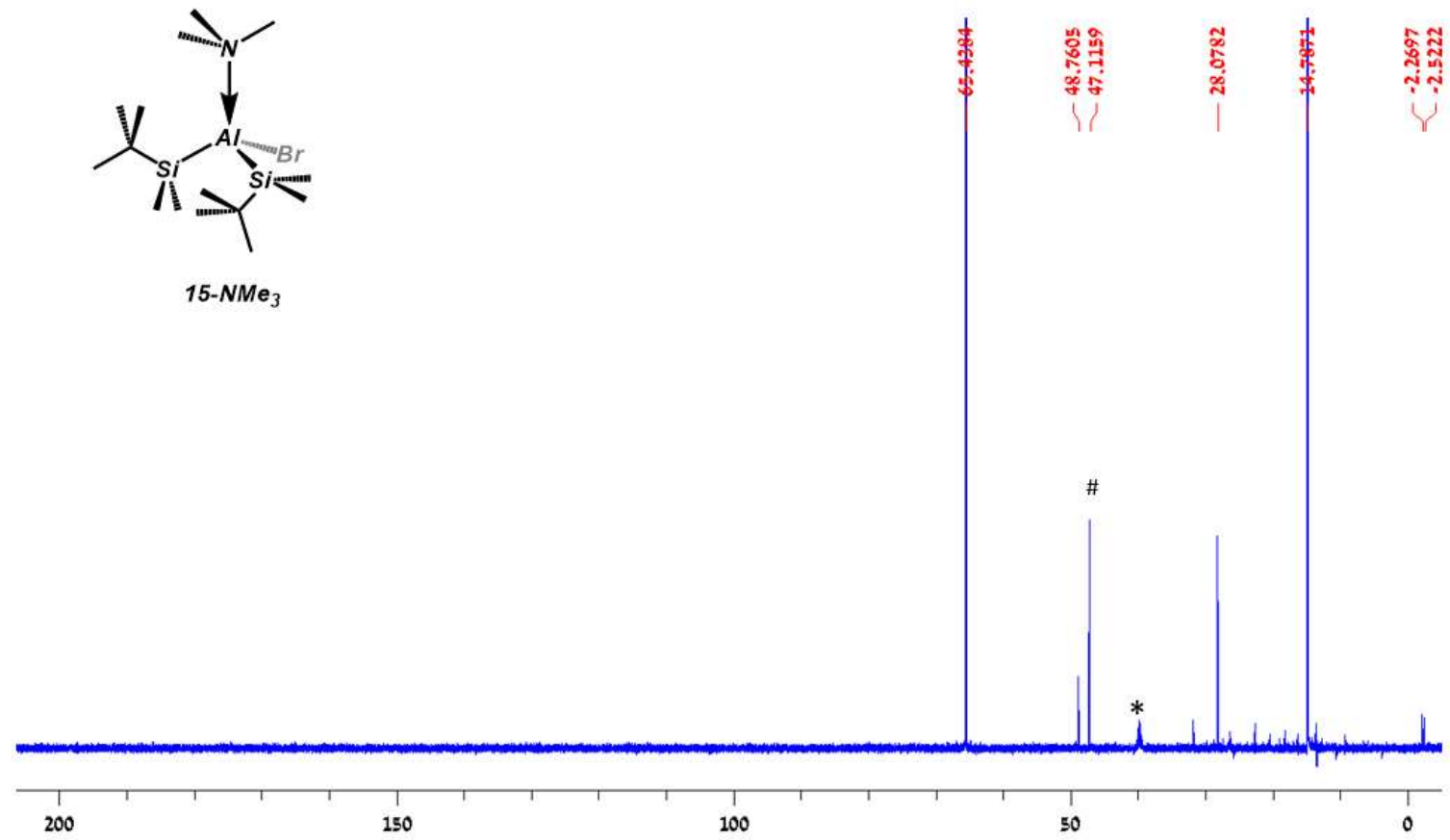

Figure S47. ${ }^{13} \mathrm{C}$ NMR of $\mathbf{1 5}-\mathrm{NMe}_{3}$ in $\mathrm{Et}_{2} \mathrm{O}$ (\#: traces of $\mathrm{NMe}_{3} ; *$ : DMSO- $d_{6}$ capillary).

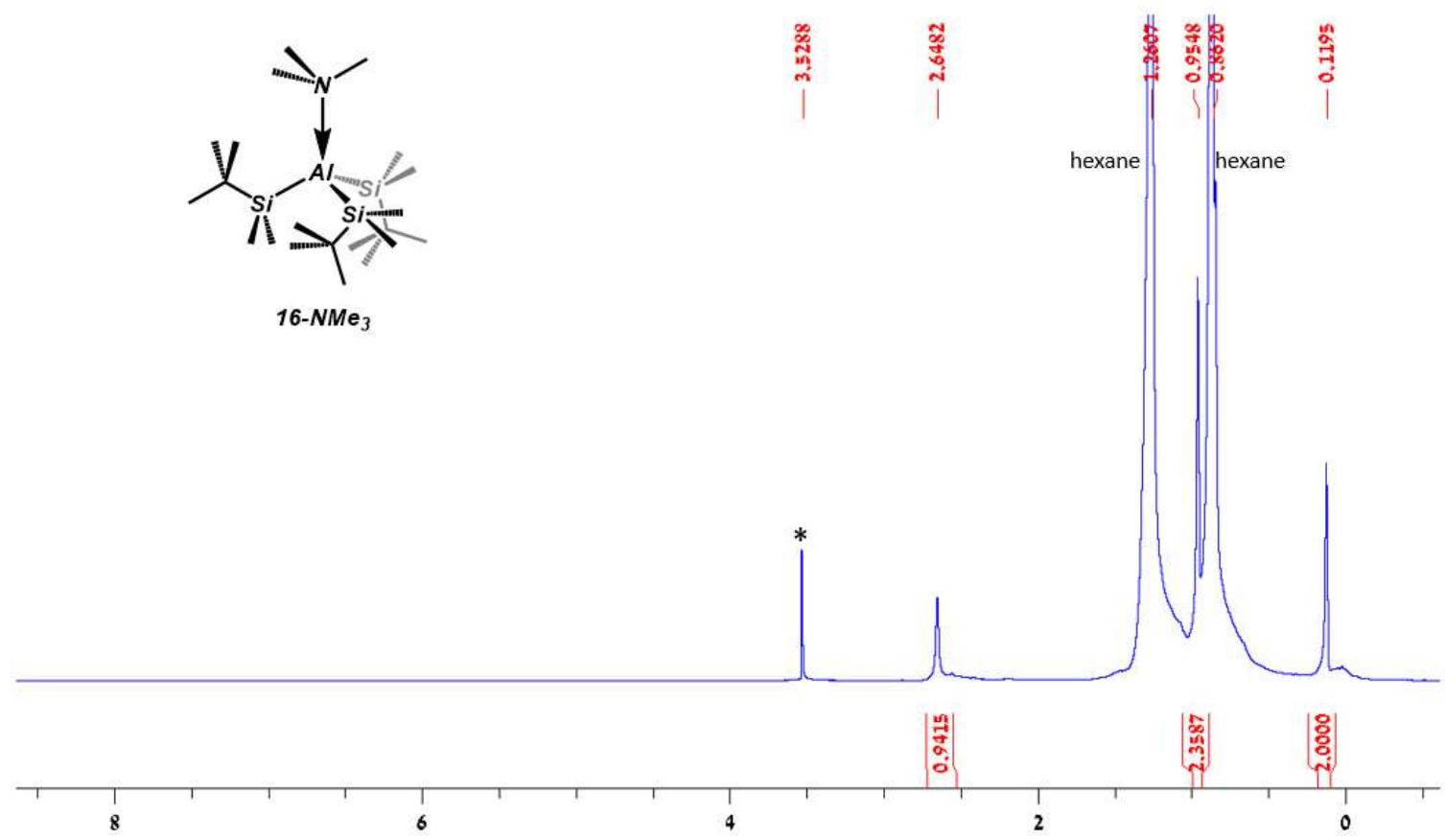

Figure S48. ${ }^{1} \mathrm{H}$ NMR of 16-NMe 3 in hexane (*: traces of $\mathrm{H}_{2} \mathrm{O}$ in DMSO- $d_{6}$ capillary). 


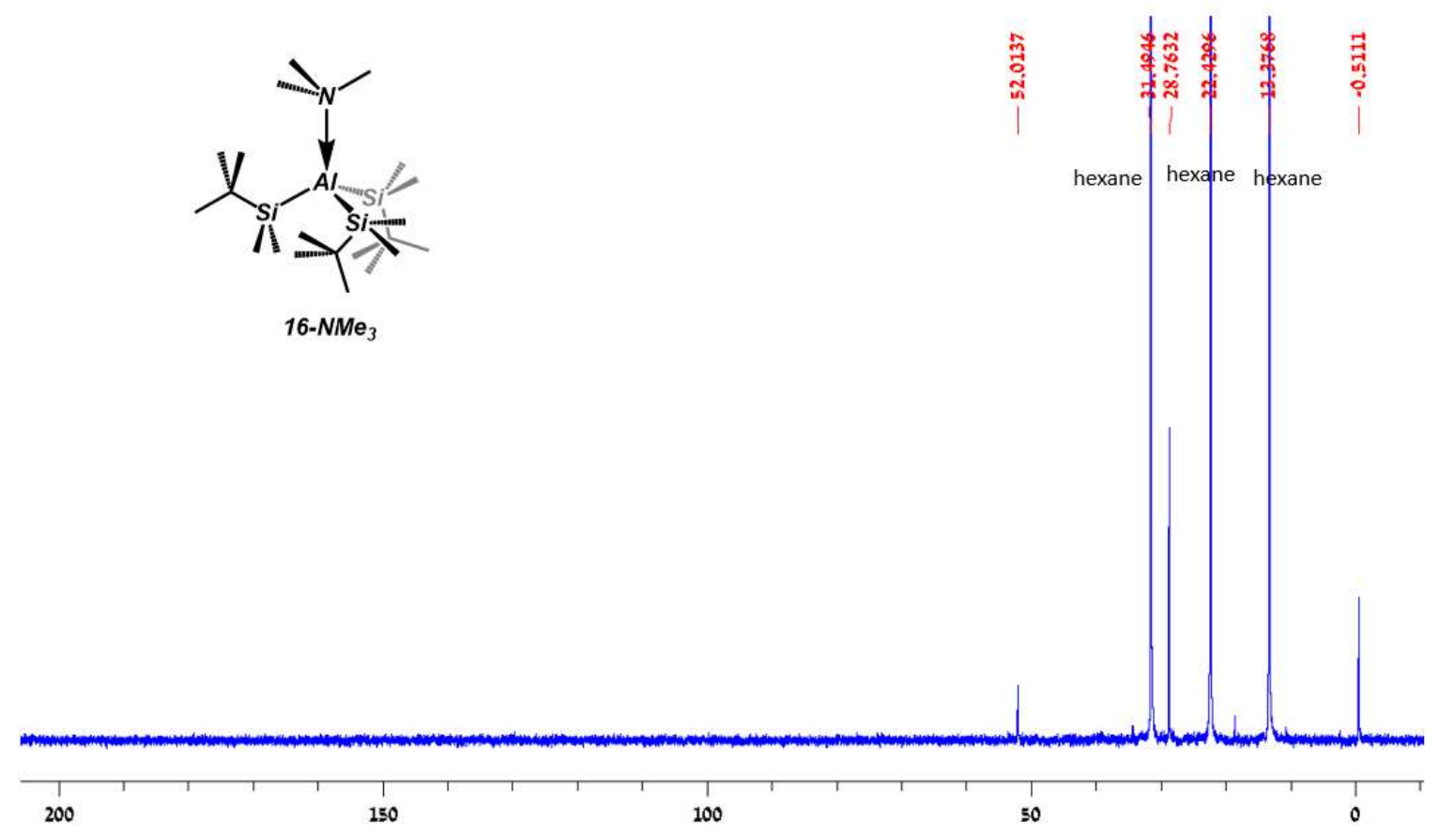

Figure S49. ${ }^{1} \mathrm{H}$ NMR of $\mathbf{1 6 - N M e} 3$ in hexane.

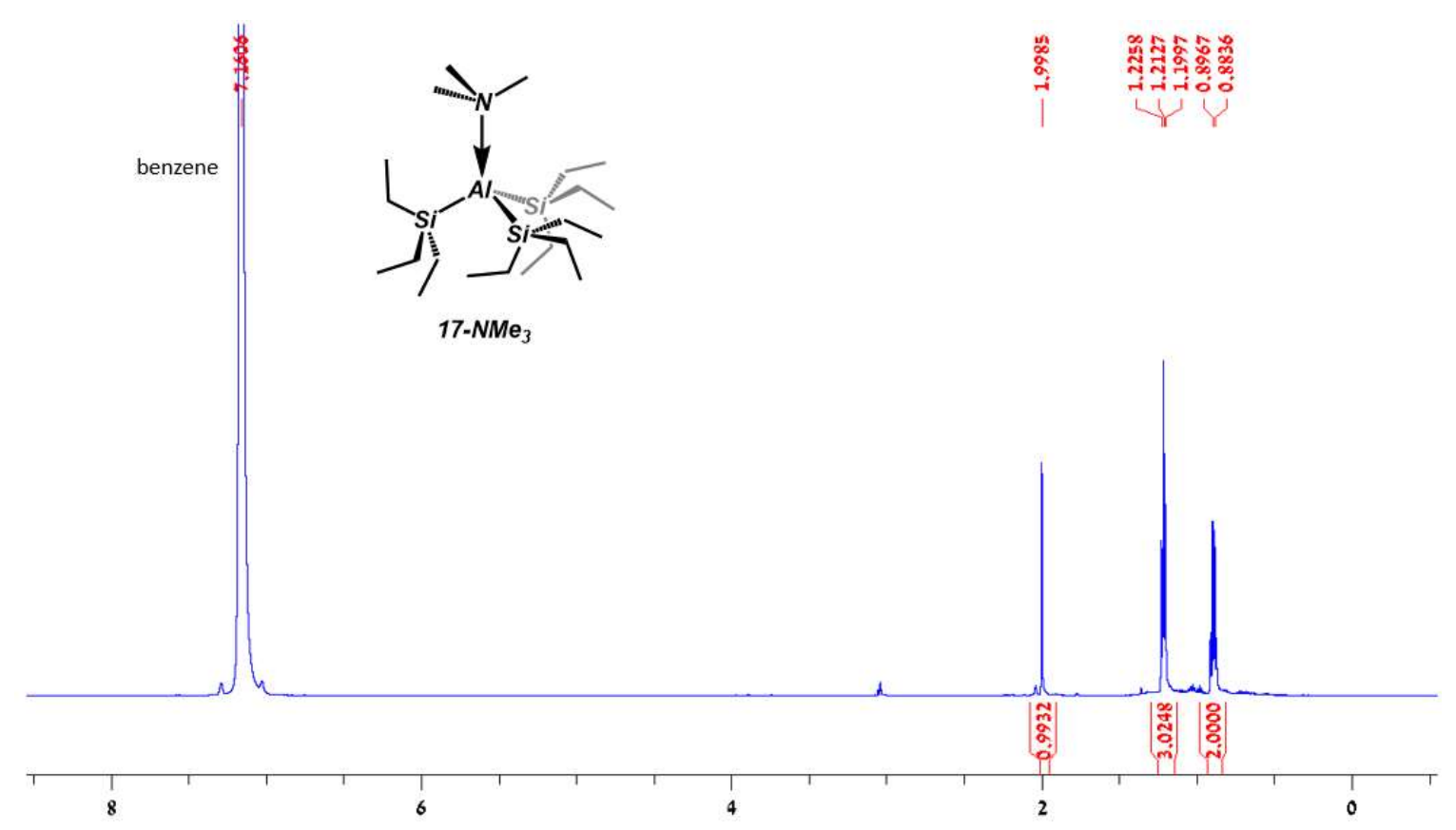

Figure S50. ${ }^{1} \mathrm{H}$ NMR of $\mathbf{1 7 - N M e} 3$ in benzene. 


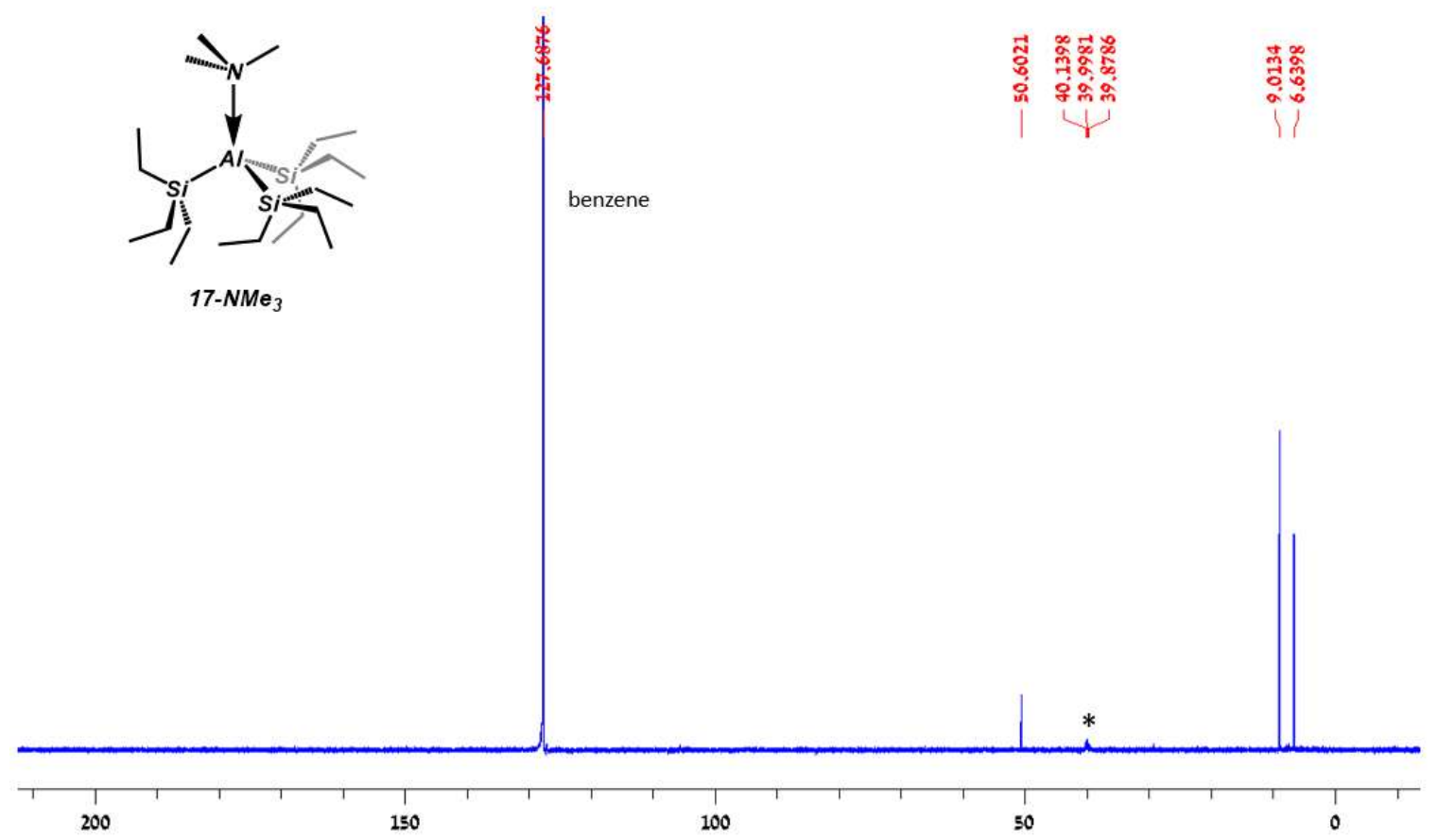

Figure S51. ${ }^{13} \mathrm{C}$ NMR of 17-NMe 3 in benzene (*: DMSO- $d_{6}$ capillary).

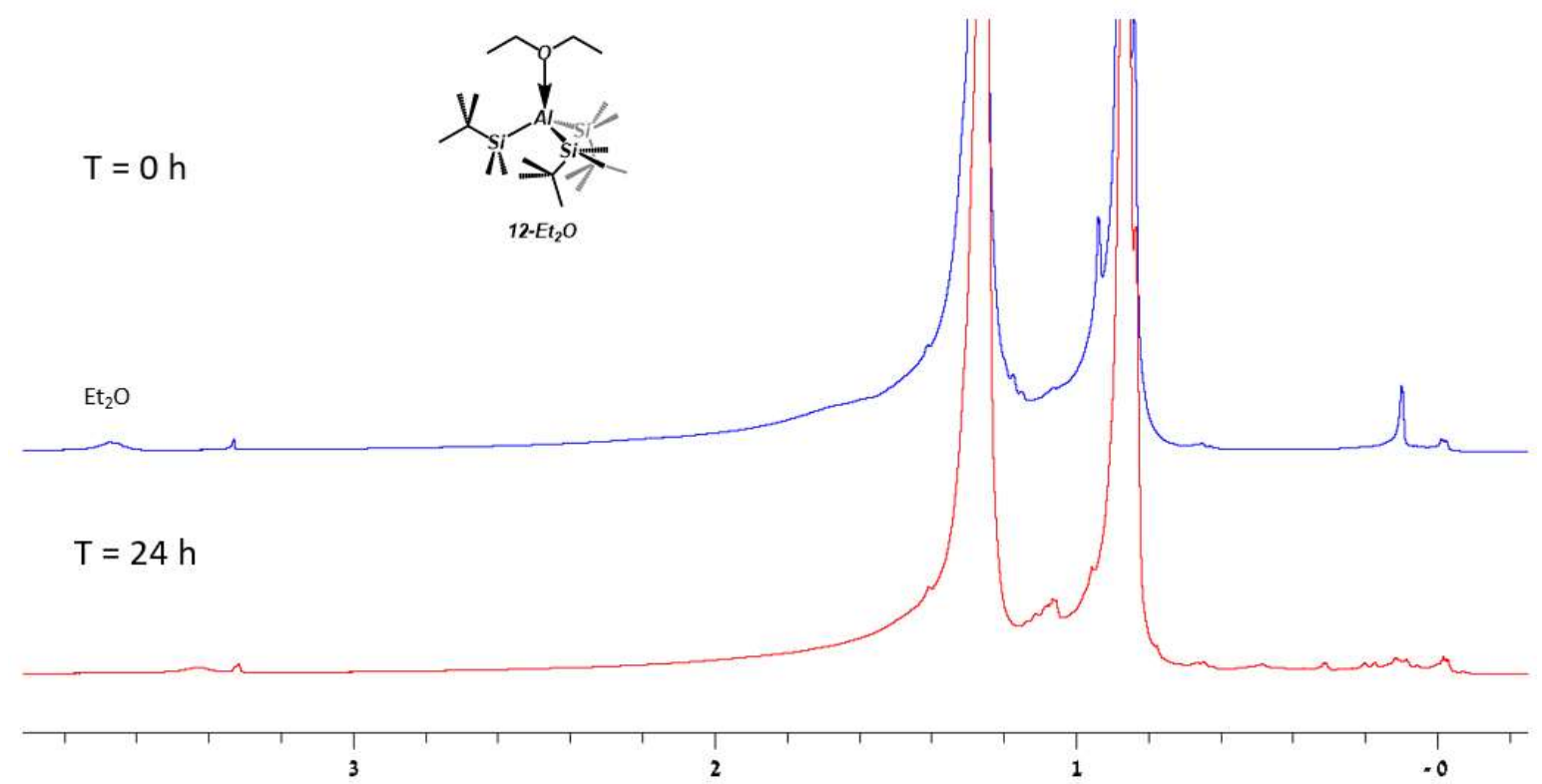

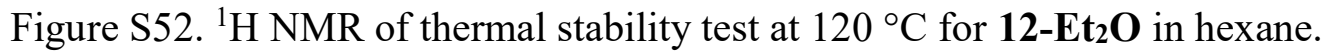




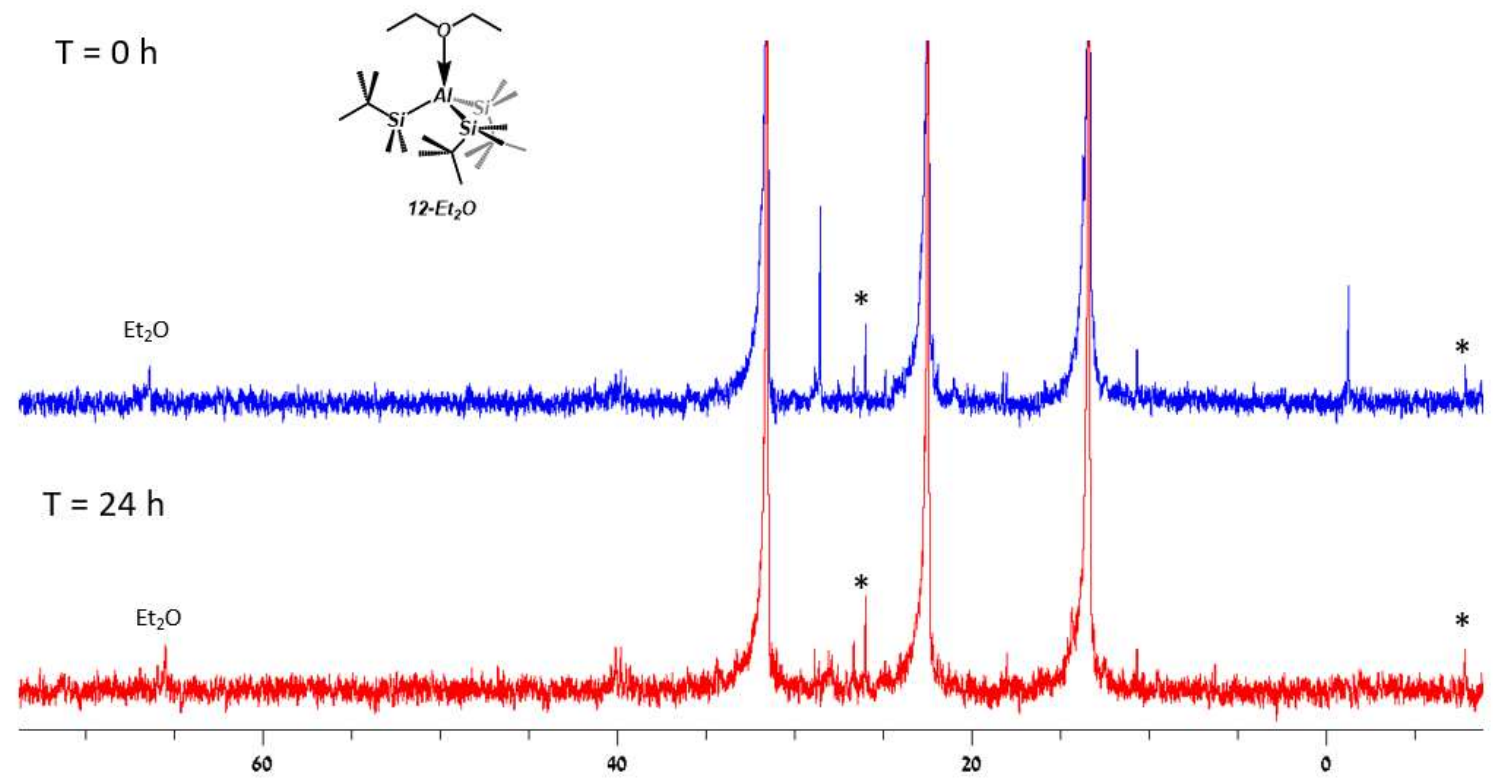

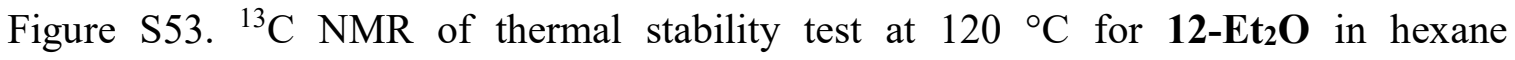
$\left(* \cdot{ }^{\mathrm{t}} \mathrm{BuMe} \mathrm{SiH}_{2} \mathrm{SiH}\right.$

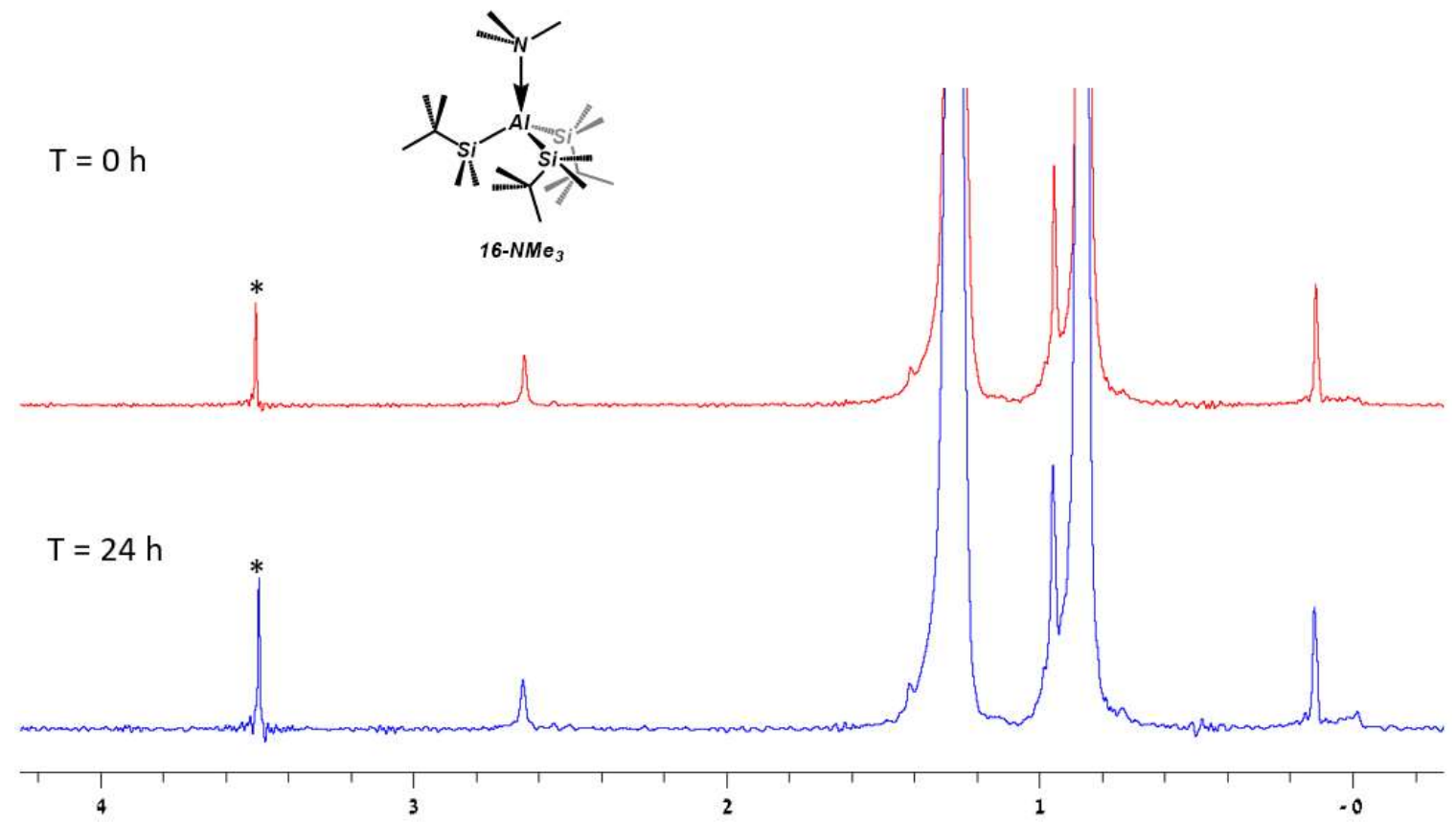

Figure S54. ${ }^{1} \mathrm{H}$ NMR of thermal stability test at $120{ }^{\circ} \mathrm{C}$ for $\mathbf{1 6}-\mathbf{N M e} 3$ in hexane $(*$ : traces of $\mathrm{H}_{2} \mathrm{O}$ in DMSO- $d_{6}$ capillary). 


$$
\mathrm{T}=\mathrm{O} \mathrm{h}
$$

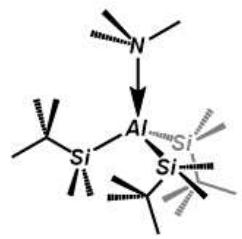

16-NMe 3

$\mathrm{T}=24 \mathrm{~h}$

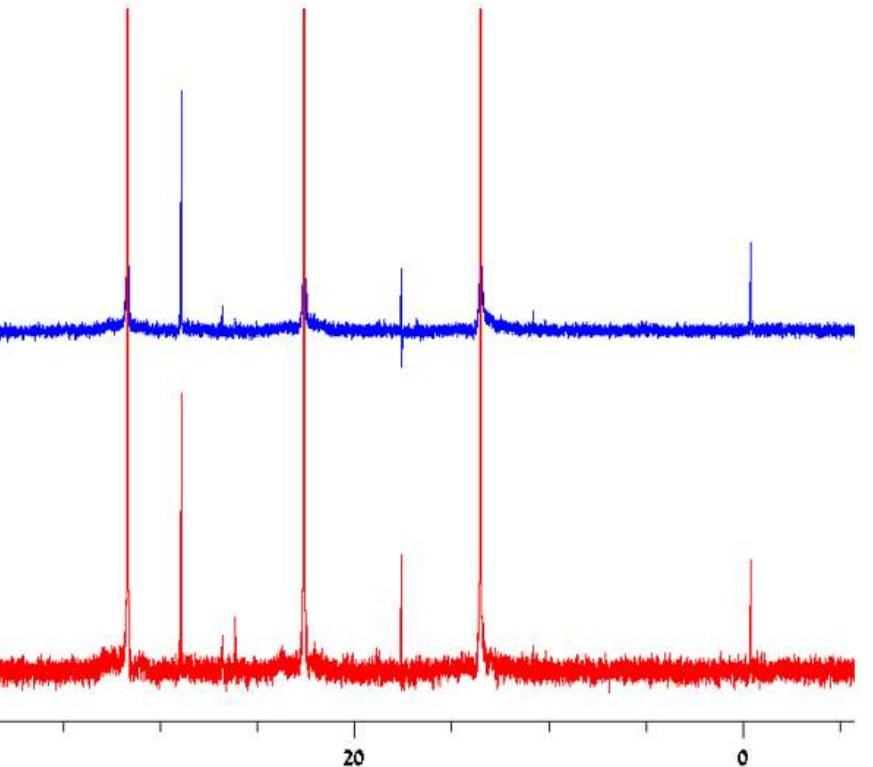

Figure S55. ${ }^{13} \mathrm{C}$ NMR of thermal stability test at $120{ }^{\circ} \mathrm{C}$ for $\mathbf{1 6}-\mathrm{NMe}_{3}$ in hexane.

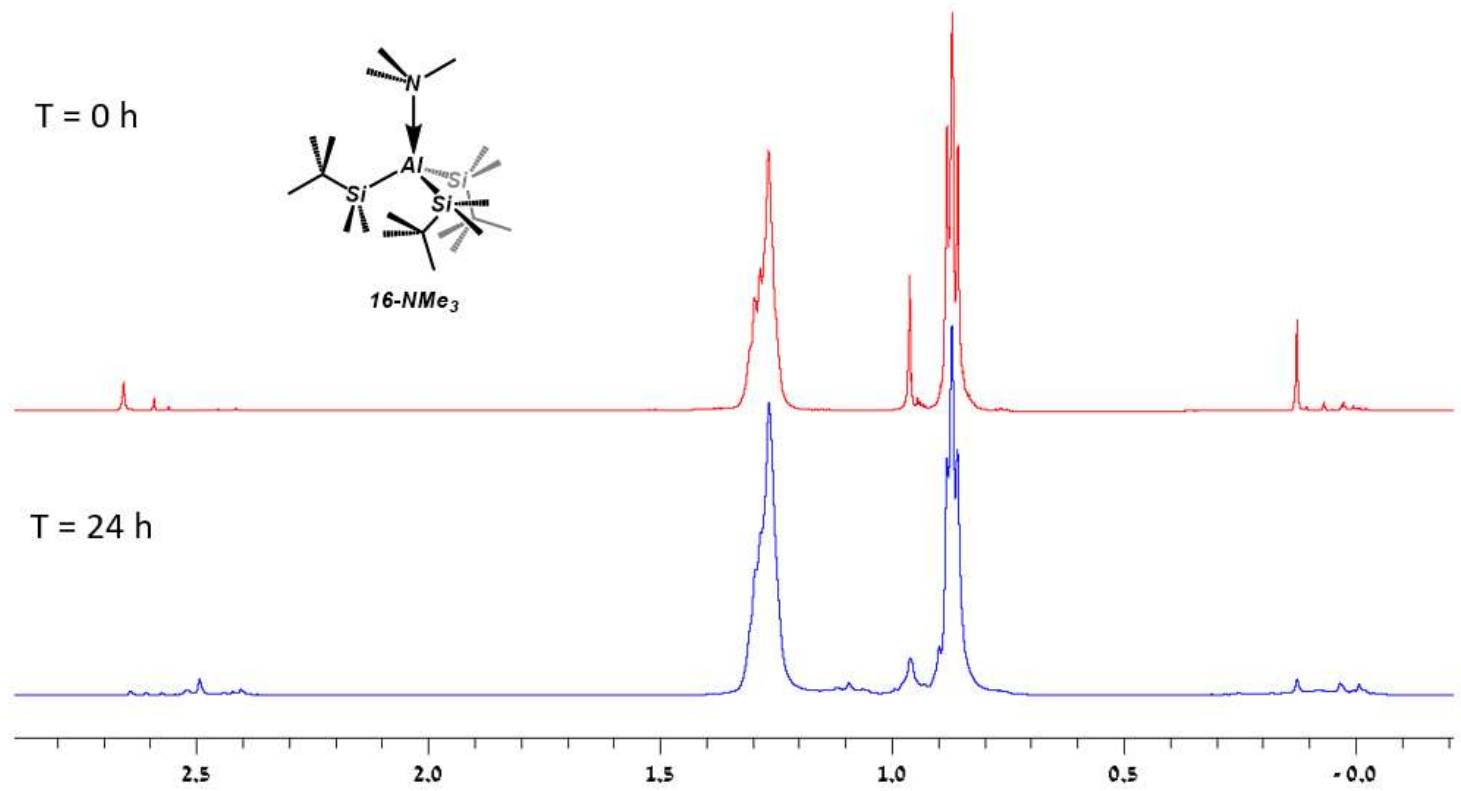

Figure S56. ${ }^{1} \mathrm{H}$ NMR of thermal stability test at $150{ }^{\circ} \mathrm{C}$ for $\mathbf{1 6 - N M e} 3$ in hexane. 


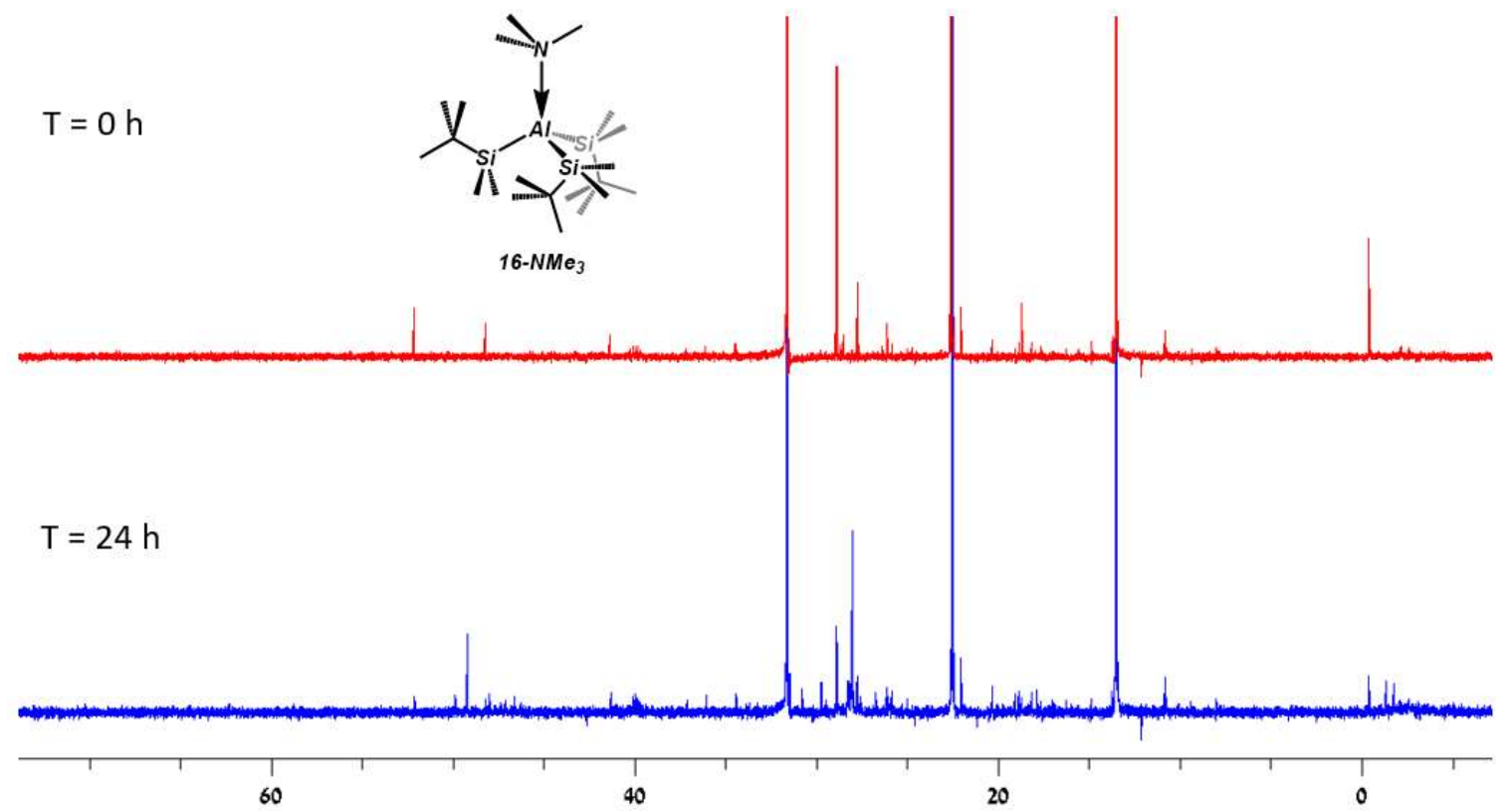

Figure S57. ${ }^{13} \mathrm{C}$ NMR of thermal stability test at $150{ }^{\circ} \mathrm{C}$ for $\mathbf{1 6}-\mathbf{N M e}_{3}$ in hexane.

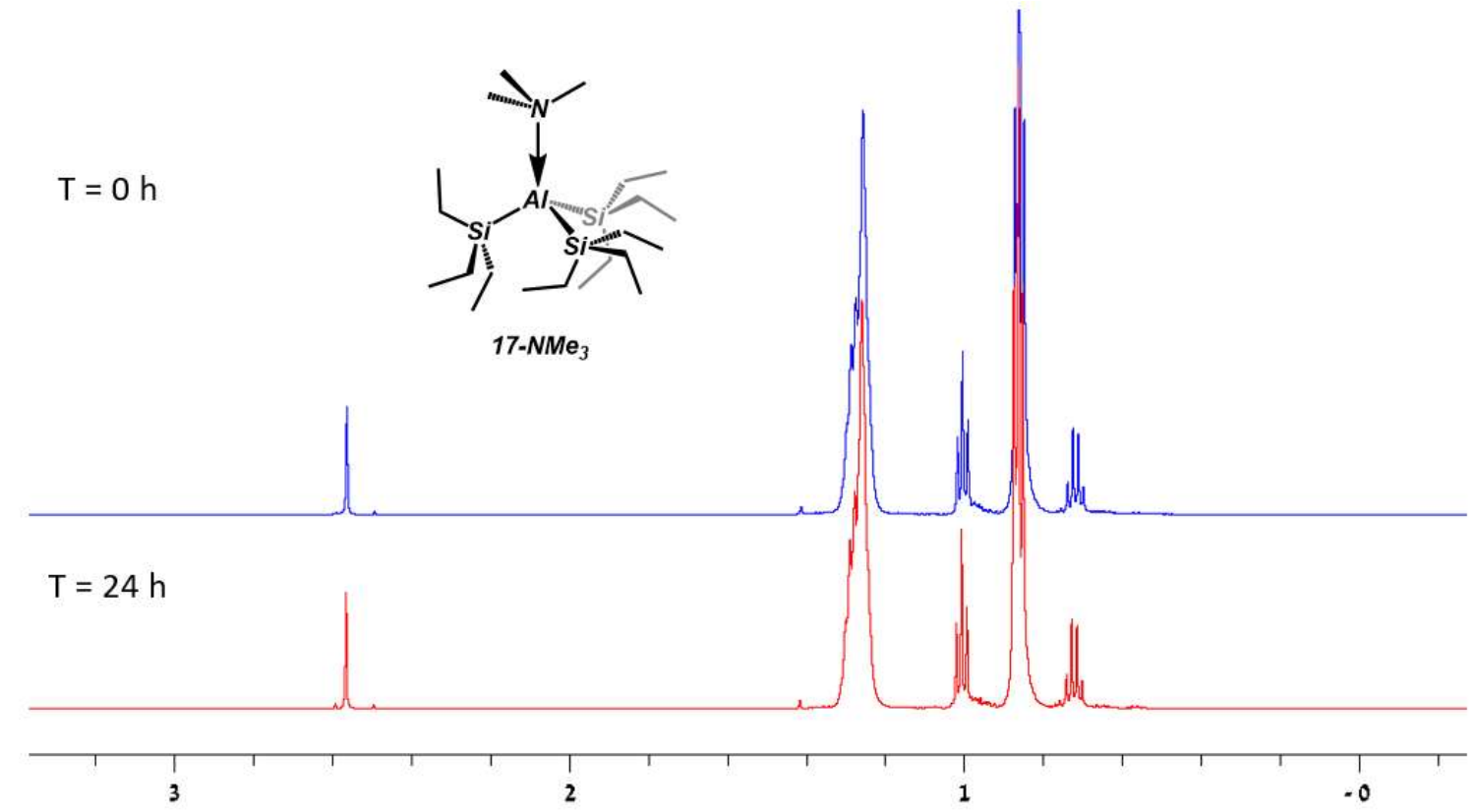

Figure S58. ${ }^{1} \mathrm{H}$ NMR of thermal stability test at $120^{\circ} \mathrm{C}$ for $\mathbf{1 7 - N M e} 3$ in hexane. 


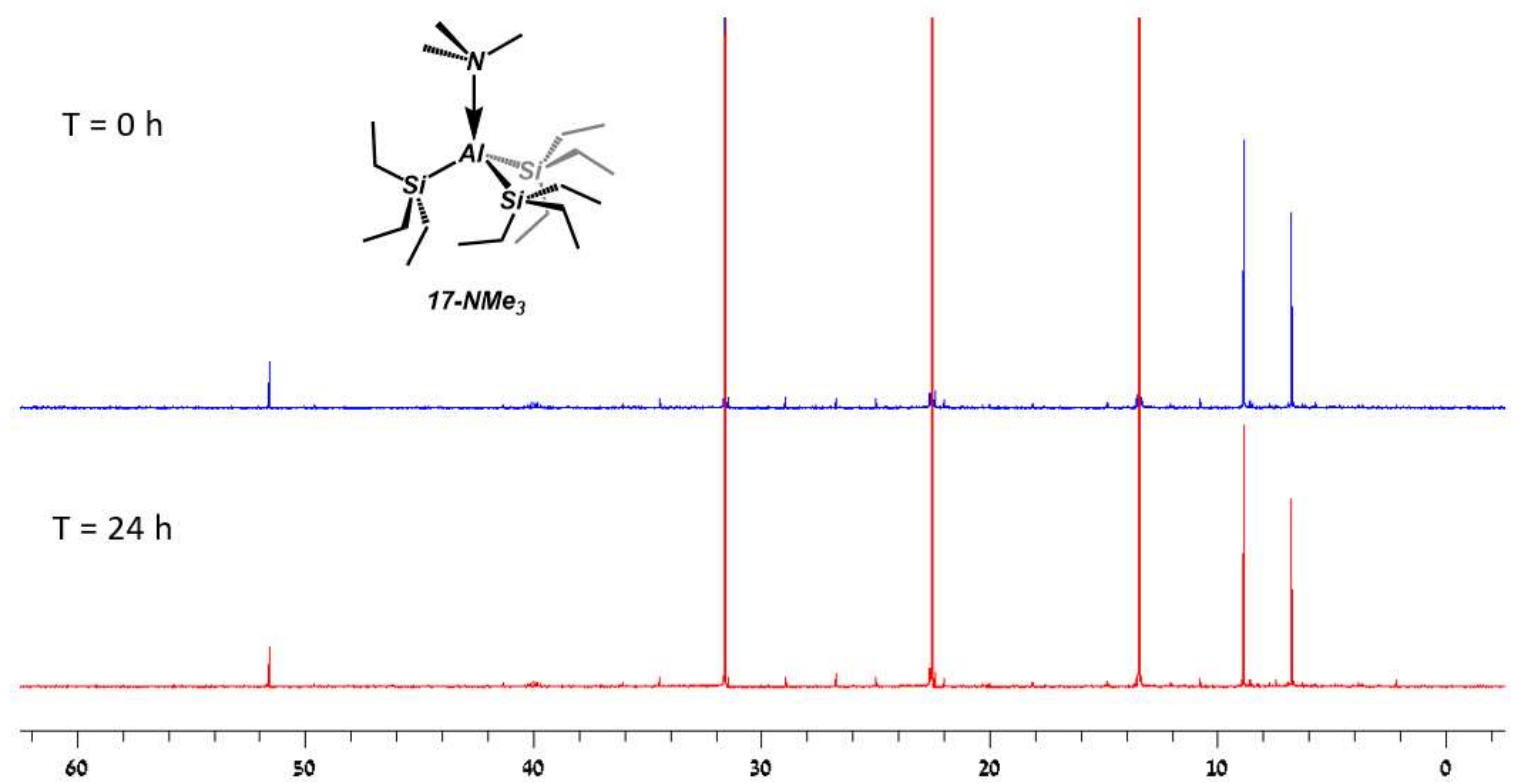

Figure S59. ${ }^{13} \mathrm{C}$ NMR of thermal stability test at $120{ }^{\circ} \mathrm{C}$ for $\mathbf{1 7 - N M e}$ in hexane.

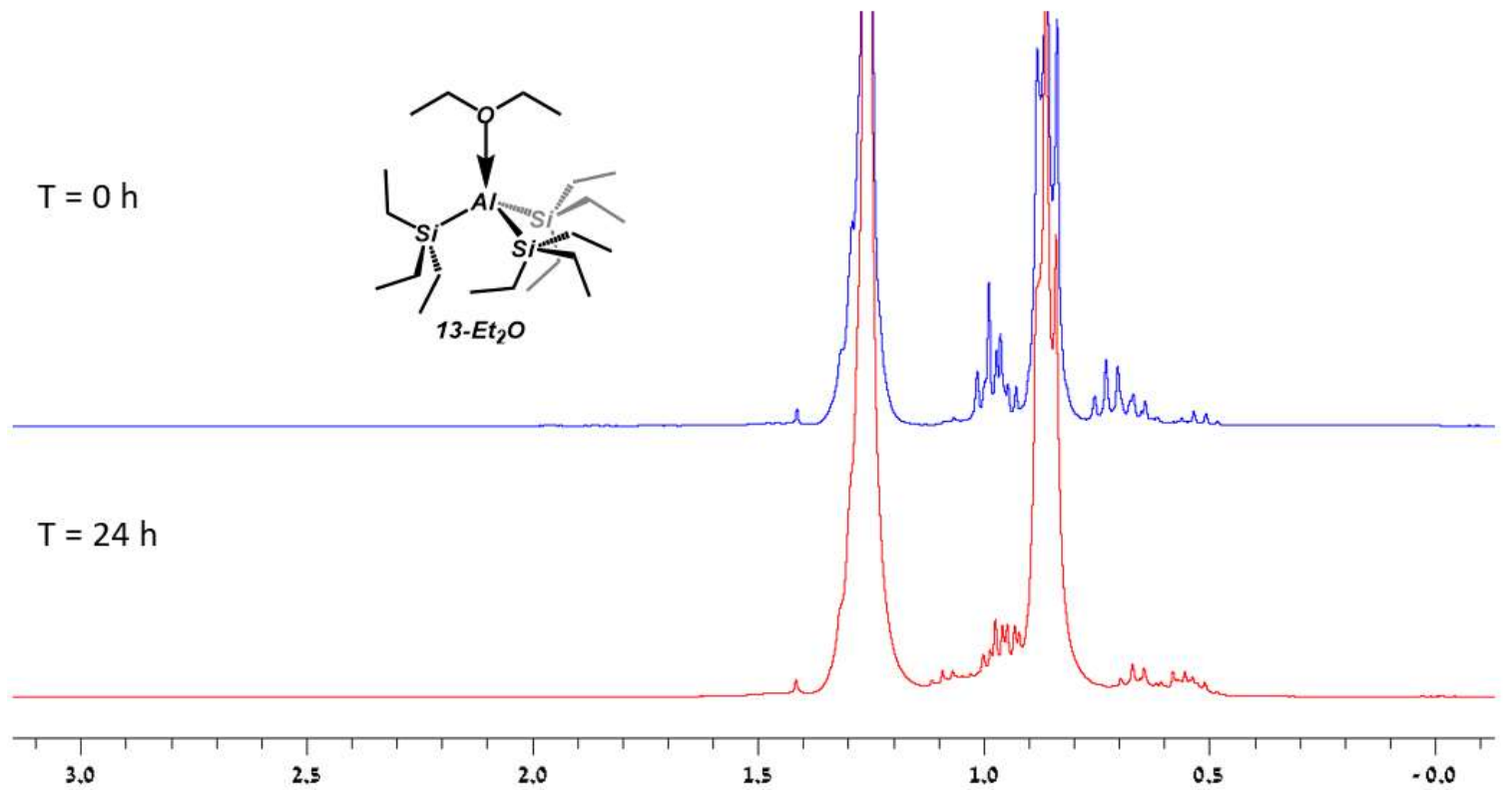

Figure S60. ${ }^{1} \mathrm{H}$ NMR of thermal stability test at $120^{\circ} \mathrm{C}$ for $\mathbf{1 3 - E t _ { 2 }} \mathbf{O}$ in hexane. 


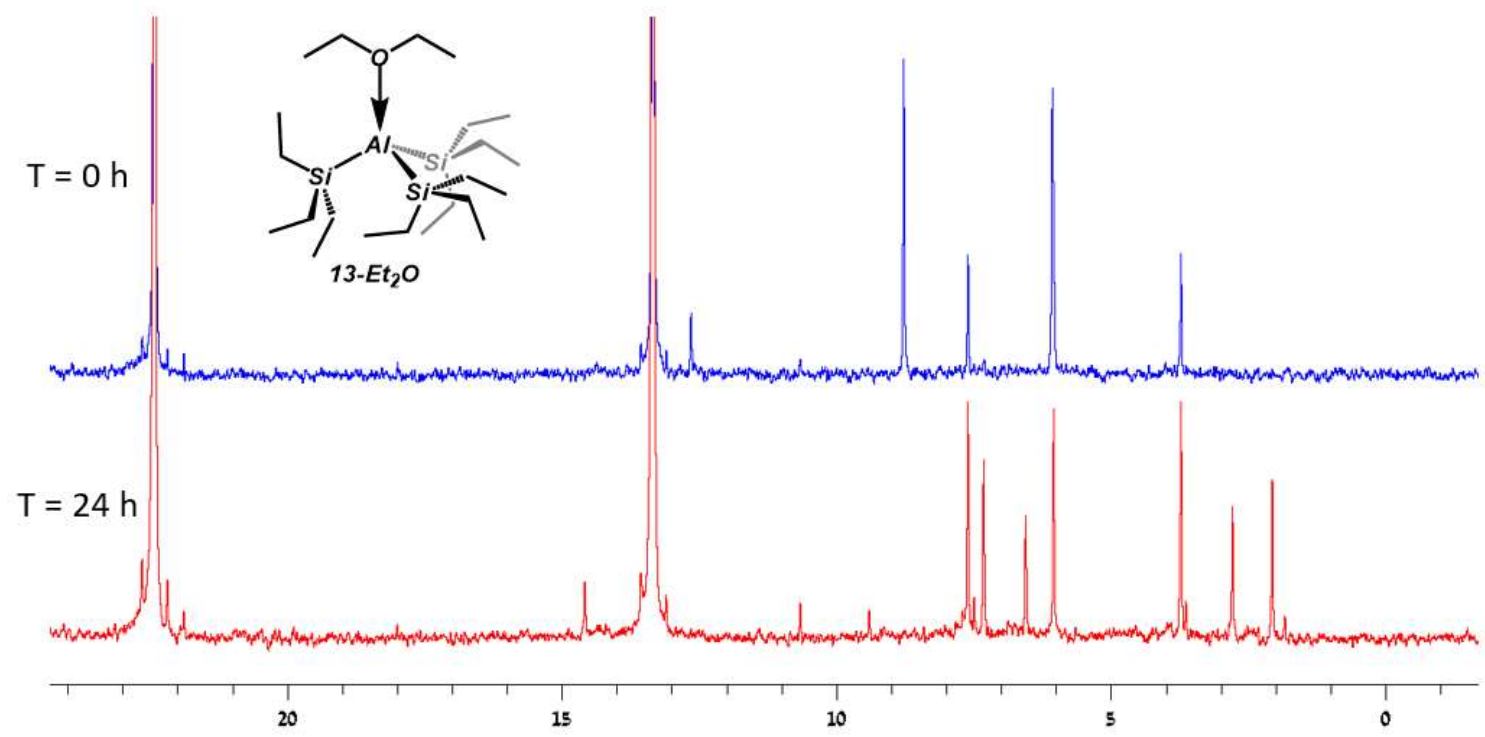

Figure S61. ${ }^{13} \mathrm{C}$ NMR of thermal stability test at $120{ }^{\circ} \mathrm{C}$ for $\mathbf{1 3 - E t _ { 2 }} \mathbf{O}$ in hexane.

\section{Thermal Analysis}

All thermal measurements were conducted in a glovebox under an $\operatorname{Ar}_{(\mathrm{g})}$ atmosphere. Thermogravimetric analysis (TGA) measurements were conducted with a TA Instrument Discovery TGA and all calorimetry measurements were conducted on a TA Instruments Discovery Differential Scanning Calorimeter (DSC). All TGA and DSC measurements were heated to $400{ }^{\circ} \mathrm{C}$ at a ramp rate of $5{ }^{\circ} \mathrm{C} / \mathrm{min}$. TGA samples were prepared using 5-8 mg's of sample in Aluminum $40 \mu \mathrm{L}$ crucibles. For DSC measurements samples were prepared with $5-8 \mathrm{mg}$ 's of material in Aluminum $40 \mu \mathrm{L}$ crucibles and then hermetically sealed with Al lids. All DSC measurements were referenced to an equivalent empty crucible/lid.

\section{Thermogravimetric Analysis Measurements:}




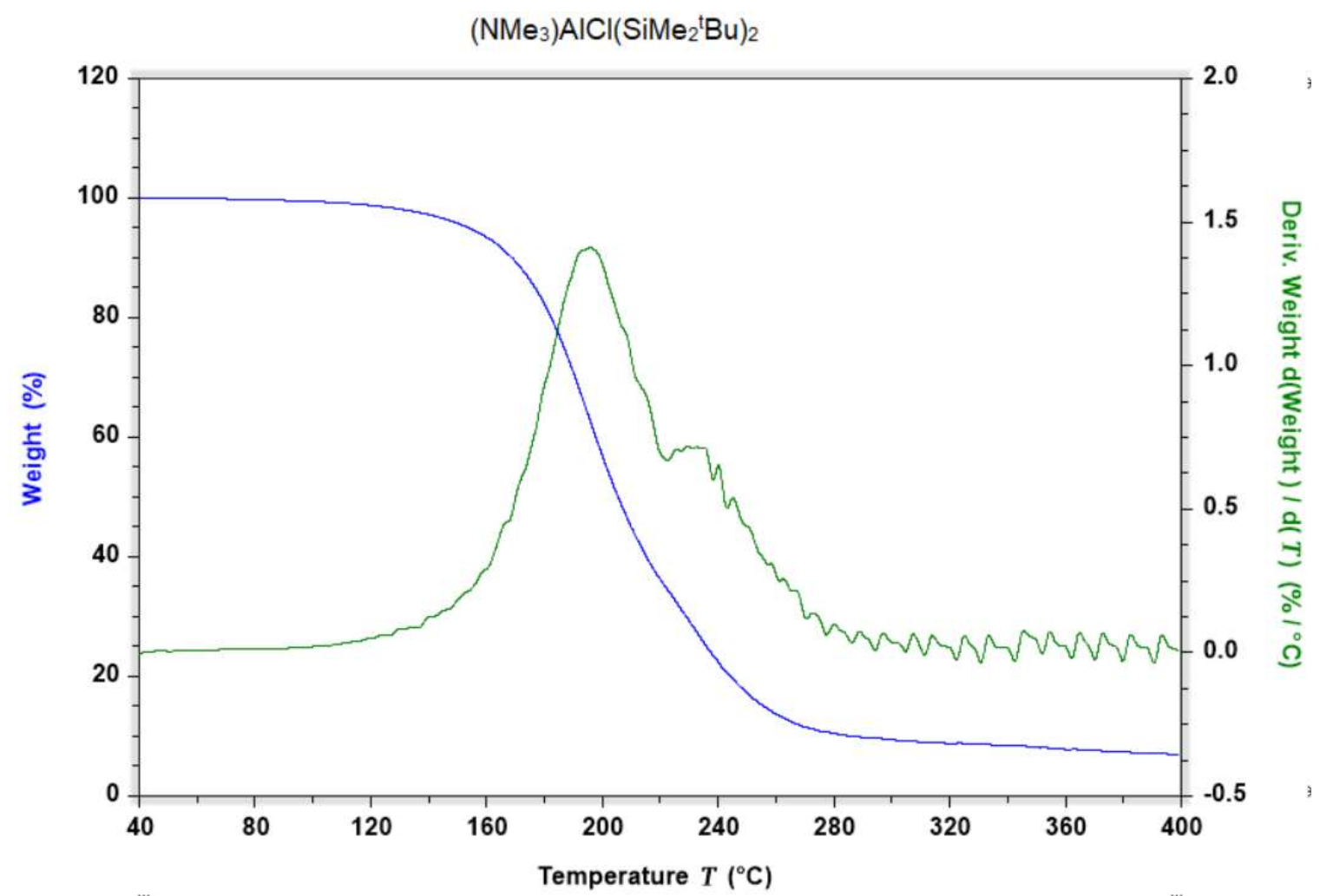

Figure S62. TGA analysis (blue) of complex 2-NMe3. Temperature ramp to $400{ }^{\circ} \mathrm{C}$ with a ramp rate of $5^{\circ} \mathrm{C} / \mathrm{min}$.

$\left(\mathrm{NMe}_{3}\right) \mathrm{AlBr}\left(\mathrm{SiMe}_{2}{ }^{\mathrm{t}} \mathrm{Bu}\right)_{2}$

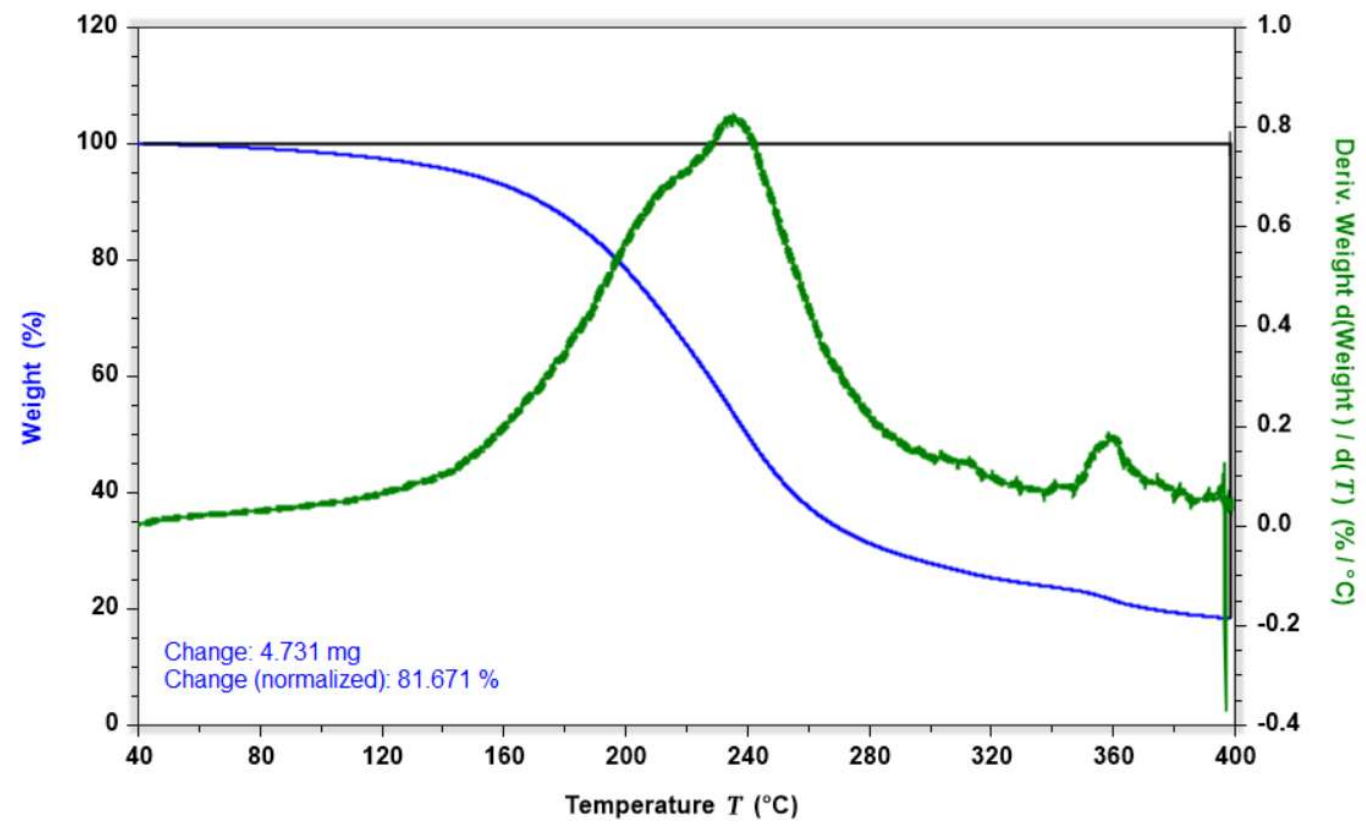

Figure S63. TGA analysis (blue) of complex 15-NMe3. Temperature ramp to $400{ }^{\circ} \mathrm{C}$ with a ramp rate of $5{ }^{\circ} \mathrm{C} / \mathrm{min}$. Black line indicates the region of the TGA trace that has been analyzed for mass loss. 


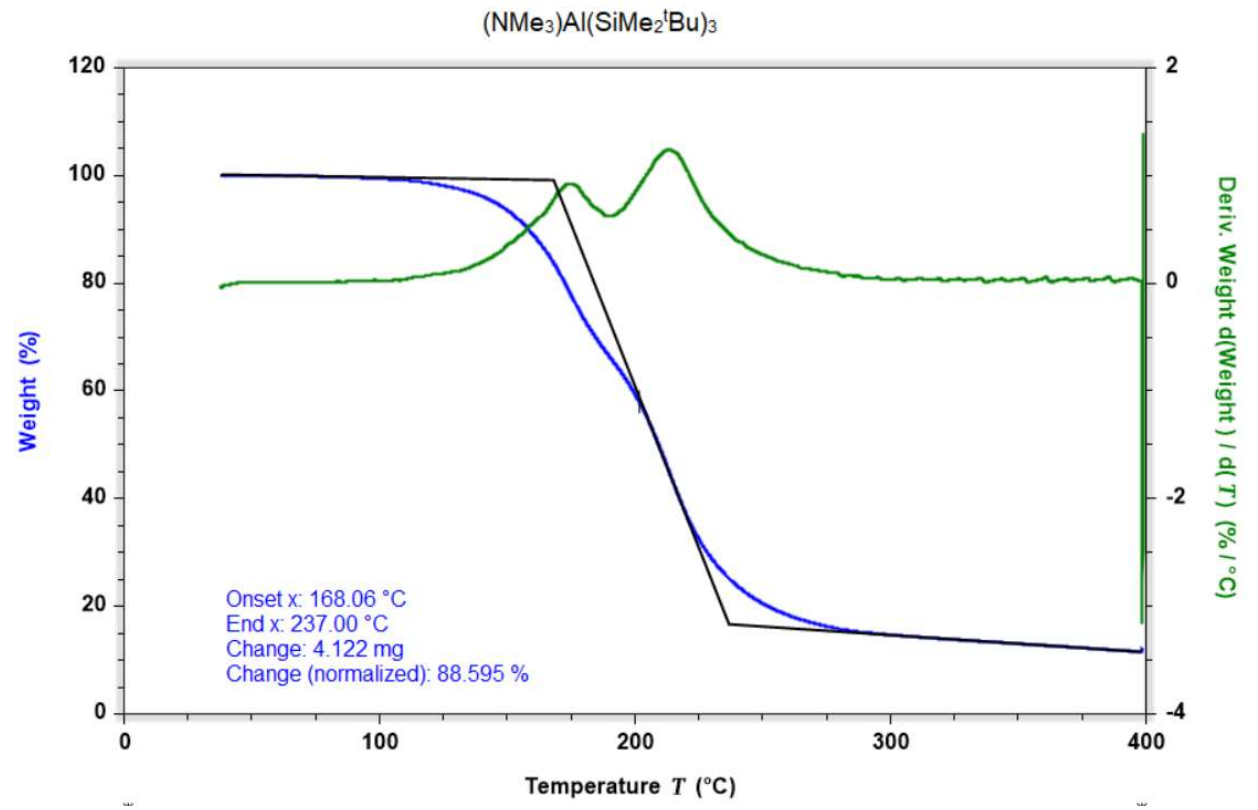

Figure S64. TGA analysis (blue) of complex 16-NMe3. Temperature ramp to $400{ }^{\circ} \mathrm{C}$ with a ramp rate of $5{ }^{\circ} \mathrm{C} / \mathrm{min}$. Black line indicates the region of the TGA trace that has been analyzed for mass loss.

\section{Differential Scanning Calorimetry Measurements:}

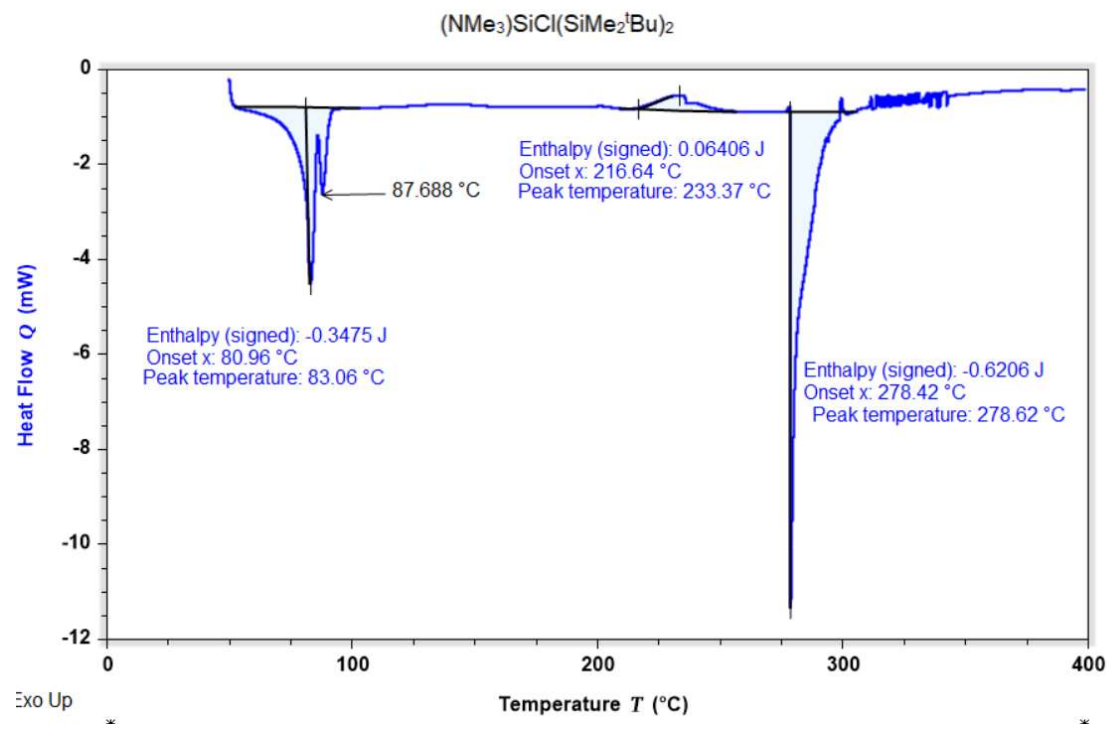

Figure S65. DSC analysis (blue) of complex 2-NMe3. Temperature ramp to $400{ }^{\circ} \mathrm{C}$ with a ramp rate of $5{ }^{\circ} \mathrm{C} / \mathrm{min}$. Black lines indicate regions of peak integration. 
$\left(\mathrm{NMe}_{3}\right) \mathrm{AIBr}\left(\mathrm{SiMe}_{2}{ }^{\mathrm{B}} \mathrm{Bu}\right)_{2}$

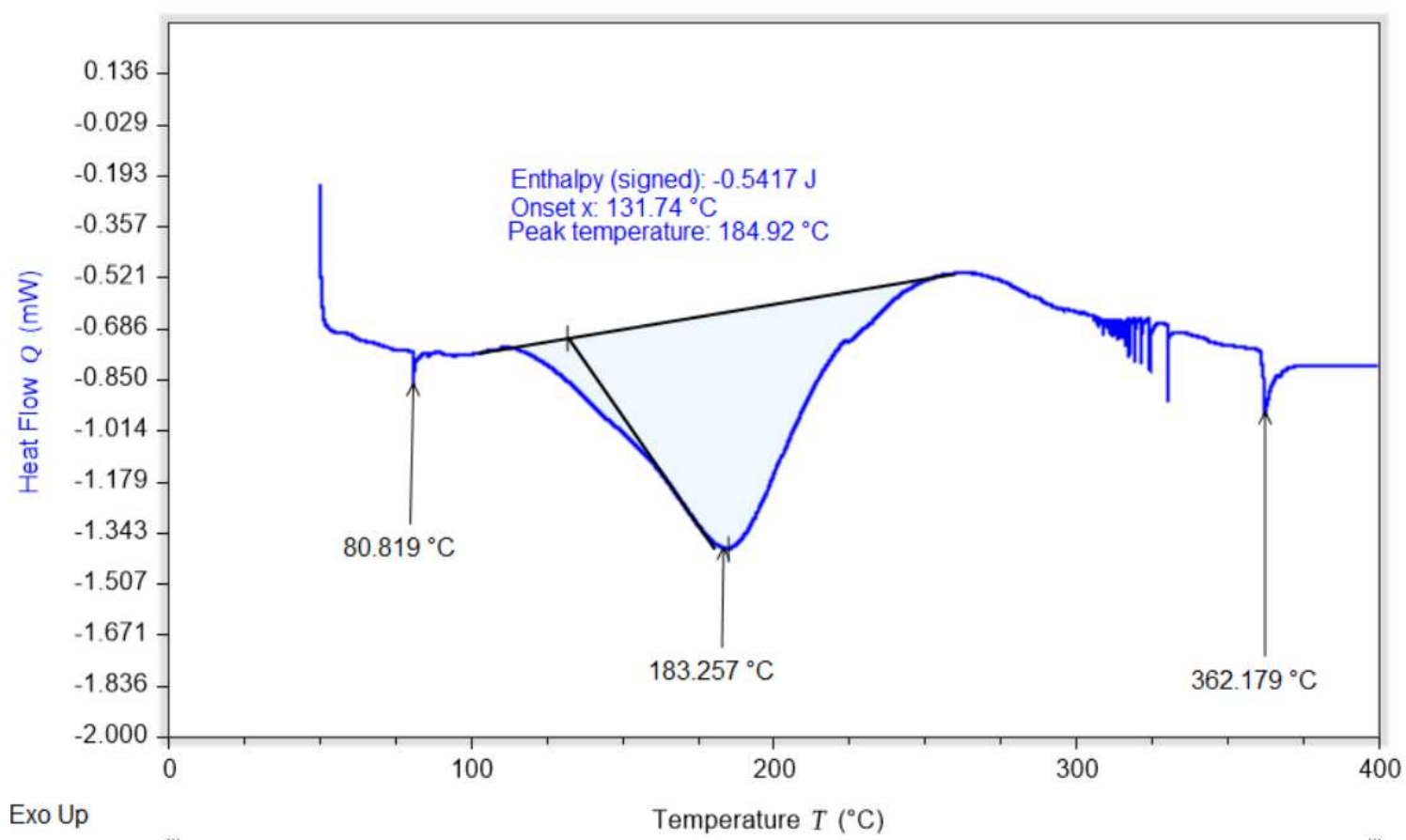

Figure S66. DSC analysis (blue) of complex 15-NMe3. Temperature ramp to $400{ }^{\circ} \mathrm{C}$ with a ramp rate of $5{ }^{\circ} \mathrm{C} / \mathrm{min}$. Black lines indicate regions of peak integration.

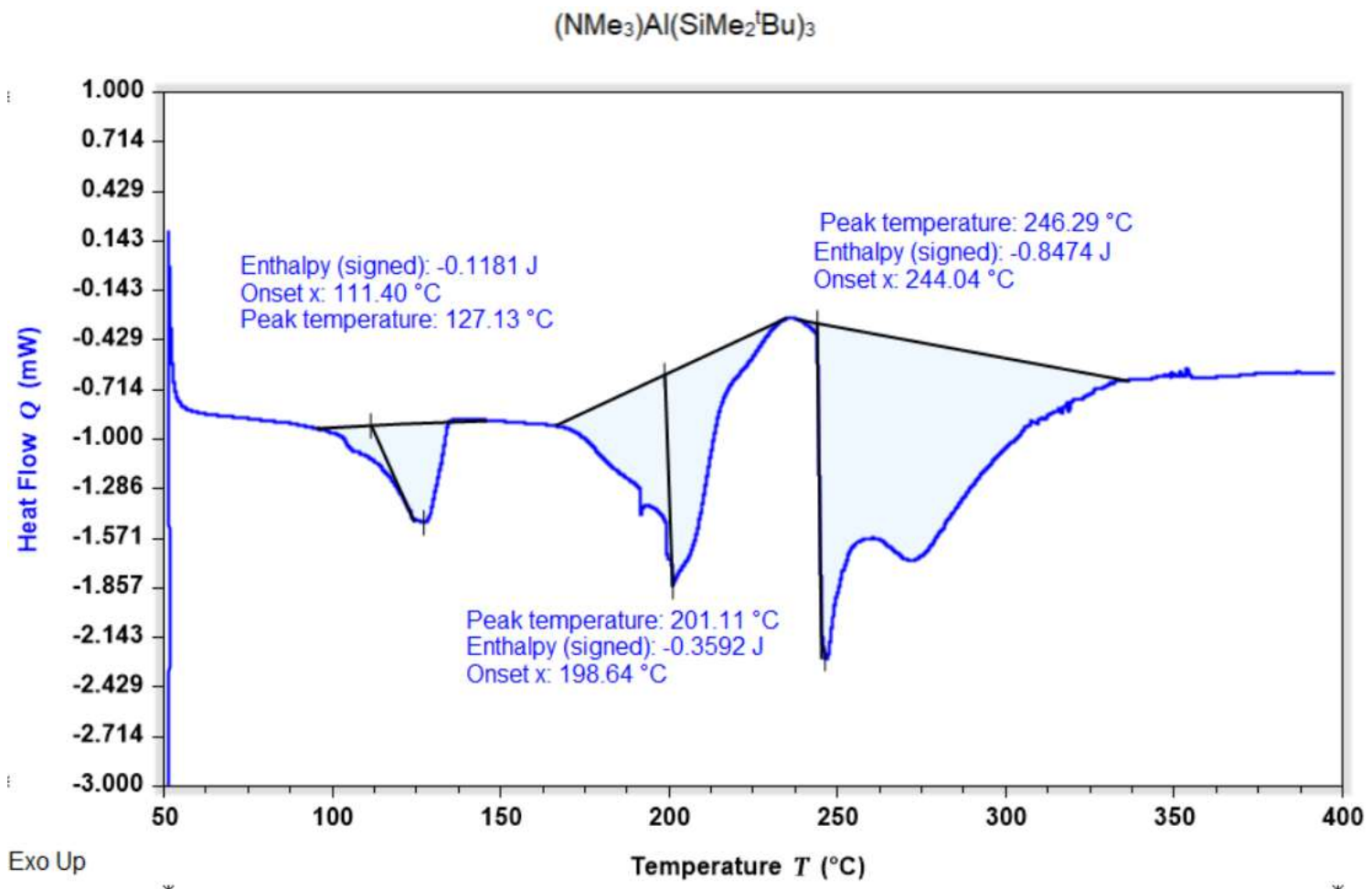

Figure S67. DSC analysis (blue) of complex 16-NMe3. Temperature ramp to $400{ }^{\circ} \mathrm{C}$ with a ramp rate of $5^{\circ} \mathrm{C} / \mathrm{min}$. Black lines indicate regions of peak integration. 


\section{Crystallographic Structure Determinations}

General Information: Single crystal X-ray structure determinations were carried out at low temperature $(200 \mathrm{~K})$ on a Bruker Kappa diffractometer equipped with a Mo Ka sealed tube radiation source, $\lambda=0.71073 \AA$, and a Bruker Apex-II detector using $\varphi$ and $\omega$ scans to cover the Ewald sphere. All structures were solved Charge Flipping and refined with the ShelXL ${ }^{12}$ refinement package using Least Squares minimization in the Olex ${ }^{13}$ smallmolecule solution, refinement and analysis software package. ${ }^{14}$ Samples of complexes 2$\mathrm{NMe}_{2}, 3, \mathbf{3}-\mathrm{Br}, 10,11,12-\mathbf{E t}_{2} \mathrm{O}$ and 14- $\mathbf{L i}\left(\mathbf{E t}_{2} \mathrm{O}\right)_{2}$ were analyzed. The typical crystal habits were colorless plates which were immersed and mounted in Paratone-N oil for collection.

All non-hydrogen atoms were refined with anisotropic displacement parameters. The hydrogen atoms were refined isotopically on calculated positions using a riding model with their $U_{\text {iso }}$ values constrained to 1.5 times the $U_{\text {eq }}$ of their pivot atoms for terminal $\mathrm{sp}^{3}$ carbon atoms and 1.2 times for all other carbon atoms. Software used for molecular graphics: Mercury 3.10.1. ${ }^{15}$ The crystallographic details for complexes 2-NMe3 (CCDC 1980114), 3 (CCDC 2014345), 5-Br (CCDC 1980112), 10 (CCDC 1980115), 11 (CCDC 1980300), 12-Et 2 O (CCDC 1980116) and 14-Li(Et2O)2 (CCDC 1980113), have been deposited into the Cambridge Structural Database.

Information on Crystallographic Disorder: The following molecules contain positionally disordered components that were modeled and refined anisotropically. They are listed along with their respective disordered components.

Complex 10: Three disordered Si atoms in ${ }^{\mathrm{t}} \mathrm{BuMe}{ }_{2} \mathrm{Si}$ groups were modeled. Sil and Si1A are disordered over two sites with occupancies 0.8:0.2; $\mathrm{Si} 2$ and $\mathrm{Si} 2 \mathrm{~A}$ are disordered over two sites with occupancies $0.75: 0.25$; $\mathrm{Si} 3$ and $\mathrm{Si3A}$ are disordered over two sites with occupancies 0.75:0.25.

Complex 14-Li(Et $\left.\mathbf{E}_{2} \mathrm{O}\right)_{2}$ : Two disordered $\mathrm{Et}_{2} \mathrm{O}$ solvent molecules were modeled. $\mathrm{O} 2$ and O2A are disordered over two sites with occupancies 0.829:0.171; C27, C28 and C27A, C28A are disordered over two sites with occupancies 0.5:0.5. 


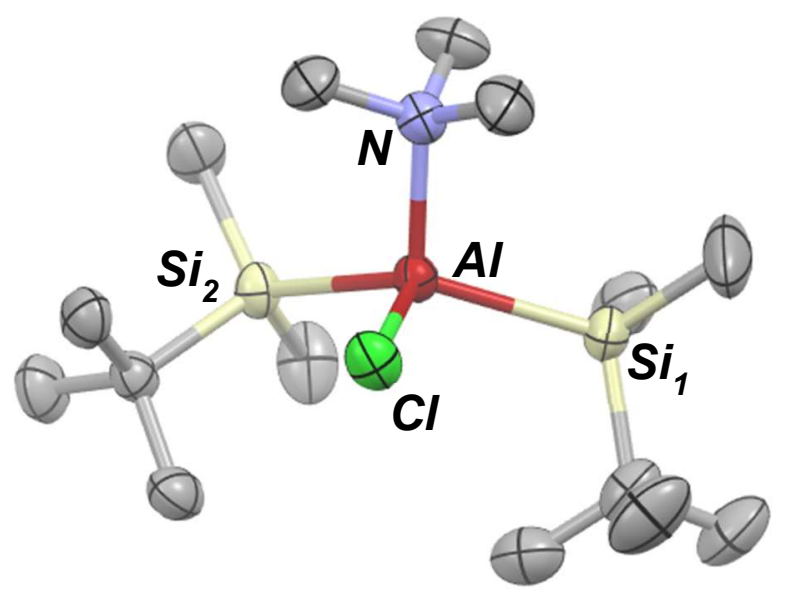

Figure S68. Solid state molecular structure of complex 2-NMe3. Hydrogen atoms omitted for clarity. Selected bond lengths $(\AA)$ : $\mathrm{Cl}-\mathrm{Al}=2.199(10), \mathrm{Si}_{1}-\mathrm{Al}=2.491(11), \mathrm{Si}_{2}-\mathrm{Al}=$ 2.507(10), Al-N $=2.031(2)$. Selected bond angles $\left({ }^{\circ}\right): \mathrm{N}-\mathrm{Al}-\mathrm{Cl}=97.8(7), \mathrm{N}-\mathrm{Al}-\mathrm{Si}_{1}=$ 108.8(7), Cl-Al-Si $i_{1}=110.4(4), \mathrm{N}-\mathrm{Al}-\mathrm{Si}_{2}=107.6(7), \mathrm{Cl}-\mathrm{Al}-\mathrm{Si}_{2}=111.5(4), \mathrm{Si}_{1}-\mathrm{Al}-\mathrm{Si}_{2}=$ 118.3(4), $\mathrm{Si}_{1}-\mathrm{Al}-\mathrm{Si}_{2}-\mathrm{Cl}=129.7(0), \mathrm{Si}_{1}-\mathrm{Al}-\mathrm{N}-\mathrm{Cl}=115.6(0)$.

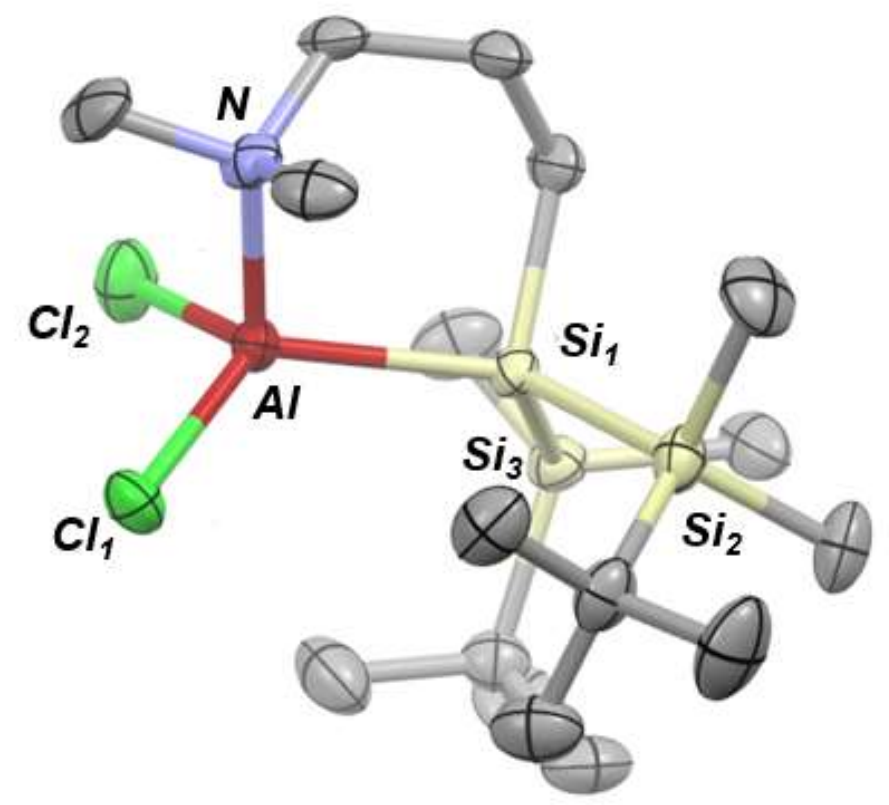

Figure S69. Solid state molecular structure of complex 3. Hydrogen atoms omitted for clarity. Selected bond lengths $(\AA)$ : Al-N $=1.989(3), \mathrm{Si}_{1}-\mathrm{Al}=2.413(12), \mathrm{Si}_{1}-\mathrm{Si}_{2}=$ 2.375(12), Al-Cl $=2.140(13), \mathrm{Al}_{1} \mathrm{Cl}_{2}=2.1607(12)$. Selected bond angles $\left({ }^{\circ}\right)$ : $\mathrm{N}-\mathrm{Al}_{-}-\mathrm{Cl}_{1}=$ 105.4(9), N-Al-Si $i_{1}=103.89(8), \mathrm{Si}_{2}-\mathrm{Si}_{1}-\mathrm{Si}_{3}=112.1(4), \mathrm{Si}_{2}-\mathrm{Si}_{1}-\mathrm{Al}=121.8(5), \mathrm{Si}_{3}-\mathrm{Si}_{1}-\mathrm{Al}=$ 106.5(5); $\mathrm{Si}_{1}-\mathrm{Al}-\mathrm{N}-\mathrm{Cl}=118.8(0), \mathrm{Si}_{2}-\mathrm{Si}_{1}-\mathrm{Si}_{3}-\mathrm{Al}=135.5(0), \mathrm{Si}_{2}-\mathrm{Si}_{1}-\mathrm{Al}-\mathrm{N}=73.2(0)$. 


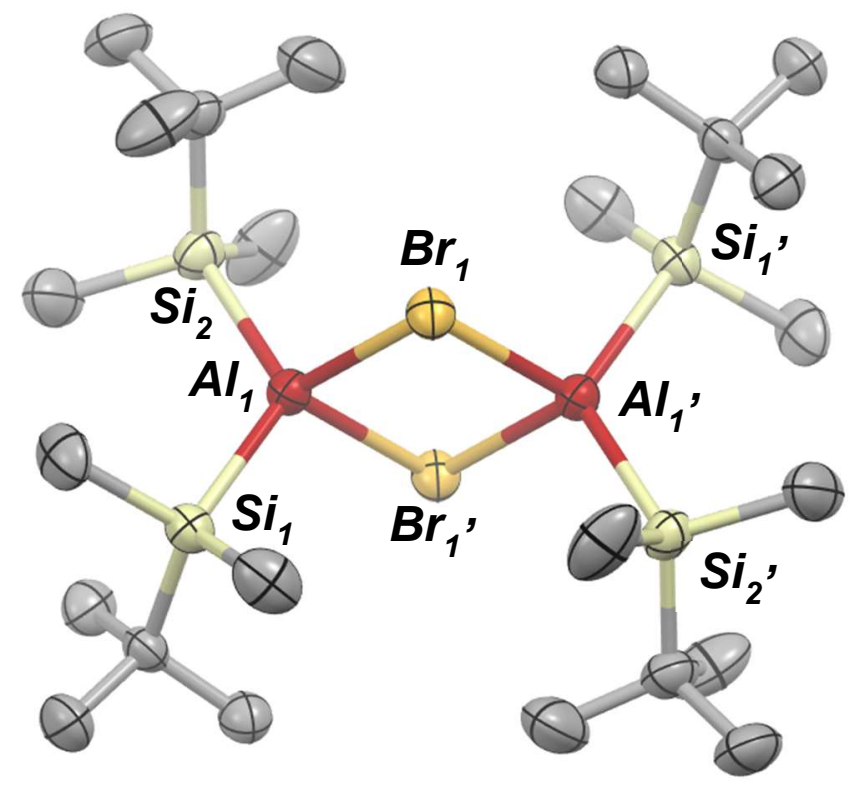

Figure S70. Solid state molecular structure of complex 5-Br. Hydrogen atoms omitted for clarity. Selected bond lengths $(\AA): \mathrm{Si}_{1}-\mathrm{Al}_{1}=2.468(19), \mathrm{Si}_{2}-\mathrm{Al}_{1}=2.462(17), \mathrm{Br}_{1}-\mathrm{Al}_{1}=$ 2.497(13), $\mathrm{Br}_{1}-\mathrm{Al}_{1}{ }^{\prime}=2.508(12), \mathrm{Al}_{1}-\mathrm{Br}_{1}{ }^{\prime}=2.508(12), \mathrm{Al}_{1}-\mathrm{Al}_{1}{ }^{\prime}=3.550(0)$. Selected bond angles $\left({ }^{\circ}\right): \mathrm{Si}_{2}-\mathrm{Al}_{1}-\mathrm{Si}_{1}=123.6(7), \mathrm{Si}_{2}-\mathrm{Al}_{1}-\mathrm{Br}_{1}=112.0(6), \mathrm{Si}_{1}-\mathrm{Al}_{1}-\mathrm{Br}_{1}=106.7(6), \mathrm{Si}_{2}-\mathrm{Al}_{1}-$ $\mathrm{Br}_{1}{ }^{\prime}=106.3(5), \mathrm{Si}_{1}-\mathrm{Al}_{1}-\mathrm{Br}_{1}{ }^{\prime}=113.3(6), \mathrm{Al}_{1}-\mathrm{Br}_{1}-\mathrm{Al}_{1}{ }^{\prime}=90.3(4), \mathrm{Br}_{1}-\mathrm{Al}_{1}-\mathrm{Br}_{1}{ }^{\prime}=89.6(6)$, $\mathrm{Si}_{1}-\mathrm{Al}_{1}-\mathrm{Al}_{1}{ }^{\prime}-\mathrm{Si}_{2}{ }^{\prime}=0.5(0), \mathrm{Si}_{1}-\mathrm{Al}_{1}-\mathrm{Br}_{1}-\mathrm{Al}_{1}{ }^{`}=114.2(0), \mathrm{Al}_{1}-\mathrm{Br}_{1}-\mathrm{Al}_{1}{ }^{\prime}-\mathrm{Br}_{1}{ }^{`} 0.0(0)$.

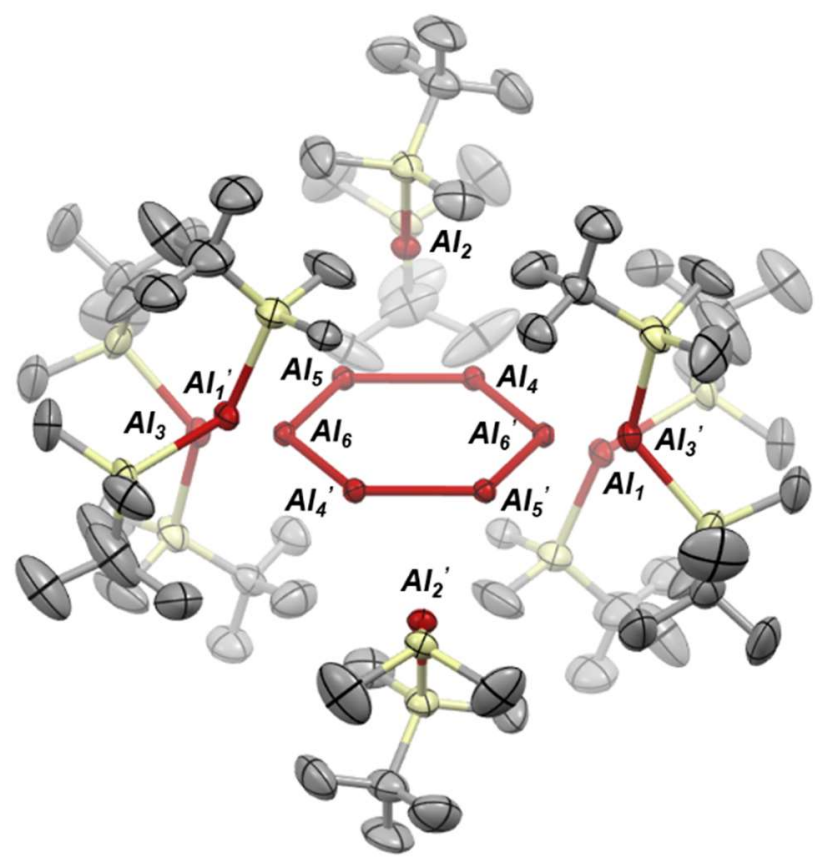

Figure S71. Solid state molecular structure of complex 10. Hydrogen atoms omitted for clarity. 


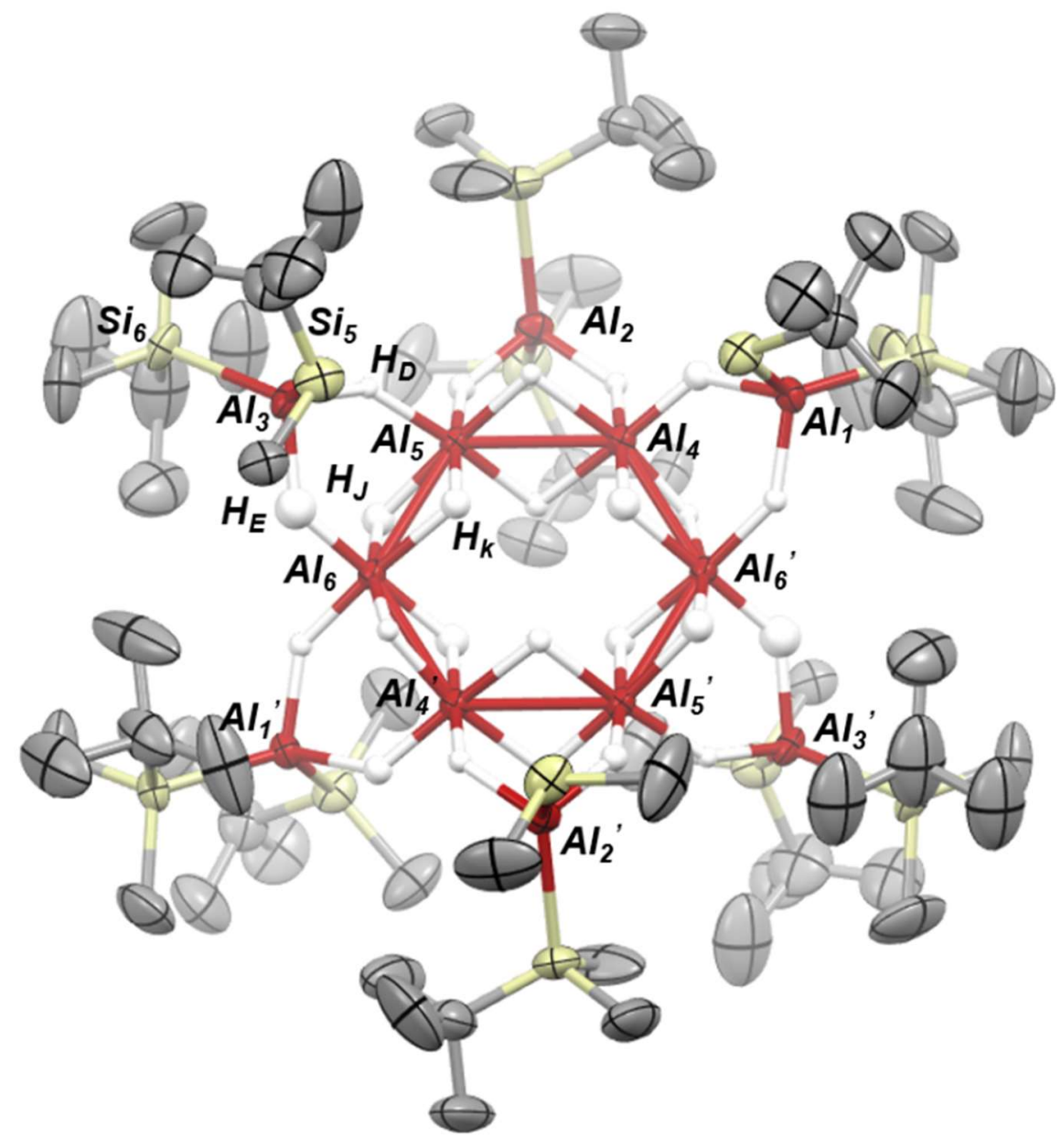

Figure S72. Solid state molecular structure of complex 10 with bridging hydrides. Peripheral Hydrogen atoms and Si-R groups omitted for clarity. Selected bond lengths $(\AA)$ : $\mathrm{Si}_{5}-\mathrm{Al}_{3}=2.456(3), \mathrm{Si}_{6}-\mathrm{Al}_{3}=2.448(2), \mathrm{Al}_{4}-\mathrm{Al}_{5}=2.599(2), \mathrm{Al}_{4}-\mathrm{Al}_{6}{ }^{\prime}=2.606(2), \mathrm{Al}_{5}-\mathrm{Al}_{6}=$ 2.613(2), $\mathrm{Al}_{2}-\mathrm{Al}_{4}=3.146(0), \mathrm{Al}_{2}-\mathrm{Al}_{5}=3.150(0), \mathrm{Al}_{3}-\mathrm{H}_{\mathrm{D}}=1.670(4), \mathrm{Al}_{3}-\mathrm{H}_{\mathrm{J}}=1.620(4)$, $\mathrm{Al}_{5}-\mathrm{H}_{\mathrm{D}}=1.830(4), \mathrm{Al}_{6}-\mathrm{H}_{\mathrm{E}}=1.770(4), \mathrm{Al}_{5}-\mathrm{H}_{\mathrm{K}}=1.820(4), \mathrm{Al}_{6}-\mathrm{H}_{\mathrm{K}}=1.770(4), \mathrm{Al}_{5}-\mathrm{H}_{\mathrm{J}}=$ $1.890(4), \mathrm{Al}_{6}-\mathrm{H}_{\mathrm{J}}=1.730(4)$. Selected bond angles $\left({ }^{\circ}\right): \mathrm{Si}_{6}-\mathrm{Al}_{3}-\mathrm{Si}_{5}=123.9(10), \mathrm{Al}_{5}-\mathrm{Al}_{4}-$ $\mathrm{Al}_{6}{ }^{\prime}=120.0(7), \mathrm{Al}_{4}-\mathrm{Al}_{5}-\mathrm{Al}_{6}=119.2(8), \mathrm{Al}_{4}{ }^{\prime}-\mathrm{Al}_{6}-\mathrm{Al}_{5}=120.72(7), \mathrm{H}_{\mathrm{E}}-\mathrm{Al}_{3}-\mathrm{H}_{\mathrm{D}}=94.6(0)$, $\mathrm{Al}_{3}-\mathrm{H}_{\mathrm{D}}-\mathrm{Al}_{5}=127.4(0), \mathrm{Al}_{5}-\mathrm{H}_{\mathrm{J}}-\mathrm{Al}_{6}=92.0(0), \mathrm{Al}_{4}-\mathrm{Al}_{5}-\mathrm{Al}_{6}-\mathrm{Al}_{4}{ }^{\prime}=0.7(0), \mathrm{Al}_{5}-\mathrm{H}_{\mathrm{J}}-\mathrm{Al}_{6}-\mathrm{H}_{\mathrm{K}}=$ 2.1(0), $\mathrm{Al}_{5}-\mathrm{H}_{\mathrm{D}}-\mathrm{Al}_{3}-\mathrm{H}_{\mathrm{E}}=32.3(0)$. 

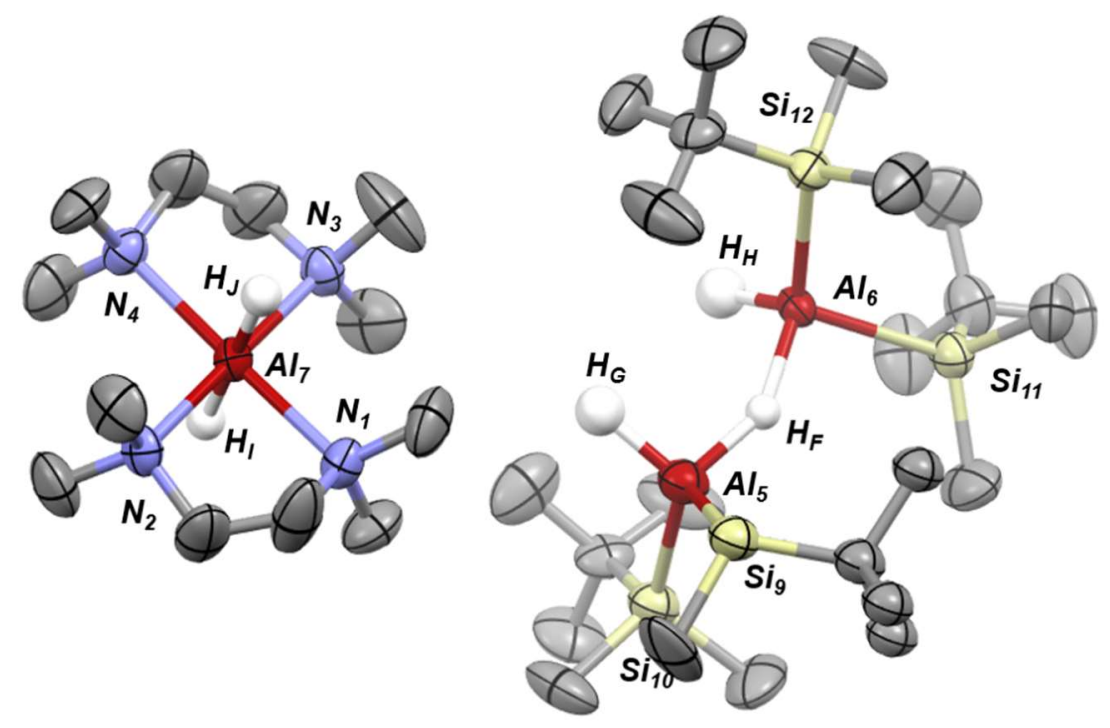

Figure S73. Solid state molecular structure of complex 11. Hydrogen atoms omitted for clarity. Selected bond lengths $(\AA): \mathrm{Al}_{5}-\mathrm{Al}_{6}=3.245(0), \mathrm{Al}_{5}-\mathrm{H}_{\mathrm{F}}=1.576(0), \mathrm{Al}_{6}-\mathrm{H}_{\mathrm{F}}=$ 1.790(0), $\mathrm{Si}_{9}-\mathrm{Al}_{5}=2.483(3), \mathrm{Si}_{10}-\mathrm{Al}_{5}=2.479(3), \mathrm{Si}_{11}-\mathrm{Al}_{6}=2.491(2), \mathrm{Si}_{12}-\mathrm{Al}_{6}=2.474(2)$, $\mathrm{Al}_{7}-\mathrm{N}_{1}=2.221(5), \mathrm{Al}_{7}-\mathrm{N}_{4}=2.221(5), \mathrm{Al}_{7}-\mathrm{N}_{2}=2.224(5), \mathrm{Al}_{7}-\mathrm{N}_{3}=2.231(5), \mathrm{Al}_{7}-\mathrm{H}_{\mathrm{I}}=$ 1.584(0), $\mathrm{Al}_{7}-\mathrm{H}_{\mathrm{J}}=1.496(0)$. Selected bond angles $\left(^{\circ}\right): \mathrm{Al}_{6}-\mathrm{H}_{\mathrm{F}}-\mathrm{Al}_{5}=149.0(0), \mathrm{Si}_{10}-\mathrm{Al}_{5}-\mathrm{Si}_{9}$ $=116.50(10), \mathrm{Si}_{12}-\mathrm{Al}_{6}-\mathrm{Si}_{11}=111.9(8), \mathrm{N}_{1}-\mathrm{Al}_{7}-\mathrm{N}_{2}=83.5(19), \mathrm{N}_{1}-\mathrm{N}_{2}-\mathrm{N}_{3}-\mathrm{N}_{4}=2.4(0), \mathrm{Si}_{11}-$ $\mathrm{Al}_{6}-\mathrm{Si}_{12}-\mathrm{H}_{\mathrm{H}}=132.3(0), \mathrm{Si}_{11}-\mathrm{Al}_{6}-\mathrm{H}_{\mathrm{F}}-\mathrm{Al}_{5}=145.3(0)$.

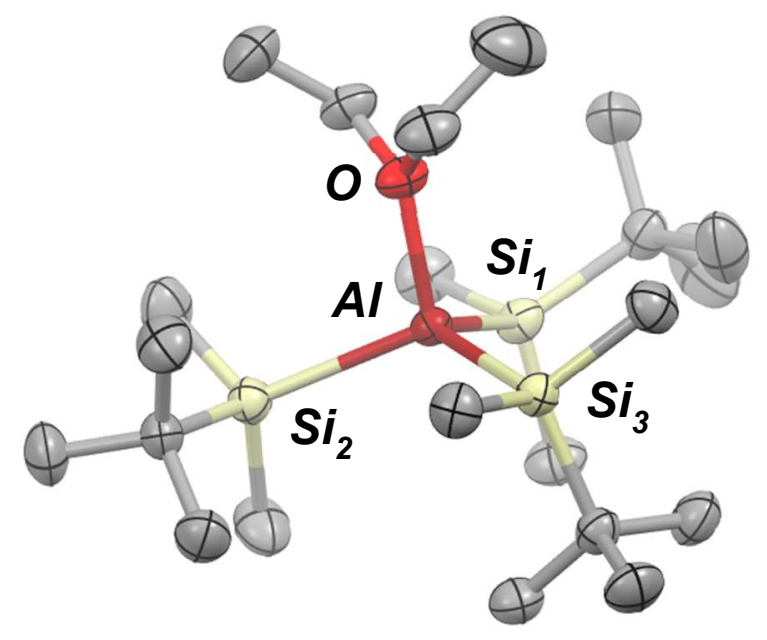

Figure S74. Solid state molecular structure of complex 12-Et $\mathbf{2} \mathbf{O}$. Hydrogen atoms omitted for clarity. Selected bond lengths $(\AA): \mathrm{Si}_{1}-\mathrm{Al}=2.512(9), \mathrm{Si}_{2}-\mathrm{Al}=2.515(15), \mathrm{Si}_{3}-\mathrm{Al}=$ $2.519(11), \mathrm{Al}-\mathrm{O}=1.978(17)$. Selected bond angles $\left(^{\circ}\right): \mathrm{Si}_{1}-\mathrm{Al}-\mathrm{Si}_{2}=103.8(4), \mathrm{Si}_{1}-\mathrm{Al}-\mathrm{Si}_{3}=$ 117.8(5), $\mathrm{Si}_{2}-\mathrm{Al}-\mathrm{Si}_{3}=120.3(4), \mathrm{O}-\mathrm{Al}-\mathrm{Si}_{1}=106.8(5), \mathrm{O}-\mathrm{Al}-\mathrm{Si}_{3}=102.9(5), \mathrm{O}-\mathrm{Al}-\mathrm{Si}_{2}=$ 103.5(7), $\mathrm{Si}_{1}-\mathrm{Al}_{-}-\mathrm{Si}_{2}-\mathrm{Si}_{3}=134.5(0), \mathrm{O}-\mathrm{Al}_{-} \mathrm{Si}_{3}-\mathrm{Si}_{2}=114.3(0)$. 


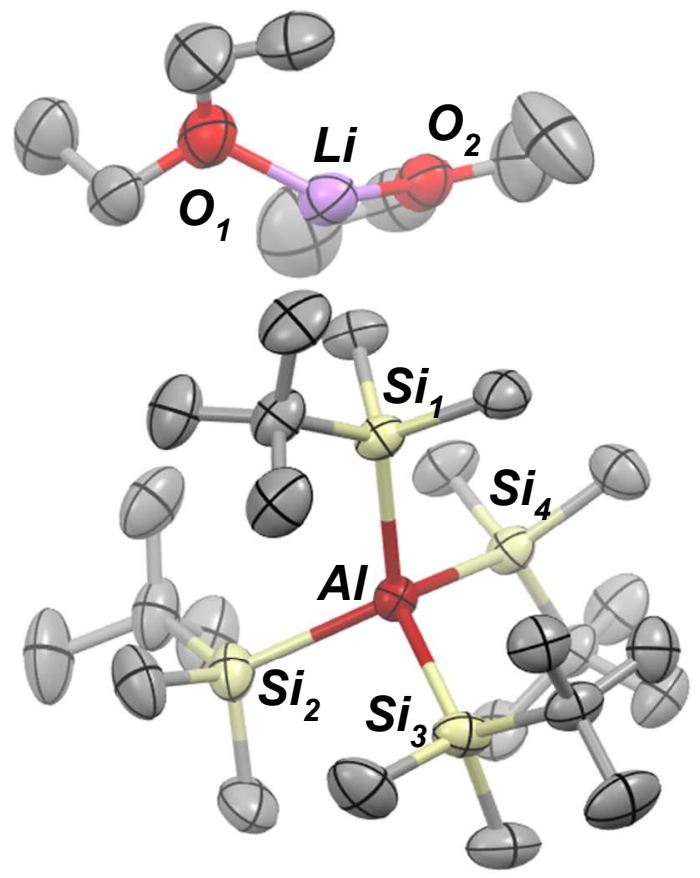

Figure S75. Solid state molecular structure of complex 14-Li(Et 20$)_{2}$. Hydrogen atoms omitted for clarity. Selected bond lengths $(\AA): \mathrm{Si}_{1}-\mathrm{Al}=2.530(13), \mathrm{Si}_{2}-\mathrm{Al}=2.513(14), \mathrm{Si}_{3}-$ $\mathrm{Al}=2.521(13), \mathrm{Si}_{4}-\mathrm{Al}=2.531(13), \mathrm{Al}-\mathrm{Li}$ 5.722(0), $\mathrm{O}_{1}-\mathrm{Li}=1.871(7), \mathrm{O}_{2}-\mathrm{Li}=1.894(7)$. Selected bond angles $\left(^{\circ}\right): \mathrm{Si}_{1}-\mathrm{Al}-\mathrm{Si}_{4}=100.5(5), \mathrm{Si}_{2}-\mathrm{Al}_{-}-\mathrm{Si}_{1}=114.6(5), \mathrm{Si}_{2}-\mathrm{Al}_{1}-\mathrm{Si}_{3}=99.5(5)$, $\mathrm{Si}_{2}-\mathrm{Al}_{-}-\mathrm{Si}_{4}=114.9(5), \mathrm{Si}_{3}-\mathrm{Al}-\mathrm{Si}_{1}=113.5(5), \mathrm{Si}_{3}-\mathrm{Al}_{-} \mathrm{Si}_{4}=114.34(5), \mathrm{O}_{1}-\mathrm{Li}-\mathrm{O}_{2}=113.4(4)$, $\mathrm{Si}_{1}-\mathrm{Al}_{-} \mathrm{Si}_{4}-\mathrm{Si}_{3}=122.0(3)$.

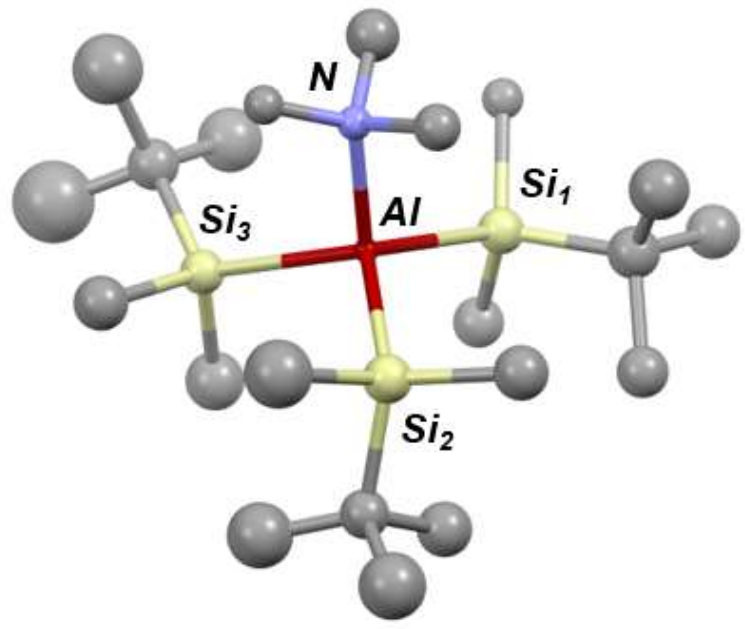

Figure S76. Solid state molecular structure of complex 16-NMe3. The refinement converged at ca. $\mathrm{R}=20 \%$ this was adequate merely to confirm that a $\mathrm{NMe}_{3}$ molecule is coordinated to a trisilyl aluminum molecule. Therefore, no geometric parameters are given. 
Table S1. Crystallographic Determination and Refinement Data for 2-NMe3, 3, 5-Br and 10.

\begin{tabular}{|c|c|c|c|c|}
\hline Name & $2-\mathrm{NMe}_{3}$ & 3 & $5-\mathrm{Br}$ & 10 \\
\hline Empirical formula & $\mathrm{C}_{15} \mathrm{H}_{39} \mathrm{AlClNSi}_{2}$ & $\mathrm{C}_{17} \mathrm{H}_{42} \mathrm{AlCl}_{2} \mathrm{NSi}_{3}$ & $\mathrm{C}_{24} \mathrm{H}_{60} \mathrm{Al}_{2} \mathrm{Br}_{2} \mathrm{Si}_{4}$ & $\mathrm{C}_{78} \mathrm{H}_{204} \mathrm{Al}_{12} \mathrm{Si}_{12}$ \\
\hline Formula weight & 352.08 & 442.66 & 674.86 & 1803.25 \\
\hline Temperature, $\mathrm{K}$ & $200(2)$ & 200.15 & $200(2)$ & 200.15 \\
\hline Crystal system & monoclinic & triclinic & monoclinic & monoclinic \\
\hline Space group & $\mathrm{P} 2{ }_{1} / \mathrm{c}$ & P-1 & $\mathrm{P} 2{ }_{1} / \mathrm{c}$ & $\mathrm{P} 2{ }_{1} / \mathrm{n}$ \\
\hline $\mathrm{a}, \AA$ & $7.6120(2)$ & $12.3464(7)$ & $7.6080(5)$ & $16.9507(9)$ \\
\hline $\mathrm{b}, \AA$ & $21.2340(5)$ & $13.7331(8)$ & $18.684(3)$ & $19.7500(11)$ \\
\hline $\mathrm{c}, \AA$ & $15.2500(3)$ & $15.5086(9)$ & $14.5410(15)$ & $19.5077(11)$ \\
\hline$\alpha, \operatorname{deg}$ & 90.00 & $93.5950(10)$ & 90.00 & 90 \\
\hline$\beta, \operatorname{deg}$ & $112.4801(13)$ & $94.6840(10)$ & $114.703(6)$ & $103.792(2)$ \\
\hline$\Gamma, \operatorname{deg}$ & 90.00 & $90.986(2)$ & 90.00 & 90 \\
\hline Volume, $\AA^{3}$ & $2277.60(9)$ & $2615.0(3)$ & $1877.8(3)$ & $6342.4(6)$ \\
\hline $\mathrm{Z}$ & 4 & 4 & 2 & 2 \\
\hline$\rho$ (cacld.), $\mathrm{g} / \mathrm{cm}^{3}$ & 1.027 & 1.124 & 1.194 & 0.944 \\
\hline$\mu(\mathrm{Mo} \mathrm{K} \alpha), \mathrm{mm}^{-1}$ & 0.306 & 0.422 & 2.344 & 0.236 \\
\hline$F(000)$ & 776.0 & 960.0 & 712.0 & 1992.0 \\
\hline Crystal size $/ \mathrm{mm}^{3}$ & $0.33 \times 0.18 \times 0.15$ & $0.21 \times 0.18 \times 0.18$ & $0.30 \times 0.12 \times 0.09$ & $0.21 \times 0.18 \times 0.12$ \\
\hline Radiation $(\lambda, \AA)$ & $\operatorname{MoK} \alpha(\lambda=0.71073)$ & $\operatorname{MoK} \alpha(\lambda=0.71073)$ & $\operatorname{MoK} \alpha(\lambda=0.71073)$ & $\operatorname{MoK} \alpha(\lambda=0.71073)$ \\
\hline $2 \Theta$ range for data collection $/{ }^{\circ}$ & 3.46 to 50 & 2.64 to 50.516 & 5.34 to 48.8 & 2.864 to 49.592 \\
\hline Index ranges & $\begin{array}{c}0 \leq \mathrm{h} \leq 9,-25 \leq \mathrm{k} \leq 0 \\
-18 \leq 1 \leq 15\end{array}$ & $\begin{array}{c}-14 \leq \mathrm{h} \leq 14,-16 \leq \mathrm{k} \\
\leq 16,-18 \leq 1 \leq 18\end{array}$ & $\begin{array}{c}0 \leq \mathrm{h} \leq 8,-21 \leq \mathrm{k} \leq 0, \\
-16 \leq 1 \leq 14\end{array}$ & $\begin{array}{c}-19 \leq \mathrm{h} \leq 19,-23 \leq \mathrm{k} \leq 19 \\
-22 \leq 1 \leq 23\end{array}$ \\
\hline Reflections collected & 3978 & 24173 & 2909 & 43657 \\
\hline Independent reflections & $\begin{array}{c}3978\left[\mathrm{R}_{\text {int }}=0.0440,\right. \\
\left.\mathrm{R}_{\text {sigma }}=0.0481\right]\end{array}$ & $\begin{array}{c}9350\left[\mathrm{R}_{\mathrm{int}}=0.1110,\right. \\
\left.\mathrm{R}_{\mathrm{sigma}}=0.1472\right]\end{array}$ & $\begin{array}{c}2909\left[\mathrm{R}_{\text {int }}=0.0580\right. \\
\left.\mathrm{R}_{\mathrm{sigma}}=0.0791\right]\end{array}$ & $\begin{array}{c}10881\left[\mathrm{R}_{\text {int }}=0.1345,\right. \\
\left.\mathrm{R}_{\text {sigma }}=0.1262\right]\end{array}$ \\
\hline Data/restraints/parameters & $3978 / 0 / 194$ & $9350 / 0 / 457$ & $2909 / 0 / 155$ & $10881 / 0 / 514$ \\
\hline Goodness-of-fit on $\mathrm{F}^{2}$ & 1.059 & 0.859 & 0.960 & 0.972 \\
\hline Final $R$ indexes $[\mathrm{I}>=2 \sigma(\mathrm{I})]$ & $\begin{array}{c}\mathrm{R}_{1}=0.0474, \mathrm{wR}_{2}= \\
0.1205\end{array}$ & $\begin{array}{c}\mathrm{R}_{1}=0.0497, \mathrm{wR}_{2}= \\
0.1133\end{array}$ & $\begin{array}{c}\mathrm{R}_{1}=0.0434 \\
\mathrm{wR}_{2}=0.0833\end{array}$ & $\begin{array}{c}\mathrm{R}_{1}=0.0938 \\
\mathrm{wR}_{2}=0.2161\end{array}$ \\
\hline Final $\mathrm{R}$ indexes [all data] & $\begin{array}{c}\mathrm{R}_{1}=0.0742, \mathrm{wR}_{2}= \\
0.1340\end{array}$ & $\begin{array}{c}\mathrm{R}_{1}=0.0833, \mathrm{wR}_{2}= \\
0.1260\end{array}$ & $\begin{array}{c}\mathrm{R}_{1}=0.0839 \\
\mathrm{wR}_{2}=0.0918\end{array}$ & $\begin{array}{l}\mathrm{R}_{1}=0.1653 \\
\mathrm{wR}_{2}=0.2331\end{array}$ \\
\hline
\end{tabular}


Table S2. Crystallographic Determination and Refinement Data for 11, 12-Et ${ }_{2} \mathrm{O}, 14-\mathrm{Li}\left(\mathrm{Et}_{2} \mathrm{O}\right)_{2}$ and $16-\mathrm{NMe}_{3}$.

\begin{tabular}{|c|c|c|c|c|}
\hline Name & 11 & 12- $\mathrm{Et}_{2} \mathrm{O}$ & $14-\mathrm{Li}\left(\mathrm{Et}_{2} \mathrm{O}\right)_{2}$ & $16-\mathrm{NMe}_{3}$ \\
\hline Empirical formula & $\mathrm{C}_{36} \mathrm{H}_{97} \mathrm{Al}_{3} \mathrm{~N}_{4} \mathrm{Si}_{4}$ & $\mathrm{C}_{22} \mathrm{H}_{55} \mathrm{AlOSi}_{3}$ & $\mathrm{C}_{32} \mathrm{H}_{80} \mathrm{AlLiO}_{2} \mathrm{Si}_{4}$ & $\mathrm{C}_{18} \mathrm{H}_{15} \mathrm{AlNSi}_{3}$ \\
\hline Formula weight & 779.47 & 446.91 & 643.24 & 356.56 \\
\hline Temperature, $\mathrm{K}$ & $200(2)$ & $200(2)$ & 200.15 & 296.15 \\
\hline Crystal system & monoclinic & monoclinic & monoclinic & orthorhombic \\
\hline Space group & $\mathrm{P} 2 / \mathrm{c}$ & $\mathrm{C} 2 / \mathrm{c}$ & $\mathrm{P} 2{ }_{1} / \mathrm{c}$ & Pna $2_{1}$ \\
\hline $\mathrm{a}, \AA$ & $20.6147(12)$ & $27.094(11)$ & $11.0140(2)$ & $16.961(5)$ \\
\hline $\mathrm{b}, \AA$ & $33.5541(18)$ & $16.121(4)$ & $20.2250(5)$ & $30.335(8)$ \\
\hline $\mathrm{c}, \AA$ & $23.6676(13)$ & $18.557(13)$ & $20.7510(6)$ & $17.588(5)$ \\
\hline$\alpha, \operatorname{deg}$ & 90 & 90.00 & 90 & 90 \\
\hline$\beta, \operatorname{deg}$ & $96.849(2)$ & $132.192(12)$ & $99.7290(9)$ & 90 \\
\hline$\Gamma, \operatorname{deg}$ & 90 & 90.00 & 90 & 90 \\
\hline Volume, $\AA^{3}$ & $16254.2(16)$ & $6005(5)$ & $4555.97(19)$ & $9050(4)$ \\
\hline $\mathrm{Z}$ & 12 & 8 & 4 & 21 \\
\hline$\rho$ (cacld.), $\mathrm{g} / \mathrm{cm}^{3}$ & 0.956 & 0.989 & 0.938 & 1.374 \\
\hline$\mu(\mathrm{Mo} \mathrm{K} \alpha), \mathrm{mm}^{-1}$ & 0.183 & 0.197 & 0.172 & 0.324 \\
\hline$F(000)$ & 5232.0 & 2000.0 & 1440.0 & 3885.0 \\
\hline Crystal size $/ \mathrm{mm}^{3}$ & $0.330 \times 0.240 \times 0.210$ & $0.36 \times 0.33 \times 0.30$ & $0.27 \times 0.21 \times 0.18$ & $? \times ? \times ?$ \\
\hline Radiation $(\lambda, \AA)$ & $\operatorname{MoK} \alpha(\lambda=0.71073)$ & $\operatorname{MoK} \alpha(\lambda=0.71073)$ & $\operatorname{MoK} \alpha(\lambda=0.71073)$ & $\operatorname{MoK} \alpha(\lambda=0.71073)$ \\
\hline $2 \Theta$ range for data collection $/{ }^{\circ}$ & 1.99 to 50.26 & 3.24 to 50.02 & 4.464 to 49.418 & 2.676 to 47.422 \\
\hline Index ranges & $\begin{array}{c}-22 \leq \mathrm{h} \leq 24,-39 \leq \mathrm{k} \leq \\
39,-28 \leq 1 \leq 16\end{array}$ & $\begin{array}{c}0 \leq \mathrm{h} \leq 32,0 \leq \mathrm{k} \leq 19, \\
-22 \leq 1 \leq 16\end{array}$ & $\begin{array}{c}0 \leq \mathrm{h} \leq 12,0 \leq \mathrm{k} \leq 23,24 \leq \\
1 \leq-24\end{array}$ & $\begin{array}{c}-19 \leq \mathrm{h} \leq 19,-34 \leq \mathrm{k} \leq 34,- \\
19 \leq 1 \leq 19\end{array}$ \\
\hline Reflections collected & 85363 & 5253 & 7751 & $4 \overline{7603}$ \\
\hline Independent reflections & $\begin{array}{c}28389\left[\mathrm{R}_{\text {int }}=0.1186,\right. \\
\left.\mathrm{R}_{\text {sigma }}=0.1948\right]\end{array}$ & $\begin{array}{c}5253\left[\mathrm{R}_{\text {int }}=0.0530,\right. \\
\left.\mathrm{R}_{\text {sigma }}=0.0371\right]\end{array}$ & $\begin{aligned} 7751\left[\mathrm{R}_{\text {int }}=\right. & 0.0720, \mathrm{R}_{\text {sigma }}= \\
& 0.0623]\end{aligned}$ & $\begin{array}{c}13581\left[R_{\text {int }}=0.1229, R_{\text {sigma }}\right. \\
=0.1453]\end{array}$ \\
\hline Data/restraints/parameters & $28389 / 6 / 1340$ & $5253 / 0 / 261$ & $7751 / 116 / 425$ & $13581 / 1 / 289$ \\
\hline Goodness-of-fit on $\mathrm{F}^{2}$ & 0.917 & 1.082 & 1.034 & 1.585 \\
\hline Final $R$ indexes $[\mathrm{I}>=2 \sigma(\mathrm{I})]$ & $\begin{array}{c}\mathrm{R}_{1}=0.0819 \\
\mathrm{wR}_{2}=0.1893\end{array}$ & $\begin{array}{c}\mathrm{R}_{1}=0.0459, \mathrm{wR}_{2}= \\
0.1237\end{array}$ & $\mathrm{R}_{1}=0.0741, \mathrm{wR}_{2}=0.1442$ & $\begin{array}{c}\mathrm{R}_{1}=0.1967 \\
\mathrm{wR}_{2}=0.4566\end{array}$ \\
\hline Final $\mathrm{R}$ indexes [all data] & $\begin{array}{c}\mathrm{R}_{1}=0.2014 \\
\mathrm{wR}_{2}=0.2378\end{array}$ & $\begin{array}{c}\mathrm{R}_{1}=0.0616, w \mathrm{R}_{2}= \\
0.1321\end{array}$ & $\mathrm{R}_{1}=0.1141, \mathrm{wR}_{2}=0.1596$ & $\begin{array}{c}\mathrm{R}_{1}=0.3085 \\
\mathrm{wR}_{2}=0.5263\end{array}$ \\
\hline
\end{tabular}




\section{Mass Spectrometry}

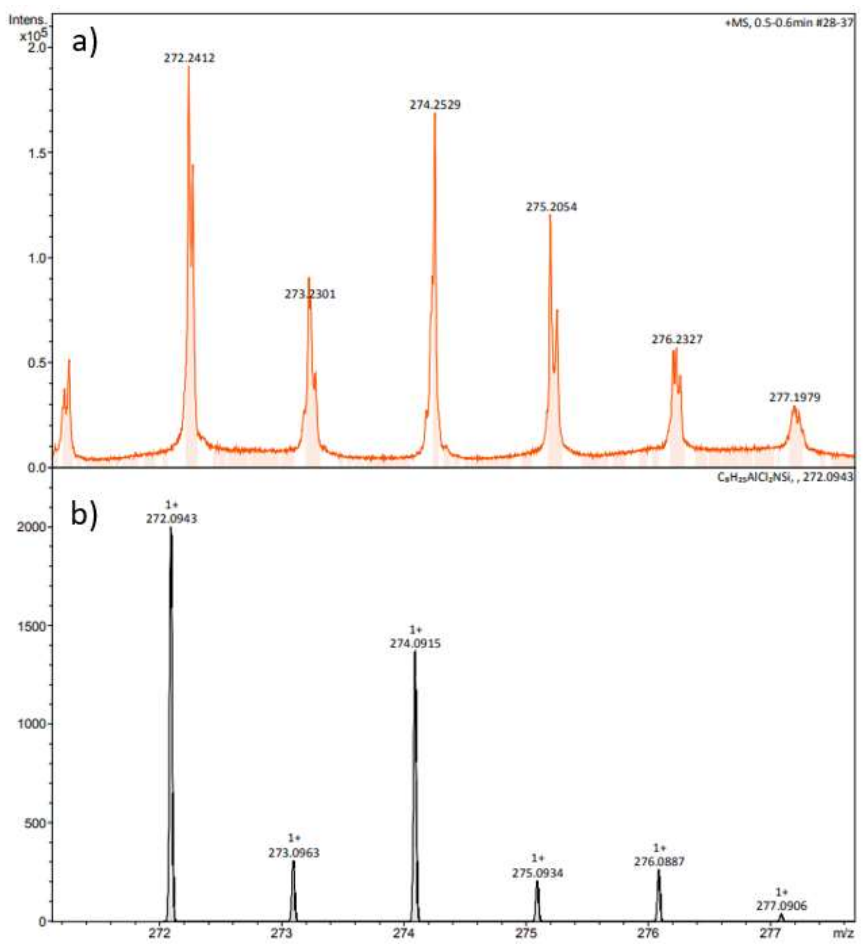

Figure S77. a) Measured and b) Simulated mass spectrum of 1-NMe3.

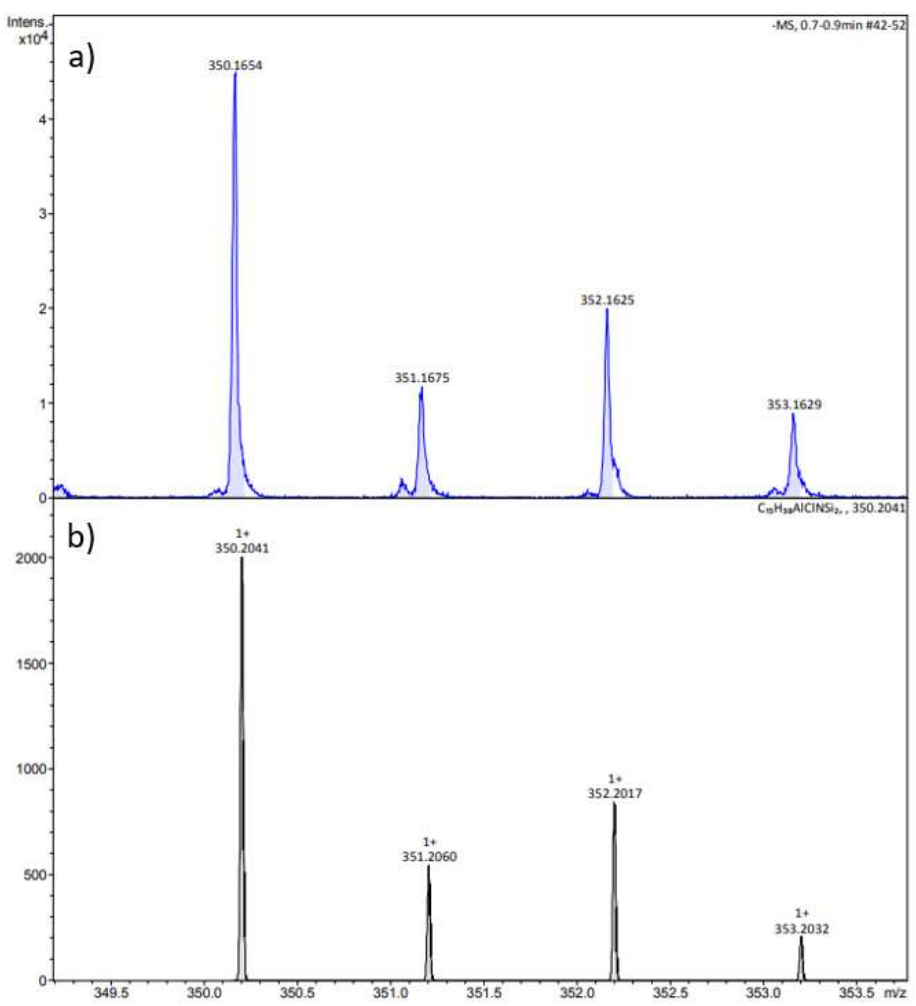

Figure S78. a) Measured and b) Simulated mass spectrum of 2-NMe3. 


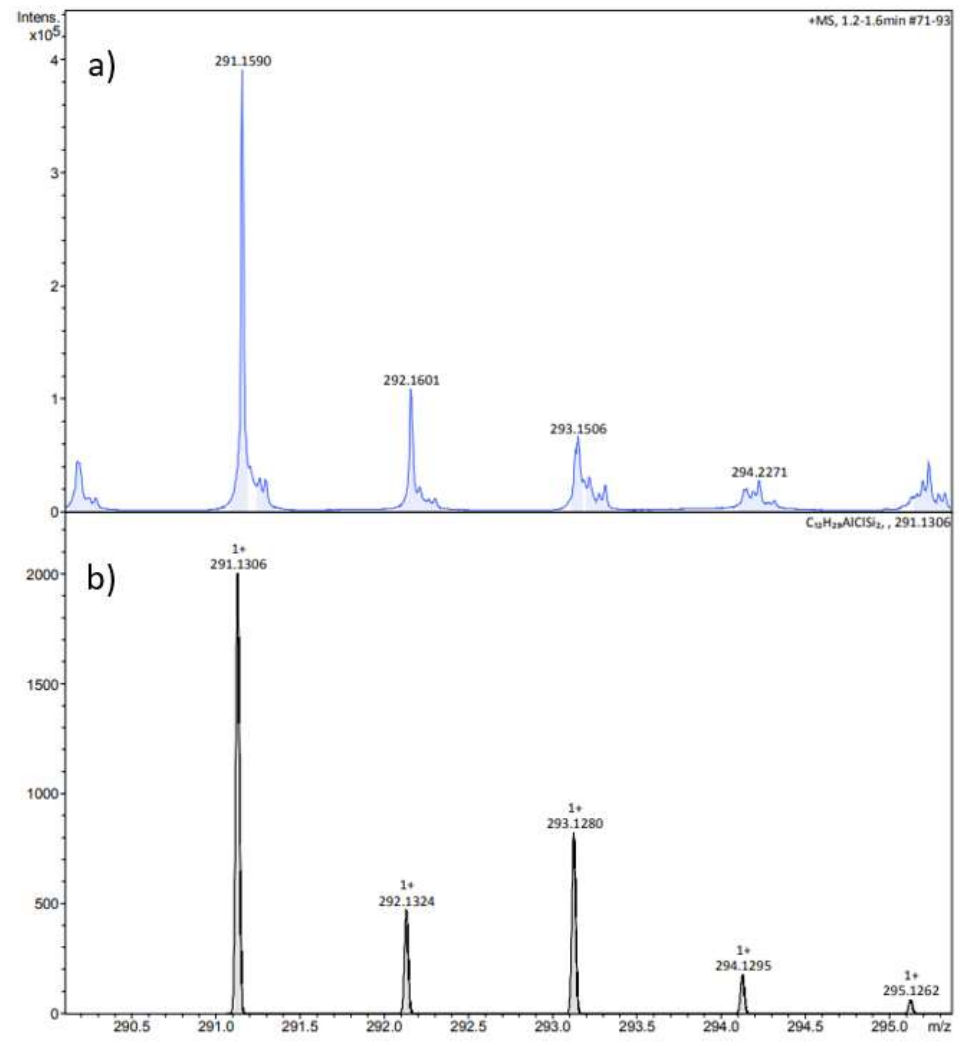

Figure S79. a) Measured and b) Simulated mass spectrum of 4-Cl.

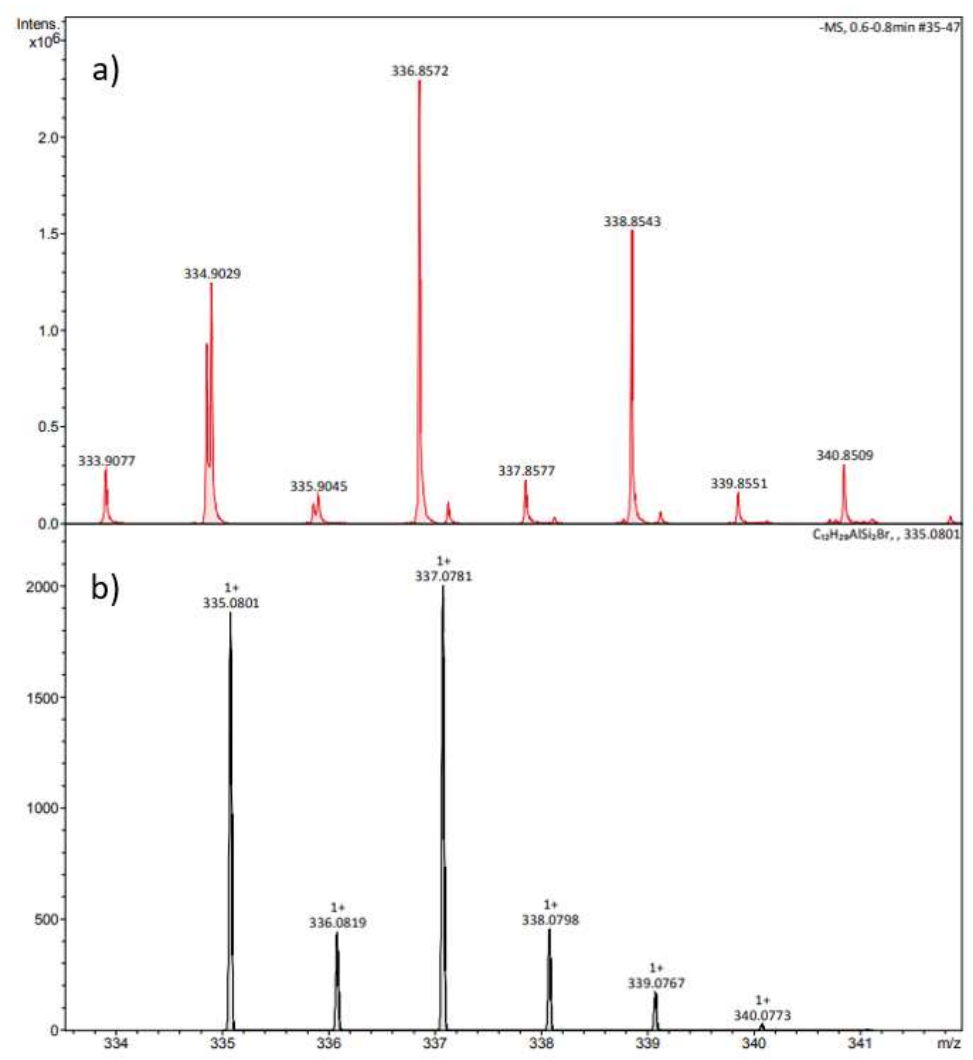

Figure S80. a) Measured and b) Simulated mass spectrum of 5-Br. 


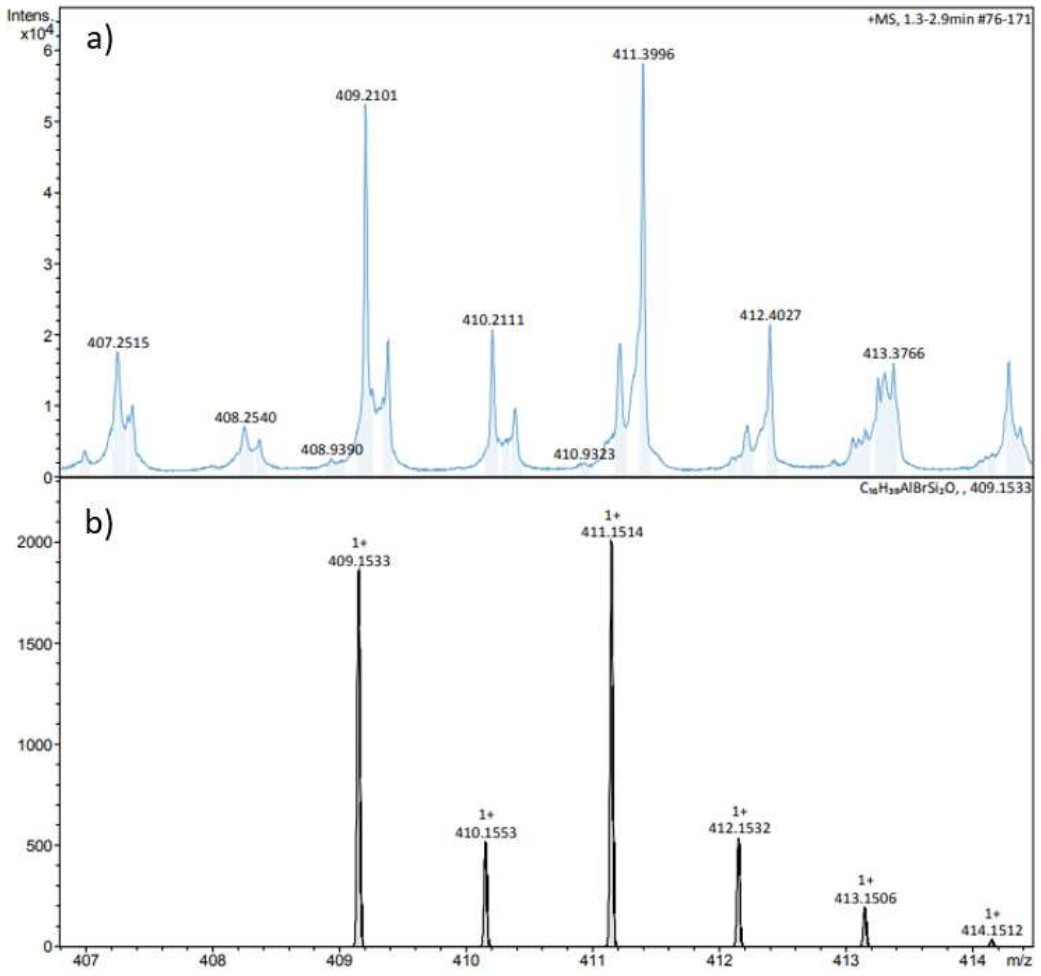

Figure S81. a) Measured and b) Simulated mass spectrum of 6-Br.

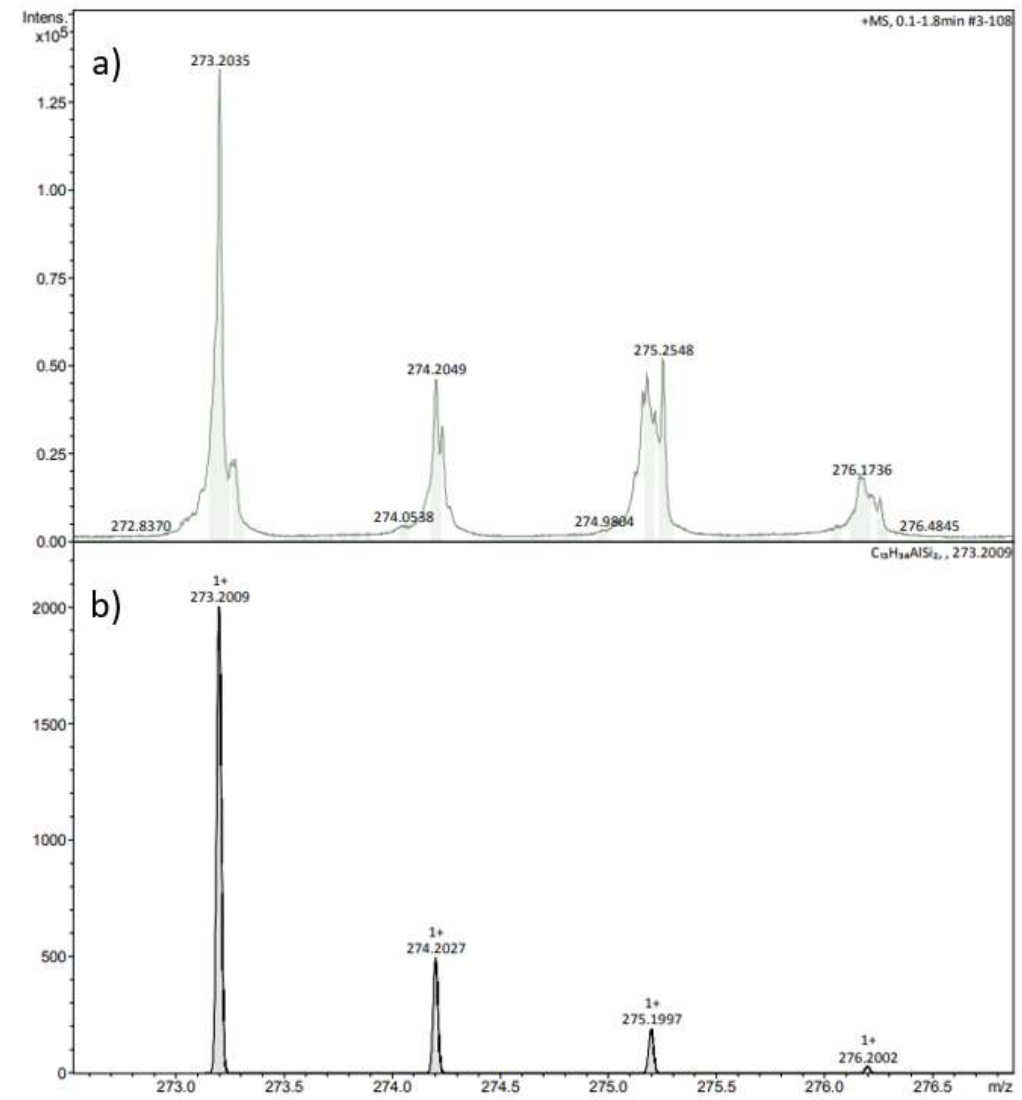

Figure S82. a) Measured and b) Simulated mass spectrum of 7. 


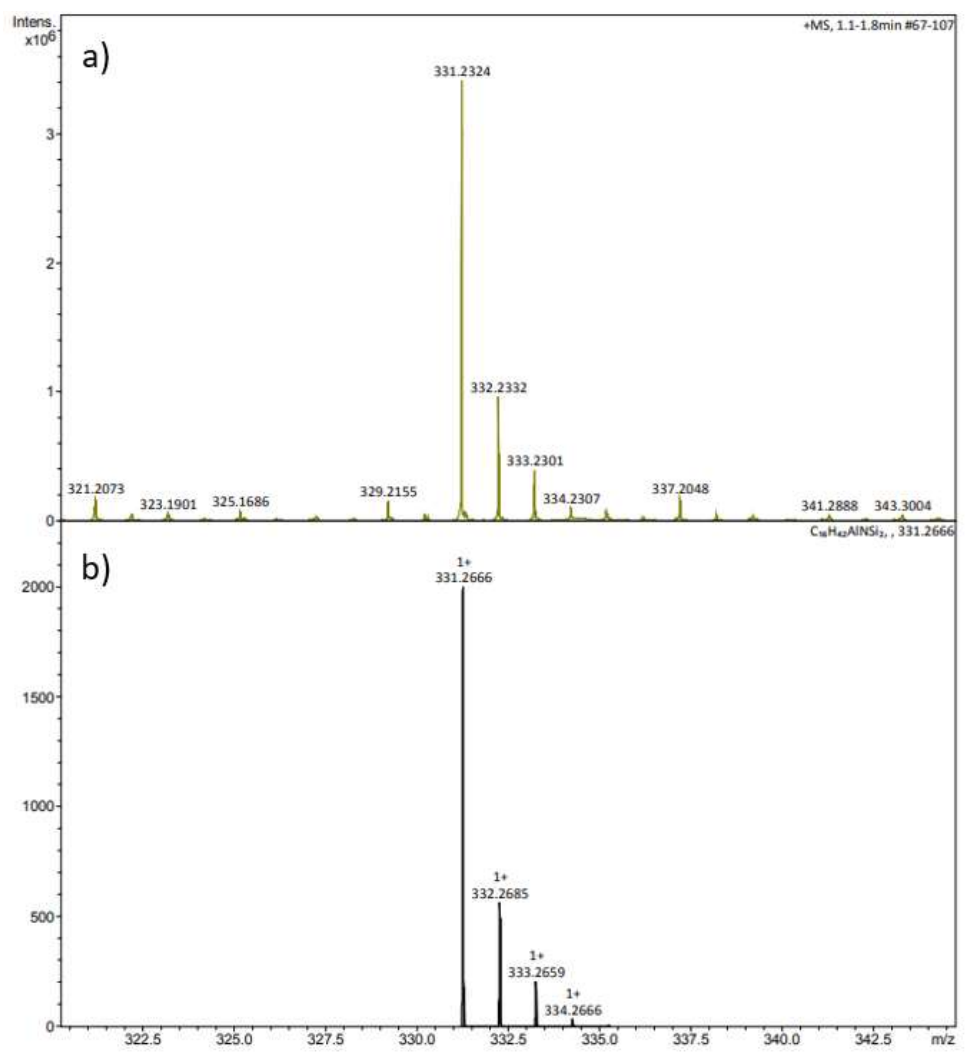

Figure S83. a) Measured and b) Simulated mass spectrum of 8-NMe3.

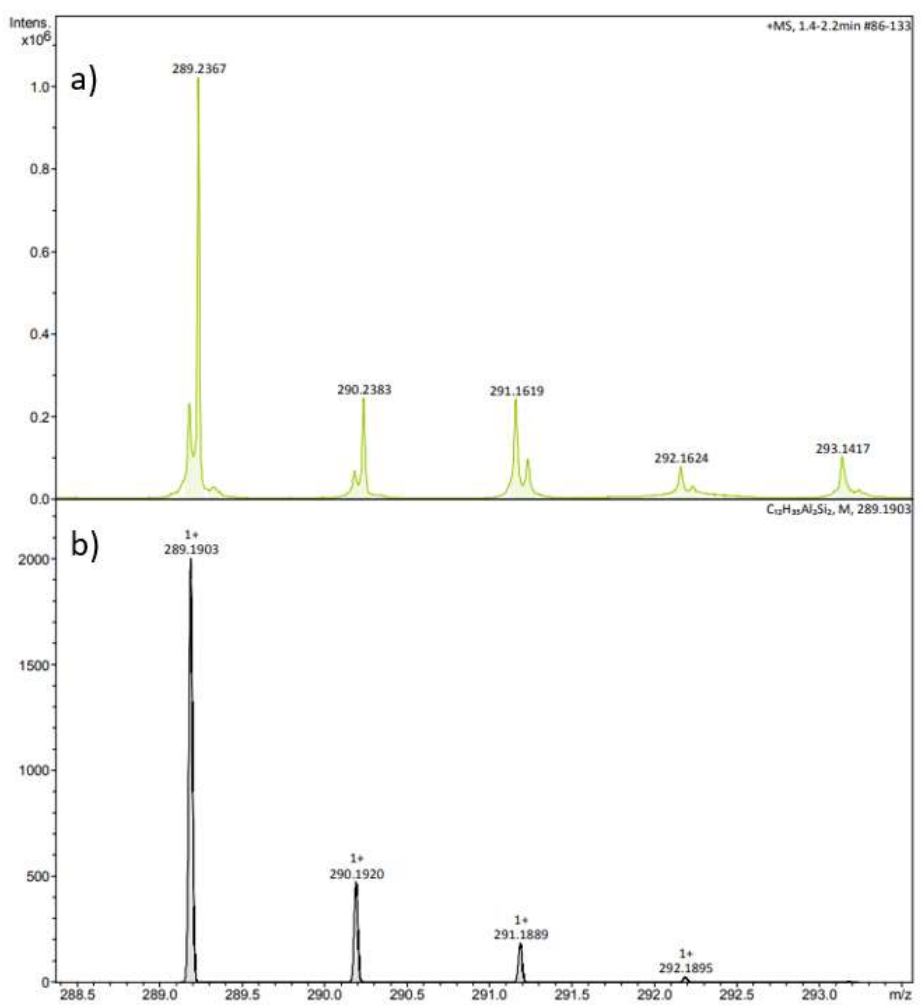

Figure S84. a) Measured and b) Simulated mass spectrum of a monomer [( $\left.{ }^{\mathrm{t}} \mathrm{BuMe}{ }_{2} \mathrm{Si}\right)_{2} \mathrm{Al}(\mu-$ $\left.\mathrm{H}) \mathrm{AlH}_{3}\right]$ of $\mathbf{1 0}$. 


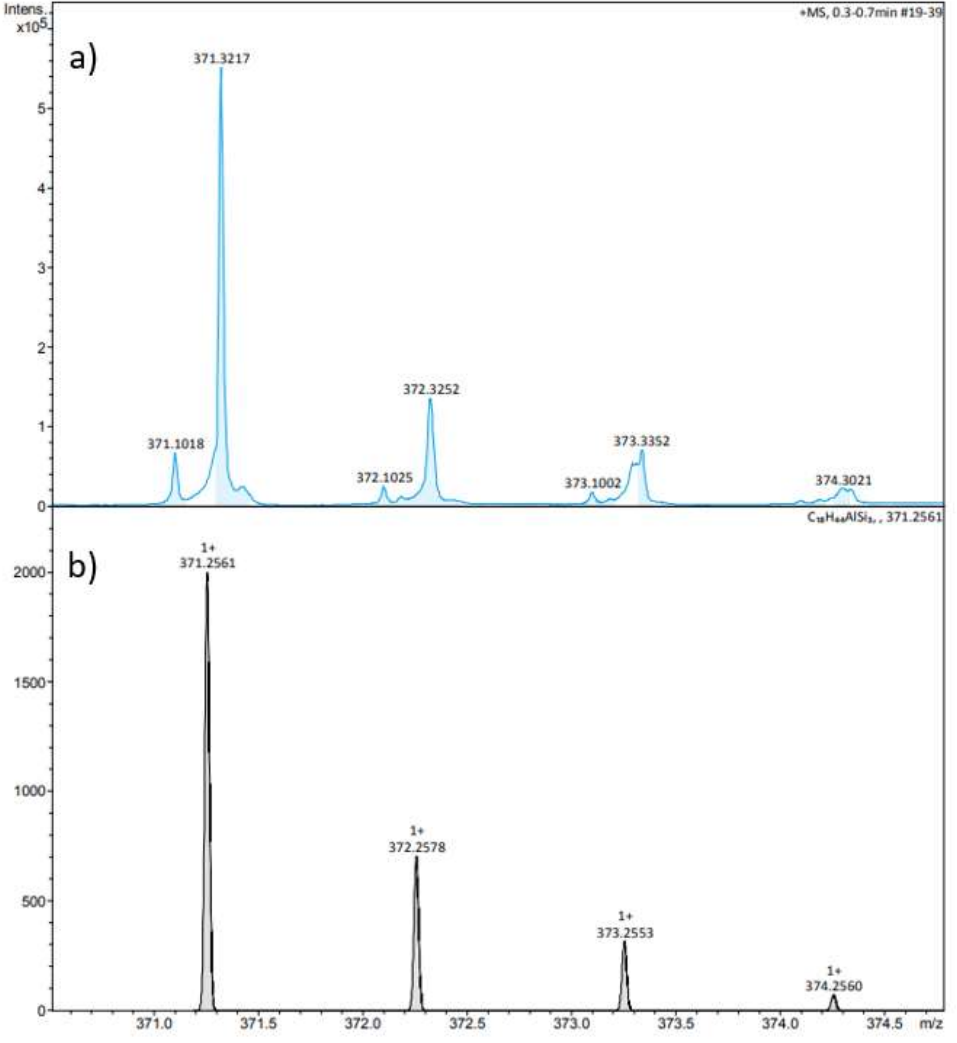

Figure S85. a) Measured and b) Simulated mass spectrum of 12-Et2O.

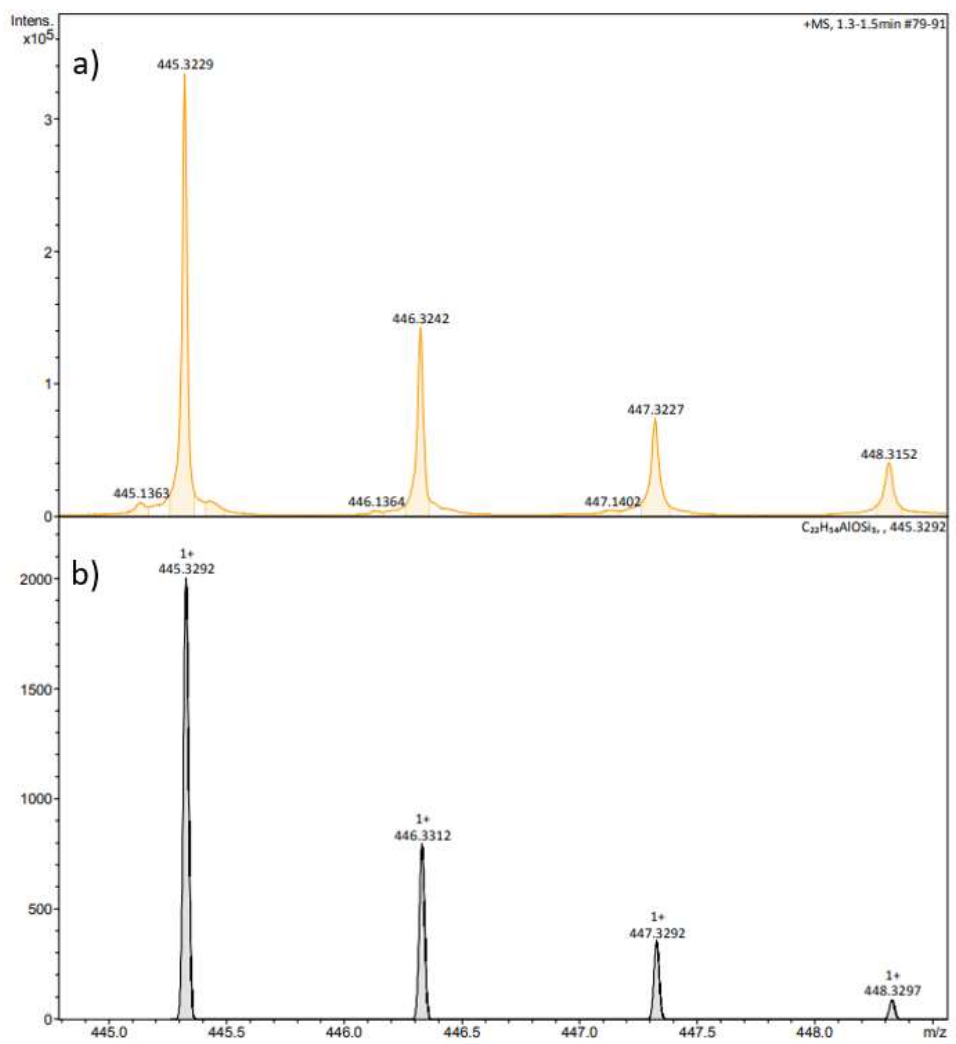

Figure S86. a) Measured and b) Simulated mass spectrum of 13-Et $\mathbf{t}_{2} \mathbf{O}$. 


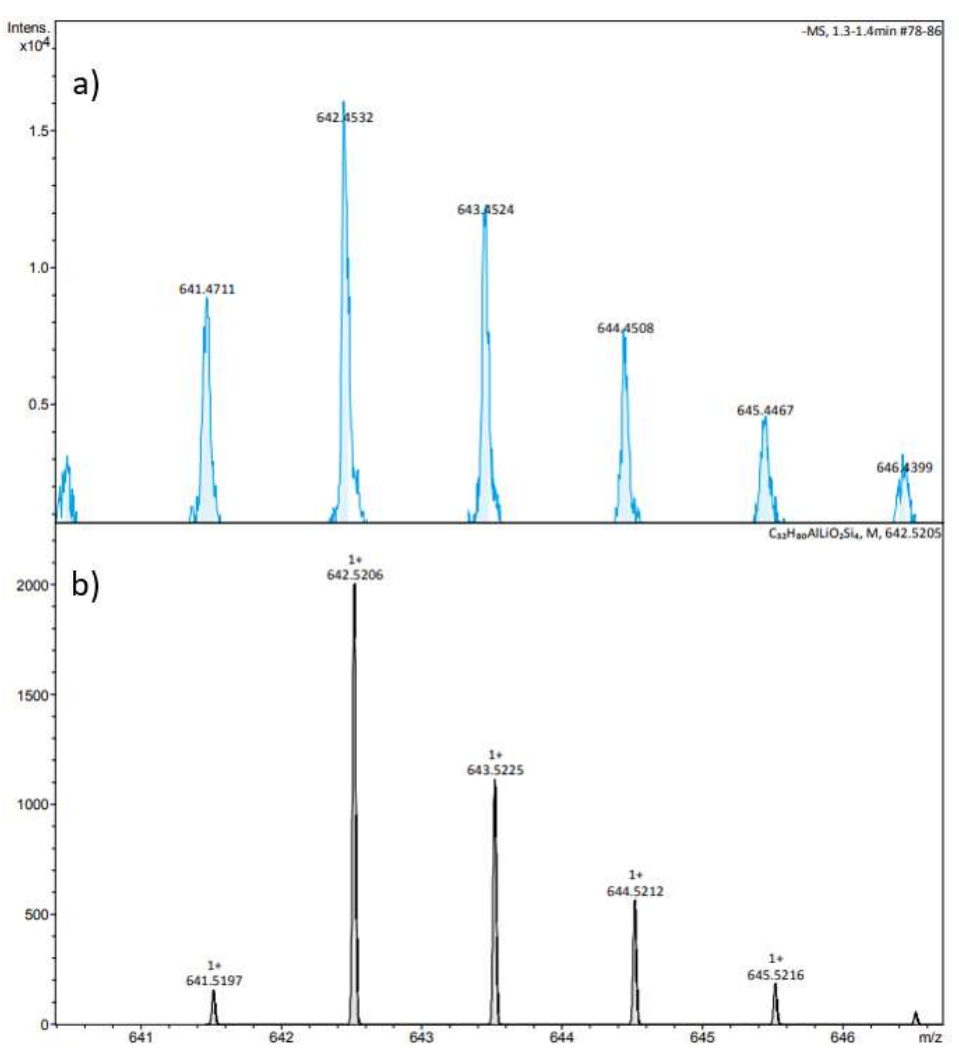

Figure S87. a) Measured and b) Simulated mass spectrum of 14-Li(Et $\left.\mathbf{E t}_{2} \mathbf{O}\right)_{2}$.

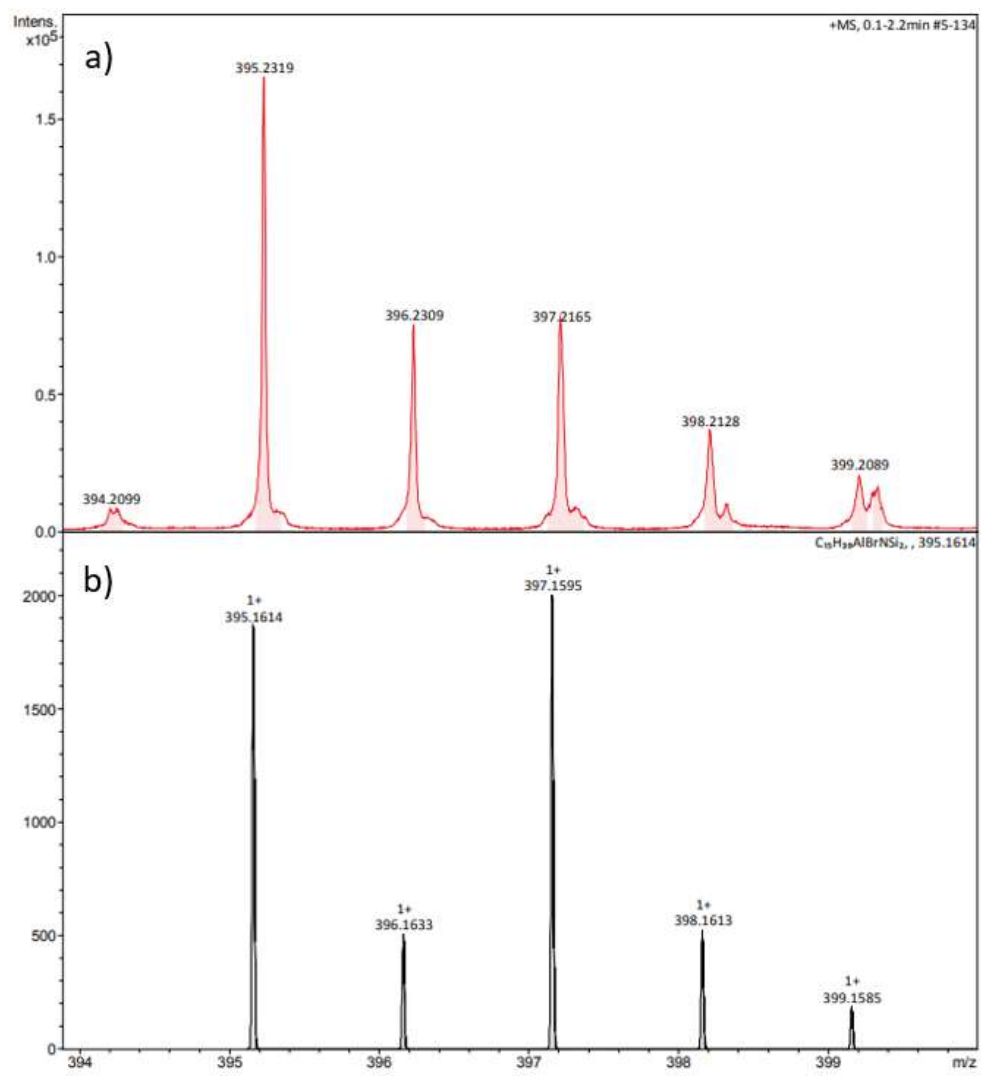

Figure S88. a) Measured and b) Simulated mass spectrum of 15-NMe3. 


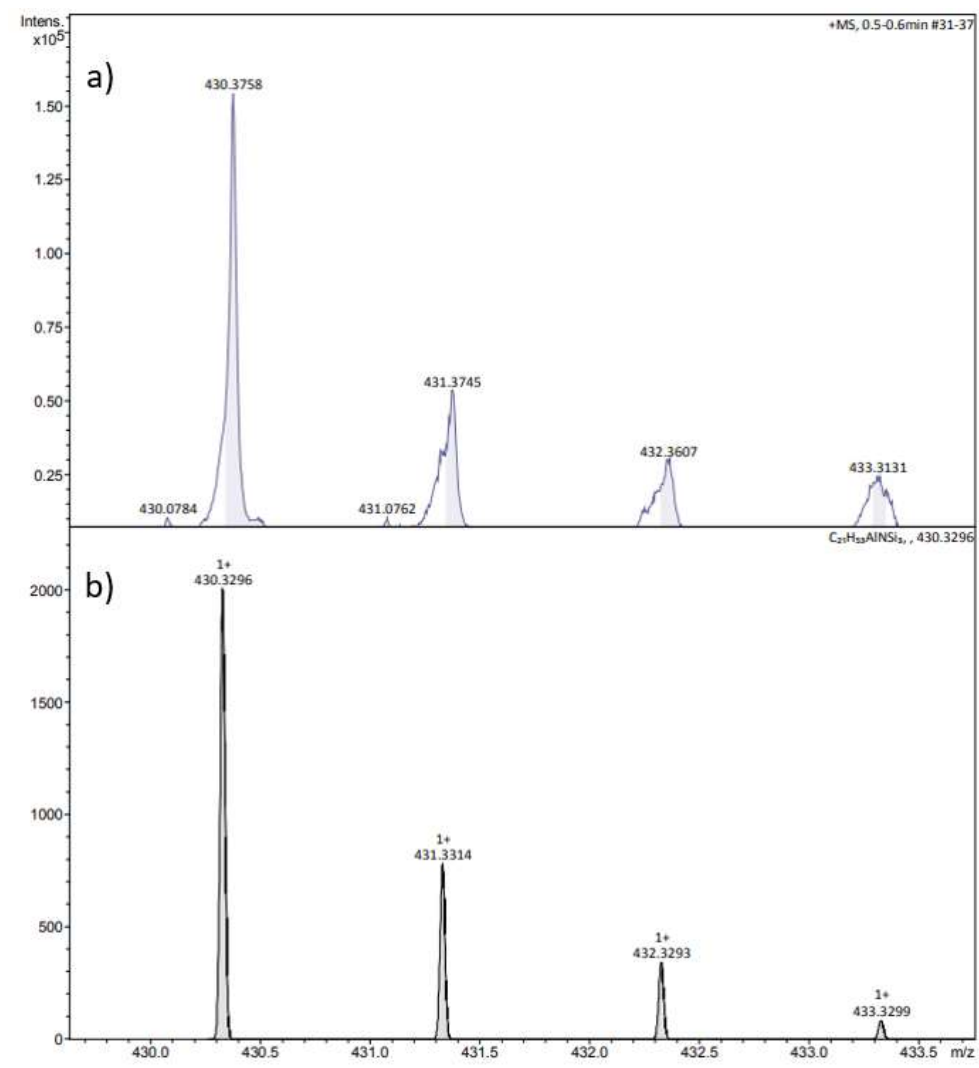

Figure S89. a) Measured and b) Simulated mass spectrum of 16-NMe3.

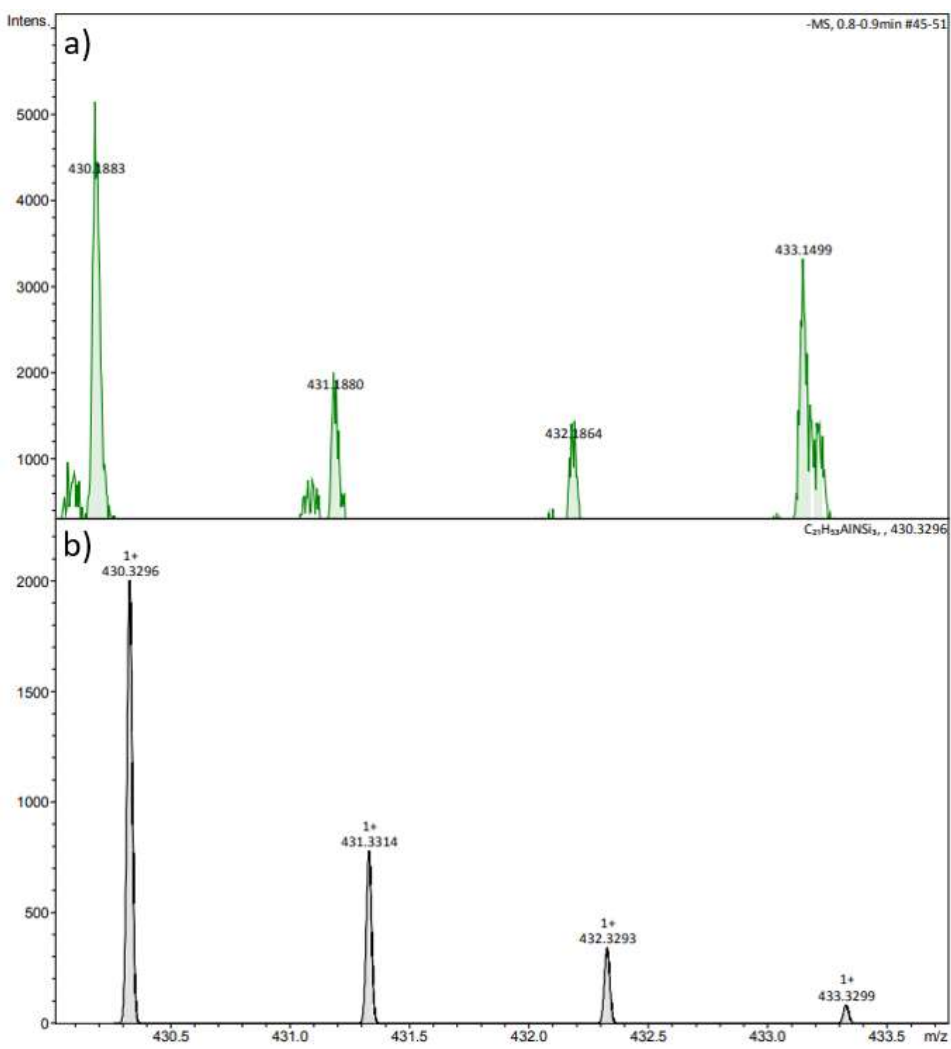

Figure S90. a) Measured and b) Simulated mass spectrum of 17-NMe3. 


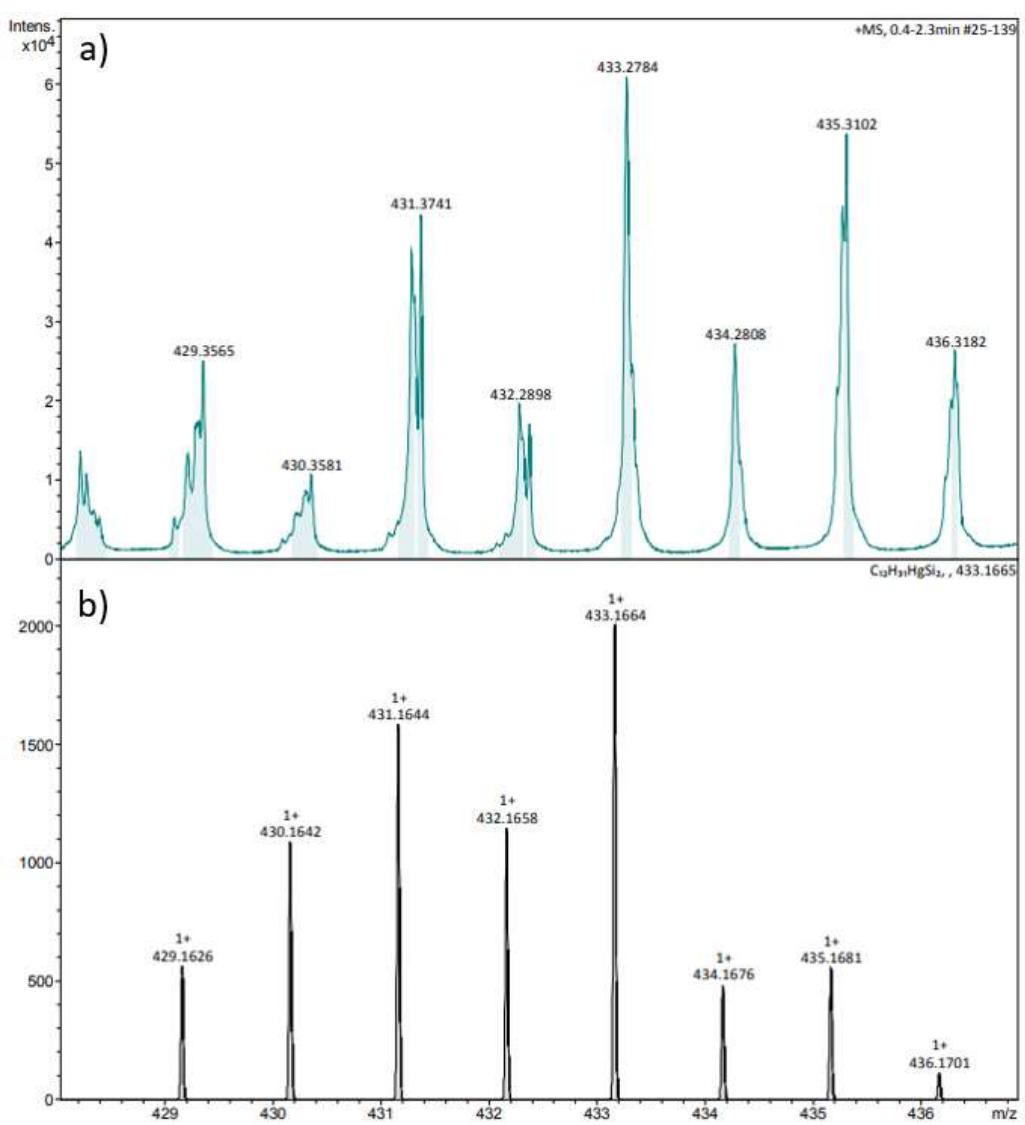

Figure S91. a) Measured and b) Simulated mass spectrum of (Et $\left.\mathbf{t}_{3} \mathbf{S i}\right)_{2} \mathbf{H g}$.

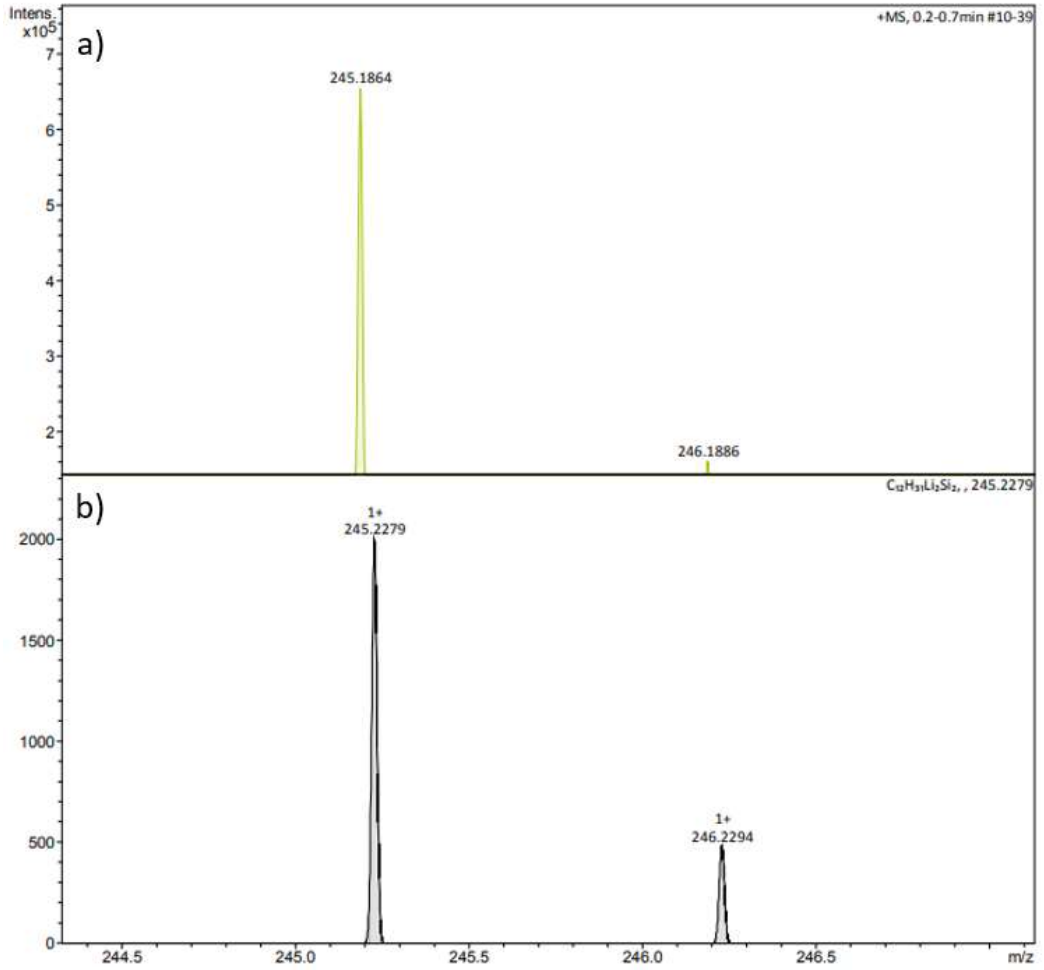

Figure S92. a) Measured and b) Simulated mass spectrum of Et $\mathbf{t}_{3}$ SiLi. 


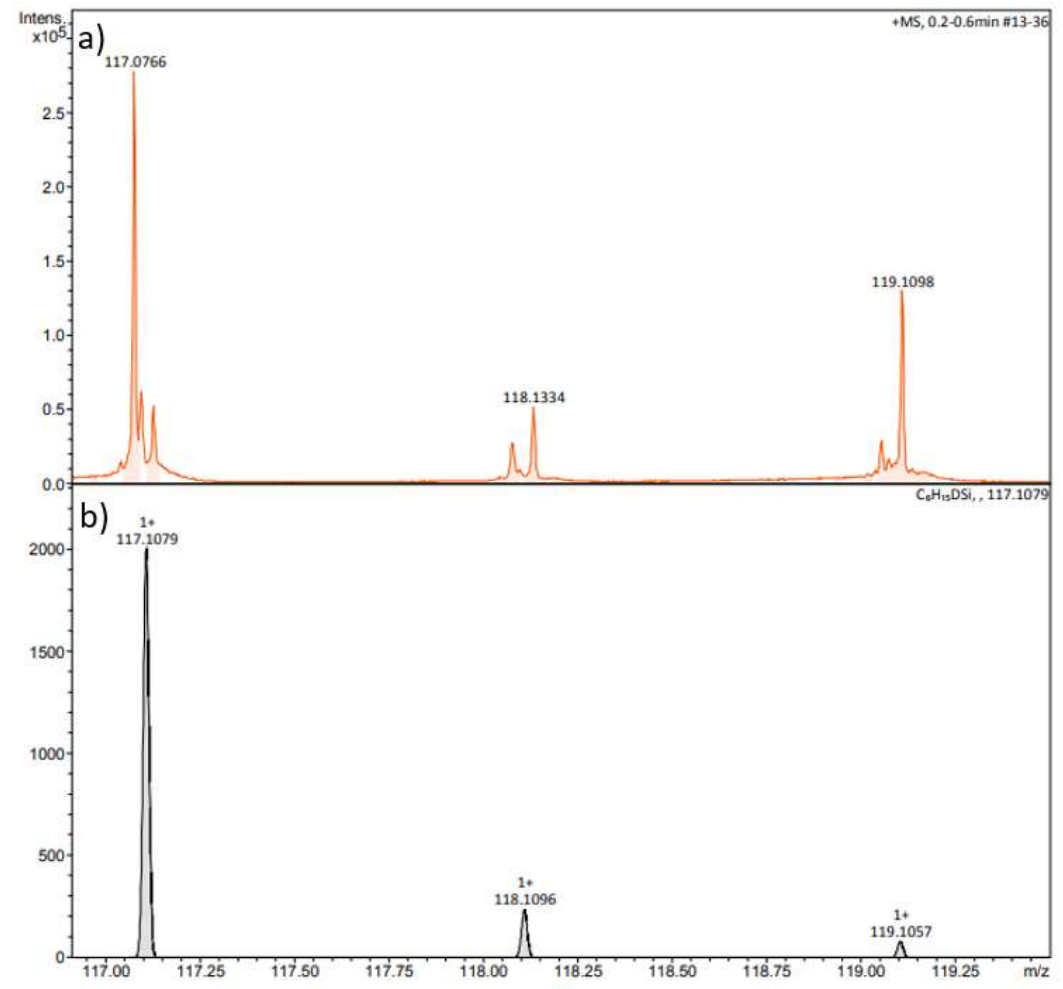

Figure S93. a) Measured and b) Simulated mass spectrum of Et $\mathbf{E}_{3}$ SiD.

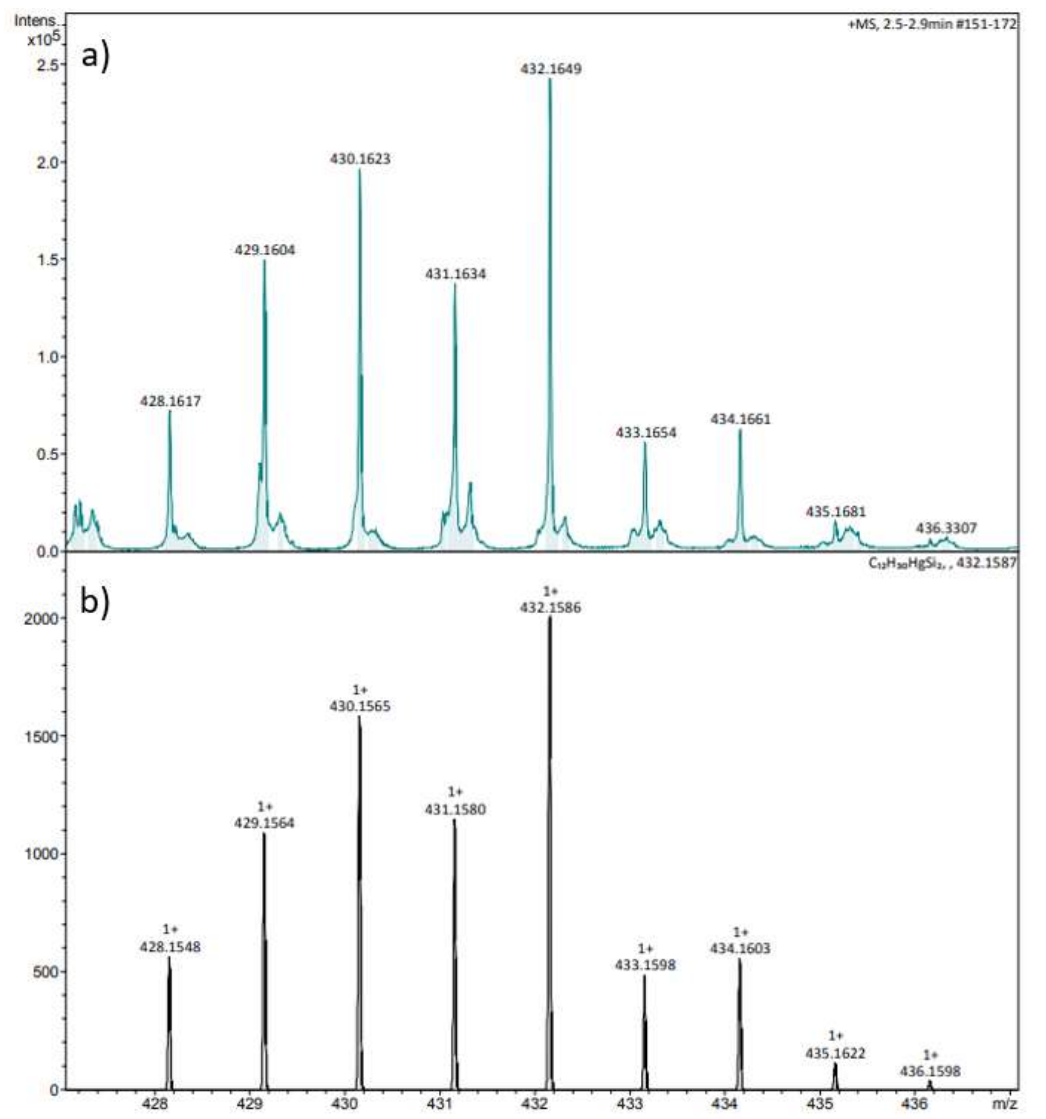

Figure S94. a) Measured and b) Simulated mass spectrum of ( $\left.{ }^{\mathbf{t}} \mathbf{B u M e} 2 \mathbf{S i}\right)_{2} \mathbf{H g}$. 


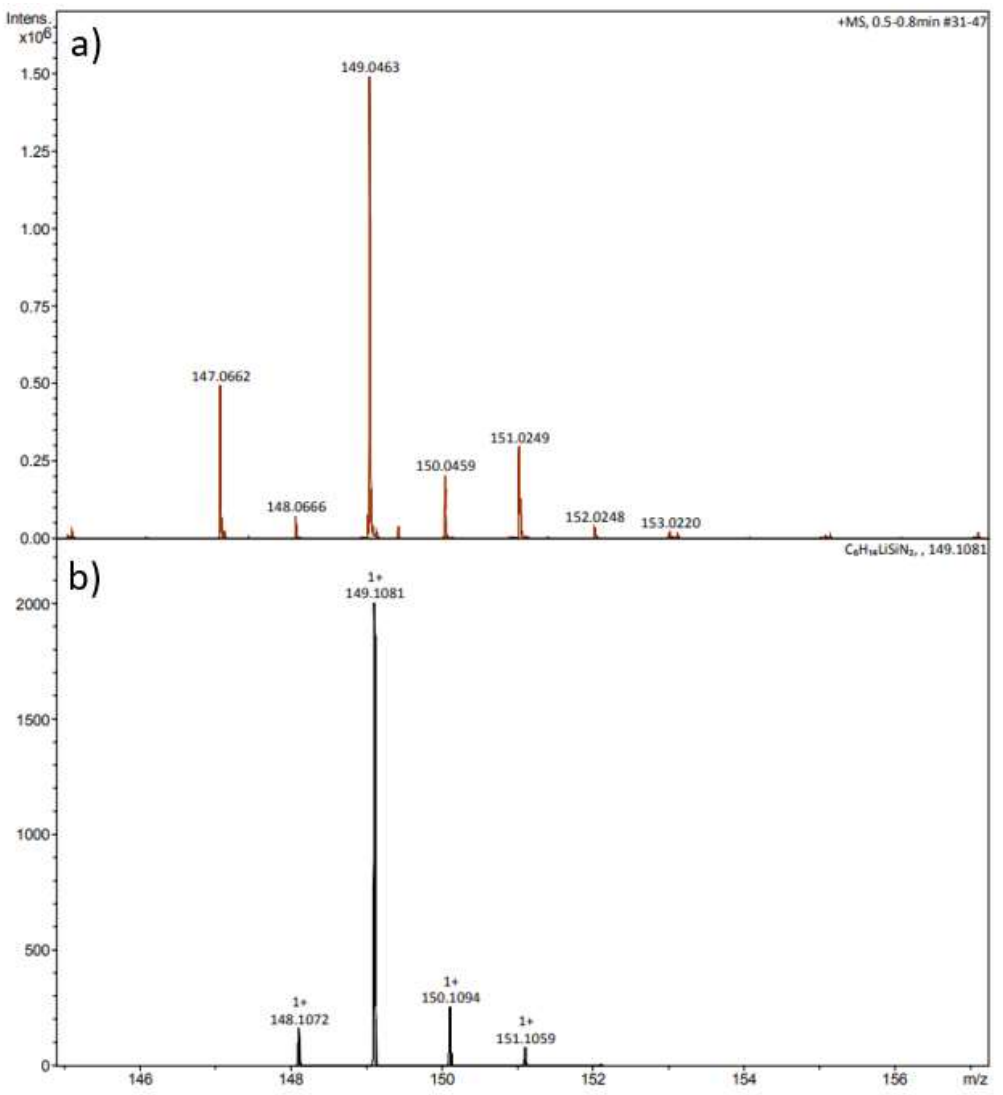

Figure S95. a) Measured and b) Simulated mass spectrum of ${ }^{\mathbf{t}} \mathbf{B u M e 2}$ SiLi.

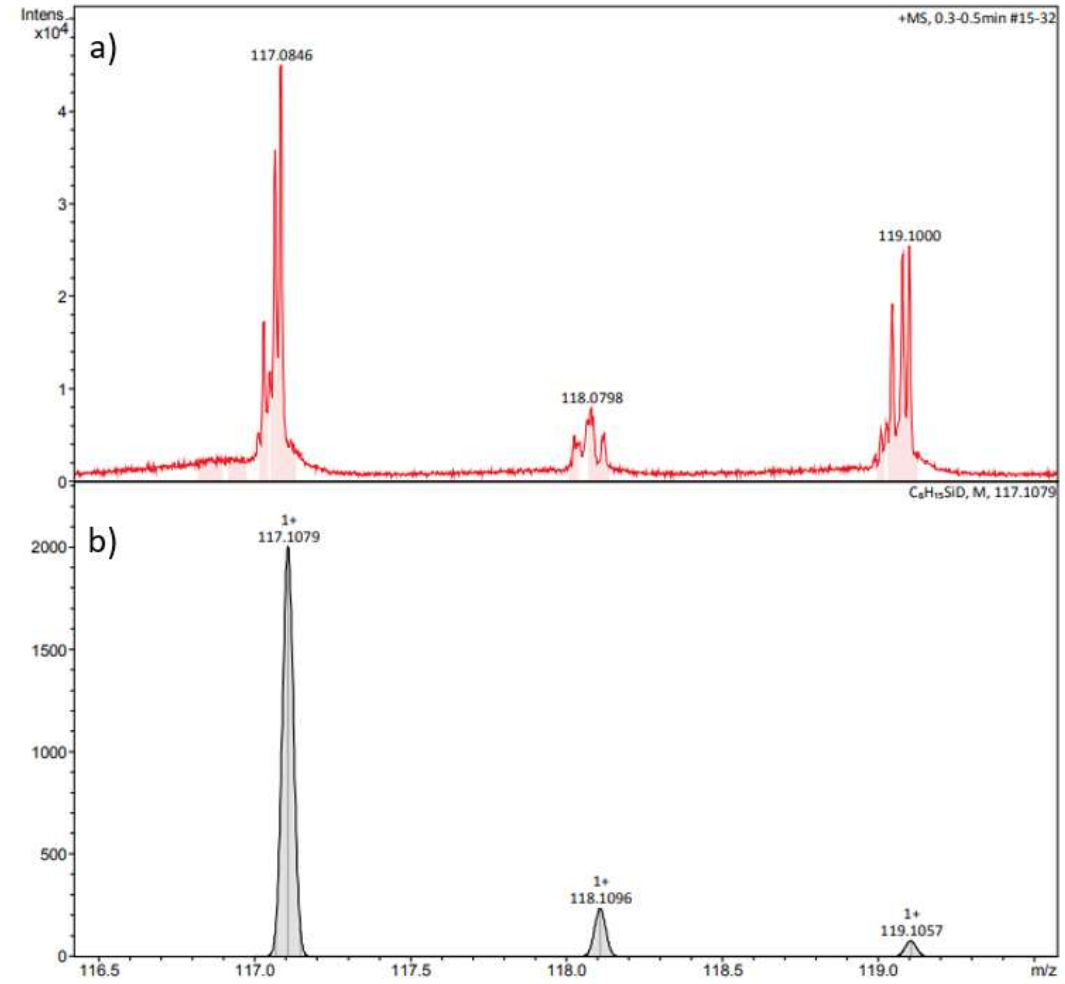

Figure S96. a) Measured and b) Simulated mass spectrum of ${ }^{\mathbf{t}} \mathbf{B u M e} \mathbf{M} \mathbf{S i D}$. 


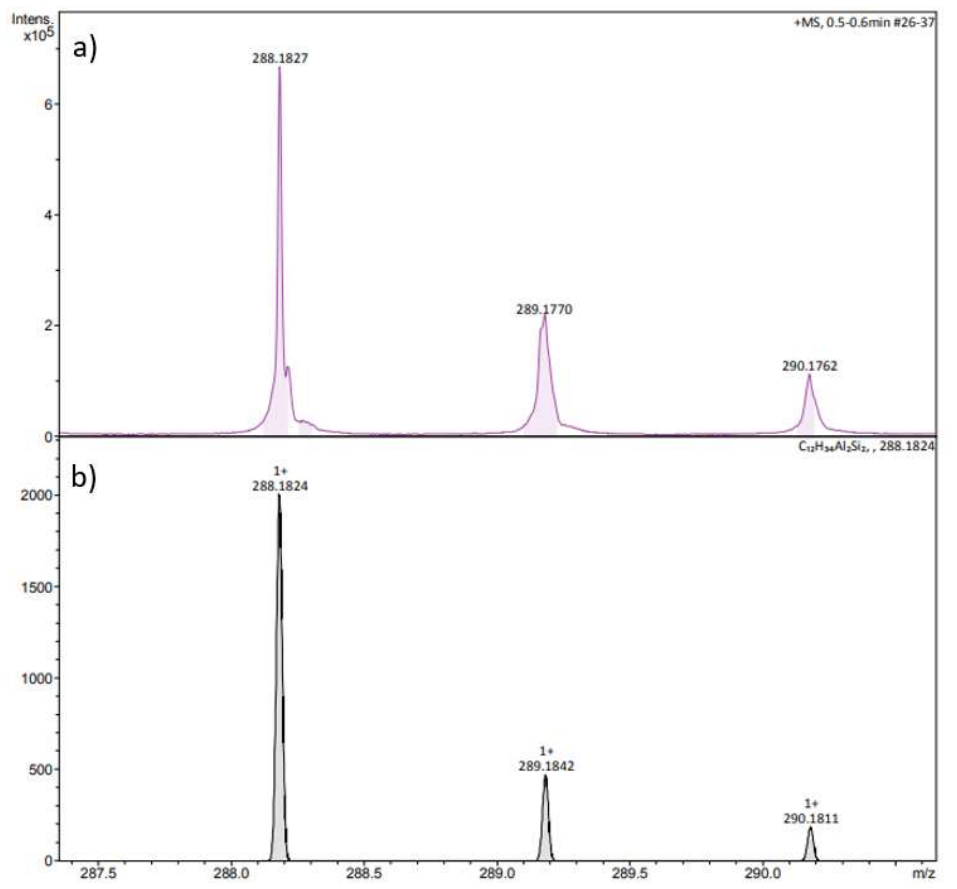

Figure S97. a) Measured and b) Simulated mass spectrum of $\left[\mathrm{Al}\left(\mathrm{SiEt}_{3}\right)_{2}(\mu-\mathrm{H}) \mathrm{AlH}_{3}\right]$.

\section{DFT Calculations}

All calculations were performed with the Gaussian 09 series of programs: Gaussian 09, Revision C.01, M. J. Frisch, G. W. Trucks, H. B. Schlegel, G. E. Scuseria, M. A. Robb, J. R. Cheeseman, G. Scalmani, V. Barone, B. Mennucci, G. A. Petersson, H. Nakatsuji, M. Caricato, X. Li, H. P. Hratchian, A. F. Izmaylov, J. Bloino, G. Zheng, J. L. Sonnenberg, M. Hada, M. Ehara, K. Toyota, R. Fukuda, J. Hasegawa, M. Ishida, T. Nakajima, Y. Honda, O. Kitao, H. Nakai, T. Vreven, J. A. Montgomery, Jr., J. E. Peralta, F. Ogliaro, M. Bearpark, J. J. Heyd, E. Brothers, K. N. Kudin, V. N. Staroverov, T. Keith, R. Kobayashi, J. Normand, K. Raghavachari, A. Rendell, J. C. Burant, S. S. Iyengar, J. Tomasi, M. Cossi, N. Rega, J. M. Millam, M. Klene, J. E. Knox, J. B. Cross, V. Bakken, C. Adamo, J. Jaramillo, R. Gomperts, R. E. Stratmann, O. Yazyev, A. J. Austin, R. Cammi, C. Pomelli, J. W. Ochterski, R. L. Martin, K. Morokuma, V. G. Zakrzewski, G. A. Voth, P. Salvador, J. J. Dannenberg, S. Dapprich, A. D. Daniels, O. Farkas, J. B. Foresman, J. V. Ortiz, J. Cioslowski, and D. J. Fox, Gaussian, Inc., Wallingford CT, 2010.

All calculations were performed using Density Functional Theory (DFT). ${ }^{16}$ Geometry optimizations and energy determinations were carried out at the M062 $\mathrm{X}^{17} / 6-31+\mathrm{G}(\mathrm{d}, \mathrm{p})$ level of theory. Frequency calculations were performed at the same level to validate each structure as a minimum (no imaginary frequencies). 
Calculations on the binding energy of intramolecular and intermolecular coordinated amine to mono-silyl aluminum complex

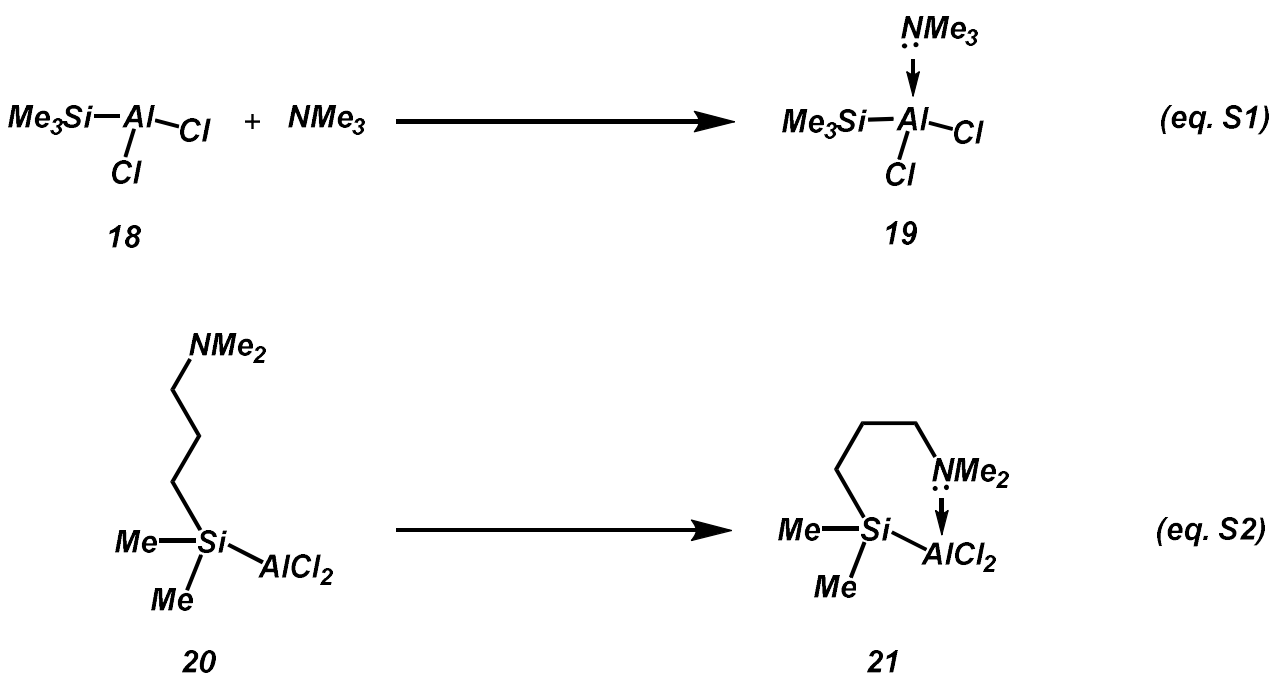

Table S3. Calculated binding energies $(\mathrm{kcal} / \mathrm{mol})$ of intramolecular and intermolecular coordinated amine to mono-silyl aluminum complex. ${ }^{\mathrm{a}, \mathrm{b}}$

\begin{tabular}{|c|c|c|c|}
\hline equation & $\Delta \mathrm{H}$ & $\mathrm{T} \Delta \mathrm{S}$ & $\Delta \mathrm{G}$ \\
\hline $\mathrm{S} 1$ & -39.93 & -14.24 & -25.69 \\
\hline $\mathrm{S} 2$ & -34.25 & -3.82 & -30.43 \\
\hline
\end{tabular}

a) Calculated at $\mathrm{M} 062 \mathrm{X} / 6-31+\mathrm{G}(\mathrm{d}, \mathrm{p})$ level of theory.

b) at $298.15 \mathrm{~K}, \mathrm{kcal} / \mathrm{mol}$.

Calculations on the binding energy of $\mathrm{Et}_{2} \mathrm{O}$ and $\mathrm{NMe}_{3}$ to (Me3 $\mathrm{Si}_{3} \mathrm{Al}$

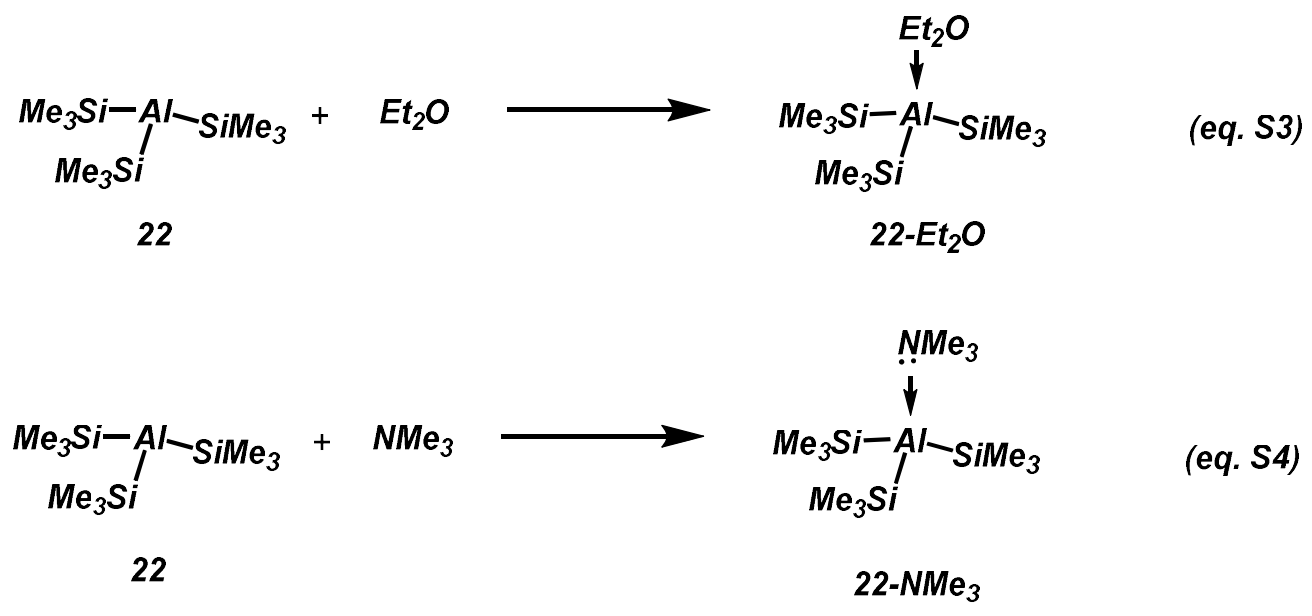


Table S4. Calculated binding energies ( $\mathrm{kcal} / \mathrm{mol})$ of $\mathrm{Et}_{2} \mathrm{O}$ and $\mathrm{NMe}_{3}$ to $\left(\mathrm{Me}_{3} \mathrm{Si}\right)_{3} \mathrm{Al}$. ${ }^{\mathrm{a}, \mathrm{b}}$

\begin{tabular}{|c|c|c|c|}
\hline equation & $\Delta \mathrm{H}$ & $\mathrm{T} \Delta \mathrm{S}$ & $\Delta \mathrm{G}$ \\
\hline $\mathrm{S} 3$ & -26.09 & -16.40 & -9.69 \\
\hline $\mathrm{S} 4$ & -35.88 & -16.69 & -19.19 \\
\hline
\end{tabular}

a) Calculated at M062X/6-31+G(d,p) level of theory.

b) at $298.15 \mathrm{~K}, \mathrm{kcal} / \mathrm{mol}$.

\section{Calculations on Al-C and Al-Si bond energies}

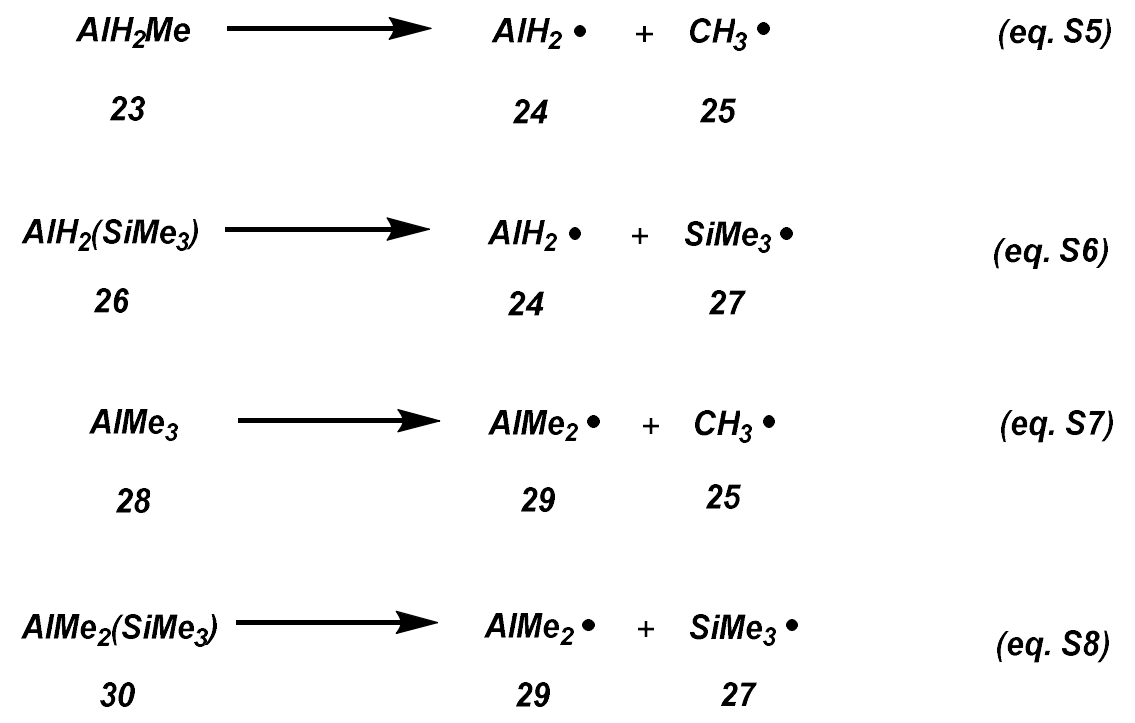

Table S5. Calculated energies $(\mathrm{kcal} / \mathrm{mol})$ for reactions shown in equations S5-S8., b

a) Calculated at $\mathrm{M} 062 \mathrm{X} / 6-31+\mathrm{G}(\mathrm{d}, \mathrm{p})$ level of theory.

\begin{tabular}{|c|c|c|c|}
\hline equation & $\Delta \mathrm{H}$ & $\mathrm{T} \Delta \mathrm{S}$ & $\Delta \mathrm{G}$ \\
\hline S5 & 80.16 & 9.92 & 70.24 \\
\hline S6 & 63.99 & 11.16 & 52.83 \\
\hline S7 & 79.26 & 14.34 & 64.92 \\
\hline S8 & 64.30 & 10.25 & 54.05 \\
\hline
\end{tabular}

b) at $298.15 \mathrm{~K}, \mathrm{kcal} / \mathrm{mol}$. 


\section{Optimized Cartesian coordinates for $\mathbf{1 8}$}

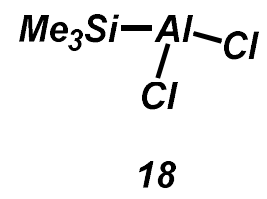

- Thermochemistry -

Temperature 298.15 Kelvin. Pressure 1.00 Atm.

Zero-point correction=

0.115781 (Hartree/Particle)

Thermal correction to Energy=

0.128233

Thermal correction to Enthalpy=

0.129177

Thermal correction to Gibbs Free Energy=

Sum of electronic and zero-point Energies=

0.074295

Sum of electronic and thermal Energies=

$-1571.927292$

Sum of electronic and thermal Enthalpies=

$-1571.914840$

$-1571.913896$

Sum of electronic and thermal Free Energies= $-1571.968778$

Number of imaginary frequencies $=0$

Charge $=0$ Multiplicity $=1$

$\begin{array}{lccc}\mathrm{Cl} & -2.076300000 & 1.759433000 & 0.000003000 \\ \mathrm{Cl} & -1.999693000 & -1.796899000 & 0.000003000 \\ \mathrm{Si} & 1.535948000 & 0.021035000 & 0.000002000 \\ \mathrm{Al} & -0.903231000 & 0.006210000 & 0.000010000 \\ \mathrm{C} & 2.161484000 & 1.800408000 & -0.000063000 \\ \mathrm{H} & 3.257123000 & 1.812655000 & -0.000100000 \\ \mathrm{H} & 1.817048000 & 2.345459000 & -0.883884000 \\ \mathrm{H} & 1.817110000 & 2.345495000 & 0.883761000 \\ \mathrm{C} & 2.157539000 & -0.884406000 & 1.537149000 \\ \mathrm{H} & 3.252486000 & -0.926120000 & 1.521277000 \\ \mathrm{H} & 1.855439000 & -0.377666000 & 2.458412000 \\ \mathrm{H} & 1.782322000 & -1.911511000 & 1.574342000 \\ \mathrm{C} & 2.157483000 & -0.884499000 & -1.537112000 \\ \mathrm{H} & 1.855336000 & -0.377820000 & -2.458394000 \\ \mathrm{H} & 3.252432000 & -0.926199000 & -1.521291000 \\ \mathrm{H} & 1.782277000 & -1.911611000 & -1.574227000\end{array}$

\section{Optimized Cartesian coordinates for $\mathrm{NMe}_{3}$}

- Thermochemistry -

Temperature 298.15 Kelvin. Pressure 1.00 Atm.

Zero-point correction= 0.121505 (Hartree/Particle)

Thermal correction to Energy=

0.126837

Thermal correction to Enthalpy=

0.127782

Thermal correction to Gibbs Free Energy=

0.094314 
Sum of electronic and zero-point Energies= Sum of electronic and thermal Energies= Sum of electronic and thermal Enthalpies= Sum of electronic and thermal Free Energies= Number of imaginary frequencies $=0$
$-174.268154$

$-174.262822$

$-174.261878$

$-174.295346$

Charge $=0$ Multiplicity $=1$

$\begin{array}{lrrr}\mathrm{N} & -0.000126000 & -0.000087000 & -0.386812000 \\ \mathrm{C} & -1.343108000 & -0.317255000 & 0.062567000 \\ \mathrm{H} & -1.639008000 & -1.298134000 & -0.320032000 \\ \mathrm{H} & -1.423985000 & -0.336329000 & 1.167090000 \\ \mathrm{H} & -2.046691000 & 0.427417000 & -0.320147000 \\ \mathrm{C} & 0.946352000 & -1.004290000 & 0.062616000 \\ \mathrm{H} & 1.004117000 & -1.063751000 & 1.167142000 \\ \mathrm{H} & 0.653294000 & -1.986446000 & -0.318908000 \\ \mathrm{H} & 1.943393000 & -0.770811000 & -0.321234000 \\ \mathrm{C} & 0.396776000 & 1.321582000 & 0.062596000 \\ \mathrm{H} & 1.392891000 & 1.559243000 & -0.321090000 \\ \mathrm{H} & -0.304906000 & 2.068664000 & -0.318926000 \\ \mathrm{H} & 0.421658000 & 1.400538000 & 1.167113000\end{array}$

\section{Optimized Cartesian coordinates for 19}<smiles>CN(C)[Al]([Mg])(Cl)Cl</smiles>

19

- Thermochemistry -

Temperature 298.15 Kelvin. Pressure 1.00Atm.

Zero-point correction=

Thermal correction to Energy=

Thermal correction to Enthalpy=

Thermal correction to Gibbs Free Energy=

Sum of electronic and zero-point Energies=

Sum of electronic and thermal Energies=

Sum of electronic and thermal Enthalpies=

Sum of electronic and thermal Free Energies=

Number of imaginary frequencies $=0$
0.240718 (Hartree/Particle)

0.259101

0.260045

\subsection{4}

$-1746.258729$

$-1746.240346$

$-1746.239402$

$-1746.305063$

Charge $=0$ Multiplicity $=1$
$\mathrm{Cl}$
1.099299000
$-1.583635000$
$-1.753928000$
$\mathrm{Cl} \quad 0.974796000$
$-1.498509000$
1.829140000
$\mathrm{Si} \quad-1.995471000$
0.144678000
$-0.027222000$ 


$\begin{array}{lrrr}\text { Al } & 0.347157000 & -0.555853000 & -0.011360000 \\ \mathrm{C} & -2.342168000 & 1.710172000 & -1.055598000 \\ \mathrm{H} & -3.419822000 & 1.910981000 & -1.060938000 \\ \mathrm{H} & -1.850259000 & 2.599975000 & -0.645046000 \\ \mathrm{H} & -2.022942000 & 1.592363000 & -2.096828000 \\ \mathrm{C} & -3.073289000 & -1.237194000 & -0.743786000 \\ \mathrm{H} & -4.127750000 & -0.938018000 & -0.740118000 \\ \mathrm{H} & -2.787463000 & -1.469051000 & -1.774487000 \\ \mathrm{H} & -2.981235000 & -2.156821000 & -0.157506000 \\ \mathrm{C} & -2.591031000 & 0.499914000 & 1.738832000 \\ \mathrm{H} & -2.059306000 & 1.344842000 & 2.190244000 \\ \mathrm{H} & -3.660506000 & 0.740059000 & 1.739422000 \\ \mathrm{H} & -2.436163000 & -0.369329000 & 2.385749000 \\ \mathrm{~N} & 1.566914000 & 1.078668000 & -0.009088000 \\ \mathrm{C} & 2.988838000 & 0.688382000 & 0.152906000 \\ \mathrm{H} & 3.265282000 & 0.010487000 & -0.657112000 \\ \mathrm{H} & 3.621022000 & 1.583888000 & 0.122611000 \\ \mathrm{H} & 3.113289000 & 0.176530000 & 1.108103000 \\ \mathrm{C} & 1.403608000 & 1.810849000 & -1.287358000 \\ \mathrm{H} & 2.003162000 & 2.728616000 & -1.268111000 \\ \mathrm{H} & 1.728281000 & 1.171948000 & -2.110101000 \\ \mathrm{H} & 0.350663000 & 2.067552000 & -1.426266000 \\ \mathrm{C} & 1.161561000 & 1.952939000 & 1.116182000 \\ \mathrm{H} & 0.121659000 & 2.260810000 & 0.976828000 \\ \mathrm{H} & 1.250852000 & 1.398676000 & 2.053087000 \\ \mathrm{H} & 1.801663000 & 2.842483000 & 1.147197000\end{array}$

\section{Optimized Cartesian coordinates for $\mathbf{2 0}$}

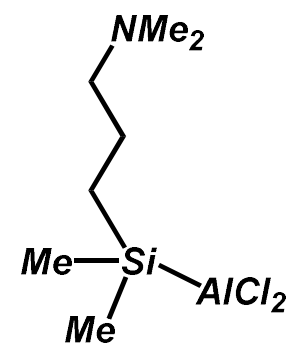

20

- Thermochemistry -

Temperature 298.15 Kelvin. Pressure 1.00 Atm.

Zero-point correction $=$

Thermal correction to Energy=

Thermal correction to Enthalpy=

Thermal correction to Gibbs Free Energy=

Sum of electronic and zero-point Energies=
0.247756 (Hartree/Particle)

0.266403

0.267347

0.198538

$-1784.291157$ 


\begin{tabular}{|c|c|c|c|}
\hline \multicolumn{4}{|c|}{ Sum of electronic and thermal Energies $=$} \\
\hline \multicolumn{4}{|c|}{ Sum of electronic and thermal Enthalpies= } \\
\hline \multirow{2}{*}{\multicolumn{4}{|c|}{$\begin{array}{l}\text { Sum of electronic and thermal Free Energies }= \\
\text { Number of imaginary frequencies }=0\end{array}$}} \\
\hline & & & \\
\hline \multicolumn{4}{|c|}{ Charge $=0$ Multiplicity $=1$} \\
\hline & 0.428646000 & 2.289175000 & -1.583202000 \\
\hline & 1.488706000 & 2.098721000 & 1.805714000 \\
\hline & 1.495156000 & -1.326060000 & \\
\hline $\mathrm{Al}$ & 1.151482000 & 1.073915000 & -0.01 \\
\hline $\mathrm{N}$ & -3.111062000 & -0.358856000 & \\
\hline & 0.155082000 & -2.149596000 & 531000 \\
\hline $\mathrm{H}$ & 0.417769000 & & 218000 \\
\hline I & 0.238068000 & -1.744192000 & 708000 \\
\hline & -1.292718000 & & \\
\hline $\mathrm{H}$ & -1.435894000 & -2.583054000 & -0.5 \\
\hline 1 & -1.969686000 & -2.453847000 & 027000 \\
\hline C & -1.690609000 & -0.56 & \\
\hline $\mathrm{H}$ & -1.326853000 & 36000 & 04000 \\
\hline $\mathrm{H}$ & -1.183801000 & 23000 & 11000 \\
\hline & -3.873403000 & 97000 & 19000 \\
\hline $\mathrm{H}$ & -4.935859000 & 798000 & 36000 \\
\hline & -3.569033000 & 493000 & 264000 \\
\hline $\mathrm{H}$ & & & \\
\hline & -3.348896000 & 0.940675000 & 309000 \\
\hline $\mathrm{H}$ & -2.821735000 & 1.005375000 & 6867000 \\
\hline $\mathrm{H}$ & -3.004587000 & 1.774328000 & 709000 \\
\hline $\mathrm{H}$ & -4.418775000 & 1.068817000 & -0.925416000 \\
\hline & 1.306762000 & -1.877230000 & 366000 \\
\hline & 1.378320000 & -2.968730000 & -2.078469000 \\
\hline $\mathrm{H}$ & 0.340127000 & -1.577208000 & -2.428489000 \\
\hline & 2.089357000 & -1.447210000 & -2.643389000 \\
\hline $\mathrm{C}$ & 3.183738000 & -1.833477000 & 0.459199000 \\
\hline & 3.282698000 & -2.924342000 & 0.432900000 \\
\hline H & 4.000941000 & -1.407347000 & -0.130060000 \\
\hline $\mathrm{H}$ & 3.308629000 & -1.507443000 & 1.496308000 \\
\hline
\end{tabular}

Optimized Cartesian coordinates for 21<smiles>CN1CCC[Si](C)(C)C1(Cl)Cl</smiles> 
- Thermochemistry -

Temperature 298.15 Kelvin. Pressure 1.00 Atm.

$\begin{array}{lc}\text { Zero-point correction }= & 0.250494 \text { (Hartree/Particle) } \\ \text { Thermal correction to Energy= } & 0.267794 \\ \text { Thermal correction to Enthalpy= } & 0.268738 \\ \text { Thermal correction to Gibbs Free Energy= } & 0.206021 \\ \text { Sum of electronic and zero-point Energies }= & -1784.344394 \\ \text { Sum of electronic and thermal Energies }= & -1784.327095 \\ \text { Sum of electronic and thermal Enthalpies }= & -1784.326150 \\ \text { Sum of electronic and thermal Free Energies }= & -1784.388868\end{array}$

Number of imaginary frequencies $=0$

Charge $=0$ Multiplicity $=1$

$\begin{array}{lccc}\mathrm{Cl} & -1.723091000 & -1.784831000 & 1.433020000 \\ \mathrm{Cl} & -1.085727000 & -1.193776000 & -2.048577000 \\ \mathrm{Si} & 1.866726000 & -0.362379000 & 0.167884000 \\ \mathrm{Al} & -0.510950000 & -0.750057000 & -0.014224000 \\ \mathrm{~N} & -1.220420000 & 1.155900000 & 0.169875000 \\ \mathrm{C} & 1.979953000 & 1.259919000 & -0.840310000 \\ \mathrm{H} & 3.004333000 & 1.650468000 & -0.773022000 \\ \mathrm{H} & 1.815337000 & 1.014219000 & -1.898999000 \\ \mathrm{C} & 0.999072000 & 2.369003000 & -0.425977000 \\ \mathrm{H} & 1.134147000 & 2.633227000 & 0.630442000 \\ \mathrm{H} & 1.235947000 & 3.285296000 & -0.980991000 \\ \mathrm{C} & -0.482443000 & 2.112564000 & -0.723417000 \\ \mathrm{H} & -1.025756000 & 3.066330000 & -0.660772000 \\ \mathrm{H} & -0.595399000 & 1.729627000 & -1.744103000 \\ \mathrm{C} & -1.108600000 & 1.570484000 & 1.588579000 \\ \mathrm{H} & -1.800407000 & 0.974699000 & 2.185437000 \\ \mathrm{H} & -1.352317000 & 2.635724000 & 1.686011000 \\ \mathrm{H} & -0.095524000 & 1.393591000 & 1.954680000 \\ \mathrm{C} & -2.655083000 & 1.192484000 & -0.216859000 \\ \mathrm{H} & -2.748650000 & 0.953766000 & -1.277212000 \\ \mathrm{H} & -3.063155000 & 2.191577000 & -0.022100000 \\ \mathrm{H} & -3.202261000 & 0.449319000 & 0.366937000 \\ \mathrm{C} & 2.589345000 & -0.027388000 & 1.891550000 \\ \mathrm{H} & 3.664424000 & 0.170767000 & 1.811525000 \\ \mathrm{H} & 2.131111000 & 0.837066000 & 2.383792000 \\ \mathrm{H} & 2.453736000 & -0.890896000 & 2.549939000 \\ \mathrm{C} & 2.959176000 & -1.644268000 & -0.690163000 \\ \mathrm{H} & 3.98586000 & -1.272824000 & -0.784367000 \\ \mathrm{H} & 2.989041000 & -2.580764000 & -0.125076000 \\ \mathrm{H} & 2.582030000 & -1.868889000 & -1.692666000\end{array}$

Optimized Cartesian coordinates for 22 


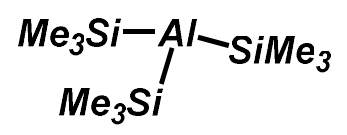

22

- Thermochemistry -

Temperature 298.15 Kelvin. Pressure 1.00 Atm.

Zero-point correction= 0.336639 (Hartree/Particle)

Thermal correction to Energy= 0.363234

Thermal correction to Enthalpy= 0.364178

Thermal correction to Gibbs Free Energy=

Sum of electronic and zero-point Energies=

0.276138

Sum of electronic and thermal Energies=

$-1469.556565$

Sum of electronic and thermal Enthalpies=

$-1469.529970$

Sum of electronic and thermal Free Energies=

$-1469.529025$

Number of imaginary frequencies $=0$

Charge $=0$ Multiplicity $=1$

$\begin{array}{lrrr}\mathrm{Al} & 0.003797000 & -0.006802000 & -0.095669000 \\ \mathrm{Si} & -0.438405000 & 2.419606000 & -0.023068000 \\ \mathrm{Si} & 2.327318000 & -0.833300000 & -0.023089000 \\ \mathrm{Si} & -1.886500000 & -1.590802000 & -0.024513000 \\ \mathrm{C} & 3.425746000 & 0.033105000 & -1.305599000 \\ \mathrm{H} & 3.433181000 & 1.116914000 & -1.150808000 \\ \mathrm{H} & 4.457949000 & -0.326780000 & -1.222058000 \\ \mathrm{H} & 3.087274000 & -0.158573000 & -2.328799000 \\ \mathrm{C} & 3.070355000 & -0.463243000 & 1.686599000 \\ \mathrm{H} & 4.111830000 & -0.803789000 & 1.723466000 \\ \mathrm{H} & 3.061682000 & 0.610296000 & 1.902542000 \\ \mathrm{H} & 2.524582000 & -0.973022000 & 2.487152000 \\ \mathrm{C} & 2.456962000 & -2.703713000 & -0.311139000 \\ \mathrm{H} & 1.867931000 & -3.260672000 & 0.425374000 \\ \mathrm{H} & 2.094181000 & -2.980626000 & -1.306353000 \\ \mathrm{H} & 3.498835000 & -3.034670000 & -0.228675000 \\ \mathrm{C} & -1.995446000 & -2.354751000 & 1.712488000 \\ \mathrm{H} & -2.821776000 & -3.074146000 & 1.753118000 \\ \mathrm{H} & -1.075181000 & -2.887355000 & 1.974296000 \\ \mathrm{H} & -2.176350000 & -1.595595000 & 2.480396000 \\ \mathrm{C} & -1.668229000 & -3.022664000 & -1.250524000 \\ \mathrm{H} & -0.743214000 & -3.573712000 & -1.052278000 \\ \mathrm{H} & -2.505322000 & -3.725182000 & -1.163174000 \\ \mathrm{H} & -1.634453000 & -2.670617000 & -2.286469000 \\ \mathrm{C} & -3.551990000 & -0.758007000 & -0.386777000 \\ \mathrm{H} & -4.371776000 & -1.480338000 & -0.297484000 \\ \mathrm{H} & -3.746477000 & 0.060189000 & 0.314974000 \\ \mathrm{H} & -3.579308000 & -0.342222000 & -1.399280000\end{array}$




$\begin{array}{lrrr}\mathrm{C} & -1.140990000 & 2.875770000 & 1.683075000 \\ \mathrm{H} & -1.363737000 & 3.948574000 & 1.721487000 \\ \mathrm{H} & -2.069665000 & 2.333733000 & 1.890560000 \\ \mathrm{H} & -0.433332000 & 2.653242000 & 2.488257000 \\ \mathrm{C} & -1.726756000 & 2.945666000 & -1.313386000 \\ \mathrm{H} & -2.671582000 & 2.411738000 & -1.168974000 \\ \mathrm{H} & -1.929456000 & 4.019625000 & -1.227015000 \\ \mathrm{H} & -1.383456000 & 2.752022000 & -2.334617000 \\ \mathrm{C} & 1.122133000 & 3.462494000 & -0.297995000 \\ \mathrm{H} & 1.898083000 & 3.217255000 & 0.435059000 \\ \mathrm{H} & 1.541719000 & 3.296654000 & -1.295610000 \\ \mathrm{H} & 0.893988000 & 4.530485000 & -0.202473000\end{array}$

\section{Optimized Cartesian coordinates for $\mathrm{Et}_{2} \mathrm{O}$}

- Thermochemistry -

Temperature 298.15 Kelvin. Pressure 1.00 Atm.

Zero-point correction=

Thermal correction to Energy=

Thermal correction to Enthalpy=

Thermal correction to Gibbs Free Energy=

Sum of electronic and zero-point Energies=

Sum of electronic and thermal Energies=

Sum of electronic and thermal Enthalpies=

Sum of electronic and thermal Free Energies=

Number of imaginary frequencies $=0$
0.137936 (Hartree/Particle)

0.144723

0.145667

0.107871

$-233.418187$

$-233.411400$

$-233.410456$

$-233.448251$

Charge $=0$ Multiplicity $=1$

$\begin{array}{lrrr}\mathrm{O} & 0.000000000 & -0.260905000 & -0.000090000 \\ \mathrm{C} & -1.175808000 & 0.519264000 & -0.000005000 \\ \mathrm{H} & -1.190274000 & 1.171108000 & -0.888543000 \\ \mathrm{H} & -1.190185000 & 1.171044000 & 0.888581000 \\ \mathrm{C} & 1.175808000 & 0.519264000 & 0.000072000 \\ \mathrm{H} & 1.190195000 & 1.170944000 & 0.888730000 \\ \mathrm{H} & 1.190264000 & 1.171208000 & -0.888393000 \\ \mathrm{C} & 2.370962000 & -0.412115000 & -0.000021000 \\ \mathrm{H} & 2.352542000 & -1.050981000 & -0.886450000 \\ \mathrm{H} & 3.302356000 & 0.160780000 & 0.000085000 \\ \mathrm{H} & 2.352490000 & -1.051222000 & 0.886234000 \\ \mathrm{C} & -2.370962000 & -0.412115000 & 0.000021000 \\ \mathrm{H} & -3.302356000 & 0.160779000 & 0.000023000 \\ \mathrm{H} & -2.352524000 & -1.051107000 & -0.886317000 \\ \mathrm{H} & -2.352508000 & -1.051095000 & 0.886367000\end{array}$

Optimized Cartesian coordinates for 22-Et $2 \mathrm{O}$ 
<smiles>CCO[C@H](C)[C@@H]([SiH3])CC</smiles>

\section{2- $\mathrm{Et}_{2} \mathrm{O}$}

- Thermochemistry -

Temperature 298.15 Kelvin. Pressure 1.00 Atm.

Zero-point correction $=$

Thermal correction to Energy=

Thermal correction to Enthalpy=
0.476530 (Hartree/Particle)

0.510393

0.511338

0.411634

$-1703.015867$

$-1702.982004$

$-1702.981060$

Sum of electronic and thermal Free Energies $=\quad-1703.080764$

Number of imaginary frequencies $=0$

Charge $=0$ Multiplicity $=1$

$\begin{array}{lrrr}\mathrm{Al} & 0.021536000 & -0.132170000 & 0.095766000 \\ \mathrm{O} & -0.122032000 & 0.329823000 & -1.842255000 \\ \mathrm{C} & -1.218686000 & 1.166822000 & -2.273912000 \\ \mathrm{H} & -0.800786000 & 2.070197000 & -2.731693000 \\ \mathrm{H} & -1.745992000 & 1.463471000 & -1.363088000 \\ \mathrm{C} & 1.033604000 & 0.326123000 & -2.706752000 \\ \mathrm{H} & 1.505196000 & -0.648666000 & -2.559307000 \\ \mathrm{H} & 0.673566000 & 0.381286000 & -3.739111000 \\ \mathrm{C} & -2.128887000 & 0.404023000 & -3.213740000 \\ \mathrm{H} & -2.975396000 & 1.034525000 & -3.499976000 \\ \mathrm{H} & -1.606303000 & 0.100924000 & -4.125332000 \\ \mathrm{H} & -2.514824000 & -0.490840000 & -2.718109000 \\ \mathrm{C} & 1.976581000 & 1.462441000 & -2.365924000 \\ \mathrm{H} & 2.854864000 & 1.423962000 & -3.016578000 \\ \mathrm{H} & 1.495219000 & 2.435844000 & -2.497941000 \\ \mathrm{H} & 2.313434000 & 1.376485000 & -1.328830000 \\ \mathrm{Si} & 1.939442000 & -1.674564000 & 0.250722000 \\ \mathrm{Si} & 0.369589000 & 2.046460000 & 1.215978000 \\ \mathrm{Si} & -2.211027000 & -1.054645000 & 0.598008000 \\ \mathrm{C} & 3.620390000 & -0.972291000 & -0.318828000 \\ \mathrm{H} & 3.853535000 & -0.027344000 & 0.184771000 \\ \mathrm{H} & 4.418558000 & -1.684786000 & -0.077879000 \\ \mathrm{H} & 3.658075000 & -0.793720000 & -1.399862000 \\ \mathrm{C} & 1.718555000 & -3.320146000 & -0.680283000 \\ \mathrm{H} & 2.573419000 & -3.982478000 & -0.498584000 \\ \mathrm{H} & 0.812101000 & -3.838979000 & -0.351215000\end{array}$




$\begin{array}{lrrr}\mathrm{H} & 1.636900000 & -3.171262000 & -1.763039000 \\ \mathrm{C} & 2.163380000 & -2.109427000 & 2.089522000 \\ \mathrm{H} & 2.995966000 & -2.810408000 & 2.221977000 \\ \mathrm{H} & 2.380267000 & -1.214538000 & 2.683403000 \\ \mathrm{H} & 1.262976000 & -2.573922000 & 2.505096000 \\ \mathrm{C} & -2.697784000 & -2.643882000 & -0.332818000 \\ \mathrm{H} & -2.699212000 & -2.509829000 & -1.419759000 \\ \mathrm{H} & -2.000904000 & -3.457152000 & -0.104605000 \\ \mathrm{H} & -3.701818000 & -2.968329000 & -0.034024000 \\ \mathrm{C} & -2.288943000 & -1.491101000 & 2.449513000 \\ \mathrm{H} & -3.282052000 & -1.877203000 & 2.708796000 \\ \mathrm{H} & -1.552928000 & -2.260160000 & 2.707835000 \\ \mathrm{H} & -2.091828000 & -0.616602000 & 3.078701000 \\ \mathrm{C} & -3.628402000 & 0.192708000 & 0.304135000 \\ \mathrm{H} & -3.805759000 & 0.379979000 & -0.761588000 \\ \mathrm{H} & -4.563926000 & -0.193553000 & 0.726285000 \\ \mathrm{H} & -3.418869000 & 1.155578000 & 0.785165000 \\ \mathrm{C} & -0.381100000 & 3.532691000 & 0.279714000 \\ \mathrm{H} & -1.468671000 & 3.435594000 & 0.182371000 \\ \mathrm{H} & -0.178793000 & 4.463814000 & 0.822536000 \\ \mathrm{H} & 0.039822000 & 3.639705000 & -0.726930000 \\ \mathrm{C} & -0.461496000 & 2.047969000 & 2.928100000 \\ \mathrm{H} & -0.281589000 & 2.997451000 & 3.446190000 \\ \mathrm{H} & -1.545433000 & 1.913177000 & 2.839116000 \\ \mathrm{H} & -0.078641000 & 1.240686000 & 3.562278000 \\ \mathrm{C} & 2.198289000 & 2.487470000 & 1.520911000 \\ \mathrm{H} & 2.704929000 & 1.693479000 & 2.080560000 \\ \mathrm{H} & 2.750450000 & 2.638978000 & 0.586562000 \\ \mathrm{H} & 2.275676000 & 3.412350000 & 2.105147000\end{array}$

\section{Optimized Cartesian coordinates for 22-NMe3<smiles>C[Al](C)(C)[Al](C)(C)C</smiles>

22-NMe 3

- Thermochemistry -

Temperature 298.15 Kelvin. Pressure 1.00 Atm.

$\begin{array}{lc}\text { Zero-point correction }= & 0.461397 \text { (Hartree/Particle) } \\ \text { Thermal correction to Energy= } & 0.493583 \\ \text { Thermal correction to Enthalpy= } & 0.494527 \\ \text { Thermal correction to Gibbs Free Energy= } & 0.399621 \\ \text { Sum of electronic and zero-point Energies }= & -1643.881218 \\ \text { Sum of electronic and thermal Energies }= & -1643.849032\end{array}$


Sum of electronic and thermal Enthalpies= Sum of electronic and thermal Free Energies= Number of imaginary frequencies $=0$

Charge $=0$ Multiplicity $=1$

$\begin{array}{lrrr}\mathrm{Al} & -0.001151000 & -0.000799000 & 0.115641000 \\ \mathrm{C} & -0.651287000 & 1.234781000 & 2.689103000 \\ \mathrm{H} & -0.727495000 & 1.215482000 & 3.784131000 \\ \mathrm{H} & -1.650329000 & 1.313881000 & 2.252753000 \\ \mathrm{C} & -0.741677000 & -1.178029000 & 2.692981000 \\ \mathrm{H} & -0.683160000 & -1.233066000 & 3.787904000 \\ \mathrm{H} & -1.787752000 & -1.098758000 & 2.389200000 \\ \mathrm{~N} & -0.000252000 & 0.001448000 & 2.199305000 \\ \mathrm{H} & -0.312483000 & -2.083341000 & 2.256081000 \\ \mathrm{H} & -0.060150000 & 2.100133000 & 2.381639000 \\ \mathrm{C} & 1.393204000 & -0.050102000 & 2.689671000 \\ \mathrm{H} & 1.846360000 & -0.996671000 & 2.387289000 \\ \mathrm{H} & 1.962438000 & 0.772662000 & 2.249422000 \\ \mathrm{H} & 1.413976000 & 0.031036000 & 3.784302000 \\ \mathrm{Si} & 0.767941000 & 2.242133000 & -0.557926000 \\ \mathrm{Si} & -2.327660000 & -0.457091000 & -0.556286000 \\ \mathrm{Si} & 1.559088000 & -1.786856000 & -0.555865000 \\ \mathrm{C} & 2.269563000 & 2.924642000 & 0.403468000 \\ \mathrm{H} & 3.110567000 & 2.222050000 & 0.379671000 \\ \mathrm{H} & 2.608834000 & 3.865933000 & -0.045253000 \\ \mathrm{H} & 2.034599000 & 3.133737000 & 1.454306000 \\ \mathrm{C} & -0.575870000 & 3.589031000 & -0.459617000 \\ \mathrm{H} & -0.196383000 & 4.545071000 & -0.839563000 \\ \mathrm{H} & -1.449323000 & 3.311947000 & -1.060226000 \\ \mathrm{H} & -0.922197000 & 3.752954000 & 0.567271000 \\ \mathrm{C} & 1.305975000 & 2.153570000 & -2.380489000 \\ \mathrm{H} & 1.609390000 & 3.141042000 & -2.747732000 \\ \mathrm{H} & 2.153270000 & 1.470772000 & -2.509202000 \\ \mathrm{H} & 0.490420000 & 1.793255000 & -3.017433000 \\ \mathrm{C} & -3.669512000 & 0.505810000 & 0.401135000 \\ \mathrm{H} & -3.481853000 & 1.585350000 & 0.372173000 \\ \mathrm{H} & -4.654286000 & 0.326392000 & -0.046709000 \\ \mathrm{H} & -3.732660000 & 0.202602000 & 1.453416000 \\ \mathrm{C} & -2.823217000 & -2.293972000 & -0.453721000 \\ \mathrm{H} & -3.840556000 & -2.443876000 & -0.834393000 \\ \mathrm{H} & -2.146071000 & -2.913379000 & -1.052307000 \\ \mathrm{H} & -2.793256000 & -2.673633000 & 0.574044000 \\ \mathrm{C} & -2.519061000 & 0.047581000 & -2.380381000 \\ \mathrm{H} & -3.525909000 & -0.183994000 & -2.747292000 \\ \mathrm{H} & -2.350950000 & 1.122246000 & -2.512130000 \\ \mathrm{H} & -1.799194000 & -0.480646000 & -3.015490000\end{array}$

$-1643.848088$

$-1643.942994$ 


$\begin{array}{llll}\mathrm{C} & 1.218092000 & -2.206956000 & -2.379534000 \\ \mathrm{H} & 1.923436000 & -2.962093000 & -2.745947000 \\ \mathrm{H} & 0.204011000 & -2.600721000 & -2.510810000 \\ \mathrm{H} & 1.313942000 & -1.319542000 & -3.015136000 \\ \mathrm{C} & 1.399431000 & -3.429854000 & 0.403351000 \\ \mathrm{H} & 2.047121000 & -4.192811000 & -0.044872000 \\ \mathrm{H} & 1.695522000 & -3.331809000 & 1.454963000 \\ \mathrm{H} & 0.371015000 & -3.808011000 & 0.376552000 \\ \mathrm{C} & 3.396758000 & -1.293947000 & -0.453584000 \\ \mathrm{H} & 3.592933000 & -0.397393000 & -1.052062000 \\ \mathrm{H} & 3.710444000 & -1.077768000 & 0.574119000 \\ \mathrm{H} & 4.036882000 & -2.098720000 & -0.834381000\end{array}$

\section{Optimized Cartesian coordinates for $\mathbf{2 3}$}

\section{$\mathrm{Al} \mathrm{H}_{2} \mathrm{Me}$}

\section{3}

- Thermochemistry -

Temperature 298.15 Kelvin. Pressure 1.00 Atm.

$\begin{array}{lc}\text { Zero-point correction }= & 0.048316 \text { (Hartree/Particle) } \\ \text { Thermal correction to Energy= } & 0.053036 \\ \text { Thermal correction to Enthalpy= } & 0.053980 \\ \text { Thermal correction to Gibbs Free Energy= } & 0.021595 \\ \text { Sum of electronic and zero-point Energies }= & -283.411278 \\ \text { Sum of electronic and thermal Energies }= & -283.406559 \\ \text { Sum of electronic and thermal Enthalpies }= & -283.405615 \\ \text { Sum of electronic and thermal Free Energies }= & -283.438000\end{array}$

Number of imaginary frequencies $=0$

Charge $=0$ Multiplicity $=1$

$\begin{array}{lrrr}\text { Al } & 0.004117000 & 0.716719000 & 0.000000000 \\ \text { H } & -0.010729000 & 1.520983000 & 1.365017000 \\ \text { H } & -0.010729000 & 1.520983000 & -1.365017000 \\ \text { C } & 0.004117000 & -1.239578000 & 0.000000000 \\ \text { H } & -1.030462000 & -1.607397000 & 0.000000000 \\ \text { H } & 0.486853000 & -1.657228000 & -0.888535000 \\ \text { H } & 0.486853000 & -1.657228000 & 0.888535000\end{array}$

\section{Optimized Cartesian coordinates for 24}

\section{$\mathrm{AlH}_{2} \bullet$}

\section{4}

- Thermochemistry -

Temperature 298.15 Kelvin. Pressure 1.00 Atm. 
Zero-point correction $=$

Thermal correction to Energy=

Thermal correction to Enthalpy=

Thermal correction to Gibbs Free Energy=

Sum of electronic and zero-point Energies=

Sum of electronic and thermal Energies $=$

Sum of electronic and thermal Enthalpies=

Sum of electronic and thermal Free Energies=

Number of imaginary frequencies $=0$

Charge $=0$ Multiplicity $=2$
Al
0.000000000
0.000000000
0.111332000
$\mathrm{H} \quad 0.000000000$
$-1.364015000$
$-0.723659000$
$\mathrm{H} \quad 0.000000000$
1.364015000
$-0.723659000$

0.014089

$$
-0.010164
$$

$-243.503771$

$-243.500851$

$-243.499907$

$-243.524161$

\section{Optimized Cartesian coordinates for 25}

\section{$\mathrm{CH}_{3} \cdot$ \\ 25}

- Thermochemistry -

Temperature 298.15 Kelvin. Pressure 1.00 Atm.

Zero-point correction $=$ 0.029836 (Hartree/Particle)

Thermal correction to Energy= 0.032987

Thermal correction to Enthalpy= 0.033931

Thermal correction to Gibbs Free Energy $=0.009985$

Sum of electronic and zero-point Energies= $-39.782059$

Sum of electronic and thermal Energies $=$ $-39.778908$

Sum of electronic and thermal Enthalpies= $-39.777964$

Sum of electronic and thermal Free Energies= $-39.801910$

Number of imaginary frequencies $=0$

Charge $=0$ Multiplicity $=2$

$\begin{array}{rrrr}\mathrm{C} & -0.000002000 & 0.000019000 & 0.000319000 \\ \mathrm{H} & 0.897384000 & 0.600885000 & -0.000638000 \\ \mathrm{H} & -0.969130000 & 0.476613000 & -0.000638000 \\ \mathrm{H} & 0.071756000 & -1.077614000 & -0.000638000\end{array}$

Optimized Cartesian coordinates for $\mathbf{2 6}$

\section{$\mathrm{AlH}_{2}\left(\mathrm{SiMe}_{3}\right)$}

26

- Thermochemistry - 
Temperature 298.15 Kelvin. Pressure 1.00 Atm.

$\begin{array}{lc}\text { Zero-point correction }= & 0.124934 \text { (Hartree/Particle) } \\ \text { Thermal correction to Energy }= & 0.135056 \\ \text { Thermal correction to Enthalpy= } & 0.136000 \\ \text { Thermal correction to Gibbs Free Energy }= & 0.090026 \\ \text { Sum of electronic and zero-point Energies }= & -652.601194 \\ \text { Sum of electronic and thermal Energies }= & -652.591072 \\ \text { Sum of electronic and thermal Enthalpies }= & -652.590128 \\ \text { Sum of electronic and thermal Free Energies }= & -652.636102\end{array}$

Number of imaginary frequencies $=0$

Charge $=0$ Multiplicity $=1$

$\begin{array}{lrrr}\mathrm{Al} & -2.125604000 & 0.011582000 & -0.011798000 \\ \mathrm{H} & -2.956458000 & 1.365757000 & 0.348622000 \\ \mathrm{H} & -2.951034000 & -1.350138000 & -0.337744000 \\ \mathrm{Si} & 0.336245000 & 0.000885000 & -0.011974000 \\ \mathrm{C} & 0.976382000 & -0.420123000 & 1.723311000 \\ \mathrm{H} & 2.072491000 & -0.425575000 & 1.723765000 \\ \mathrm{H} & 0.645776000 & 0.310224000 & 2.470044000 \\ \mathrm{H} & 0.641177000 & -1.412843000 & 2.049185000 \\ \mathrm{C} & 1.049332000 & 1.691866000 & -0.486441000 \\ \mathrm{H} & 2.144276000 & 1.671641000 & -0.423052000 \\ \mathrm{H} & 0.775808000 & 1.978662000 & -1.506076000 \\ \mathrm{H} & 0.68786000 & 2.478686000 & 0.191653000 \\ \mathrm{C} & 1.028836000 & -1.296095000 & -1.208488000 \\ \mathrm{H} & 0.760380000 & -1.077100000 & -2.244394000 \\ \mathrm{H} & 2.123186000 & -1.317192000 & -1.144016000 \\ \mathrm{H} & 0.659654000 & -2.293963000 & -0.967267000\end{array}$

\section{Optimized Cartesian coordinates for 27}

\section{$\mathrm{SiMe}_{3} \cdot$}

\section{7}

- Thermochemistry -

Temperature 298.15 Kelvin. Pressure 1.00 Atm.

Zero-point correction $=$

0.110437 (Hartree/Particle)

Thermal correction to Energy=

0.117886

Thermal correction to Enthalpy=

0.118831

Thermal correction to Gibbs Free Energy=

Sum of electronic and zero-point Energies=

0.079321

Sum of electronic and thermal Energies= $-408.996632$

Sum of electronic and thermal Enthalpies= $-408.989183$

Sum of electronic and thermal Free Energies= $-408.988238$ $-409.027748$

Number of imaginary frequencies $=0$ 


\begin{tabular}{lrrr}
\multicolumn{4}{l}{ Charge $=0$ Multiplicity $=2$} \\
$\mathrm{Si}$ & -0.000270000 & 0.000015000 & -0.439068000 \\
$\mathrm{C}$ & 0.895657000 & 1.543795000 & 0.182317000 \\
$\mathrm{H}$ & 0.905047000 & 1.558282000 & 1.279599000 \\
$\mathrm{H}$ & 1.933039000 & 1.568760000 & -0.163086000 \\
$\mathrm{H}$ & 0.402510000 & 2.457290000 & -0.161765000 \\
$\mathrm{C}$ & 0.889681000 & -1.547245000 & 0.182314000 \\
$\mathrm{H}$ & 1.927404000 & -1.575375000 & -0.161838000 \\
$\mathrm{H}$ & 0.897710000 & -1.562622000 & 1.279594000 \\
$\mathrm{H}$ & 0.393951000 & -2.458852000 & -0.163061000 \\
$\mathrm{C}$ & -1.785112000 & 0.003449000 & 0.182422000 \\
$\mathrm{H}$ & -2.326731000 & 0.887975000 & -0.164443000 \\
$\mathrm{H}$ & -2.328268000 & -0.881843000 & -0.160079000 \\
$\mathrm{H}$ & -1.802246000 & 0.006183000 & 1.279710000
\end{tabular}

\section{Optimized Cartesian coordinates for $\mathbf{2 8}$}

\section{$\mathrm{AlMe}_{3}$}

28

- Thermochemistry -

Temperature 298.15 Kelvin. Pressure 1.00 Atm.

Zero-point correction=

Thermal correction to Energy=

Thermal correction to Enthalpy=

Thermal correction to Gibbs Free Energy=

Sum of electronic and zero-point Energies=

Sum of electronic and thermal Energies=

Sum of electronic and thermal Enthalpies=

Sum of electronic and thermal Free Energies=

Number of imaginary frequencies $=0$
0.107497 (Hartree/Particle)

0.114285

0.115229

0.078010

$-361.975053$

$-361.968265$

$-361.967321$

$-362.004540$

Charge $=0$ Multiplicity $=1$

$\begin{array}{lccc}\text { Al } & -0.000237000 & -0.000237000 & -0.003933000 \\ \mathrm{C} & -1.866255000 & -0.611026000 & -0.012805000 \\ \mathrm{H} & -2.441620000 & -0.137973000 & 0.798538000 \\ \mathrm{H} & -2.361048000 & -0.323367000 & -0.948244000 \\ \mathrm{H} & -1.965108000 & -1.700584000 & 0.091927000 \\ \mathrm{C} & 1.462542000 & -1.309801000 & -0.003963000 \\ \mathrm{H} & 2.459990000 & -0.854149000 & -0.258636000 \\ \mathrm{H} & 1.545044000 & -1.790166000 & 1.021789000 \\ \mathrm{H} & 1.245139000 & -2.148936000 & -0.739288000 \\ \mathrm{C} & 0.403993000 & 1.921049000 & 0.018307000 \\ \mathrm{H} & 0.813695000 & 2.219933000 & 1.012757000 \\ \mathrm{H} & 1.189134000 & 2.170701000 & -0.740552000\end{array}$


$\mathrm{H} \quad-0.488831000 \quad 2.551290000 \quad-0.176394000$

\section{Optimized Cartesian coordinates for 29}

\section{$\mathrm{AlMe}_{2} \cdot$}

29

- Thermochemistry -

Temperature 298.15 Kelvin. Pressure 1.00 Atm.

$\begin{array}{lc}\text { Zero-point correction }= & 0.070503 \text { (Hartree/Particle) } \\ \text { Thermal correction to Energy= } & 0.076470 \\ \text { Thermal correction to Enthalpy= } & 0.077414 \\ \text { Thermal correction to Gibbs Free Energy= } & 0.041286 \\ \text { Sum of electronic and zero-point Energies }= & -322.069960 \\ \text { Sum of electronic and thermal Energies }= & -322.063993 \\ \text { Sum of electronic and thermal Enthalpies }= & -322.063049 \\ \text { Sum of electronic and thermal Free Energies }= & -322.099177\end{array}$

Number of imaginary frequencies $=0$

Charge $=0$ Multiplicity $=2$

$\begin{array}{lrrr}\text { Al } & 0.000001000 & 0.650163000 & 0.000003000 \\ \text { C } & -1.681605000 & -0.392118000 & -0.000007000 \\ \text { H } & -2.589097000 & 0.215776000 & -0.000410000 \\ \text { H } & -1.706891000 & -1.044887000 & -0.882160000 \\ \text { H } & -1.707267000 & -1.044232000 & 0.882622000 \\ \mathrm{C} & 1.681607000 & -0.392118000 & 0.000012000 \\ \mathrm{H} & 2.589112000 & 0.215755000 & 0.000571000 \\ \mathrm{H} & 1.706814000 & -1.045050000 & 0.882045000 \\ \mathrm{H} & 1.707302000 & -1.044070000 & -0.882737000\end{array}$

\section{Optimized Cartesian coordinates for $\mathbf{3 0}$}

\section{$\mathrm{AlMe}_{2}\left(\mathrm{SiMe}_{3}\right)$}

\section{0}

- Thermochemistry -

Temperature 298.15 Kelvin. Pressure 1.00 Atm.

Zero-point correction=

0.183049 (Hartree/Particle)

Thermal correction to Energy=

0.197768

Thermal correction to Enthalpy=

0.198712

Thermal correction to Gibbs Free Energy=

Sum of electronic and zero-point Energies=

0.139411

Sum of electronic and thermal Energies=

$-731.169425$

Sum of electronic and thermal Enthalpies=

$-731.154706$

$-731.153762$

Sum of electronic and thermal Free Energies=

$-731.213062$ 
Number of imaginary frequencies $=0$

\begin{tabular}{lccc}
\multicolumn{4}{l}{ Charge $=0$ Multiplicity $=1$} \\
Al & -1.427119000 & 0.003299000 & 0.015548000 \\
Si & 1.040814000 & 0.004886000 & -0.005411000 \\
$\mathrm{C}$ & 1.749477000 & -0.103718000 & 1.755835000 \\
$\mathrm{H}$ & 2.845019000 & -0.110436000 & 1.714248000 \\
$\mathrm{H}$ & 1.444774000 & 0.749327000 & 2.370481000 \\
$\mathrm{H}$ & 1.429821000 & -1.018597000 & 2.265111000 \\
$\mathrm{C}$ & 1.743840000 & 1.582628000 & -0.793036000 \\
$\mathrm{H}$ & 2.839584000 & 1.566752000 & -0.766519000 \\
$\mathrm{H}$ & 1.435523000 & 1.682986000 & -1.838777000 \\
$\mathrm{H}$ & 1.407169000 & 2.477333000 & -0.259172000 \\
$\mathrm{C}$ & 1.724055000 & -1.481766000 & -0.968678000 \\
$\mathrm{H}$ & 1.432787000 & -1.448010000 & -2.023576000 \\
$\mathrm{H}$ & 2.819275000 & -1.495109000 & -0.924525000 \\
$\mathrm{H}$ & 1.358832000 & -2.426328000 & -0.552251000 \\
$\mathrm{C}$ & -2.389826000 & -1.713900000 & 0.001066000 \\
$\mathrm{H}$ & -3.462502000 & -1.609003000 & 0.190702000 \\
$\mathrm{H}$ & -2.273366000 & -2.198693000 & -0.977297000 \\
$\mathrm{H}$ & -1.979403000 & -2.414592000 & 0.737407000 \\
$\mathrm{C}$ & -2.413385000 & 1.706806000 & 0.001983000 \\
$\mathrm{H}$ & -2.302706000 & 2.194986000 & -0.975317000 \\
$\mathrm{H}$ & -3.484648000 & 1.585859000 & 0.190038000 \\
$\mathrm{H}$ & -2.013976000 & 2.411938000 & 0.740060000
\end{tabular}

\section{References}

1) Armarego, W. L. F.; Chai, C., Purification of Laboratory Chemicals. ButterworthHeinemann: 2009.

2) Fulmer, G. R.; Miller, A. J. M.; Sherden, N. H.; Gottlieb, H. E.; Nudelman, A.; Stoltz, B. M.; Bercaw, J. E.; Goldberg, K. I., NMR Chemical Shifts of Trace Impurities: Common Laboratory Solvents, Organics, and Gases in Deuterated Solvents Relevant to the Organometallic Chemist. Organometallics 2010, 29 (9), 2176-2179.

3) Schraml, J., ${ }^{29} \mathrm{Si}$ NMR spectroscopy of trimethylsilyl tags. Prog. Nucl. Magn. Reson. Spectrosc. 1990, 22 (4), 289-348.

4) Morris, G. A.; Freeman, R., Enhancement of nuclear magnetic resonance signals by polarization transfer. J. Am. Chem. Soc. 1979, 101 (3), 760-762.

5) Helmer, B. J.; West, R., Enhancement of silicon-29 NMR signals by proton polarization transfer. Organometallics 1982, 1 (6), 877-879.

6) Akitt, J. W., Multinuclear studies of aluminium compounds. Progress in Nuclear Magnetic Resonance Spectroscopy 1989, 21 (1), 1-149.

7) Martineau, C.; Taulelle, F.; Haouas, M., The Use of ${ }^{27}$ Al NMR to Study Aluminum Compounds: A Survey of the Last 25 Years. . Rappoport, Z., Ed. 2016. 
8) a) Awad, H.; Khamis, M. M.; El-Aneed, A., Mass Spectrometry, Review of the Basics: Ionization. Applied Spectroscopy Reviews 2015, 50 (2), 158-175; b) Liu, D. Q.; Sun, M., Formation of the Ions of Methylindoles in APCI Mass Spectrometry. ISRN Spectroscopy 2012, 2012, 973649.

9) Neumann, W. P.; Blaukat, U., Preparation of the Compounds R ${ }_{3} \mathrm{El}_{-} \mathrm{Hg}-\mathrm{ElR}_{3}(\mathrm{El}=\mathrm{C}$, $\mathrm{Si}, \mathrm{Ge}, \mathrm{Sn})$ and their Synthetic Applications. Angewandte Chemie International Edition in English 1969, 8 (8), 611-612.

10) Bernhoft, R. A., Mercury toxicity and treatment: a review of the literature. $J$ Environ Public Health 2012, 2012, 460508-460508.

11) Mashin, E.; Kratish, Y.; Kaushansky, A.; Bravo-Zhivotovskii, D.; Apeloig, Y., Synthesis by $\mathrm{Si}-\mathrm{H}$ bond lithiation of novel half-pincer and pincer silyllithium compounds and their molecular structures. Struct. Chem. 2017, 28 (2), 537-544.

12) Sheldrick, G., SHELXT - Integrated space-group and crystal-structure determination. Acta Crystallographica Section A 2015, 71 (1), 3-8.

13) Dolomanov, O. V.; Bourhis, L. J.; Gildea, R. J.; Howard, J. A. K.; Puschmann, H., OLEX2: a complete structure solution, refinement and analysis program. Journal of Applied Crystallography 2009, 42 (2), 339-341.

14) Bourhis, L. J.; Dolomanov, O. V.; Gildea, R. J.; Howard, J. A. K.; Puschmann, H., The anatomy of a comprehensive constrained, restrained refinement program for the modern computing environment - Olex2 dissected. Acta Crystallographica Section A 2015, $71(1), 59-75$.

15) Mercury Software from CCDC: $\underline{\text { http://www.ccdc.cam.ac.uk/ }}$

Solutions/CSDSystem/Pages/Mercury.aspx.

16) W. Koch, M. C. Holthausen, A Chemist's Guide to Density Functional Theory, 2nd ed., Wiley, 2001.

17) Zhao, Y.; Truhlar, D. G., The M06 suite of density functionals for main group thermochemistry, thermochemical kinetics, noncovalent interactions, excited states, and transition elements: two new functionals and systematic testing of four M06-class functionals and 12 other functionals. Theor. Chem. Acc. 2008, 120 (1), 215-241. 